


\title{
Revista do Museu de ARQueologia e EtNologia
}

\author{
Comissão Editorial \\ Elaine Farias Veloso Hirata \\ Maria Beatriz Borba Florenzano \\ Maria Isabel D'Agostino Fleming \\ Marisa Coutinho Afonso
}

\section{Editora Responsável}

Maria Isabel D'Agostino Fleming

\section{Conselho Editorial}

Ana Mae Tavares Barbosa
Antonio Porro
Augusto Titarelli
Aziz N. Ab'Saber
Carlos Serrano
Fábio Leite
Felipe Tirado Segura
Gabriela Martin D'Ávila
Igor Chmyz
Jacyntho Lins Brandão
José Antonio Dabdab Trabulsi
Kabengele Munanga

Ana Mae Tavares Barbosa

Lux Vidal

Maria Luiza Corassin

Maria Manuela Carneiro da Cunha

Maria Margareth Lopes

Niède Guidon

Noberto Luiz Guarinello

Oscar Landmann

Pedro Ignácio Schmitz

Pedro Paulo Abreu Funari

Roberto Cardoso de Oliveira

Rudolf Winkes

Solange Godoy 




\section{REVISTA DO MUSEU}

$\mathrm{DE}$

\section{ARQUEOLOGIA E ETNOLOGIA}

\section{UNIVERSIDADE DE SÃO PAULO}

Formas Arquitetônicas Clássicas em Edifícios Religiosos do Período Bizantino

Regina Helena Rezende

Suplemento 5

2008

São Paulo 



\section{Agradecimentos}

À Profa. Dra. Maria Beatriz Borba Florenzano, por diversos motivos. Por ter incentivado essa idéia quando ela era apenas uma vontade incerta de se estudar a arqueologia clássica. Pelo apoio e motivação, que faziam com que eu saísse de cada reunião com a vontade de fazer cada vez melhor. Pela disposição em ouvir, questionar e ensinar, sempre instigando minha curiosidade e me motivando a fazer um bom trabalho. Enfim, pela confiança depositada em mim.

Aos professores doutores Maria Isabel Fleming e Paulo César Garcez Marins pela presença em duas etapas importantes desse trabalho: as bancas do exame de qualificação e a da defesa da dissertação de mestrado. Agradeço a ambos pela leitura atenciosa, os comentários enriquecedores, as críticas construtivas e as indicações bibliográficas, responsáveis pela realização de um trabalho de melhor qualidade. As sugestões da profa. Dra. Maria Isabel, assim como a leitura de livros que ela me emprestou, ampliaram meu entendimento a respeito do Império Romano na época do surgimento do cristianismo. Ao prof. Dr. Paulo César, que entendeu tão bem a forma como eu compreendo a arquitetura, sou grata pelos comentários e sugestões que abriram os meus olhos para uma interpretação da arte que vai além da sua forma.

A CAPES, que forneceu os subsídios financeiros para a realização dessa pesquisa.

À Profa. Dra. Haiganuch Sarian, que me acolheu como sua monitora no curso de graduação que ministrou em 2004, pelas conversas e sugestões bibliográficas a respeito da arquitetura clássica.

À profa. Dra. Elaine Hirata pelas proveitosas discussões sobre questões metodológicas e o comportamento religioso de sociedades na Antiguidade durante a disciplina de pós-graduação cursada em 2003.

A todos os integrantes do grupo de pesquisa "A cidade e seu território no Mediterrâneo Antigo" e ao Labeca - Laboratório de estudos sobre a cidade antiga, por me propiciarem um ambiente de discussão em grupo que foi essencial para uma compreensão mais sólida das questões a respeito da cidade na Antiguidade.

Ao Prof. Dr. Francisco Marshall e à toda equipe que participou da Expedição Apollonia em setembro de 2003. A viagem à Israel foi uma experiência importante para a minha formação na área, tanto pela possibilidade de participar de uma escavação fora do Brasil, no sítio arqueológico de Apollonia-Arsuf, quanto pelas cidades por onde passamos, tais como Cesarea, Beth Shean e Tiberias, onde tivemos contato com edifícios e cidades de época helenística e romana, e Jerusalém, onde tive a possibilidade de visitar a Igreja do Santo Sepulcro, entre outras, e a oportunidade de conhecer a importância dessa cidade e do seu passado, não apenas para o cristianismo, mas também para o judaísmo e o islamismo.

À equipe da divisão educativa do MAE, onde realizei o estágio de licenciatura em História, pelas entusiasmadas lições a respeito da educação patrimonial e as visitas ao nosso Museu, onde sob sua orientação pude ver as peças do acervo sob uma nova ótica.

Aos funcionários da seção acadêmica e da biblioteca do MAE, pela eficiência e dedicação.

Aos amigos que fiz dentro do museu e fora dele durante os anos dedicados ao mestrado, com quem assisti às aulas, encontrei na biblioteca e pelos corredores do MAE, e que generosamente dividiram comigo seu conhecimento. Aos amigos de tantos anos, onde sempre encontro conforto e apoio.

À minha família e àqueles que se envolveram intensamente com as minhas tarefas, pelo uso do scanner, pelo auxílio na elaboração do banco de dados e no tratamento das imagens, pela leitura e sugestões de uma melhor redação nas muitas versões pela qual esse texto passou até a sua configuração final. Agradeço pelo suporte tecnológico, intelectual e emocional, que me deram a força e o equilíbrio necessários para a realização desse trabalho. 



\section{Resumo}

Este trabalho tem como objetivo a identificação e o estudo da permanência de formas arquitetônicas greco-romanas, ditas clássicas, nas primeiras igrejas cristãs, em uma fase inicial do seu estabelecimento na região da Palestina, desde o governo de Constantino, na primeira metade do século IV d.C., até o final do século VI d.C. Nesse intervalo de quase três séculos procuramos identificar as formas arquitetônicas essenciais que serão constitutivas das igrejas cristãs em seu momento inicial de organização e estudar de que maneira elementos da cultura clássica foram recuperados e usados nesses espaços. Buscamos ir além da análise estritamente material desses edifícios, que evidenciam em suas formas idéias e valores antigos em contraposição a novos elementos adotados nesse momento de mudança, produtos concretos de uma nova cultura que se configura nessa época, conhecida como Período Bizantino.

Palavras-chave: arquitetura, igrejas paleocristãs, Antiguidade Tardia, Período Bizantino, comunicação não-verbal.

\section{Abstract}

The goal of this dissertation is to identify and study the Graeco-roman architectural forms -known as classical forms - that were preserved in early Christian churches built in the Palestinian area. The chronological scope is from the first half of the IV century, under Constantine's rule, to the end of the VI century AD. Studying this period of three centuries, we tried to recognize which basic architectural shapes had been part of early Christian churches and which classical shapes were recovered and preserved in this area. We tried to go beyond the material analysis of this buildings, looking for ancient ideas and values still in use in this age of transformation, called Byzantine Period, when new concepts of an arising culture were starting to achieve material forms.

Keywords: architecture, early Christian churches, Late Antiquity, Byzantine Period, non-verbal communication. 



\section{ÍNDICE}

INTRODUÇÃo

CAPítulo I

ARQUITETURA E SOCIEDADE - ALGUMAS VERTENTES INTERPRETATIVAS

Arqueologia

Arquitetura

História da Arte

Contribuições das disciplinas para o estudo das igrejas paleocristãs

CApítulo 2

O ESTABELECIMENTO DO CRISTIANISMO NO IMPÉRIO ROMANO

Mecanismos de organização do Império Romano - as cidades

A arquitetura romana e suas técnicas construtivas nas colônias do Império

O surgimento do cristianismo

O Império Romano no Período Bizantino - Constantino e o cristianismo

Arte e arquitetura no período bizantino

Capítulo 3

CATÁLOGO DE IGREJAS

Mapa de localização das igrejas

Relação dos locais que constam no mapa

Catálogo de Igrejas paleocristãs na Palestina

Gráficos e tabelas

CAPítulo 4

CONSIDERAÇÕES SOBRE A PERMANÊNCIA de ELEMENTOS CLÁSSICOS NAS IGREJAS

PALEOCRISTÃS

Capítulo 5

CONCLUSÃO

GLOSSÁRIO

BIBLIOGRAFIA

Abreviações

Fontes

Referências bibliográficas

Internet 



\section{ÍNDICE DE Figuras}

Capa - Reconstituição isométrica da Igreja da Natividade, Belém. Fonte: Tsafrir, Y. Ancient Churches Revealed, p. 7.

Fig. 1 - Mapa geral do Império Romano na $2^{2}$ metade do século I d.C., com a localização das

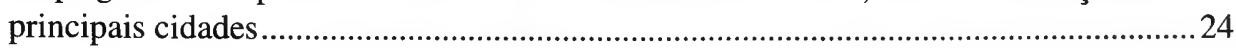

Fig. 2 - Planta da Basílica Aemilia, em Roma, reconstruída depois de 14 a. C. ..........................30

Fig. 3 - Planta da Basílica Júlia, em Roma, reconstruída entre 12 a.C. e 12 d.C. .......................30

Fig. 4 - Roma na época da morte de Constantino, 337 d.C. ................................................... 32

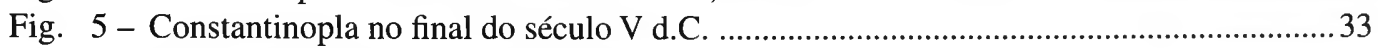

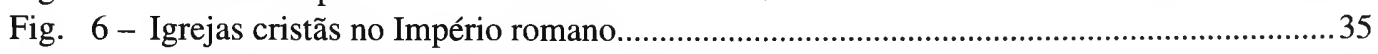

Fig. 7 - Conquistas de Constantino no território romano ............................................................39

Fig. 8 - Planta do Fórum de Pompéia ................................................................................. 161

Fig. 9 - Planta da basílica de Pompéia, construída antes de 78 a.C. ........................................... 162

Fig. 10 - Fachada lateral do Athenaion, atualmente a Catedral de Siracusa...............................162

Fig. 11 - Catedral de Siracusa - vista do interior ....................................................................... 163

Fig. 12 - Templo da Concórdia: ajustes para basilica cristã, segundo a reconstituição de Trizzino ....... 163

Fig. 13 - Vista externa do Templo da Concórdia, em Agrigento ...................................................164

Fig. 14 - Vista da cela do Templo da Concórdia, em Agrigento..................................................... 165

Fig. 15 - Igreja da Natividade, Belém, no tempo de Justiniano................................................... 167

Fig. 16 - Detalhe do capitel - templo de Zeus, Atenas............................................................. 171

Fig. 17 - Detalhe das colunas - Igreja da Natividade, Belém.................................................172

Fig. 18 - Vista do interior - Igreja da Natividade, Belém.......................................................... 173

Fig. 19 - Vista do Pártenon, Atenas ...................................................................................... 174 



\section{PREFÁCIO}

uem visita hoje as muitas cidades
dos paises mediterrânicos pergunta-se como tantos edifícios construídos há mais de dois mil anos pela civilização clássica permanecem ainda hoje em funcionamento. Pontes romanas, templos gregos e outras construções menores tiveram, com efeito, seus espaços ou partes deles re-aproveitados para outras funções no transcorrer dos séculos. Esta pesquisa de mestrado realizada por Regina Helena Rezende tratou justamente de descobrir como e porque antigas construções romanas da Palestina transformaram-se nas primeiras Igrejas cristãs.

Neste estudo, a autora fez um levantamento minucioso e bastante sistemático de 101 igrejas que abrigaram cultos cristãos nos séculos iniciais do cristianismo no Oriente Médio. O levantamento realizado focalizou, sobretudo, o formato das plantas destas Igrejas e sua orientação, elementos melhor perceptíveis no registro arqueológico.

A organização desta documentação permitiu a identificação de muitos elementos clássicos que foram retomados pelo cristianismo nascente, que os ordenou de uma maneira particular de sorte a atender às necessidades da nova religião.

Partindo do princípio de que a arquitetura é uma forma de comunicação não verbal, a autora de- monstra como as plantas-baixas antigas de basílicas romanas que haviam abrigado atividades ligadas ao poder político foram as estruturas escolhidas para abrigar os cultos cristãos que justamente no período estudado associavam-se diretamente ao Estado. Na enormidade do Império Romano do Oriente, o cristianismo foi usado como uma maneira de integração social e de consolidação do poder do Imperador. Com clareza indiscutível, Regina Helena Rezende expõe o problema que pretende investigar, define sua metodologia e lida com sua documentação. O caminho que percorre a conduz ao traçado de suas conclusões com brilhantismo.

Este é um trabalho que demonstra mais uma vez como a Arqueologia, a partir da disposição de algumas pedras no terreno é capaz de desvendar elementos que fundam o funcionamento das sociedades antigas.

Assim, é com grande satisfação que o Programa de Pós-graduação em Arqueologia do MAE/ USP traz a público esta pesquisa.

Maria Beatriz Borba Florenzano 



\section{INTRODUÇÃO}

$F_{\text {estudo das primeiras igrejas, que }}^{\text {ste trabalho tem como objetivo o }}$ são edifícios construídos com a finalidade específica de culto cristão. A partir da compreensão do contexto histórico de construção e uso desses edifícios, buscamos nos aprofundar em dois aspectos. O primeiro deles são as a situações de permanência e de mudança de elementos da arquitetura clássica que podem ser identificadas no estudo dos componentes arquitetônicos das igrejas cristãs, e o segundo é identificar quais os fatores que motivaram a construção dessas igrejas naquele momento e quais as consequiências dessa nova forma para a vida dos indivíduos que fizeram uso dela e para os espaços onde essas igrejas foram inseridas.

Procuramos não nos restringir apenas ao dado material, parte importante no estudo do estabelecimento de uma nova forma arquitetônica, mas buscamos ir além, evidenciando toda uma situação social, política, econômica e cultural de mudança, da qual essa forma também faz parte. Adotando essa postura interpretativa evitamos, por outro lado, entender essas primeiras igrejas cristãs como produto de uma mudança restrita apenas à esfera religiosa, melhor dizendo, como resultado do estabelecimento do cristianismo como religião oficial do Império Romano, por acreditarmos que essa é uma postura muito limitada e restringe o conhecimento que pode ser produzido a partir do dado material a um mero acessório, cuja única função é validar o que o documento escrito nos revela. Por esse motivo, evitamos adotar esse tipo de interpretação e buscamos lidar com todas as nossas fontes, que são os documentos materiais e escritos, dando a elas o seu devido valor, sem que nenhuma delas seja usada como acessório da outra.

Consideramos relevante reproduzir aqui as observações de Levy (1995: 2) a respeito da contribuição dos Annales, escola de história econômica e social desenvolvida por historiadores franceses, tais como Bloch, Braudel e
Febvre, para o campo da arqueologia, presentes na introdução da obra editada por ele - The archaeology of society in the holy land, uma vez que as reflexões apresentadas pelo autor também perpassam questões que serão trabalhadas nessa dissertação. As idéias desenvolvidas pelos Annales, na medida em que enfatizam a questão da generalização e propõem indagações que vão além do exame de um fenômeno singular, são bastante relevantes para as pesquisas arqueológicas realizadas na região da Terra Santa, que apresenta uma variedade de situações em um espaço de milhões de anos. Entendemos por Terra Santa a região da costa leste do Mar Mediterrâneo que abrange os dois lados do Rio Jordão, tendo como limites o Sinai e Eilat, ao sul, e a nascente do Rio Jordão, ao norte.

A escola dos Annales atingiu o seu ponto máximo com a publicação, em 1949, do livro de Fernand Braudel intitulado La Mediterranée et le monde méditerranéen a l'époque de Philippe II. "A recente 'descoberta' da escola dos Annales por arqueólogos de todo o mundo aponta para sua utilidade como quadro teórico apropriado para a pesquisa arqueológica" (Levy 1995:2). Ainda que nos últimos dez anos a aplicação dos conceitos desenvolvidos pela escola dos Annales à arqueologia tenha sido criticada, vemos ainda vários pontos em que a reflexão histórica ali desenvolvida pode ter grande utilidade para a nossa disciplina. Em primeiro lugar, essa escola defende o estudo de aspectos únicos e particulares da história, mas com a intenção de alcançar um entendimento amplo da história humana. Outro aspecto a ser mencionado é que a escola dos Annales procurou incorporar a contribuição dos dados e conceitos provenientes de várias áreas de conhecimento, tais como economia, lingüística, sociologia, antropologia, psicologia e ciências naturais, ao estudo de história. "Esse tipo de apropriação intelectual é notadamente similar à forma de trabalho do arqueólogo, que utiliza 
um amplo espectro de disciplinas para analisar e interpretar seus dados" (Levy 1995:2).

Um dos paradigmas da escola dos $A n$ nales, presente na obra de Braudel sobre o Mediterrâneo e apresentado por Levy (1995:4), diz respeito ao tempo histórico, enquadrado em três grandes grupos que operam contemporaneamente, porém em diferentes níveis através do tempo. São eles:

1. Événements: são eventos, processos de curta duração, tais como narrativas político-históricas e atos de indivíduos;

2. Conjunturas: são processos com períodos médios de duração, que incluem os processos de mudança na história social e econômica; ciclos econômicos, agrários e demográficos; a história processual de eras, regiões e sociedades; e as visões de mundo e ideologias (mentalidades);

3. La longue durée: são processos de longa duração, que cobrem a geo-história e o quadro ambiental que facilitam ao mesmo tempo em que restringem a evolução social; a história das civilizações e sociedades; tecnologia; e visões de mundo (mentalidades).

Como Levy expõe (1995:4), inspirado pelas análises de Bintliff, os événements (eventos) fazem parte do domínio tradicional dos historiadores, uma vez que seus estudos estão mais focados nas atividades humanas e nas personalidades individuais. Por sua vez, o dado arqueológico, devido à sua natureza, onde o indivíduo normalmente escapa do seu entendimento, não funciona na maior parte das ocasiões em que se procura operacionalizá-lo como uma ferramenta explicativa dos événements. A conjuntura e a longue durée, por se tratarem de processos que abrangem um intervalo maior de tempo, mostram-se mais adequados à pesquisa arqueológica, uma vez que os dados obtidos por essa ciência são capazes de evidenciar os processos que a conjuntura e a longa duração também buscam interpretar. É nesse sentido que a arqueologia se destaca das outras disciplinas e se identifica com esses dois processos: pela sua sensibilidade à mudança cultural em longos intervalos de tempo, trabalhando o artefato enquanto dado que revela a vida cotidiana dos indivíduos comuns.
Ressaltamos também a importância da obra The corrupting sea, de Horden e Purcell (2000), para este trabalho. Esses autores também referenciam a escola dos Annales e principalmente o trabalho de Braudel sobre o Mediterrâneo em suas reflexões. Nessa obra eles desenvolveram um extenso e detalhado estudo, onde exploram o recorte histórico e a região (o Mediterrâneo) que configura nosso objeto de estudo. Esses autores propõem entender o $\mathrm{Me}$ diterrâneo, desde as culturas mais remotas até a modernidade, a partir de uma visão que eles definem como ecologia histórica, alinhada com uma tendência observada em trabalhos recentes nas áreas de história e arqueologia, onde o estudo de um assunto pontual, seja ele um aspecto da economia, uma cidade ou um edifício, é realizado de maneira ampla, não procurando mais identificar suas características particulares, mas suas semelhanças com outras situações similares, e não mais se restringindo ao objeto de estudo em si, mas procurando observar em detalhe o contexto onde ele se insere (Horden e Purcell 2000:passim). A postura adotada por esses autores, de ir além do particular para entender uma situação a partir de uma perspectiva ampla, está alinhada com a proposta de Levy (1995:4), que defende o uso dos paradigmas de média e longa duração desenvolvidos pela escola dos Annales para a construção do conhecimento em arqueologia. Essa é uma postura que partilhamos e é nesse sentido que procuramos desenvolver o estudo que aqui se apresenta.

Dois dos aspectos que Levy (1995:5) destaca como contribuições positivas dos modelos dos Annales para a arqueologia da região da Palestina são relevantes para nosso trabalho. O primeiro deles é o modelo conciso, desenvolvido por Braudel, de como a mudança acontece em diferentes contextos temporais, utilizado na maioria das vezes em investigações que combinam o dado arqueológico com o histórico. Esse é o nosso caso, uma vez que trabalhamos com fontes históricas e dados de escavações a fim de identificar a permanência das formas clássicas nas primeiras igrejas cristãs, que, como veremos adiante, pertencem a outro contexto temporal. Outro aspecto presente nessa dissertação diz respeito à natureza do dado arqueológico, que usualmente obstrui a identificação do indi- 
víduo no seu registro. Consequentemente, esse dado trata das estruturas de mudança de médios e longos períodos. Essa é uma questão de extrema importância e que se procurou tratar com o máximo de cuidado no nosso caso, pois, apesar da importância da figura de Constantino para o momento de transformação que abordamos e que não se restringe apenas ao aspecto da religião - com o despontar do cristianismo e da nova forma de edifício de culto - mas envolve também as esferas política, social, econômica e cultural, não podemos considerar essa mudança limitada somente à sua figura. A partir das fontes históricas e dos dados arqueológicos percebemos que a situação de transformação não durou apenas os anos que Constantino governou, mas permaneceu por séculos, ocorrendo antes e depois de sua existência. Por isso, restringir esse estudo apenas ao período em que as realizações de Constantino aconteceram não dá conta do entendimento de toda essa situação. Em função de tudo o que foi exposto, optamos por um recorte temporal amplo, que abarca o intervalo de alguns séculos.

Delimitamos nosso recorte temporal também em função do recorte geográfico. A Palestina foi a região onde Jesus Cristo, a figura a partir da qual se configurou a religião cristã a partir do século I d.C., nasceu, viveu e morreu. Desde os primeiros séculos da nossa era essa região foi adotada como local de peregrinação e centro de culto dos cristãos. A importância desse lugar para o cristianismo torna-se evidente pela quantidade de igrejas que foram encontradas no local e por todos esses motivos, a Palestina foi a região escolhida para o desenvolvimento da pesquisa. Por outro lado, procuramos não olhar para a região escolhida como um território isolado, mas como parte do Império Romano na Antiguidade Tardia, apresentando um panorama da organização geral desse império, e sempre que necessário pontuando as situações mais específicas do Oriente Próximo e em particular da região da Palestina.

A partir do tempo de Augusto, que se iniciou no último quarto do século I a.C., o Império cresceu, e o cristianismo floresceu com ele. Estamos de acordo com Millar, ao afirmar que "se a história social e cultural do Oriente Próximo entre Augusto e Constantino pode ser entendida em sua totalidade, é somente dentro do quadro criado pelo poder Imperial" (Millar 1993:22-23), referindo-se à inegável influência que o Império Romano exerceu sobre as regiões dominadas por ele.

O cristianismo enquanto religião havia se estruturado e se difundido por todo o Império Romano desde o século I de nossa era, mas somente a partir da primeira metade do século IV d.C., ao se tornar a religião oficial desse Império Romano, ele adquire amplitude. Nessa época, sua forma de organização interna enquanto culto religioso já estava bem estabelecida e aparentemente se adequou aos propósitos do imperador Constantino, que acabou por adotá-lo como religião imperial e dessa maneira tornou o seu culto oficial. Na época do seu surgimento Roma estava em plena expansão do seu império, conquistando territórios e dominando povos existentes em volta do Mar Mediterrâneo na Europa, África e Ásia. Dessa maneira, procurar entender como o cristianismo se organizou desde seu surgimento como crença até a primeira fase de grande expansão da religião, quando as primeiras igrejas foram construídas, passa pela compreensão de como o Império Romano se configurou e organizou sua dominação ao longo desses séculos. Nesse quadro não se pode ignorar o papel do imperador Constantino, figura-chave para que o cristianismo saísse das sombras e se tornasse uma das religiões mais importantes no mundo até os dias de hoje. Mas a sua atuação deve ser entendida dentro da situação que o Império Romano viveu até chegar a ele e quais os desdobramentos que lhe sucederam. Nesse sentido, procuramos nos alinhar à proposta de Levy, inspirado pela escola dos Annales, para o estudo da região da Palestina, entendendo a situação de estabelecimento da nova religião como um processo de média ou longa duração e não apenas a partir de um evento isolado.

Assim como em todo o Império Romano, a construção de igrejas na Palestina teve seu início na primeira metade do século IV d.C., durante o governo de Constantino, e segue em um movimento ascendente até a segunda metade do século VI d.C., quando Justiniano I governava a parte oriental do Império. Cerca de um século depois, em 638 d.C., a Palestina foi conquistada 
por árabes muçulmanos e a partir desse momento notamos que, além da construção de igrejas nessa região parar, muitas delas são destruídas. Pela sua relevância, optamos por estudar as igrejas construídas no período que abrange desde o governo de Constantino e se estende até cerca de 50 anos depois de Justiniano I, adotando como recorte temporal um intervalo de quase três séculos, que vai da primeira metade do século IV até o final do século VI d.C. Esse recorte temporal se enquadra em uma época conhecida na história como Período Bizantino. No que diz respeito ao espaço temporal que esse período abrange, no desenvolvimento de nossas pesquisas nos deparamos com duas vertentes que adotam recortes temporais diversos. De um lado temos os historiadores ocidentais, para quem o Período Bizantino é um momento da história que tem início em 330 d.C., quando Constantino funda a cidade de Bizâncio, posteriormente chamada de Constantinopla, e se encerra no ano 1453 d.C., quando essa cidade foi tomada pelos turcos. Outra vertente reúne os historiadores do Oriente, pois eles entendem que o Período Bizantino se inicia em 324 d.C., quando Constantino derrota Licínio, que governava a parte oriental do Império Romano, tornando-se assim o único governante desse império; para esses estudiosos, o período se encerra em 638 d.C., quando os árabes invadem a região da Palestina. Decidimos nomear o espaço de tempo estudado nessa dissertação como Período Bizantino, uma vez que o nosso recorte temporal está dentro do intervalo adotado como Período Bizantino para ambas as vertentes interpretativas.

Para o desenvolvimento desse estudo, gostaríamos de esclarecer alguns pontos. Em primeiro lugar, devemos entender que as formas de expressão da cultura da região do Oriente Próximo, envolvendo arquitetura, escultura, pinturas murais, inscrições em grego, latim e uma variedade de línguas semíticas, incluindo o árabe, existiram dentro da moldura do Império Romano ou de seus reinos dependentes. Não se observa como resultado do contato entre os habitantes da região da Palestina e os costumes romanos um abandono da identidade cultural por esses povos; as influências culturais que se estabelecem nessa região funcionam mais como uma situação de troca e interação entre a cul- tura dos povos dominados e os hábitos romanos. Aspectos da cultura ou das culturas locais dessa região que existiram no Império Romano podem ter sobrevivido e chegado ao nosso conhecimento. Um dos meios de sobrevivência da cultura são os vestígios materiais estudados pela arqueologia. Entendemos as igrejas examinadas nesse trabalho como vestígios materiais de uma cultura que se configura na região da Palestina a partir de seu contato com o modo de vida romano e, por isso, consideramos que a arqueologia nos fornece instrumentos apropriados para o desenvolvimento desse estudo.

No que diz respeito à região escolhida como nosso recorte geográfico, é válido observar que ela pode ser designada por uma variedade de nomes próprios. Como Stern (1993:XIII) apresenta na explicação da enciclopédia por ele editada, alguns desses nomes são antigos, como Canaã, Judéia, Ammon, Moab, Philista, Transjordânia, Terra Santa e Palestina, e outros são modernos, como Israel, Jordânia e Síria. Tendo em vista todas essas possibilidades de denominação para a região, optamos por usar o nome que fosse mais adequado ao local a partir do momento histórico que nos propusemos a estudar. Assim, adotamos a denominação de Palestina porque esse foi o nome utilizado no século IV d.C. pelos romanos para essa região (Millar 2001:192-193).

$\mathrm{Na}$ bibliografia consultada encontramos o uso de dois termos para denominar as primeiras igrejas cristãs em um momento inicial do cristianismo. São eles: protocristão e paleocristão. Como observamos o uso dessas duas denominações de forma indistinta, optamos por considerá-las sinônimas e passamos a utilizar os dois modos de escrita.

Julgamos conveniente informar que todas as traduções de trechos de textos em língua estrangeira que aparecem nessa dissertação foram realizadas por nós, visando ao acesso daqueles que não têm o conhecimento dessas línguas.

Para finalizar, comentamos a seguir a estrutura adotada nesse trabalho, que foi dividido em quatro capítulos principais.

No desenvolvimento do estudo, vimos a necessidade de conhecer um arcabouço teórico e metodológico que nos fornecesse os ins- 
trumentos necessários para entender as questões levantadas, proporcionando-nos o conhecimento adequado para explorar ao máximo as possibilidades interpretativas que o nosso objeto de estudo poderia oferecer. Logo de início notamos que o estudo de teorias no campo da arqueologia não daria conta de explorar nossas igrejas da maneira que desejávamos. Assim, buscamos nos campos da arquitetura e da história da arte um embasamento que nos habilitou a analisar nosso objeto de estudo sob outros prismas. A partir da leitura de várias vertentes interpretativas empreendemos uma reflexão crítica a respeito do uso de uma forma arquitetônica como expressão do modo de vida de uma sociedade, aplicando o conhecimento constituído para compreender de que maneira as igrejas cristãs são a manifestação de uma nova visão de mundo. Esse é o conteúdo do capítulo 1, que foi dividido em subcapítulos a partir da área do conhecimento ao qual se relacionam. O final desse capítulo é dedicado a um balanço crítico e à apresentação de possíveis interações dessas vertentes aplicadas ao nosso objeto de estudo.

Tendo nos conscientizado a respeito de todas essas questões, no capítulo 2 tratamos do momento histórico de construção das igrejas e do estabelecimento do cristianismo no Império Romano. Nos aprofundamos no estudo da história desse período, tanto a partir das fontes históricas como a partir de produções recentes a respeito do Império Romano Tardio, da organização política, econômica e social, assim como da configuração urbana das colônias nesse período, da arte e arquitetura no Período Bizantino e também a respeito da figura de Constantino.

Pudemos observar a partir desse quadro a importância do Império Romano enquanto estrutura organizada para a difusão da religião cristã e do Imperador Constantino no processo de expansão do cristianismo pelo império e no estabelecimento das igrejas como edifícios de culto cristão. Também procuramos explorar a organização das cidades durante o Império Romano Tardio, focando principalmente nas colônias da parte oriental, mais especificamente na região da Palestina, observando de que maneira a sua configuração espacial recebeu a nova forma na qual se configurava as igrejas. $O$ estudo do cristianismo enquanto religião, sua organiza- ção e seu desenvolvimento até a época de Constantino também foram nosso objeto de análise, assim como a arquitetura e a arte produzidas no Período Bizantino.

Paralelamente ao estudo das vertentes metodológicas e da história do período que pretendemos abordar, elaboramos um corpus documental das igrejas, que resultou no catálogo apresentado no capítulo 3 dessa dissertação. Grande parte das informações utilizadas para a elaboração do catálogo foi obtida a partir de relatórios de escavações. Não tivemos acesso direto a esses relatórios, mas os dados que eles apresentam foram obtidos a partir de duas obras: a The new encyclopedia of archaeological excavations in the holy land, editada por Stern (1993), e a Ancient churches revealed, editada por Tsafrir (1993). As informações obtidas a partir dessas duas fontes revelaram que, em grande parte das igrejas cristãs da região da Palestina que se enquadravam no recorte temporal estipulado, pouca coisa restou. Como muitas delas foram destruídas no intervalo de tempo de sua construção até os dias de hoje, o que geralmente os arqueólogos conseguiram recuperar foram as fundações das paredes e partes dos pisos, resultando em desenhos em planta e esquemas decorativos dos pisos em mosaico. Optamos por não abordar a questão dos pisos, sobretudo dos pavimentos em mosaicos das igrejas, porque eles não se encaixavam no escopo inicial de nosso trabalho e o seu estudo, dada a quantidade e a riqueza do material existente, poderia ser tema para outro trabalho. Assim, para a análise da arquitetura das igrejas protocristãs, que foi o objetivo proposto para esse estudo, trabalhamos basicamente com o seu desenho em planta, que foi o que os estudos arqueológicos foram capazes de produzir a partir das informações obtidas pelo trabalho de campo. Com relação aos elementos decorativos das igrejas, além dos mosaicos há pouca informação a esse respeito. Obtivemos apenas alguns dados relativo às colunas e aos capitéis dessas igrejas, mas mesmo assim optamos por mostrá-los. Como introdução ao catálogo, apresentamos no início desse capítulo os critérios adotados para a sua seleção e organização, um mapa de localização das igrejas e, ao final, algumas tabelas comparativas que sintetizam os dados obtidos. 
No capítulo 4 apresentamos uma análise dos dados colhidos a partir do catálogo e das tabelas. $\mathrm{O}$ que mais nos chamou a atenção foi a ocorrência da forma de basílica nas igrejas paleocristãs. A partir desse dado, procuramos explorar essa forma de diversas maneiras, abrangendo tanto os aspectos formais - observando os tipos anteriores que marcam a sua permanência nesse edifício, as inovações que ele apresenta, sua ocorrência ao longo do período estudado e sua orientação - quanto os aspectos sociais, políticos, econômicos e culturais que estão envolvidos na sua preservação.

Para entender o contexto de manutenção da forma da basílica nas igrejas cristãs nos apro- fundamos no quadro histórico do Império Romano no período anterior à sua criação e na figura de Constantino, pelo papel marcante que esse imperador teve no desenvolvimento da religião cristã. Compreender a arquitetura com a sua própria linguagem, como forma de comunicação não-verbal, nos permitiu ver as igrejas protocristãs de maneira mais rica. Procuramos entendê-las não como mera ilustração, mas como a manifestação formal dos meios de dominação e, também, como parte integrante de todo o processo de transformação que tanto a região da Palestina quanto o Império Romano como um todo estava sofrendo.

Isso nos possibilitou ver os acontecimentos sob uma nova ótica e, assim, compreendê-los em maior profundidade. 


\section{1 - Arquitetura e sociedade - algumas vertentes interpretativas}

Como foi exposto na introdução, a
proposta dessa dissertação é entender, a partir das igrejas paleocristãs, um tipo de construção que tem o seu surgimento bem documentado, como um novo modelo arquitetônico é criado e pode se transformar ao longo do tempo, observando o que ele preserva das formas antigas e quais inovações lhes são acrescentadas, explorando quais as causas e os limites dessa mudança. Para compreender como se dá essa transformação, buscamos um embasamento teórico pertinente ao tema estudado, nos informando acerca de teorias de interpretação nas áreas de arquitetura, arqueologia e também história da arte, de modo a construir um arcabouço teóricometodológico que nos auxiliasse na interpretação do nosso objeto de estudo, que são as igrejas construídas na região da Palestina entre os séculos IV a VI d.c.

Entendemos esses edifícios como cultura material, que expressa religião e ideologia $\mathrm{e}$, em suas formas, procuramos identificar como eles reforçam, modificam ou destroem as organizações sociais estabelecidas.

A seguir, faremos breve exposição das teorias estudadas, apontando sempre que possível qual o seu interesse para esse trabalho.

\section{Arqueologia}

Essa investigação pode ser inserida em um campo de estudos arqueológicos chamado "Arqueologia da Arquitetura", que reúne trabalhos onde a arquitetura é vista e analisada a partir de uma perspectiva arqueológica. Essa área do conhecimento procura ver as construções como elementos ativos, produtos culturais que interagem de forma dinâmica com o homem.
Ela reúne estudos que apresentam posições teóricas diferentes, até mesmo opostas; uma delas podemos chamar de "prática" - engloba aqueles que vêem a arquitetura de maneira funcional, como o resultado lógico de necessidades naturais humanas, como abrigo; e a outra, a "teórica" - reúne os que estudam o seu caráter simbólico, ressaltando a presença dos sistemas ideológicos que também influem na forma de se conceber um edifício. Estudiosos da área, como Pearson e Richards (1997), McGuire e Schiffer (1983), vêem a produção de arquitetura sob essas duas óticas, a "prática" e a "teórica" em conjunto. Além disso, mostram que a arquitetura tem e expressa certos "princípios" de ordem e classificação que são básicos para o funcionamento da sociedade (Pearson 1997:37).

Contrariamente à paisagem dada pela natureza, a paisagem artificial produzida pela arquitetura é pensada, desenhada e construída pelos homens. Essa condição faz da arquitetura um produto carregado de componentes ideológicos - de sentidos e intenções (Zarankin 1999:239).

O espaço é prática de nossas ações cotidianas; é também um símbolo, e nós deveríamos conceber a arquitetura como tecnologia simbólica. Os sentidos que são dados aos lugares e à ordem espacial não são fixados ou invariavelmente dados, mas devem ser invocados no contexto da prática e uso recorrente. Os sentidos aderem ao espaço somente por meio da atividade humana. No entanto, a capacidade de reinterpretar e mudar os sentidos e as ideologias é restrita pela ordem espacial existente. Em outras palavras, "nós fazemos história não como desejamos, mas sob circunstâncias que não escolhemos. O relacionamento entre forma espacial e intervenção humana é mediado pelo sentido" (Pearson 1997: 5).

Existem vários princípios organizadores envolvidos na produção social da arquitetura, incluindo contaminações por gênero e sexo, 
modelos de parentesco, ligações com o cosmos e a terra, segregação de indivíduos por idade e status social. Outros princípios organizadores derivam do nosso ambiente. Em função deles, criam-se diferentes configurações espaciais, tais como: oposições estruturais, estabelecimento de um axis mundi e de uma imago mundi, estruturação concêntrica do espaço, abrangendo centro e periferia ou um conjunto de zonas concêntricas, organização diametral, que determina um ou mais eixos, como aquela que segue os quatro pontos cardeais, reversos do espaço fechado, e homólogos do corpo e do cosmos. Esses princípios também são elementos comuns de um sistema básico de regras e convenções. Com a imposição e articulação desses vários princípios básicos, os indivíduos criaram a ordem (cosmos) sobre a desordem primitiva (chaos) (Pearson 1997:10-11; 28-29).

Em sua obra, Pearson procura nos mostrar como a arquitetura incorpora e expressa certos princípios de ordem e classificação. Como um espaço cultural construído, ela é um contexto definido onde as pessoas realizam atividades particulares em tempos próprios. Os indivíduos se movimentam através de seus confinamentos e fazem coisas em locais apropriados. Portanto, o sentido do espaço é realizado por meio das práticas sociais. Tal contingência permite a redefinição do espaço sem necessariamente alterar suas propriedades físicas (Pearson 1997:40). Para o arqueólogo, essas mudanças potenciais no sentido do espaço dentro de qualquer forma arquitetônica são claramente problemáticas, uma vez que faz com que o mesmo registro de cultura material tenha diversos significados. Mas isso não representa um obstáculo intransponível para o estudo de povos do passado, uma vez que uma análise cuidadosa da cultura material muitas vezes pode evidenciar essas sutis mudanças de significado.

$\mathrm{Na}$ arqueologia, onde a pesquisa se baseia na "leitura" de objetos materiais, a importância da "análise contextual" tem sido realçada. Dessa forma, o significado do objeto arqueológico só pode ser deduzido se o contexto do local onde ele foi encontrado for conhecido. Existem dois caminhos para se trabalhar: se os artefatos e os comportamentos são conhecidos, eles auxiliam na definição da natureza do espaço; ou se o ambiente é conhecido, ele pode auxiliar na definição da natureza dos objetos que nele são encontrados. A consequiência mais importante da relação entre padrões de comportamento e aqueles artefatos chamados espaços construídos é que os últimos guiam os primeiros; eles lembram aos indivíduos como agir, como co-agir ou o que fazer. Eles guiam e restringem o comportamento, sem serem determinantes (Rapoport 1982:83).

Nesse sentido não podemos ignorar a contribuição de Pierre Bourdieu que, como Giddens, formalizou o papel da ação, ou práxis, na produção e reprodução do sentido e das estruturas nas ordens socioespaciais. Ao se concentrar na dimensão espacial da ação, Bourdieu relaciona a teoria social não apenas com o espaço, mas também com o tempo. A teoria de Anthony Giddens sobre estruturação, por sua vez, argumenta que o espaço deve ser incorporado à teoria social, não como um ambiente, mas como parte integral do acontecimento do comportamento social. Qualquer padrão de interação ocorre no tempo e no espaço (Lawrence e Low 1990:469-470; 489). Ao inserir a relação com o tempo nas interações entre o indivíduo e a arquitetura, esses autores dão valor à dimensão histórica, considerando-a importante suporte para a interpretação dos fenômenos dessa natureza.

Com isso, a arquitetura torna-se um caminho para o estudo do mundo social por ser um elemento constitutivo da paisagem humana. Por meio da análise de uma forma arquitetônica podemos conhecer importantes aspectos relacionados ao modo de vida e visão de mundo das sociedades que a produziram. Da mesma maneira, o processo inverso pode acontecer, isto é, o conhecimento da cultura que produziu a forma arquitetônica a ser estudada também pode nos fornecer subsídios para interpretação da mudança ou permanência da forma nas condições propostas para esse trabalho. É nesse sentido que vamos direcionar o estudo sobre as igrejas protocristãs.

Existem teorias sobre a produção social da forma construída que merecem ser levadas em consideração, porque se concentram nas forças sociais, políticas e econômicas que produzem o ambiente construído e, reciprocamente, no impacto do ambiente construído na ação social. Essas teorias dão ênfase ao fenômeno ur- 
bano e às forças institucionais, e nos contextos históricos e socioculturais de mudança dentro dos quais a forma construída existe. Anthony D. King, grande defensor da história social das formas construídas, entende espaço construído como um produto essencialmente social e cultural. As necessidades dessas esferas resultam em edificações, construídas para acomodar uma variedade de funções - econômica, social, política, religiosa e cultural. Seu tamanho, aparência, posição e forma não são regidos apenas por fatores físicos (clima, materiais ou topografia), mas pelas idéias da sociedade, suas formas de organização social e econômica, a distribuição de recursos e governo, atividades, crenças e valores que prevalecem em cada período do tempo. A sociedade produz edifícios que mantêm e/ ou reforçam formas sociais (Lawrence e Low 1990:482-483).

A arquitetura, pelos seus componentes ideológicos, pode ser estudada como uma fonte potencial de informação antropológica. Assim, alguns autores, como, McGuire e Schiffer (1983: 280), afirmam que a vantagem de trabalhar com arquitetura é que ela expressa tanto funções utilitárias como simbólicas. Na teoria do projeto arquitetônico, esses estudiosos tratam as formas construídas como produto de um processo social, formas essas com objetivos simbólicos, como expressar diferenças de status; elas também servem para fins utilitários, mediando as relações humanas com o meio-ambiente e acomodando necessidades psicológicas. Com a sociedade tornando-se mais complexa, cresce a acumulação de riquezas e a desigualdade social, e assim investe-se mais em construção, diminuindo os custos de manutenção. Verificase que, nessas sociedades, a arquitetura torna-se um veículo de representação das diferenças de status (Lawrence e Low 1990:463).

Quanto à organização do espaço, vimos que vários autores destacam a existência de um propósito ideológico além da função prática, mas não atribuem essa intenção a nenhum grupo em especial. Zarankin vai além nesse sentido, porque evidencia a existência de vertentes de pensamento bem definidas na transformação de uma forma construída, mas a atribui invariavelmente a um jogo de dominação. Segundo esse autor, "a organização e a estruturação do espaço em qualquer assentamento humano é o resultado da ação de uma série de valores e objetivos que podemos interpretar como ideologias. Dentro de qualquer sociedade existe uma variedade de ideologias, que em termos gerais podem dividir-se em dominantes e dominadas" (Zarankin e Acuto 1999:247). Para Zarankin, no contexto de uma paisagem que é construída pelo homem por meio de um jogo dialético de dominação e resistência, a arquitetura pode ser vista como um espaço de lutas entre poderes e ideologias contrárias. Esses autores, na medida em que ressaltam a importância do espaço construído não apenas pela sua forma, mas também pelo sentido ideológico que ela traz consigo, chamam a nossa atenção para o tipo de interpretação que pretendemos desenvolver a respeito desse assunto. Tendo essas questões em mente, o estudo das nossas igrejas não pode ficar restrito à sua análise formal, mas deve considerar também os aspectos sociais, políticos, econômicos e culturais que elas representam.

Uma sociedade, qualquer que seja ela, é estruturada por grupos dominantes e dominados. O dominante se utiliza da capacidade de controlar o espaço como ferramenta que o auxilia no exercício do poder. É assim que a arquitetura é vista por Zarankin em seus trabalhos, como uma tecnologia de poder, um instrumento disciplinador do espaço e de construção da paisagem cultural. A sua manipulação por parte de um grupo pode ser considerada como uma estratégia do poder para se perpetuar (Zarankin 1999: 267).

A casa familiar e a escola capitalista são entendidas por Zarankin (1999) como elementos disciplinadores do sistema. Tanto no estudo da transformação das moradias ao longo do tempo, relacionadas com o desenvolvimento do capitalismo na Argentina, quanto no seu estudo sobre a arquitetura escolar capitalista em Buenos Aires, ele observa no desenho desses espaços uma tendência de aumento nos aspectos restritivos, e os interpreta como uma maneira de materialização de critérios e controle.

Zarankin afirma, inspirado em Miller: "a oposição entre as novas formas e as antigas cria uma tensão e uma dinâmica contínuas, que não são totalmente controladas por aqueles que criam a paisagem" (Zarankin 1999:247). Isso 
é o que acontece quando grupos que detêm o poder, determinando a política e/ou a ideologia dominante, são substituídos por outros: a paisagem urbana não é completamente reestruturada, e então se observa que numa cidade convivem variadas construções que foram aparecendo com o tempo.

Pelo trabalho desse estudioso vemos que idéia de se produzir arquitetura como modo de reforçar ou manter certas formas sociais pode ser expandida, e por meio dela se pensar o uso do espaço construído como mecanismo de instauração de poder de um grupo sobre outros, ou como este espaço funciona como um objeto de luta social. Porém, como veremos no final deste capítulo, não estamos de acordo com a opinião de Zarankin quando ele atribui a transformação na forma arquitetônica como materialização do enfrentamento entre grupos dominantes e dominados.

Não se pode ignorar as forças complexas e as formas institucionais em larga escala que penetram em cada ângulo dos estabelecimentos urbanos. Os edifícios constituem investimentos substanciais para qualquer sociedade, e em várias delas seu aproveitamento sobrevive ao construtor original. Por serem capazes de atravessar mais do que uma geração, essas construções tornam-se importantes repositórios de informação cultural. As condições de sua construção original, e cada camada sucessiva de renovação, são partes integrantes das culturas que as criaram. Dessa maneira, como um objeto de estudo, o edifício torna-se um ponto de articulação espacial para a interação de forças múltiplas de economia, sociedade e cultura (Lawrence e Low 1990:492).

Como objeto material carregado de conotações ideológicas e simbólicas a arquitetura é capaz de estabelecer relações com o contexto social no qual ela se insere. Se a entendermos como um tipo particular de linguagem, com uma dinâmica própria, veremos que ela constitui uma forma de comunicação não-verbal, e que, portanto, pode ser "lida" É importante ressaltar que a comunicação não-verbal tem sua própria coerência formal, difícil de ser reduzida a "estruturas" de sentido verbal (Fletcher 1989:36). O desafio que se coloca à nossa frente é "traduzir" essa linguagem não-verbal - o edifício
- para uma linguagem verbal coerente, em um texto possível de ser decodificado. Para que essa leitura possa ser realizada de maneira adequada, devem-se encontrar os laços entre os edifícios e a linguagem.

\section{Arquitetura}

Amos Rapoport (1982) foi um dos pioneiros a estudar a construção da paisagem humana. Sua obra denota cuidadosa pesquisa sobre formas construídas e revela uma congruência entre duas grandes vertentes teóricas: de um lado, a interpretação descritiva e atenta ao desenvolvimento da forma, produzida por profissionais do projeto, e de outro a análise direcionada aos aspectos cognitivos e culturais relativos à interação do indivíduo com o espaço. Sobre esse assunto os pesquisadores da área das ciências sociais e humanas se dedicam mais. Ele realizou vários estudos sobre um tema que denominou de: "human built environment" o ambiente humano construído, onde procura explicitar a relação entre o meio ambiente e a construção do espaço humano, aprofundando-se na maneira como eles interagem. Para esse autor, existe uma relação direta entre cultura e meio-ambiente, e a arquitetura reflete esse contato. Como o espaço é pensado antes de ser construído, ele traz diversas referências, entre os quais podem se incluir componentes ideológicas. Toda forma arquitetônica, por sua construção e organização espacial, traz informação relevante sobre a sociedade a que pertence, recebe e fornece referências aos indivíduos que dela se utilizam.

Por meio de suas análises, Rapoport procura compreender como a cultura gera as formas construídas e de que forma o sentido é transmitido em forma de comunicação não-verbal em razão do ambiente construído. Dessa maneira, esse ambiente proporciona ao indivíduo que dele desfruta certa leitura, determinando o seu comportamento nele. Seu desenho é visto como parte de um processo de informações codificadas e que cabe a seus usuários decodificá- 
las. Quando o código é apreendido, o ambiente e seu sentido têm importante papel para nos auxiliar a julgar pessoas e situações pelo significado das pistas fornecidas e interpretadas para uma cultura ou subcultura particular (Rapoport 1982:59).

Em um de seus livros, House Form and Culture, Rapoport adota uma visão multicausal, holística e cultural para interpretar o resultado da ação humana sobre o ambiente, rejeitando uma explicação determinista e baseada num único fator. Para ele é o modo de vida do grupo, definido como uma integração de todos os aspectos culturais, materiais, espirituais e sociais, que melhor explica as variações na forma do espaço construído (Rapoport 1969:46).

O meio ambiente proporciona muitas possibilidades, dentre as quais as escolhas são feitas pelos costumes e as formas tradicionais da cultura. Mesmo numa situação em que as possibilidades físicas que se apresentam são variadas, as diretrizes podem ser limitadas pela matriz cultural. Essa limitação pode representar o aspecto mais característico das habitações e do estabelecimento formal de uma cultura ( $\mathrm{Ra}$ poport 1969:47). Assim, ao se estudar um espaço construído, é muito importante conhecer as características da cultura que o produziu, como seus ideais implícitos, a maneira socialmente correta de agir e os comportamentos inaceitáveis, pois essas características afetam desde a configuração da casa até o espaço construído como um todo.

Segundo Rapoport (1982:58), é o espaço físico que dá as pistas que determinam o comportamento do indivíduo numa situação social. As pessoas agem tipicamente de acordo com a leitura que fazem das pistas que o ambiente fornece. $\mathrm{O}$ ambiente comunica de alguma maneira um comportamento esperado, mas somente se o que comunica possa ser compreendido pelo seu interlocutor. Como conseqüência, temos que a "linguagem" usada nessas pistas deve ser compreendida, isto é, o código deve ser lido. Se o planejamento de um espaço é visto como um processo de codificação de informações, seus usuários podem ser vistos como decodificadores delas. Se o código não é compartil hado ou entendido, o ambiente não estabelece a comunicação. Essa situação corresponde à experiência de estar num contexto que não é familiar ao indivíduo, em que pode ocorrer, por exemplo, um choque cultural. Contudo, quando o código espacial é conhecido, o comportamento pode facilmente se fazer apropriado ao ambiente e à situação social ao qual ele corresponde.

Os membros de uma cultura conhecem os ambientes e situações aos quais se relacionam. Culturas diferentes têm espaços diferentes, e o comportamento apropriado para cenários aparentemente semelhantes pode variar para diferentes grupos culturais. Porém, um ambiente apropriado restringe as possibilidades de escolha. Muitos aspectos da cultura consistem em comportamentos habituais, rotineiros, que são quase automáticos. Nas culturas tradicionais, uma vez que o leque de possibilidades é restrito, as respostas tendem a ser mais automáticas, consistentes e uniformes. Se as regras se realizam em espaço bastante conhecido, no qual as pistas que o identificam são bem consistentes e não ambíguas, ele provoca significados apropriados, situações bem definidas e, portanto, um comportamento adequado (Rapoport 1982:61-62).

Usualmente o aprendizado dos códigos de comportamento ocorre muito cedo na vida de um indivíduo, isto é, durante o processo de enculturação. Para imigrantes e em períodos em que há uma rápida mudança ou contato cultural, esse processo pode ocorrer mais tarde, e será conhecido como aculturação. O papel que o espaço tem nesse processo é claro. Em termos mais gerais, ele pode ser visto como uma forma de aprendizado. Uma vez que se aprende as regras de comportamento, o ambiente torna-se um esquema que remete à memória, condicionando o comportamento adequado (Rapoport 1982: 65-67).

Consideramos importante destacar o trabalho de Amos Rapoport por vários motivos. Em primeiro lugar, porque ele procura olhar o espaço de duas maneiras: com a visão do profissional de projeto, ao colher diversos exemplos e registrar detalhes de sua configuração, mas também com o olhar do pesquisador humanista, atento às formas de comportamento e visão de mundo dos grupos estudados e sua relação com o espaço. Um segundo aspecto de sua obra, que julgamos relevante, é considerar que o ambiente 
construído constitui uma forma de comunicação não-verbal, que encerra um conjunto de códigos de comportamento. $\mathrm{O}$ indivíduo que o conhece consegue interpretar, "ler as pistas" que o ambiente lhe dá, comportando-se de acordo com o que a linguagem lhe solicita.

Complementando o que já foi mostrado nesse ítem, em que entendemos a arquitetura como uma linguagem particular, existe outra área de pesquisa relevante para o nosso trabalho, que é a semiótica da arquitetura, e cuja análise consiste em compreender o ambiente construído como uma linguagem. Esta é entendida como um sistema de signos ou códigos, que busca tornar implícitos significados que estão explícitos. As análises semióticas podem parecer superficiais em comparação com outros tipos de análise, porque fazem uso sistemático das estruturas simbólicas ou cognitivas culturalmente elaboradas, a fim de interpretar o código arquitetônico (Lawrence e Low 1990:470). Umberto Eco, estudioso conhecido em semiótica e que trabalhou na sua relação com o fenômeno arquitetônico, chama a atenção para o fato de os elementos de arquitetura terem também funções não-lingüísticas, fazendo com que eles não possuam análogos aos sinais lingüísticos, tornando-se mais difíceis e complexos de se interpretar.

A relação entre o indivíduo ou um grupo e o espaço construído pode ocorrer de duas maneiras: o grupo cria o espaço em função de sua cultura e da forma de comportamento que desejar ou o espaço, que determina, pela sua configuração, o comportamento adequado para ele. Não se deve perder a perspectiva diacrônica dessa relação, que nos mostra como a transformação do espaço construído e da sociedade que o produziu andam a par e passo no tempo, denotando a forte ligação entre esses dois aspectos. Segundo Pearson (1997:5), esse determinismo arquitetônico propõe dois relacionamentos causais: tanto o comportamento determina a forma de um ambiente ("a forma segue a função"), quanto tal comportamento é resultado do ambiente ("a função segue a forma").

Como outro estudioso do espaço coloca, devemos entender que os edifícios são construídos para obter respostas específicas, e as mudanças identificadas na ordenação do espaço arquitetônico acompanham as transformações sociais (Perring 1991:273).
No seu estudo sobre o uso do espaço no reino Kandy, Duncan (1990:4-5) estuda o papel da paisagem na constituição da prática social e política, destacando como a vida social, e particularmente as relações de poder são constituídas, reproduzidas e contestadas no espaço construído. Também o artigo de Monks (1992) sobre o simbolismo arquitetônico e comunicação não-verbal em Forte Garry segue essa linha de estudo desenvolvida por Duncan, como forma de entender que as mudanças na arquitetura desse Forte estão intimamente ligadas a mudanças econômicas e sociais no estabelecimento Rio Vermelho, próximo ao Forte. Esses estudos constituem dois exemplos práticos, em que se percebe a eficácia do entendimento da arquitetura como um elemento indissociável de toda uma situação política, econômica e social.

\section{História da Arte}

Julgamos conveniente inserir nesta seção a contribuição de alguns autores da história da arte por dois motivos: o primeiro deles é porque vemos a arquitetura além de sua finalidade prática, mas também como um objeto que tem um valor estético, pois carrega uma "intenção" por parte de seus criadores. A questão da intenção será retomada a seguir, ao apresentarmos as idéias de Panosfky a respeito da interpretação das obras de arte. O segundo motivo é porque existe um ramo da história da arte que discute sua relação com a pesquisa histórica, podendo auxiliar, mais adiante, na elaboração de nosssas análises.

Nesse campo iniciamos nossa exposição mencionando o trabalho de Aby Warburg, que tinha como um dos problemas centrais das suas pesquisas a utilização de testemunhos figurativos como fontes históricas. Nesse sentido Warburg dá sequiência à tradição de Jacob Burckhardt, buscando uma história da arte de alcance mais amplo do que o da acadêmica tradicional. Nas mãos de Burckhardt essa pesquisa 
chegou perto da pesquisa histórica propriamente dita, fixando esses objetos em um contexto de conhecimento histórico por meio do estudo meticuloso das fontes escritas. Dessa maneira, Warburg recusava qualquer leitura puramente estética das obras de arte (Forster 1999:28; 54; Ginzburg 2003:56).

$\mathrm{Na}$ introdução da obra de Warburg intitulada: "The Renewal of Pagan Antiquity" Forster (1999:36) afirma que "as perguntas que Warburg começou a fazer a respeito das obras de arte levaram-no além das categorias tradicionais nas quais a história da arte se instalou. Seu interesse se estende para além do cânon da arte elevada, não porque estava cansado dela mas para compreendê-la melhor. Ele considerava que os objetos de arte de uma época não podiam ser comparados com os de outra, não como objetos auto-autenticadores, mas como veículos selecionados da memória cultural". Ao invés de permanecer na esfera da arte elevada, Warburg via os artefatos com os olhos de um etnógrafo, desenvolvendo uma noção que vai além da disciplina acadêmica de história da arte, a de uma disciplina conjunta de "estudos culturais" (Forster 1999:39).

"Como justamente observou C. G. Heise, o objetivo da pesquisa de Warburg era duplo: por um lado, era preciso considerar as obras de arte à luz de testemunhos históricos, de qualquer tipo e nível, em condições de esclarecer a gênese e o seu significado; por outro, a própria obra de arte e as figurações de modo geral deveriam ser interpretadas como uma fonte sui generis para a reconstrução histórica." Nessa perspectiva, a avaliação estética estava ausente. Uma pintura pode ser irrelevante do ponto de vista estético, mas significativa para o historiador, por testemunhar determinadas relações culturais, e também importante para o estudioso iconográfico (Ginzburg 2003:56-57).

Para Warburg, os contornos de uma situação histórica não podem ser dados como lidos, mas reconstruídos a partir de diversos tipos de documentos. Os documentos são importantes na interpretação de Warburg porque eles resistem aos indivíduos, realçando a psicologia individual e suas relações com as instituições sociais (Forster 1999:55). A meta a que Warburg se propunha em suas pesquisas era a compreensão de "uma situação histórica com base em fontes figurativas e documentais" (Ginzburg 2003:57).

Segundo Forster (1999:13), os estudos de Warburg seguem as vicissitudes de sua relação com o estado da arte da pesquisa histórica em sua época. "Eles ultrapassam os horizontes das gerações anteriores em várias direções: em primeiro lugar, se conectam ao estudo de história em geral, e usam um crescente corpo de fontes e documentos; em segundo lugar, em harmonia com a natureza visual dos objetos com os quais lidam, eles correspondem aos primeiros estímulos da psicologia moderna. À luz da psicologia da percepção, os artefatos podem ser vistos isolados de categorias puramente estéticas, e isso confere um interesse totalmente novo à própria arte.“

Um dos assuntos que mais interessou a Warburg, e sobre o qual dedicou diversos estudos, foi o ressurgimento de formas da arte antiga em épocas posteriores. Uma das perguntas centrais da sua obra era: $O$ que significava a Antigüidade clássica para os homens do Renascimento? (Ginzburg 2003:53).

Tanto Warburg quanto os pesquisadores que deram continuidade ao seu trabalho, por meio do Instituto Warburg, exploraram as possibilidades e limites do uso de testemunhos figurados como fonte histórica, utilizando as formas e fórmulas para além do contexto em que nasceram. Ginzburg destaca a importância das pesquisas de Warburg e de outros estudiosos do Instituto para aqueles que, como ele, buscam a integração da morfologia a uma reconstrução histórica. Mas Ginzburg também aponta os riscos que esse trabalho tem de, ao preencher as lacunas da documentação, usar de lugares-comuns inspirados num rígido evolucionismo. Ele ainda destaca a importância do Instituto Warburg, que se dedica ao estudo da continuidade, rupturas e sobrevivências da tradição clássica, assunto que interessa, entre outros, aos historiadores da antigüidade (Ginzburg 2003:9-10; 14; 42). Essas questões, levantadas por Warburg e outros estudiosos do seu Instituto, merecem nossa atenção porque o estudo da permanência das formas arquitetônicas clássicas nas igrejas paleocristãs trata justamente das continuidades e rupturas de 
elementos greco-romanos nas igrejas cristãs, um assunto que foi bastante discutido por esses pesquisadores.

De forma diversa de seu mestre, Saxl, que foi um dos herdeiros da tradição de Warburg, tende a privilegiar a análise iconográfica, até torná-la um instrumento de reconstrução histórica geral. Seu objetivo é "sair dos limites estreitos de uma 'leitura' puramente formalista e considerar a obra de arte singular como uma reação complexa e ativa (sui generis, bem entendido) aos acontecimentos da história circundante" Para Ginzburg, apesar dos resultados obtidos, o método de Saxl não convence, pois ele vê nessa interpretação a possibilidade, por parte do historiador, de ler nos documentos figurados o que já sabe, ou acredita saber, por outras vias. Nesse tipo de interpretação existe o risco de a história da arte ser reduzida apenas a uma disciplina acessória para a produção histórica. Além disso, a postura interpretativa de Saxl se baseia na confiança de que as obras de arte fornecem uma mina de informações de primeira mão, interpretáveis sem mediações sobre a mentalidade e a vida afetiva da época que elas representam. Para Ginzburg (2003:62-63), ver a arte como documento único e exclusivo para interpretação é justamente o ponto problemático dessa postura.

A relação entre dados iconográficos e dados estilísticos, e a relevância deses últimos para os fins de uma reconstrução histórica geral são problemas que ocupam as reflexões de um outro estudioso, Panofsky, um grande amigo e colaborador de Saxl. Esses estudiosos, Saxl e Panofsky, se aprofundam na redescoberta do antigo, e particularmente das "formas" da antigüidade clássica, o que implica na consciência da distância cultural entre passado e presente (Ginzburg 2003:50; 64).

Panofsky foi um dos discípulos de Warburg que após sua morte aprofundou algumas das questões desenvolvidas pelo mestre. Um primeiro aspecto discutido por Panofsky e que merece ser citado é que qualquer conceito histórico baseia-se em categorias de tempo e espaço, isto é: "o cosmo da cultura, e o cosmo da natureza, são uma estrutura espaço-temporal" Assim, "dois fenômenos históricos são simultâneos ou apresentam relação temporal entre si na medida em que é possível relacionálos dentro de um 'quadro de referência' sem o qual o próprio conceito de simultaneidade não teria sentido na história assim como na física." O espaço faz parte desse "quadro de referência' de modo que, se soubéssemos que uma dada escultura negra foi executada em 1510, não teria sentido dizer que se trata de uma obra "contemporânea" ao teto da Capela Sistina, de Michelângelo (Panofsky 1976:26). O que percebemos com esse exemplo dado por Panofsky é que as manifestações artísticas, enquanto parte de uma sociedade, devem ser entendidas num 'quadro de referência' que as localize no espaço e no tempo. Não faria sentido no nosso caso procurar estabelecer conexões entre as igrejas protocristãs e templos construídos na China no mesmo período, porque os espaços em que essẹs edifícios são produzidos não correspondem ao mesmo 'quadro de referência'

Ainda em relação ao conceito histórico, este só pode ser construído com base em monumentos e documentos individuais, ao mesmo tempo em que esses monumentos e documentos só podem ser examinados, interpretados e classificados à luz de um conceito histórico geral. Para Panofsky essa situação não é um beco sem saída. "Cada descoberta de um fato histórico desconhecido e toda nova interpretação de um já conhecido, ou se 'encaixará' na concepção geral predominante, enriquecendo-a e corroborando-a por esse meio, ou acarretará uma sutil e até fundamental mudança na concepção geral predominante, lançando assim novas luzes sobre tudo o que era conhecido antes" Assim, o historiador da arte é um humanista cujo "material primário" consiste nos registros que nos chegaram sob a forma de obras de arte. (Panofsky 1976:29-30).

Panofksy explora o conceito de obra de arte, afirmando que ela tem significação estética, quer sirva a um fim prático e seja boa ou má, o tipo de experiência que ela requer é sempre estético. Os objetos feitos pelo homem e que não exigem experiência estética são chamados de "práticos" Porém os que exigem experiência estética também podem pertencer à categoria dos objetos práticos. A esfera em que o campo desses objetos termina e o da arte começa depende da "intenção" de seus criado- 
res. "Em primeiro lugar, é impossível definir as 'intenções' per se, com precisão científica. Em segundo lugar as 'intenções' daqueles que produzem os objetos são condicionadas pelos padrões da época e meio ambiente em que vivem." (Panofsky 1976:30-32).

O humanista, uma vez que lida com as ações e criações humanas, precisa refazer as ações e recriá-las mentalmente para realizar o seu trabalho. O historiador da arte, que também é um humanista, precisa interpretar seu material com uma recriação estética intuitiva, ao mesmo tempo que submete seu trabalho a uma análise arqueológica racional. Esses dois aspectos: a recriação estética intuitiva e a pesquisa arqueológica são interligadas de modo a formar uma "situação orgânica" Os dois processos não sucedem um ao outro, mas se interpenetram; ambos se qualificam e se retificam mutuamente. A pesquisa arqueológica é cega e vazia sem a recriação estética, que por sua vez é irracional sem a pesquisa arqueológica. Mas, apoiando-se uma na outra, as duas podem suportar um sistema que faça sentido, ou seja, uma sinopse histórica. "A experiência recriativa de uma obra de arte depende, portanto, não apenas da sensibilidade natural e do preparo visual do espectador, mas também de sua bagagem cultural." (Panofsky 1976:34-38).

Panofsky dedicou-se ao estudo da iconografia e da iconologia em obras de arte. A iconografia é o ramo da história da arte que trata do tema ou mensagem dessas obras em contraposição à sua forma. Por sua vez, a iconologia nos é apresentada por Panofsky (1976:54) como "uma iconografia que se torna interpretativa e, desse modo, converte-se em parte integral do estudo da arte, em vez de ficar limitada ao papel de exame estatístico preliminar" A iconologia é, portanto, um método de interpretação que advém da síntese mais do que da análise.

A questão do uso de testemunhos figurados como fontes históricas, que perpassa os trabalhos de Warburg Saxl e Panofsky, também foi abordada por E. H. Gombrich, um estudioso que fez parte do Instituto Warburg. As considerações sobre o problema do estilo o levaram a tomar posições interessantes, ainda que elas não estejam isentas de contradição (Ginzburg 2003:71).
Num ensaio publicado por Gombrich em 1963, ele se coloca contra uma interpretação "fisiognomônica" do caráter não-naturalista da arte medieval. O que ele rejeita não é a existência de tal postura, mas a facilidade, a imediatez do paralelo. "A polêmica criada por Gombrich tem dois objetivos, entrelaçados, mas também distintos (aqui não muito claramente). Em primeiro lugar, a concepção do estilo artístico predominante num período histórico como expressão de uma 'personalidade coletiva hipostasiada' - quase uma 'super obra de arte', executada por um 'superartista', concepção que seria, segundo Gombrich, um resíduo da filosofia romântica da história. Em segundo lugar, a concepção de estilo como "sistema integralmente expressivo' (...) Tal polêmica sem dúvida é muito justa, ao defender o exame específico de cada obra de arte, sem se contentar com 'explicações' muito fáceis e genéricas, que na verdade não explicam nada; mas oculta em si o risco de jogar fora a criança junto com a água do banho, de excluir ou pelo menos afrouxar, nessa recusa do pior historicismo, o vínculo entre fenômenos artísticos e a história" (Ginzburg 2003:74-75).

Gombrich demonstrava uma certa desconfiança em relação à pesquisa dos nexos entre as obras de arte e a situação histórica em que elas nascem, que foi uma das questões principais de seu antecessor, Warburg. Ele não deixa de observar "que existe um "clima mental, uma atitude que permeia sociedades e períodos históricos' cuja arte e artistas reagem inevitavelmente à transformação dos 'valores predominantes"' $\mathrm{O}$ que mais lhe importa nesse assunto é o uso do "estilo" artístico como um índice das transformações sociais ou culturais, o que ele considera bastante problemático (Ginzburg 2003:78).

Em seu livro Arte e Ilusão, Gombrich demonstra, com riqueza de exemplos e fineza de argumentação, que o artista não pode copiar a realidade tal qual ela existe ou como ele a vê. Dessa maneira, a leitura da imagem produzida por um artista constitui um problema, cuja chave para a sua compreensão é a ambigüidade. "Ler a imagem criada pelo artista significa mobilizar as nossas lembranças e nossas experiências do mundo visível e testar essa imagem mediante uma seleção de proje- 
ções" (Gombrich 1995:381). Melhor dizendo, o espectador de uma obra de arte é forçado, com base numa experiência vivida, a escolher entre várias a interpretação correta. São esses fatos psicológicos que explicam o fenômeno da "estabilidade dos estilos na arte" "Não só a 'novidade' de uma mensagem é apreciável apenas se referida a uma tradição, como também a sua própria decodificação pressupõe a existência de um âmbito circunscrito de escolhas - do contrário, ressalta Gombrich, a comunicação seria impossível" (Ginzburg 2003:84-85).

Apesar dos notórios avanços realizados por Gombrich em seus estudos, o problema da modificação do estilo permanece aberto. Mas um aspecto fica bastante claro: a arte tem uma história, e suas várias manifestações não são expressões sem relações entre si, mas anéis de uma tradição (Ginzburg 2003:86).

Para explicar a transformação no estilo em um momento específico da história, a passagem da arte egípcia para a arte grega, o que ele define como "revolução grega" Gombrich introduz um novo conceito: o de "função" Segundo essa idéia, a forma de representação não pode ser separada do seu fim e das exigências da sociedade onde aquela linguagem visual é válida. $\mathrm{E}$ assim, para Gombrich as grandes mudanças do gosto explicam-se pela modificação das "exigências", que por outro lado nunca parecem ditadas por motivos meramente estéticos (Ginzburg 2003:89-90). Dessa maneira, mesmo que Gombrich não ressalte esse aspecto, vemos que a questão da mudança do estilo está intrinsecamente ligada às transformações sociais, políticas e culturais, e conseqüentemente, à história.

Ginzburg coloca que a orientação imprimida por Gombrich em suas pesquisas, dirigindo-se à tradição fundada por Warburg implica em um ganho e uma perda. Por um lado um ganho com o aprofundamento dos problemas do estilo pictórico por meio dos instrumentos oferecidos pela psicologia e por outro uma perda com o reduzido interesse pela relação recíproca entre os vários aspectos da realidade histórica e os fenômenos artísticos (Ginzburg 2003:88).
Ainda no campo da arte, algumas questões levantadas por Baxandall em sua obra: Patterns of Intention merecem ser citadas aqui. Esse livro procura explorar a dimensão histórica das obras de arte usando da psicologia. Mesmo tendo um de seus capítulos direcionado para o entendimento de um elemento arquitetônico, no caso, uma ponte, a sua maior preocupação são as obras-de-arte, mais especificamente a pintura, onde, por meio de alguns exemplos, ele procura entendê-las pela psicologia e pela história. Ainda assim, os questionamentos apresentados por Baxandall no seu livro se mostram úteis aos nossos propósitos de estudo de uma forma arquitetônica.

Um primeiro aspecto de interesse que Baxandall levanta é sobre a diferença entre ver uma pintura e descrevê-la. $\mathrm{O}$ aspecto da linguagem foi discutido anteriormente, no item 2.1, quanto à arqueologia, mas acreditamos que vale a pena apresentar os argumentos desse autor a respeito, que tornam seu entendimento mais claro. "De fato, a linguagem não é bem equipada para oferecer uma notação a respeito de uma pintura em particular. É uma ferramenta generalizante." Além disso, é difícil evitar na descrição de uma pintura uma reorganização tendenciosa, simplesmente por mencionar um elemento depois do outro. Além disso, alguns dos termos usados na descrição não serão diretos, na medida em que eles referem-se primeiramente não à pintura propriamente dita, mas ao efeito que ela nos causa (Baxandall 1985:3;11). Mais adiante, o autor destaca que, dos cinco sentidos, a visão é o mais precioso e o que atinge a mente com mais força, mais exato que a audição, no sentido de que ela nos traz o mundo. A visão retém mais coisas que a audição, e as coisas vistas aderem à mente melhor do que as ouvidas (Baxandall 1985:43-44). As questões a respeito dos limites da descrição e o potencial da visão, mencionados por Baxandall no caso da pintura, também podem ser aplicados na arquitetura, porque a entendemos como uma manifestação artística.

A teoria de explicação histórica da arte tende a se dividir em dois campos - o nomológico (ou nomotético) e o teleológico (ou 
idiográfico). De um lado, os nomológicos argumentam que é possível, em princípio, explicar as ações históricas humanas dentro de termos causais bastante estritos, como os exemplos que são cobertos por leis gerais. Do outro lado está a tradição teleológica, que declina o modelo de ciências físicas e reconstrói o propósito do autor com base em fatos particulares mais do que os gerais.

No caso de Baxandall (1985:12-13), seu interesse como historiador ou crítico é na maioria das vezes idiográfico, no sentido de localizar e entender as peculiaridades individuais. Assim, sua energia e seu interesse são direcionados mais para o estilo teleológico, em oposição ao tipo de explicação nomológica, que vai primeiro em direção à generalização, a fim de identificar as leis gerais sob as quais as performances individuais podem ser levantadas. Ele reflete sobre até que ponto somos capazes de penetrar na estrutura intencional dos pintores que viveram em culturas ou períodos remotos aos nossos. Junto a isso está a questão de até que ponto podemos validar ou verificar nossas explicações (Baxandall 1985:105).

"As culturas não impõem um aparato cognitivo e refletivo aos indivíduos. As pessoas diferem em suas experiências de trabalho, por exemplo. (...) Em qualquer época os pintores também têm formas especiais de ver, e isso está poderosamente em jogo nas pinturas. Mas as culturas também facilitam certos tipos de desenvolvimento cognitivo em grande parte de seus membros. Vivendo em uma cultura, crescendo e aprendendo a sobreviver dentro dela, nos envolve em um treinamento perceptivo especial. Dota-nos de hábitos e habilidades de discriminação que afetam o modo como lidamos com a nova informação que uma sensação oferece à mente" (Baxandall 1985:107).

Para entender a relação que o pintor estabelece com a sua cultura, Baxandall recorre à teoria econômica e ao conceito de "mercado" "Um mercado é o contato entre produtores e consumidores de bens com o propósito de troca. É um modelo de relação na qual dois grupos de pessoas estão livres para fazer escolhas, e na qual elas interagem entre si. Tipicamente, isso envolve um grau de competição entre ambos, tanto produtores quanto consumidores, entre os quais há um meio de comunicação não-verbal: partes de cada um dos lados podem fazer balanços, participando ou se abstendo." A essência de tudo isso é que há uma escolha de cada lado, e qualquer que seja o lado tem consequiências para a ordem das escolhas para ambos os lados (Baxandall 1985:47). O que o autor procura discutir ao apresentar esses conceitos é até que ponto podemos pensar, tendo um propósito crítico, sobre as relações entre o interesse visual das pinturas e um pensamento sistemático, científico ou filosófico, da cultura da qual elas provêm.

\section{Contribuições das disciplinas para o estudo das igrejas paleocristãs}

A partir das vertentes metodológicas apresentadas nos ítens anteriores, procuramos discutir e evidenciar todas as contribuições que elas podem oferecer para o nosso objeto de estudo, que são as igrejas construídas na região da Palestina entre os séculos IV e VI d.C., os primeiros edifícios construídos para esse fim em um momento que o Cristianismo passa a ser a religião oficial do Império Romano. Essas igrejas são entendidas como um objeto arqueológico por serem produtos culturais, elementos ativos carregados de conotações simbólicas, que interagem de forma dinâmica com a sociedade que os criou; como uma forma arquitetônica, por serem resultado da ação humana sobre o espaço, carregando em si informações que são "lidas" pelos indivíduos que fazem uso do ambiente construído que ela cria, e como obra de arte, por serem objetos carregados de intenção, que trazem em si não só a visão de mundo do seu autor, mas do ambiente cultural e social onde eles se inserem.

Nossas intenções com esse estudo podem ser traduzidas sob a forma de uma pergunta, a mesma que Heinrich Wölfflin faz em 1886 ao iniciar sua dissertação sobre Psicologia da 
Arquitetura: "Como é possível que as formas arquitetônicas sejam capazes de expressar emoção ou estado de espírito?" (Forster 1999:13)

Acreditamos que compreender o espaço construído como uma linguagem, um conjunto de códigos que pode ser lido é um método eficiente para se entender a sua dinâmica, uma vez que se conheça esse código. A arquitetura é sim uma forma de linguagem, e por meio dela idéias e concepções de mundo podem se expressar. O importante é compreendê-la como uma forma de comunicação não-verbal, que, como Umberto Eco e Baxandall destacam, por também possuir funções não-lingúísticas, torna-se mais difícil de ser interpretada. A dificuldade de traduzir a arquitetura, assim como qualquer outra manifestação artística, em linguagem verbal ou escrita é que a descrição se torna generalizante demais e certas particularidades da obra se perdem nessa transposição.

A metodologia que nos permite realizar uma interpretação de estruturas presentes na linguagem arquitetônica, que muitas vezes não estão visíveis, consiste em entender as mudanças na arquitetura dentro de um modelo de comunicação não-verbal.

Para que possamos produzir a análise de uma forma arquitetônica que faça sentido, Panofsky alerta que não devemos nos desvencilhar de dois aspectos: a recriação estética e a pesquisa arqueológica, que se interpenetram e se retificam mutuamente (Panofsky 1976:36).

Dos estudos de Gombrich, o aspecto mais importante que devemos ter em mente é a questão da "estabilidade dos estilos na arte" que coloca a questão da tradição, de elementos que são mantidos apesar das inovações, de modo a manter alguma referência de experiências anteriores a fim de que o espectador seja capaz de estabelecer uma comunicação com a obra de arte (Ginzburg 2003:84-85). Como veremos mais à frente nesse texto, essa questão da tradição, colocada por Gombrich, é algo que será tratado em maior profundidade, quando interpretamos a questão da permanência das formas clássicas nas igrejas que configuram o nosso objeto de estudo.

Assim como Ginzburg colocou, também buscamos nesse trabalho a integração da morfologia a uma reconstrução histórica, conscientes do cuidado que devemos tomar para não cair no evolucionismo ao procurar preencher lacunas que apareçam na documentação. Também reconhecemos o valor dos trabalhos publicados pelo Instituto Warburg, que caminham nesse sentido ao apresentarem estudos a respeito da continuidade, rupturas e sobrevivências da tradição clássica, tema que será abordado nesse trabalho (Ginzburg 2003:14).

É interessante antes do início de nossas análises retomarmos o modo como Baxandall descreve a relação do pintor com a sua cultura. Podemos entender suas colocações de uma forma mais abrangente, substituindo o termo "pintor" por qualquer artista que produza uma obra de arte, inclusive os arquitetos, sem que o sentido de suas afirmações seja esvaziado. Baxandall compara a relação entre o artista e sua cultura como um mercado, onde eles interagem e são livres para escolher o que levam e o que deixam a partir desse contato (Baxandall 1985:47). Acreditamos que o modo como essa relação é explicada aqui é essencial para se entender a questão da permanência e da mudança de uma forma em um espaço temporal e culturalmente definido. Especificamente no nosso caso foi possível perceber que, com o estabelecimento de um novo edifício, no caso as igrejas, existiu uma interação com as formas do passado, que resultou na permanência de alguns elementos, mas também ocorreram inovações. Mas, no nosso exemplo, como será explorado nos próximos capítulos, não houve liberdade para escolher o que se mantinha do passado.

Os edifícios religiosos cristãos, construídos em grande número durante a Antigüidade tardia, tomam o lugar dos edifícios pagãos, por vezes construídos no mesmo local onde antes havia um templo; as igrejas podiam assim substituir os templos sem que a estrutura da cidade fosse alterada. Nessa situação vários aspectos devem ser levados em conta, tais como: o tipo de edifício que as precedeu, as circunstâncias pela qual o edifício anterior foi destruído, sua ligação com o traçado das ruas. Tais indicações podem ser tão importantes quanto a data da construção e o local onde essas igrejas 
são erigidas. A construção de igrejas representa uma fonte de benefícios e deve ser considerada um investimento (Spieser 1986:52), entendida não apenas sob o aspecto econômico, mas como algo que abrange também as esferas ideológica e cultural dessa sociedade em transformação. Em outras palavras, não se trata de uma questão de fé ou de mentalidade, mas de interesses importantes que estão em jogo. Procuramos aqui discutir de que maneira podemos interpretar essas igrejas como um veículo de mudança em si e como entender a situação sociopolítica, econômica e cultural que existe à sua volta.

Como estruturas arquitetônicas que podem ser entendidas como uma forma de comunicação não-verbal, as igrejas protocristãs expressam na sua forma o modo de vida da sociedade que as criou. Percebemos assim que o cristianismo, entendido como o desenvolvimento de uma nova crença, acarreta modificações nos costumes e nas mentalidades, que manifestam-se materialmente nas formas construídas, introduzindo elementos novos e adaptando ou reaproveitando os antigos.

Procurando um sentido mais amplo, além do material, e vendo esses edifícios também como espaço de sociabilidade, percebemos que eles provocam uma determinada reação no indivíduo que faz uso dele. Vale ressaltar a contribuição que os estudiosos da área de arqueologia trazem para nós sobre a importância do contexto em que o objeto material se insere, e como o conhecimento de toda uma situação nos auxilia na leitura dos objetos materiais, como no caso do nosso material de estudo. Adotando a análise contextual, notamos que as igrejas expressam por meio de suas formas aspectos das relações de poder que se desenvolvem em época Bizantina. Esse tipo de leitura nos faz perceber que a adoção da forma de basílica não é gratuita. Ao escolher o cristianismo como religião oficial do Império Romano, a partir de Constantino, o Imperador passou a ser soberano por direito divino, concentrando na sua pessoa os poderes político e espiritual. Essa ligação entre os poderes secular e religioso é expressa nas primeiras igrejas cristãs, que se configuram sob a forma de basílica - um edifício civil da tradição romana, reproduzindo no espaço construído as relações de poder e a vida social da civilização da qual fazem parte. Devemos entender a construção das primeiras igrejas católicas como elementos que organizam e disciplinam o espaço sob essa nova ordem, que a partir do século IV d.C. será adotada por grande parte dos imperadores romanos.

O trabalho de autores como Duncan (1990) e Monks (1992) nos faz perceber que as igrejas paleocristãs podem expressar em suas estruturas aspectos das relações de poder, a começar pela sua forma, inspirada na basílica, um tipo de edifício romano ligado ao governo e administração imperiais, e que não mantinha nenhuma relação com os edifícios religiosos clássicos. Como no período bizantino a religião esteve muito ligada ao poder imperial, o tipo de leitura que estudiosos como Duncan e Monks se propõem a fazer com relação ao uso do espaço em seus objetos de estudo - o reino Kandy no primeiro caso e o Forte Garry no último - pode se mostrar bastante proveitoso para o estudo de igrejas bizantinas.

Por outro lado, não compartilhamos das idéias de Zarankin no que diz respeito à compreensão de uma forma arquitetônica como veículo de expressão de poder, porque esse autor, ao entender a arquitetura como uma tecnologia de poder, um instrumento disciplinador, evidencia de modo exagerado um choque entre grupo dominante sobre grupo dominado. As colocações feitas por Zarankin (1999) podem, em nossa opinião, sugerir a mudança da forma arquitetônica como a materialização de uma luta de classes, carregando a arquitetura de um sentido que não lhe pertence, fora em algumas situações bem determinadas no espaço e no tempo. O tipo de análise que esse autor propõe nos parece bastante limitado, pois ele reduz toda a complexidade das relações de uma sociedade que se materializam nos edifícios a um jogo de poder entre grupos dominantes e dominados.

Em grande medida, o que essas mudanças formais que propomos apresentar nesse trabalho indicam é que a forma de pensar da sociedade que produziu essa transformação não é mais a mesma, e responde materialmen- 
te a uma nova mentalidade. Na passagem para o período bizantino houve nos indivíduos uma mudança de mentalidade: eles se despojaram de certos valores para adotar outros em seu lugar. Para vários autores que lidam com a questão do espaço construído, como Perring (1991), Rapoport (1982) e Duncan (1990), e como já mencionamos, o desenho do ambiente faz parte de um processo de informações codificadas, onde a tarefa de seus usuários é decodificá-las; e isso só ocorrerá da maneira esperada se o indivíduo que usa o espaço conhecer o código que é utilizado. $\mathrm{O}$ espaço arquitetônico é organizado para obter respostas específicas, daí temos que as mudanças em sua ordenação acompanham as transformações sociais. É isso que essa mudança formal reflete.

Assim, o campo da arqueologia, mais especificamente a área da arquitetura, pode trazer contribuições à esse trabalho por sua maneira de ver as construções como produtos culturais que estabelecem uma relação dinâmica com o homem. Nesse campo nos alinhamos aos estudiosos que entendem a produção da arquitetura sob duas ópticas: a "teórica" que considera que as visões de mundo influem na concepção de um edifício e a "prática", que vê a arquitetura de uma maneira funcional, como resposta lógica às necessidades naturais humanas. Os arquitetos também entendem o ambiente construído sob essas duas ópticas: de um lado a interpretação da forma pela sua funcionalidade, observando se ela atende às necessidades humanas e de outro a análise mais voltada aos aspectos da relação entre a cultura e a interação do indivíduo com o espaço. Nas idéias de Rapoport (1982), as quais partilhamos, vemos uma convergência entre essas duas idéias. As áreas da arquitetura e da arqueologia também mostram uma congruência de idéias na medida em que entendem a forma arquitetônica como um tipo particular de linguagem, com uma dinâmica própria. Estudiosos de ambas as áreas entendem o ambiente construído como uma forma de comunicação não-verbal, que carrega códigos de comportamentos que devem ser entendidos por aqueles que fazem uso do espaço. Consideramos a apresentação da arquitetura como uma forma de comunicação não-verbal, com uma dinâmica própria, como uma grande contribuição dessas áreas para o desenvolvimento desse trabalho. Os artigos escritos por Duncan (1990) e Monks (1992) mostraram-se valiosos por apresentarem dois estudos práti$\cos$ nos quais se vê o uso de estruturas arquitetônicas, enquanto formas de comunicação nãoverbal, como elementos importantes para o entendimento de situações políticas, econômicas, sociais e culturais; no caso de Duncan são exploradas as questões das relações de poder no uso do espaço no reino Kandy e com Monks vemos de que maneira a situação econômicosocial está intimamente ligada às mudanças na arquitetura no Forte Garry.

Considerando a arquitetura não apenas pela sua finalidade prática, mas também como um objeto de valor estético, buscamos na área da história da arte mais algumas ferramentas interpretativas. Encontramos nas idéias apresentadas por Warburg e de outros membros da escola de pensamento que foi criada a partir dele questões interessantes a respeito da relação da produção artística com a pesquisa histórica, que julgamos pertinentes para a discussão aplicada ao nosso objeto de estudo. Os autores dessa área que foram estudados vêem as manifestações artísticas, e aqui incluímos a arquitetura, como objetos que têm linguagem própria. Eles não definem a arte como uma forma de comunicação não-verbal, mas as idéias que apresentam vão ao encontro do que havíamos visto com os estudiosos das áreas de arqueologia e arquitetura na forma como entendem a arte: com dinâmica própria. Mas, por outro lado, os estudiosos de história da arte exploram dois pontos que não foram tão evidenciados nas áreas de arqueologia e arquitetura e que se mostraram importantes no processo de elaboração desse trabalho. O primeiro deles é a questão da transposição para a linguagem que fazemos quando descrevemos uma obra de arte, e as dificuldades inerentes a essa mudança de linguagem. $\mathrm{O}$ outro ponto diz respeito ao uso da arte na pesquisa histórica. Esses estudiosos defendem o uso das manifestações artísticas como parte integrante do contexto histórico e não como uma mera ilustração. É assim que entendemos essas igrejas, em todos os momen- 
tos da elaboração dessa dissertação. Não como meras imagens do momento de mudança que se configura entre o final da antiguidade e o início da Idade Média, mas como parte integrante de todas as transformações vividas nesse período.

Mais do que traçar um histórico individual das igrejas pesquisadas, parece-nos mais interessante fazer um exercício de leitura de sua arquitetura. Utilizando ferramentas conceituais para interpretação arqueológica de arquitetura, procuramos identificar de que maneira elas podem ser vistas como estruturas de poder, tendo cuidado para compreender toda a sua complexidade e amplitude, evitando ver as situações que as igrejas nos revelam a partir da perspectiva limitada da luta entre dominante e dominados, como faz Zarankin (1999). Como já foi discu- tido anteriormente, a arquitetura, como um tipo de comunicação não-verbal, tem sua própria estrutura sintática, e o desafio dessa investigação é conseguir transformar edifícios em textos possíveis de serem decodificados e interpretados.

A partir desse embasamento metodológico procuraremos entender o nosso objeto de estudo, as igrejas proto-cristãs como uma problemática, porque sua construção e organização espacial trazem informação relevante sobre a sociedade a que pertencem. Procuramos com esse trabalho decodificar essa forma de linguagem não-verbal que constitui a arquitetura, buscando ultrapassar sua interpretação formal para dar voz à sociedade que a produziu, apresentando-a de maneira acessível a todos que tenham interesse em conhecê-la. 



\section{2 - $O$ estabelecimento do cristianismo no Império Romano}

$A$ representou um período da História onde a região do Mediterrâneo constituiu uma unidade. A primazia romana durou aproximadamente sete séculos, a partir do fim do século III a.C. até o colapso da parte ocidental deste império, no século V d.C. Roma, ao dominar a mecânica de interação entre grande quantidade de lugares ao longo da costa e das ilhas deste mar, foi a única a atingir êxito entre os vários povos que tentaram essa realização, como os cartagineses, os ptolomeus, gregos e venezianos, entre outros. Dessa maneira, o sucesso de Roma parece espetacular pela sua amplitude e duração. A idéia de que o Mediterrâneo é o berço da cultura clássica é uma de suas imagens mais marcantes, que nasceu da hegemonia de Roma e da imposição de valores e ideologia de uma elite greco-romana (Horden e Purcell 2000:23;25).

Ao dominar a região do Mediterrâneo esse Império integrou politicamente um verdadeiro mosaico de civilizações, que abrangia uma área que chegava até à Escócia ao Norte, Portugal a Oeste, Aswan ao Sul e Palmira a Leste. Por vários séculos, a população da chamada Terra Santa foi exposta ao processo sociopolítico da "romanização". que deixou claras manifestações nos vestígios arqueológicos dessa época (Levy 1995:446). O domínio de Roma sobre o Oriente Próximo se iniciou na década de 60 a.C., com a chegada das forças de Pompeu à região, e alcançou sua maior extensão no final do século III d.C. Antes dos romanos a região foi conquistada por Alexandre da Macedônia, que lá estabeleceu a dinastia Selêucida no século IV a.C., período em que foram fundadas várias cidades e estabelecimentos gregos e que o uso da língua grega foi difundido na região (Millar 1993:2).

A presença romana afetou de várias maneiras a arquitetura de toda a Palestina. O impacto romano consolidou os estilos de arquitetura helênica que proliferaram pela parte Leste do Mediterrâneo antes da conquista. As inovações trazidas pela arquitetura romana foram usadas em todo o território da Palestina. As mais freqüentes eram os banhos, presentes nos palácios e casas herodianas, mas também tecnologias construtivas, como domos, arcos e abóbadas, pontes e escadas, que foram incorporadas e usadas na construção de edifícios nessa região. Esses elementos podem ser encontrados na reconstrução do Segundo Templo em Jerusalém e nos palácios herodianos de Herodium, Jericó e Massada, bem como em inúmeras localidades (Levy 1995:455).

Atualmente, a declaração de que existiu uma cultura Mediterrânica homogênea com o domínio dos romanos começou a ser desafiada pelos historiadores da antigüidade. Realmente, sob o ponto de vista cultural, o Império Romano abrigou e conviveu com uma grande diversidade de culturas, mas não se pode negar que, sob os aspectos político e econômico, os romanos unificaram o Mediterrâneo. Os autores Horden e Purcell entendem o Mediterrâneo como um paradoxo entre a unidade e a fragmentação, pois para eles essa parece ser a chave para o entendimento das relações que se travam nesse espaço (Horden e Purcell 2000:24-25). Procuraremos ter esses aspectos em mente ao estudarmos a região da Palestina no período de dominação romana, pois ela está inserida na situação apresentada pelos autores.

\section{Mecanismos de organização do Império Romano - as cidades}

As cidades foram um importante mecanismo para a expansão do Império Romano e por isso seu desenvolvimento foi encorajado na maior parte do tempo em que ele durou. A 
maneira como foram administradas foi essencial para o funcionamento do seu sistema político, contribuindo para que tal império atingisse as proporções que alcançou, abrangendo toda a região que envolve o Mar Mediterrâneo (fig. 1). De fato, o Império Romano foi uma aglomeração de cidades, muitas delas antigas, como Atenas, Éfeso, Antióquia, Alexandria, comunidades autônomas que eram responsáveis pelas áreas que ocupavam, seus territórios. Constitucionalmente e administrativamente as cidades eram as células que compunham o Império. Geograficamente, o mapa desse império era um mosaico de territórios de cidades.

Antes de nos aprofundarmos no estudo específico do desenvolvimento das cidades nas colônias do Império Romano na região do Oriente Próximo, julgamos conveniente intro-

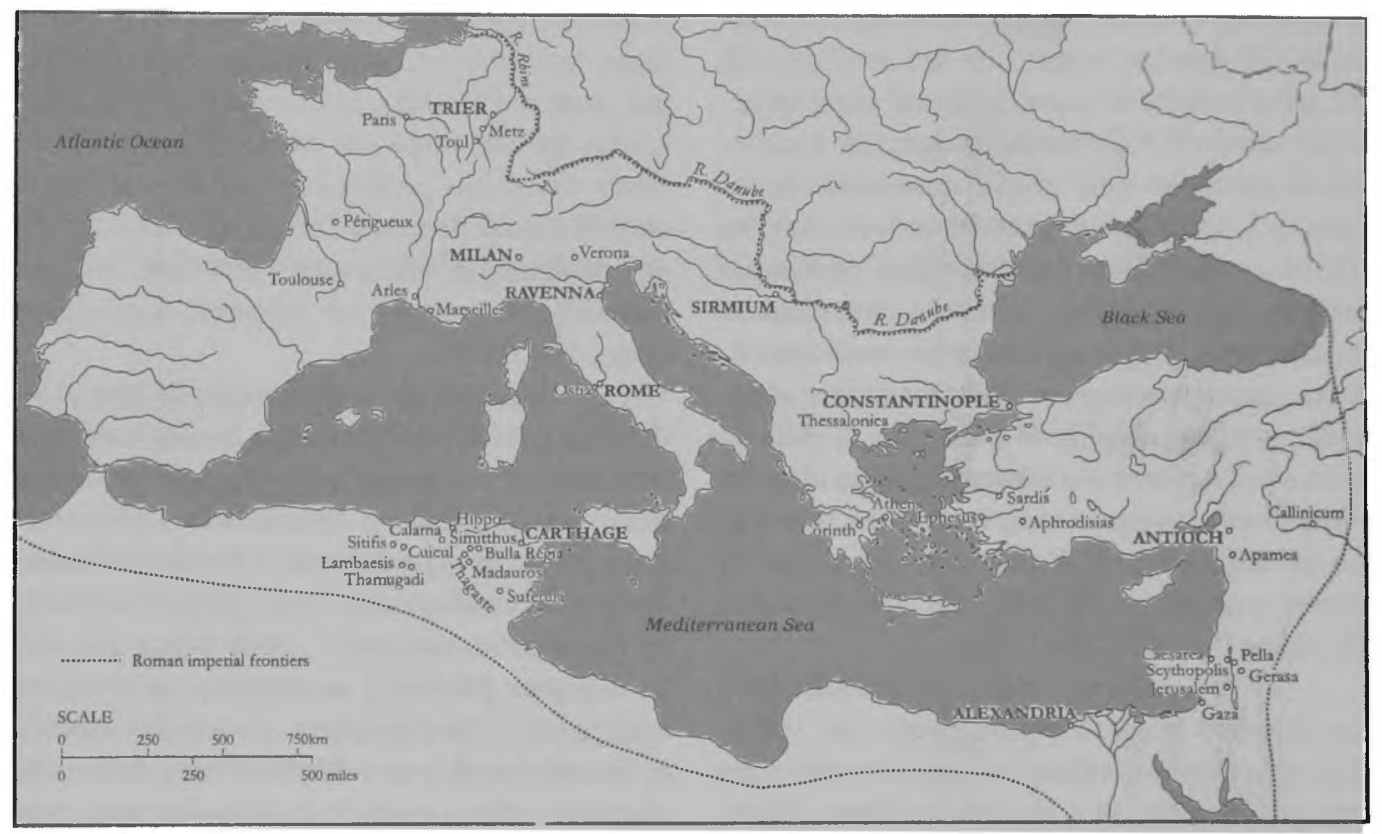

Fig. 1 - Mapa geral do Império Romano na $2^{a}$ metade do século I d.C., com a localização das principais cidades.

Fonte: CAMERON, A. e GARNSEY, P. (ed.) The Cambridge Ancient History - volume XIII: The Late Empire, A. D. 337-345, p. 372.

duzir, mesmo que de maneira superficial, a reflexão desenvolvida por Horden e Purcell sobre o que foi a cidade na Antigüidade, presente em sua obra sobre o Mediterrâneo. Ao tratar da cidade, os autores procuram entender suas relações com o ambiente na qual ela se insere. Tendo como referência o capítulo da autoria de Weber, intitulado "A dominação não legítima (Tipologia das Cidades)" Horden e Purcell nos mostram que qualquer definição de cidade contém elementos

1 O capítulo citado faz parte da obra póstuma de Weber, intitulada Economia e Sociedade. arbitrários, isto é, determinados por aqueles que se propõem a estudá-la em profundidade. Como alternativa a esta perspectiva limitadora, tais autores se propõem a entender as comunidades do Mediterrâneo a partir de um ponto de vista mais amplo, o das microecologias e da interação entre elas (Horden e Purcell 2000:53; 98). Ao adotarmos esse ponto de vista, vemos que as cidades antigas se expandem, se diluem na sua relação com uma área mais ampla, e questionamos se é possível chegar a uma definição de cidade. Observamos que, quanto mais procuramos características em comum, cada vez 
mais vemos quão diferentes são as cidades entre si, ao menos em sua aparência física, inseridas na paisagem das mais diversas maneiras. Um ponto que elas têm em comum são os tipos de relações que se travam em seu espaço, dentro de um recorte temporal preciso. Com essa reflexão, passaremos a estudar as cidades da região da $\mathrm{Pa}$ lestina durante o período em que eram parte do Império Romano.

Autores como Millar ressaltam o papel essencial da cidade para o Império Romano, destacando aspectos importantes dessa relação. Em sua obra sobre o Oriente Próximo Romano, Millar considera o papel central das cidades um fato inegável, sejam elas fundações de período Helenístico ou cidades antigas, como Damasco ou Tiro. $\mathrm{O}$ autor destaca ainda que, durante o período de três séculos que separa as conquistas de Alexandre da dominação romana na região, muitas cidades tornaram-se cidades gregas, e essas transformações continuam durante o período de dominação romana. Dessa maneira, o que os romanos encontraram quando chegaram ao Oriente Próximo não era uma estrutura urbana totalmente "nativa" ou "oriental" uma vez que os contatos anteriores com a cultura helênica grega originaram uma nova forma e organização das cidades, onde elementos da cultura e da estrutura social antigos contrastavam com estruturas importadas do ocidente. As complexas relações de propriedade, as transações privadas encaminhadas com o uso de documentos em grego e trocas diretas com representantes do Estado fornecem elementos que nos permitem entender como a vida se desenrolava nas cidades dessa região (Millar 1993:18-19).

O sistema de domínio utilizado pelo Império Romano foi uma reminiscência daquele praticado pelos reis macedônicos, adaptando a cidade-Estado independente a um papel de dependência estratégica. Jones destaca Alexandre como o rei que iniciou a tradição de fundar cidades, tradição essa que permaneceu forte durante o Império Romano, principalmente na sua parte oriental (Jones 1986:718-719). Como os macedônicos, e de forma diversa da adotada pelas cidades gregas, os romanos não foram totalmente exclusivos, e em circunstâncias favoráveis ou quando desejavam, eles estendiam sua cidadania, incorporando novos membros, desta forma criando uma fusão entre homens de poder, o que se tornou uma de suas maiores forças (Tomlinson 1992:10).

"Para os imperadores romanos as cidades serviam a um propósito administrativo distinto, isentando as autoridades centrais da responsabilidade da administração local, difícil de se coordenar centralmente, mesmo com as comunicações aperfeiçoadas criadas pelos romanos. Eles proporcionaram uma organização acessível para uso financeiro, e garantiram lealdade local ao sistema imperial, sob condições normais" (Tomlinson 1992:11). O império podia operar com um serviço civil e relativamente barato porque o governo central delegava aos magistrados da cidade e ao conselho, que não eram pagos, a maior parte do trabalho cotidiano (Jones 1986:11-12). A cidade se mostrou tão vantajosa dentro dessa estrutura que o sistema foi ampliado. Além de centro administrativo elas eram muito valorizadas pela população local por proporcionar as amenidades da civilização por meio de seus equipamentos públicos.

No campo da religião, ao se estabelecer nos territórios conquistados, Roma não procurava erradicar as "tradições religiosas nativas" e nem impor sua própria tradição religiosa. Ao observarmos o Império Romano sob esse aspecto, percebemos que houve um intercâmbio em vários níveis entre os cultos romanos e as práticas religiosas do império. Apesar dele não impor o seu próprio culto nem remover os cultos tradicionais de suas colônias, um dos aspectos da integração era particularmente importante dentro da vasta extensão geográfica e política do Império Romano: a cidadania romana. Dos portadores dessa cidadania era esperado que reconhecessem os deuses romaros. Por outro lado, as províncias não eram Roma propriamente dita, e as regras que guiavam a prática religiosa em Roma não eram aplicadas diretamente em qualquer lugar desse império. Assim, a prática da religião da capital nas colônias sempre foi um processo criativo, envolvendo adaptação e mudança. Dessa maneira, no mundo romano havia várias imagens diferentes da religião "romana" (Beard 1998:317-320;337).

Durante o Império Romano a configuração das cidades usou o que Perring chamou de estratégia de inclusão, isto é, a ordem social 
foi incentivada pela identificação do interesse da comunidade no espaço urbano. A configuração física dessas cidades, pelos seus pórticos, praças e ruas de traçado regular, mostra que os visitantes são esperados e bem-vindos em seu espaço (Perring 1991:274-276).

Os edifícios públicos eram o cenário da exposição cultural do poder e da comunidade, demonstrando tanto o papel da elite quanto o próprio orgulho da cidade, sua preeminência no seu território e o seu lugar em um mundo mais amplo. A função desses edifícios não era num primeiro momento, preencher a necessidade de assentos no teatro, ou criar mercados, mas antes disso, faziam parte do comportamento cultural da elite curial romana (Whittow 1990:6-7). Usando os conceitos de Rapoport, o espaço das cidades greco-romanas e bizantinas constituíam uma forma de comunicação não-verbal, capaz de ser decodificada e compreendida pelos indivíduos que viviam nesse universo cultural e produzindo neles efeitos diretos e indiretos, limitando e estabelecendo relações, que resultaram em um comportamento adequado às exigências desse sistema.

O conselho (curiales) era efetivamente o corpo governante da cidade, uma entidade associativa, cujos membros, os decuriões, tinham posição vitalícia e hereditária. Apesar de constituir uma única classe em nível político, o conselho abrangia uma vasta extensão social e econômica. O tamanho desse conselho variava bastante, de acordo com o tamanho da cidade.

As qualificações exigidas para se tornar um membro desse conselho eram: ser originário ou morar na cidade em questão; ter nascido livre; e ter propriedades, normalmente terras. A quantidade mínima de propriedades que um homem devia ter para ser admitido no conselho variava de cidade para cidade, mas tal restrição permitia que somente os membros das aristocracias locais estivessem aptos a participar desse conselho. Para os imperadores os decuriões eram, como Majoriano colocou: "o sistema nervoso do Estado e os corações das cidades" Vale ressaltar que a elite que fazia parte do conselho não existia isolada em seu local, e deve ser vista como parte de uma rede de relacionamentos mais ampla, ligando cidades e províncias, unindo-se por sua vez ao governo imperial.
Eram as autoridades locais, representadas pelos conselhos, que coletavam e provavelmente estimavam o tributo e faziam as cobranças; selecionavam os recrutas para o exército, faziam a requisição de suprimentos, roupas e transporte militares; eles também eram responsáveis pela manutenção das estradas e pontes, pela administração do correio público, pelo fornecimento de animais caso fosse necessária sua substituição e da hospitalidade necessária aos representantes imperiais. Como "corações das cidades", esses conselhos eram responsáveis por manter as facilidades da vida urbana, particularmente os banhos e os jogos, que aos olhos dos romanos eram essenciais para uma vida civilizada (Jones 1986:748).

O entretenimento público merece ser destacado por ser o encargo mais pesado para as cidades. "Até o século VI as cidades mantiveram a tradição de promover jogos - corridas com carros, competições atléticas, peças teatrais e lutas entre feras selvagens. Algumas cidades coletavam doações (agonotheticae possessiones) para este propósito, mas o maior volume de gastos recaía nos decuriões" (Jones 1986:736).

Para Jones, uma parcela significativa dos membros dos conselhos ficou empobrecida depois de arcar com os onerosos custos de manter todas as amenidades exigidas em uma cidade civilizada, como os entretenimentos públicos, e assim, fora alguns casos excepcionais, deixaram de ser pessoas ricas e influentes o que acarretou o declínio da autonomia local (Jones 1986:737-757). Para esse autor, o declínio das cidades tem relação direta com o declínio dos conselhos.

A perda de autonomia das cidades é vista de uma outra maneira por Tomlinson, que detecta no século III d.C. um declínio geral da riqueza, tanto local quanto imperial. Para esse autor isso se deve ao elevado custo de se repelir a crescente pressão de inimigos externos, o que tornou o peso da administração das cidades intolerável. No século seguinte, quando uma condição de estabilidade voltou, o mundo romano havia mudado, e nesse momento as cidades conformaram-se dentro de um sistema mais centralizado e aristocrático, simbolizado pela grande cidade, Constantinopla - a nova Roma, 
assento da administração imperial (Tomlinson 1992:12). Pouco depois do estabelecimento de Constantinopla como capital o Império Romano foi dividido, a fim de fortalecer a sua administração.

Para Whittow, interpretar o declínio dos conselhos como equivalente à ruína das cidades e a impotência de suas elites, como Jones faz, é errôneo. Pela forma como ele interpreta os fatos, também a construção de Tomlinson, que associa o declínio dos curiales à pressões dos inimigos externos não está correta. Sua argumentação baseia-se na evidência de que as cidades romanas, pelo menos no Oriente Próximo, continuaram a prosperar nos séculos VI d.C. e até mesmo, em alguns casos, vão além do século VII d.C., apesar do declínio e desaparecimento dos conselhos. Pella é um exemplo disso. Ela já era uma cidade antiga no período romano, mas pouco material dessa época sobreviveu, porque foi destruído por um novo desenvolvimento no período romano tardio. Novas casas, igrejas, banhos e colunadas testemunharam a riqueza e a cultura urbana da cidade que permaneceu durante o século VI d.C. e não se interrompeu nos séculos VII e VIII d.C. (Whittow 1990:12-16).

\section{A arquitetura romana e suas técnicas construtivas nas colônias do Império}

Vários autores relatam que entre as cidades do Império Romano, principalmente na parte oriental, havia grande competitividade, materializada em seus edifícios públicos: banhos, ginásios, templos (inclusive para o culto imperial), estádios, stoas, ágoras, teatros e arcos monumentais e nos jogos. A rivalidade entre as cidades era muito acirrada - o que uma delas tinha, a outra queria maior e mais sublime. Essa extravagância nas construções, característica das cidades do império, era patrocinada pelas aristocracias locais. De qualquer maneira, a extensão e a escala dos serviços municipais variava, naturalmente, de acordo com o tamanho e riqueza da cidade, mas não era raro ver uma cidade sobrecarregada com os enormes gastos aplicados nessas amenidades, os quais ela era incapaz de sustentar. Por outro lado, existiram até mesmo cidades que por serem muito pequenas não ostentavam nenhum equipamento urbano.

A manutenção dos trabalhos públicos era um ítem bastante dispendioso para as autoridades cívicas. Em períodos de maior afluxo de riquezas muitas vezes construiu-se muito mais do que era realmente necessário, equipando as cidades com edifícios monumentais, tais como templos, teatros, anfiteatros, estádios, circos, banhos, mercados, ruas colunadas, arcos triunfais, aquedutos e fontes ornamentais. Grande parte desses edifícios exigia manutenção e caso fossem destruídos pelo fogo ou terremoto, por exemplo, eram reconstruídos, normalmente em uma escala mais modesta. Quando passou a época mais pacífica do Principado e a situação ficou mais insegura, fortificações ao redor das cidades tornaram-se essenciais (Jones 1986:736).

O período Helenístico, devido ao péssimo estado de preservação de suas principais cidades, como Alexandria e Antióquia, nos traz poucas informações sobre as suas construções. De fato, os romanos nutriam grande admiração pela cultura helênica, que possivelmente serviu de inspiração para o desenvolvimento da sua arquitetura. Ao contrário da época Helenística, têm-se vasta informação disponível sobre as cidades e os edifícios romanos. A partir de um certo momento, com o desenvolvimento de uma nova técnica construtiva, que usava concreto, a arquitetura urbana de Roma passou a seguir uma nova direção, afastando-se dos métodos tradicionais de construção em pedra empregados pela arquitetura grega. Essa técnica, juntamente com o modelo da basílica, foi uma das grandes contribuições romanas à forma arquitetônica. $\mathrm{O}$ uso do concreto tinha um custo elevado fora do território italiano, por isso nas províncias do império a construção dos edifícios foi adaptada aos materiais disponíveis no local, e eventualmente adotou as tradições construtivas, caso existisse alguma. Assim, a arquitetura romana, na vasta área do império, ao invés de ser estandartizada, apresentava uma 
variedade de sistemas de construção e tradições (Tomlinson 1992:19). Veremos detalhadamente mais à frente que, no caso do nosso objeto de estudo, as igrejas protocristãs, surgidas dentro dos limites do Império Romano, que elas constituem um modelo arquitetônico que foge ao padrão que Tomlinson nos apresenta, uma vez que na maioria dos casos sua forma segue uma tradição, que é o uso da planta da basílica civil romana em um novo contexto, o da religião. Também seu sistema construtivo não revela grande variedade nem inovações, usando a construção em pedra e a ordem coríntia, reminiscência do período grego helenístico, em grande parte de suas obras.

De qualquer maneira o desenvolvimento do concreto e de técnicas relacionadas a ele tiveram grande influência na forma das cidades romanas. Esse material permitiu a execução de abóbadas sólidas no teto, o que proporcionou a cobertura dos espaços com maior facilidade e de forma mais durável, levando a uma maior ênfase, em termos arquitetônicos, no interior dos edifícios. Isso provocou uma mudança nos hábitos sociais (Tomlinson 1992:28). Por exemplo, os banhos, que na sociedade grega eram parte de uma estrutura de salas funcionais cobertas ligadas aos ginásios, que não tinham cobertura, no mundo romano transformaram-se em locais de reunião, mais do que estruturas para higiene, materializados nos imensos estabelecimentos para banhos imperiais, com amplas salas principais e inteiramente cobertos com abóbadas de concreto, construídos por ordem de vários imperadores para o povo.

A água era trazida até as cidades através de aquedutos, que freqüentemente venciam uma distância considerável até a nascente, e era encanada até as fontes públicas e os banhos. Sob o pagamento de uma taxa, a água também poderia ser fornecida às casas privadas (Jones 1986:735).

Os banhos públicos eram considerados um equipamento essencial da vida civilizada, e toda cidade respeitável mantinha pelo menos um deles; Antióquia, por exemplo, tinha dezoito, um para cada bairro da cidade. "A manutenção dessas grandes estruturas devia ser cara, e seus servidores tinham de ser pagos, mas o encargo mais pesado era o combustível, que era consumido em enormes quantidades" (Jones 1986:735-736). O combustível nesse caso era a madeira, usada como lenha para o aquecimento da água nos banhos romanos.

Um traço comum, presente nas cidades desde Micenas da Idade do Bronze até a Constantinopla cristã, é a sua dependência em relação aos deuses. A relação que se estabelecia entre deuses e cidadãos foi, em alguns aspectos, similar àquela entre o servo e o seu senhor. Independentemente de suas crenças, que mudaram no transcorrer do tempo, nenhuma cidade poderia existir sem os deuses. Dessa forma sua contribuição para a cidade é contínua. Foi a partir do século VII a.C. que se desenvolveu na Grécia a idéia de proporcionar aos deuses edifícios suntuosos e, assim, o templo foi o primeiro edifício monumental a surgir no espaço grego, ainda no período arcaico. Estabelecida essa idéia, templos e edifícios relacionados foram erigidos. Desde a época da cidade grega clássica, a tendência geral é se ter ao menos um grande templo no centro da cidade ou próximo dele, e essa tradição foi também adotada para as igrejas das cidades cristãs (Tomlinson 1992:17-18).

Com a substituição do culto pagão pelo cristianismo como religião oficial do Estado, os templos se tornaram supérfluos e declinaram. Alguns foram preservados como monumentos públicos, outros substituídos por igrejas inteiramente novas, mais do que simplesmente converter o edifício antigo ao novo uso. Mas nas colônias gregas no Ocidente, na Magna Grécia e Sicília, encontramos templos que foram reaproveitados para um novo uso: igrejas cristãs. São exemplos dessa situação, que são explorados mais à frente, o Templo da Concórdia em Agrigento e o Athenaion de Siracusa. Mas a maioria foi demolida ou se deteriorou, e seu material de construção foi pilhado para utilização em novas obras. Dessa forma, as igrejas puderam substituir os templos sem que a estrutura da cidade fosse alterada (Spieser 1986:49).

Durante o Império Romano foi desenvolvido um novo tipo de edifício, a basílica, uma sala coberta de forma retangular, grande e larga, com colunadas que formavam corredores 
(naves) em seu interior. A sua forma aparentemente não tem nenhuma relação que a identifique com alguma construção do mundo grego, e as suas origens são obscuras: apesar do seu nome sugerir uma origem greco-oriental, não se encontra no Mediterrâneo oriental nenhum precursor claro da sua forma. Alguns autores, tais como Robertson (1997:209) sugerem que a basílica romana tem como precedente o chamado "salão hipóstilo" em Delos, cuja data presumível de existência é 210 a.C. Trata-se de uma sala larga com colunas internas e uma colunada na sua fachada. Porém, para autores como Carter (1995:41), esses dois edifícios não se equiparam. Esse autor sugere como melhor interpretação assumir que os italianos foram de fato capazes de inventar uma forma arquitetônica como resposta às demandas do seu clima e de sua vida social, legal e de negócios. O traçado em planta do "salão hipóstilo" de Delos não apresenta configuração parecida com as plantas das basílicas romanas que tivemos acesso, e como essa relação nos pareceu um pouco forçada, julgamos que a interpretação de Carter é mais adequada. Além disso, concordamos com Carter por entendermos que as mudanças na arquitetura ocorrem em função de novas situações vividas por um grupo. Também já exploramos nesse capítulo o fato de que os romanos desenvolveram novas técnicas construtivas que os gregos desconheciam, e isso deu a eles a possibilidade de construir edifícios mais adequados ao seu modo de vida e às suas necessidades específicas. Vemos que a basílica se tornou, junto com os banhos públicos, um importante meio para mostrar a originalidade romana e seu desenvolvimento na área da arquitetura.

Robertson define a basílica romana como "um salão coberto, via de regra retangular ou absidal, e freqüentemente provido de colunatas internas, destinado a finalidades bastante próximas àquelas do fórum (ao qual normalmente é contíguo), a saber, o intercurso geral, social e comercial, bem como a audição de processos jurídicos; para esta última finalidade existe, usualmente, uma estrutura especial, a tribuna, colocada em uma das extremidades, a ser ocupada pelo magistrado dirigente. Comparada ao fórum, tem a desvantagem de ser me- nos espaçosa e a vantagem de estar protegida do vento e da chuva." (Robertson 1997:316).

Vemos que para os romanos, a basílica era um edifício cívico quase sempre ligado ao fórum. Era de uso múltiplo, abrigando normalmente dependências administrativas e tribunais, mas que também podia servir como local de comércio (Anderson 1997). O fato de ter um impressionante espaço interior fez com que a basílica fosse usada como ambiente de atividades e rituais, tais como julgamentos e a veneração da família imperial (Carter 1995:41). A basílica foi uma forma que se espalhou rapidamente e, juntamente com o senado, constituíam os dois edifícios essenciais para o funcionamento do governo, da legislação e da administração nas cidades romanas.

Em seu tratado sobre a arquitetura clássica, intitulado "Da Arquitetura" Vitrúvio destaca a relação da basílica como um edifício estabelecido anexo ao fórum, e as vantagens de ser um lugar protegido, onde os negociantes podiam se reunir "livres dos rigores das intempéries" (Vitrúvio 1999:121). Entre outras recomendações, esse autor estabelece que a largura da basílica deve ser dimensionada entre $1 / 3$ e metade do comprimento do edifício.

Segundo Mortimer Wheeler, "as basílicas ou salas colunadas não eram desconhecidas para os gregos, mas seu estabelecimento como um anexo da praça pública - o fórum - foi uma inovação romana" (Wheeler 1995:112). O fórum romano era configurado normalmente como um espaço simétrico quadrangular ou retangular, rodeado de pórticos em três de seus lados e com uma basílica ou um edifício municipal no quarto lado. $\mathrm{O}$ acesso à basílica se dava a partir do fórum, por uma colunada num de seus lados maiores. "A basílica normalmente tinha uma fileira de dependências administrativas ao fundo, um tribunal em cada um dos lados menores, por vezes construído em forma de abside, se abria diretamente para o fórum a partir do lado maior que o confinava" (Wheeler 1995:112-115). As representações em planta das basílicas Aemilia e Julia (figs. 2 e 3), apesar de não apresentarem a forma de abside, podem ilustrar o tipo de configuração que nos é apresentado por Wheeler. 


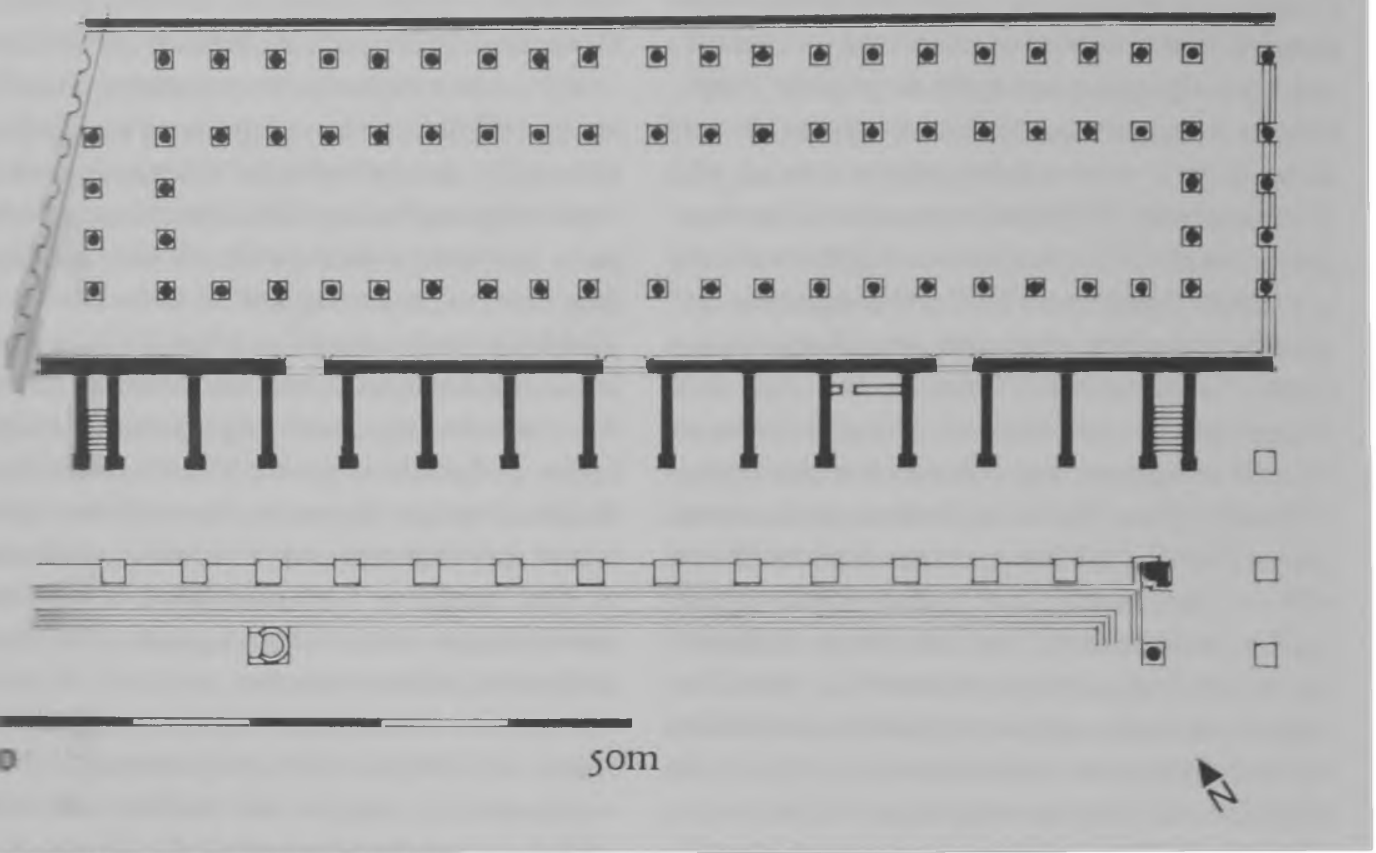

Fig. 2 - Plantá da Basílica Aemilia, em Roma, reconstruída depois de 14 a.C.

Fonte: WARD-PERKINS, J. B. Roman Imperial Architecture, p. 35.

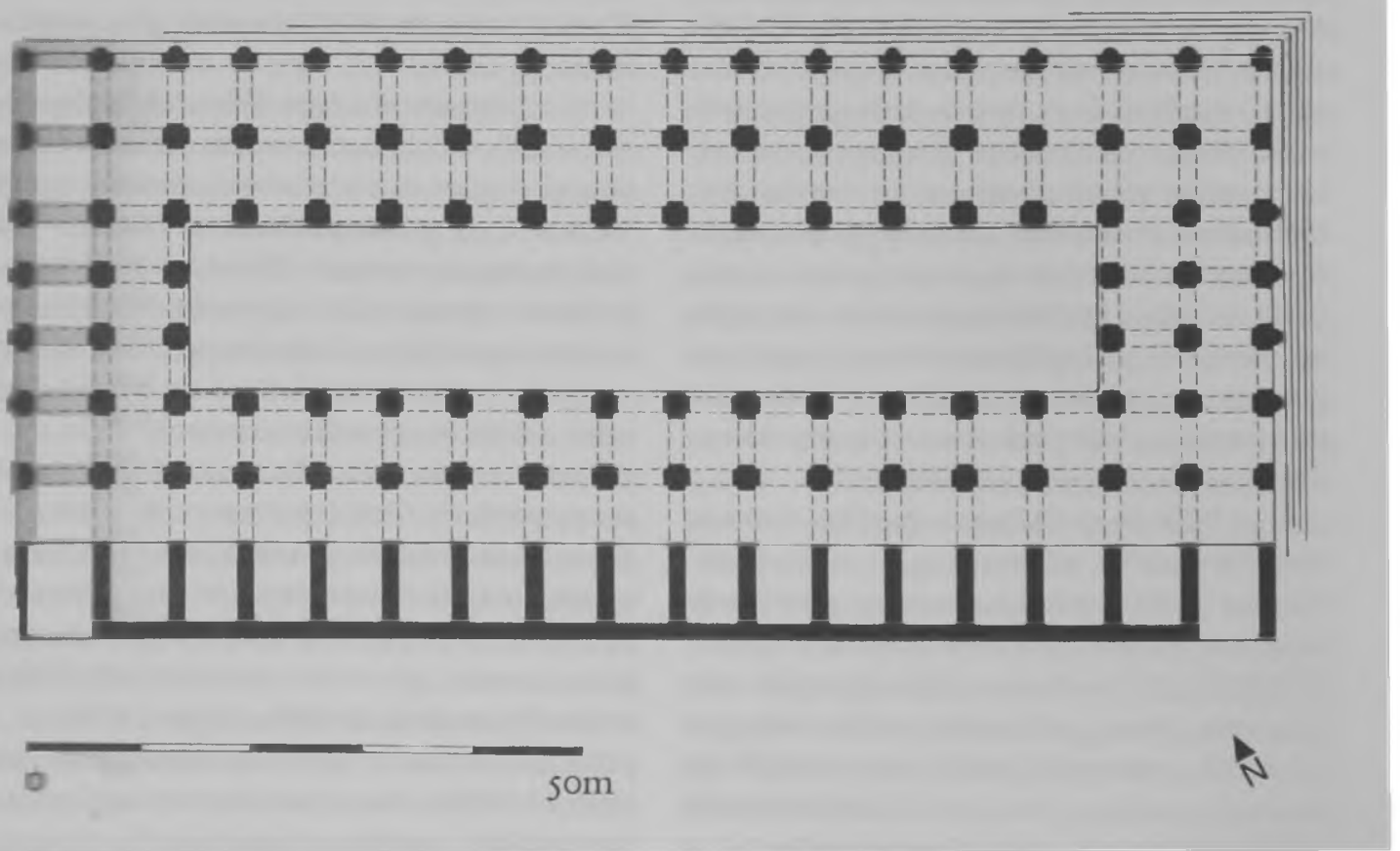

Fig. 3 - Planta da Basílica Julia, em Roma, reconstruída entre 12 a.C. e 12 d.C.

Fonte: WARD-PERKINS, J. B. Roman Imperial Architecture, p. 35. 
A mais antiga basílica que se tem notícia é a Basílica Pórcia, construída em Roma por Catão, o velho, no ano 184 a.C. Antes do final do século II a.C. já haviam mais 3 basílicas na cidade, que, construídas pelas famílias aristocráticas no fórum romano, estavam entre as estruturas mais freqüentadas da área (Robertson 1997:316; Zanker 2000:36).

Nas províncias ocidentais a tendência dominante durante o império foi adotar um traçado simples e bem delimitado, com o fórum rodeado por três pórticos e uma basílica, cujo comprimento era paralelo a um dos lados do fórum.

Como será explorado a seguir, a basílica foi um dos modelos arquitetônicos adotados como base para as igrejas cristãs após a conversão do Império ao cristianismo. Procuraremos, mais adiante, identificar os sinais da influência das basílicas seculares romanas nas basílicas cristãs.

No século VI d.C., as igrejas eram os edifícios que mais refletiam a riqueza urbana do período romano tardio, tanto na sua construção quanto na sua decoração interna. Além das igrejas, os cristãos-romanos também mostravam sua riqueza e seu status na construção de monastérios, hospitais, orfanatos e asilos. Whittow reforça esse aspecto lembrando que "comparados com seus ancestrais dos séculos I e II d.C., os cidadãos do século VI d.C. tinham mudado, ou ao menos estavam mudando, sua atitude em relação ao espaço público e o planejamento urbano. (...) Antes do século VII d.C., as cidades do Oriente Próximo viram seu traçado regular de ruas ser gradativamente transformado em uma rede de vielas estreitas, o espaço aberto da ágora ou fórum substituído pelo souk coberto, e as cerimônias públicas ao ar livre darem lugar a performances no espaço fechado da igreja e logo depois da mesquita. Em outras palavras, a cultura visual da cidade helenística antiga, a pólis, estava sendo trocada por algo diferente." (Whittow 1990:19). Dentro dessa nova ordem, a existência de um templo, um ginásio, ou um banho abandonados era perfeitamente compatível com o orgulho e a opulência da cidade bemconservada.

A arquitetura de Roma não se restringe apenas à arquitetura ali produzida e na Itália, mas é um estilo que foi difundido tanto no
Oriente quanto no Ocidente como um produto do estabelecimento do Império Romano. As classes dominantes adotaram nessas regiões os padrões romanos de comportamento social e organização política, e com eles a necessidade de uma estrutura física para expressar a identidade urbana e tornar possível uma versão do estilo de vida greco-romano (Carter 1995:58-59). Para os cidadãos de fora de Roma era importante se parecer com Roma, porém, mais do que um modelo arquitetônico específico, eles construíam em suas cidades certos tipos de edifícios. $\mathrm{O}$ caso da basílica é um exemplo dessa situação, que a partir do século II a.C. se tornou um dos traços mais característicos de Roma em várias cidades do Império, principalmente em sua porção Ocidental. Um exemplo é a cidade de Cosa, que construiu sua basílica apenas uma geração após as primeiras que foram construídas em Roma, reestruturando assim o seu fórum, como outras cidades da Itália fariam posteriormente (Zanker 2000:36). Para autores como Carter (1995:59), o complexo de construções constituído por templo-fórum-basílica se configura no ingrediente básico de diversos centros de cidades itálicas, e sua ocorrência é, de maneira geral, uma indicação concreta do processo de romanização. Este não deve ser entendido apenas como uma assimilação da aparência externa da cidade pela adoção de estruturas políticas específicas ou de formas arquitetônicas em particular, mas como algo mais abstrato e idealizado, isto é, a noção de como um romano imaginava a cidade ideal, ou certos elementos dela (Zanker 2000:26).

Pode-se notar que a arquitetura é usada pelo imperador e pelas elites locais nas colônias como propaganda de poder, o que justificou o investimento na construção de edifícios como basílicas, teatros e banhos até mesmo nas colônias mais remotas do Império Romano. A questão do uso da arquitetura pelas elites como manifestação do seu poder será aprofundada mais à frente, no capítulo 4 deste trabalho. Apesar de concentrar seu apoio à construção de edifícios monumentais basicamente na capital, o imperador por vezes doava um ou vários edifícios, a fim de conquistar o prestígio local. O uso da arquitetura como meio de propaganda remonta à Grécia do período clássico, onde os templos e 
Formas Arquitetônicas Clássicas em Edifícios Religiosos do Período Bizantino. Revista do Museu de Arqueologia e Etnologia, São Paulo, Suplemento 5, 2008.

os grandes santuários internacionais, como Delfos, Delos e Olímpia tornaram-se lugares onde as cidades-Estado demonstravam suas riquezas e seu prestígio. O tamanho da cidade também foi uma forma de demonstrar poder e prestígio, e esse aspecto foi encorajado pelos governantes do Império Romano principalmente em suas capitais: Roma e Constantinopla (figs. 4 e 5).

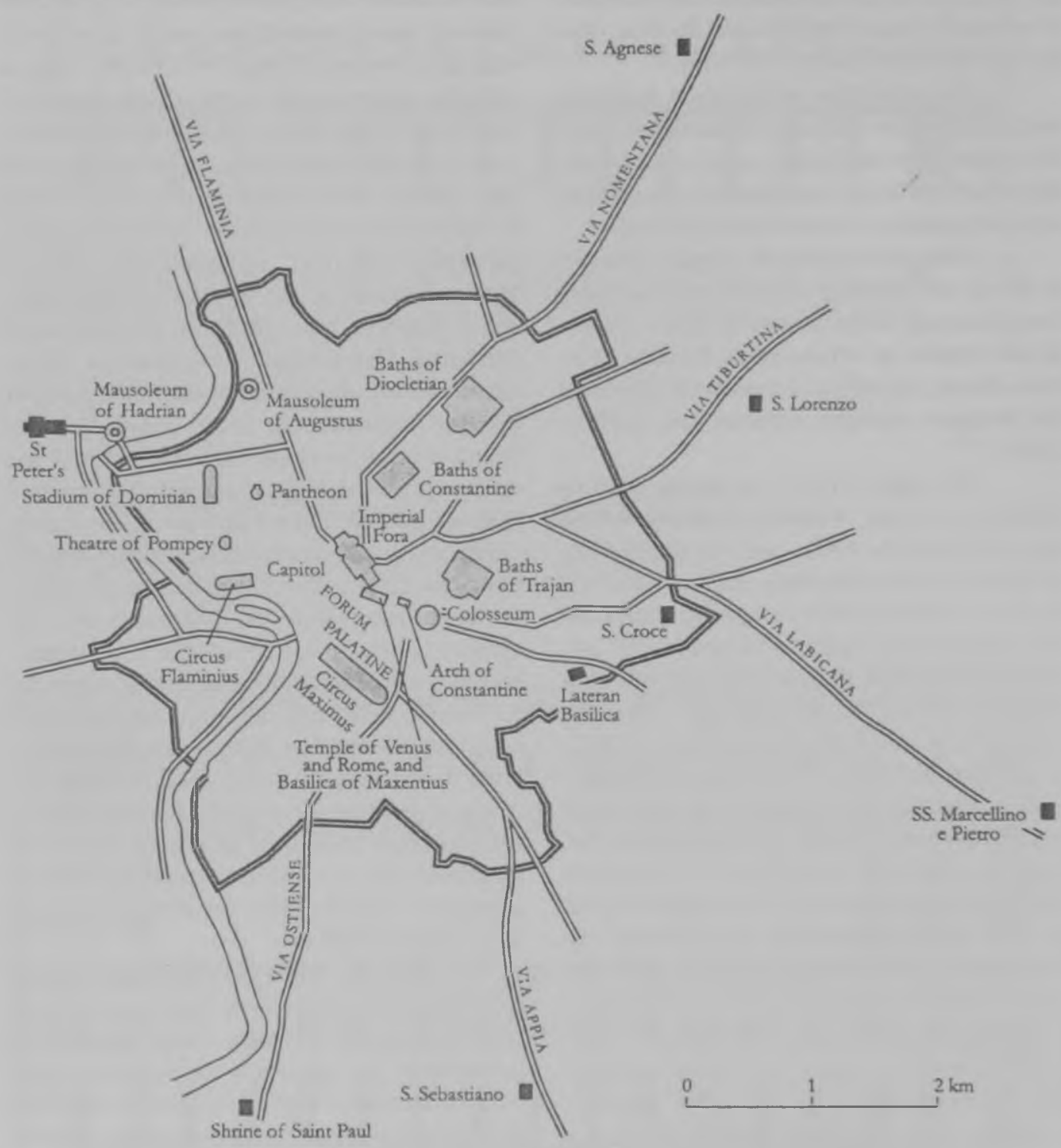

Fig. 4 - Roma na época da morte de Constantino, 337 d.C.

Fonte: CAMERON, A. e GARNSEY, P. (ed.) The Cambridge Ancient History - volume XIII: The Late Empire, A. D. 337-345, p. 397. 
Vemos as cidades como centros econômicos, políticos e sociais onde as elites dominantes moravam, fazendo parte de uma rede hierárquica que as conectava com o mundo mais amplo das províncias e do governo imperial. As cidades também eram o cenário de exposição cultural do poder da comunidade. Porém, entre os séculos V e VII d.C., mudanças culturais tinham ocorrido ou estavam em progresso, e tais transformações se expressaram claramente nos espaços e nos edifícios urbanos. A cristandade e a igreja estavam crescendo como força cultural dominante, e os romanos do Império tardio não queriam mais construir e decorar suas cidades seguindo o modelo clássico. Apesar dessas mudanças, a cidade continuou a cumprir seu papel, assim como as elites que nela viviam.

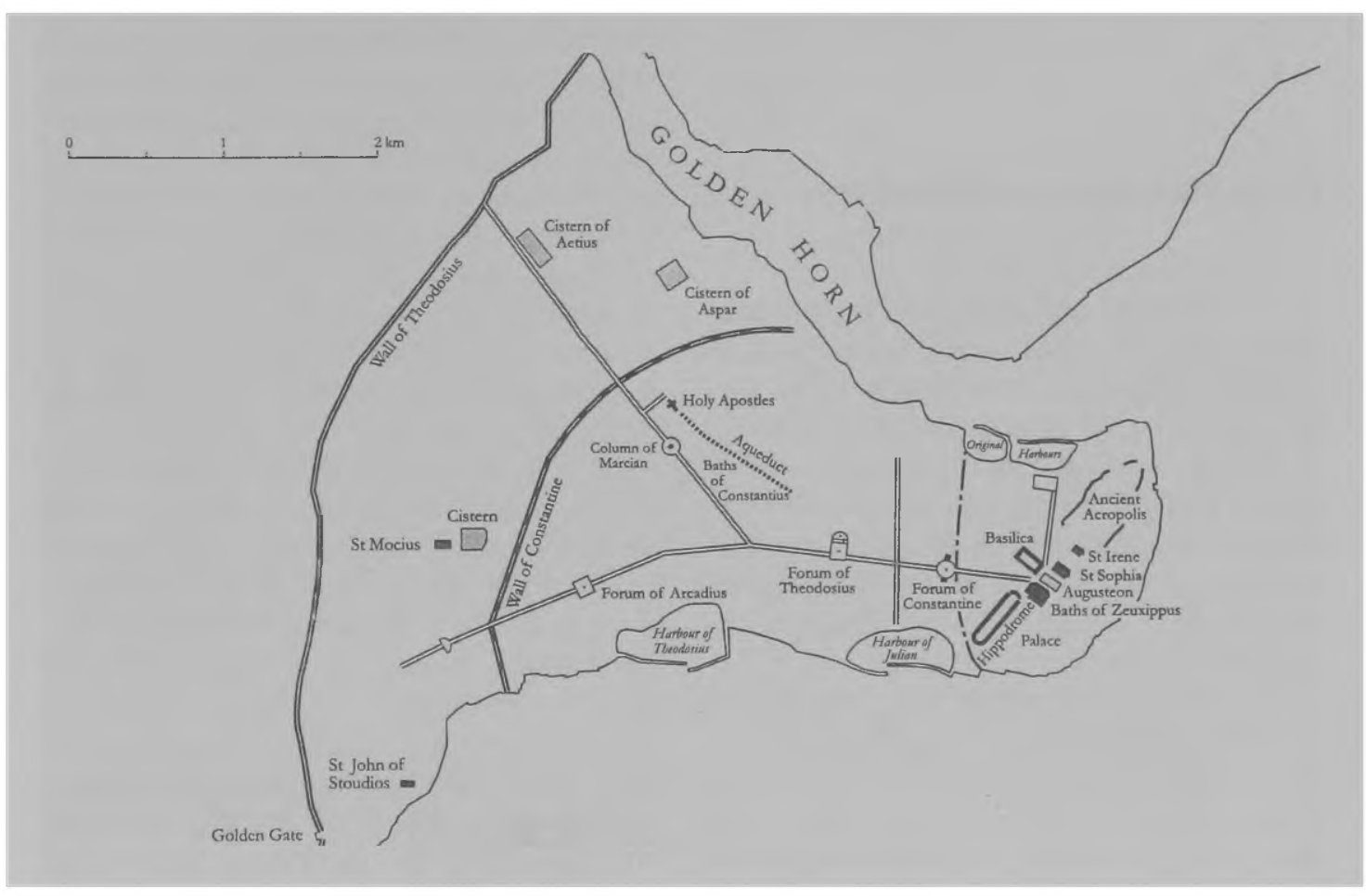

Fig. 5 - Constantinopla no final do século $V$ d.C.

Fonte: CAMERON, A. e GARNSEY, P. (ed.) The Cambridge Ancient History - volume XIII: The Late Empire, A. D. 337-345, p. 387.

Whittow (1990:29), em seu artigo sobre a cidade nos períodos romano e bizantino, afirma que houve uma continuidade no papel das elites urbanas apesar da mudança cultural, e a relação da igreja com os proprietários de terra laicos é um bom exemplo disso. $\mathrm{O}$ que essas elites gastavam na construção de banhos, templos e ginásios a fim de confirmar seu status social, no século VI d.C. passou a ser investido em igrejas e monastérios. Esse processo é, com efeito, a confirmação dos padrões tradicionais, agora sob uma nova aparência, a cristã. Dentro desse contexto, o desaparecimento dos curiales, ao invés de ser um sinal de decadência das cidades romanas, na realidade foi parte de um processo no qual as elites proprietárias de terras se adaptaram a um momento de mudança. Mais do que se apegar à cultura clássica do conselho, essas elites abraçaram o novo mundo cristão. Nesse período, muita coisa mudou, mas grande parte delas permaneceu da mesma forma. Spieser (1986:52), ao procurar compreender a mudan- 
ça do cristianismo chega ao mesmo ponto de Whittow, pois entende essa nova religião como parte de uma estratégia ligada às mudanças na organização do poder e dos fluxos econômicos. É importante notar que a construção de igrejas não foi uma simples questão de fé ou de mentalidade, mas eram interesses importantes que estavam em jogo e por isso sua realização deve ser considerada um investimento.

\section{O surgimento do cristianismo}

O cristianismo nasceu no período helenístico, em meio à civilização greco-romana. Os primeiros pregadores do evangelho foram contemporâneos de Virgílio, de Ovídio, de Horácio, de Sêneca, dos dois Plínios, de Suetônio e de Tácito. Porém, o cristianismo não nasceu sob o olhar dos historiadores e filósofos de Roma, mas suas origens estão no Oriente. Ele nasceu em Jerusalém, na cidade que Plínio, o Velho considerou como a mais célebre do Oriente.

No que diz respeito à religião, o mundo Mediterrâneo alternou-se entre o paganismo, o cristianismo e o islamismo. Os autores Horden e Purcell partilham da idéia de uma relação intrínseca entre a religião e os locais de culto, associada à cultura e à política. Em uma escala ampla, o mar foi o meio da diferenciação religiosa, e também o veículo da mudança. Assim, o Mediterrâneo foi tanto uma zona de fácil transmissão lateral de idéias e práticas como também uma barreira que promoveu divisões entre sistemas culturais. A religião, entre outros aspectos, expressa a relação entre a paisagem do Mediterrâneo e seus habitantes (Horden e Purcell 2000: 406).

Por meio da religião, são expressas as conexões entre regiões, as fidelidades regionais e a sua posição dentro de hieraquias. Em um mundo dividido em milhares de microregiões, como é o Mediterrâneo, esse tipo de observação a respeito da religião torna-se bastante importante. $\mathrm{O}$ fenômeno da peregrinação, presenciado por todas as religiões que se desenvolveram ali, também é um acontecimento importante que marca as relações entre as regiões. Compreender alguns aspectos da relação entre religião e espaço é essencial para o entendimento da maneira pela qual as unidades culturais se desenvolveram na história do Mediterrâneo (Horden e Purcell 2000:407; 445-446).

Pelo Mediterrâneo, o cristianismo se espalhou do Oriente para o Ocidente, indo de uma extremidade ao coração do Império Romano, que lhe serviu como molde nesse processo de expansão (fig. 6). As características desse processo, de um lento, porém enorme crescimento de uma comunidade de seguidores do cristianismo, aparenta ter em seu centro uma mudança da mentalidade. Contudo, isso não foi sempre tão simples, e está inserido num longo processo de maturação eclesiástica (MacMullen 1984:3). Assim, o processo de conversão tomou lugar na mente das pessoas nas bases do que eles sabiam, ou pensavam saber.

Autores da época, tais como Flávio Josefo, relatam que, na época do surgimento do cristianismo, o século I d.C., na região da Judéia (Palestina) existiam vários movimentos religiosos que propunham uma renovação das doutrinas vigentes no judaismo. Um deles era o dos essênios, os "voluntários da Nova Aliança" sediado em Qumram, mas havia outros, como os fariseus e a seita de João Batista. Enquanto os essênios eram um grupo organizado e guiado por sacerdotes da linhagem do templo de Davi, o grupo de Jesus, ao menos em seu início, era governado de maneira mais informal e carismática, e era constituído principalmente por laicos e mulheres (Meeks 1992:286-287).

Para Meeks (1992:289-290), que escreveu o capítulo a respeito do cristianismo na obra Storia di Roma, o cristianismo só se expandiu de maneira espantosa porque não permaneceu como um movimento rural, circunscrito às vilas e campos da Judéia e da Galiléia. No máximo dez anos após a morte de Jesus seus seguidores investem na forma urbana, proselitística do cristianismo, e era essa a forma do futuro. Segundo hipóteses, existiram dois centros de atividade dos seguidores de Jesus. Um deles se estabeleceu nas vilas da Judéia, Galiléia e Samaria e o outro em Jerusalém. 


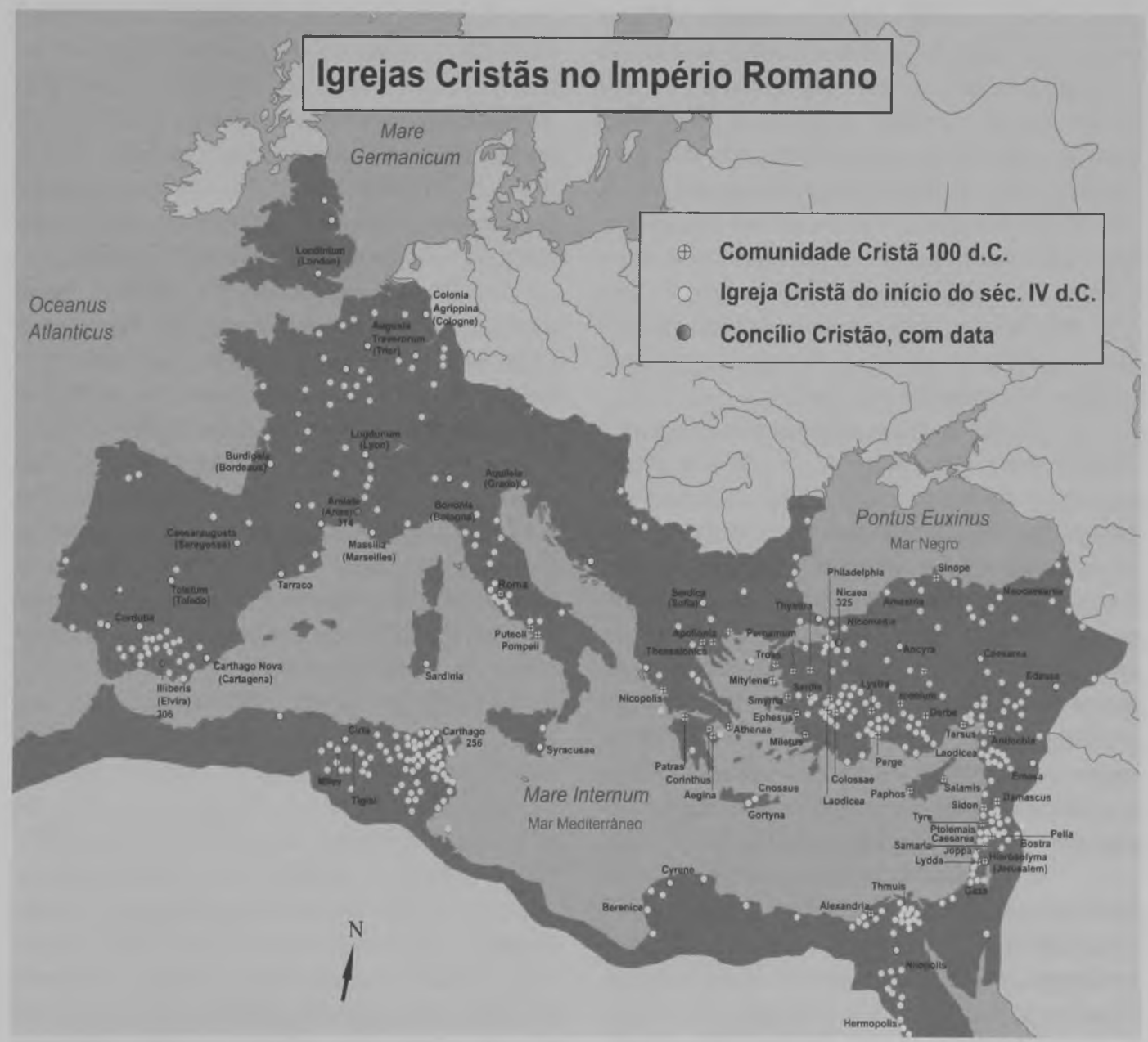

Fig. 6 - Igrejas cristãs no Império Romano. 
A partir de certo momento, provavelmente uma década após a morte de Jesus, o modelo de expansão do cristianismo foi baseado na missão urbana. Nessa época, a introdução do cristianismo é atestada em várias cidades: Antióquia, Damasco, Roma e provavelmente Alexandria. A chave da estratégia cristã na área urbana era o núcleo privado. A comunidade cristã do século I d.C. divergia muito do mundo romano no que se refere à questão do culto. Apesar de os cristãos seguirem ritos específicos, eles não tinham santuário, templo, estátua de culto, nem sacrifício; não organizavam festas públicas, nem manifestações musicais e nem peregrinações. A submissão a um só Deus e a um só Senhor excluía a sua participação em qualquer outro culto (Meeks 1992:292-294). As crenças para as pessoas que viviam nesse período da Antigüidade Tardia baseavam-se em ações que, aliadas às crenças, tornavam-se realidade.

O cristianismo apresentou idéias que demandavam uma escolha, e não tolerância, enquanto algumas dessas idéias estavam nos limites do aceitável, outras eram mais difíceis de se compreender (MacMullen 1984:17). Por exemplo, o combate aos demônios serviu como um dos propósitos essenciais para a definição cristã de monoteísmo: tornou visível fisicamente (ou dramaticamente) a superioridade da força do Deus cristão sobre todos os outros. Um e somente um era Deus. O restante eram demônios e, portanto, possuíam poderes menores, que de qualquer maneira ninguém gostaria de venerar.

É importante ter em mente as conseqüências desse cenário. Quando eram persuadidos, eles produziam uma lealdade especial. Histórias e milagres realizados por outros deuses também circulavam, fazendo um grande número de convertidos; mas esses novos devotos não se desligavam totalmente do paganismo. Eles somente concentravam uma gratidão e convicção em mais um deus. Cristãos convertidos, no entanto, negavam o nome e até mesmo a existência de todos os outros deuses, a partir do momento de sua conversão (MacMullen 1984:28).

A igreja cristã antes de Constantino aparentemente manteve-se contida dentro de si mesma, nos seus serviços religiosos (privados), ou em suas políticas matrimoniais, onde católicos procuravam se casar com indivíduos da mesma religião. Seus ensinamentos eram oferecidos usualmente para os iletrados, por indivíduos provenientes das camadas inferiores da sociedade, como também foram apresentados em textos destinados aos leitores das classes mais altas. Esses preferiam manter distância entre eles e o cristãos das classes inferiores (MacMullen 1984:35-37).

No decorrer do século IV d.C. o número de cristãos, tanto em Roma quanto por todo o império, cresceu continuamente. Alguns setores da sociedade que adotaram a nova religião são mais visíveis que outros, como, por exemplo, as mulheres da ordem senatorial. Mas de maneira geral é impossível estimar o número de cristãos que existiam nessa época (Beard 1998:375-376).

Durante os séculos II e III d.C., havia uma série de opções de crenças abertas à população em Roma, encabeçadas pelos cultos do Estado. A partir de Constantino a escolha foi simplificada - ou revertida. Em parte devido à patronagem imperial, o cristianismo em expansão tornou-se a linha de base, enquanto os cultos tradicionais tornaram-se a partir desse momento a opção, uma questão de escolha. Alguns cristãos por sua vez tentaram incorporar elementos da tradição romana. Dessa maneira, a maior mudança ocorrida no século IV d.C. não é tanto a derrota do paganismo pelo cristianismo, mas a sua mudança de status. Tendo o cristianismo sido adotado como a religião oficial do império, os cultos tradicionais de Roma passaram a ser uma religião eletiva, uma questão de escolha, isto é, para "ser romano" não era mais necessário adotar os seus cultos tradicionais; a opção religiosa não estava mais relacionada à identidade romana. A adesão da população em Roma à igreja cristã causou problemas de identidade e status. "A celebração dos antigos festivais em Roma, ao que parece, manteve-se como um evento popular até o século IV d.C., e os jogos associados à essas celebrações (razão pela qual compreendemos a preservação dos templos romanos por parte de Constâncio) continuavam atraindo multidões. Talvez toda essa massa fosse pagã; mas existem poucas razões para se pensar assim - apesar de tudo, o escritor cristão Ausônio podia escrever um afetuoso poema a respeito dos festivais romanos. (...) Para vários senadores, acreditamos que essa questão deve ter sido 
muito importante. Os senadores cristãos, em geral, eram solicitados por seus colegas pagãos a manter o prestígio de Roma em um mundo em transição. E a identidade tradicional de Roma (ao menos para a elite) era derivada dos cultos tradicionais." Até a metade do século III d.C. alguns senadores tinham se tornado cristãos, mas deixaram sua cristandade restrita à esfera pessoal. Os limites entre paganismo e cristandade parecem ser, a partir dessa breve exposição, mais fluidos do que uma simples dicotomia possa sugerir (Beard 1998:365;375-378; 388).

Millar (1993:21) considera o desenvolvimento que o cristianismo conseguiu alcançar entre o reinado de Augusto até a morte de Constantino como um dos eventos mais importantes desse período. Até esse momento uma literatura cristã em língua semítica, o Sírio, existiu por pelo menos um século. Um tipo arquitetônico anterior às igrejas, chamado domus ecclesia - um edifício residencial adaptado para servir aos cultos religiosos, e posteriormente igrejas propriamente ditas, foi construído em diversos lugares, da Mesopotâmia até Antióquia, Tiro, Jerusalém ou sul da Síria. A peregrinação até os locais bíblicos e às novas e magníficas igrejas da Terra Santa já tinham sido bem estabelecidas.

\section{O Império Romano no período bizantino - Constantino e o cristianismo}

Quando Constantino subiu ao poder, no ano 324 d.C., teve início uma fase de grandes mudanças culturais na historia do Império Romano, e também da região da Palestina. Mas para entender as condições em que o seu governo se estabeleceu, é necessário rever sua trajetória até esse momento, recuando um pouco mais no tempo até o reinado de Diocleciano, onde, a nosso ver, foi criado o quadro de situações que foi posteriormente marcado pela presença de Constantino.

Após meio século de crise no Império Romano, em 284 d.C., Diocleciano, comandante da cavalaria no exército romano, atinge o posto de imperador. No ano de 293 d.C. ele adota um sistema de governo que ficou conhecido como tetrarquia, a primeira tetrarquia, para fazer a distinção com a segunda tetrarquia, que existiu por um curto período de tempo após seu afastamento do poder, ocorrido em 305 d.C. Ficou estabelecido com esse sistema que o Império Romano seria governado por 4 indivíduos: dois imperadores (Augustos) e dois Césares, que eram imperadores com menor importância. A porção ocidental do Império Romano ficou sob a responsabilidade de Maximiliano como Augusto e Constâncio, pai de Constantino, como César e na parte oriental o Augusto era Diocleciano e o César, Galério. Esse sistema não dividiu o império. Diocleciano ainda permanecia como autoridade central. Esse novo sistema proporcionou uma maior eficiência na administração do império e maior segurança nas fronteiras (Pohlsander 2004:4-9), o que garantiu a sua estabilidade no período de 20 anos em que Diocleciano governou.

Diocleciano providenciou ainda uma nova organização territorial para o império. Haviam quatro áreas de responsabilidade: o Ocidente, a Itália, o Ilírico e o Oriente. Cada uma dessas áreas tinha a sua própria capital, mais especificamente, residências imperiais: Constâncio morava em Trier, Maximiliano em Milão, Galério em Tessalônica e Diocleciano em Nicomedia. A cidade de Roma, apesar de permanecer como assento do senado, tinha a partir desse momento sua importância bastante diminuída (Pohlsander 2004:9).

No ano 305 d.C., Diocleciano e Maximiliano retiram-se do poder e para substituí-los, Galério e Constâncio ascendem ao posto de Augusto. Logo depois, no ano 306 d.C., Constâncio morre e os soldados proclamam Constantino, seu filho, como Augusto. Em Roma, o senado e a Guarda Pretoriana, que durante muito tempo estavam sofrendo com a diminuição do seu poder, prestígio e privilégios nomeiam Maxêncio, o filho de Maximiliano, como imperador. Alguns anos depois, em 312 d.C., Maxêncio e Constantino se enfrentaram na batalha da ponte Mílvia, na qual esse último sai vitorioso, passando a ser o único governante da parte ocidental do Império Romano. Na porção oriental desse império, no ano de 313 d.C. Licínio, que substituiu Ga- 
lério no poder, vence Maxímio Daia, o César escolhido por Diocleciano, tornando-se o governante dessa região (Pohlsander 2004:16-21;25). Nesse mesmo ano Constantino e Licínio, os dois imperadores romanos, se encontram em Milão e lá assinam um documento pelo qual concordam com a tolerância religiosa e na adoção de uma mesma orientação nas questões da religião; esse documento ficou conhecido como Édito de Milão. Com o passar do tempo a tensão entre os dois imperadores aumenta, até que, no ano 316 d.C. ocorre a primeira luta entre eles. Em 324 d.C. acontece a segunda guerra, na qual Licínio é derrotado por Constantino, que passa a ser o único governante do Império Romano (fig. 7).

Convertendo-se ao cristianismo e tornando-se o primeiro imperador cristão, Constantino adotou essa crença como religião oficial do Império. Esse foi o ápice do processo pelo qual a cristandade se estabeleceu no mundo romano, e foi a partir daí que a região da Palestina passou a ser valorizada como centro de culto, trazendo grandes conseqüências, como uma mudança radical da situação vigente. Essa época, conhecida como Período Bizantino, foi um momento em que a cristandade estendeu-se em um ritmo acelerado (Levy 1995:470; Tsafrir 1993:1).

A conversão de Constantino aconteceu no ano de 312 d.C., durante a batalha da ponte Mílvia, contra Maxêncio. Sua conversão foi um dos acontecimentos mais inesperados da história de Roma. Mais adiante nessa dissertação discutiremos em maior profundidade as questões que a historiografia levanta a respeito de Constantino, pois muitos historiadores, como Burckhardt (1983) e Pohlsander (2004), entendem essa conversão não como uma devoção sincera ao cristianismo, mas como uma sensibilidade para entender a situação que ele vivia e se aproveitar da religião para atingir propósitos pessoais. A partir desse momento, Constantino pediu a tolerância de culto aos cristãos, incentivou a construção de igrejas e passou a fazer doações às autoridades cristãs. Com o Édito de Milão, publicado no ano 313 d.C, Constantino transforma a Cristandade de uma religião perseguida para uma religião permitida, dotando-a de proteção imperial. Além disso, Constantino também foi pessoalmente responsável pela fundação de novos edifícios de igrejas (Beard 1998:366-368).

No ano 325 d.C, Constantino foi responsável por mudar o concílio de bispos que seria realizado em Ancyra (cidade moderna de Ankara) para Nicéia (cidade moderna de Iznik, no noroeste da Turquia), uma cidade mais acessível para os bispos do Ocidente e mais conveniente para o próprio imperador. Ele dirigiu o concílio, e fez valer a sua vontade de banir a doutrina Ariana da crença cristã. "A fusão da lei religiosa com a autoridade imperial não pode ser exposta de maneira mais dramática" (Beard 1998:370-371). Esse concílio foi de grande importância para a igreja cristã não apenas pelas questões que nele foram debatidas, mas também porque reafirmou a tendência, já delineada no Édito de Milão, de uma ligação íntima entre a nova religião e o poder imperial.

Em um curto espaço de cinco anos, Constantino fez edificar a cidade de Bizâncio, às margens do estreito de Bósforo. Posteriormente a cidade ficou ligada ao seu nome, renomeada para Constantinopla. Essa cidade foi inaugurada no ano 330 d.C. como nova capital do Império Romano, e foi o seu centro político, religioso e econômico até o ano de 1453 d.C., quando a cidade foi tomada pelos turcos. Essa data marca para os estudiosos do Ocidente, como já mencionamos na introdução desse trabalho, o final do Período Bizantino. Seu criador tinha a intenção de fazer de Constantinopla uma seqüência lógica da tradição romana. Ao invés disso, por uma série de circunstâncias, tornou-se o gérmen de uma nova civilização: a civilização bizantina, que demonstrou uma grande capacidade artística e intelectual. Seu período de gestação durou quatro séculos - do século IV ao século VIII d.C., e sua existência abrangeu um período de cerca de um milênio (Barral e Altet 2002;7-9; Diehl 1961:12-14).

Para se avaliar o que era essa civilização, será suficiente considerar algumas das grandes cidades do Império, começando por sua capital. Constantinopla era uma cidade rica e próspera. Construída no ponto de encontro entre a Europa e a Ásia, era um grande mercado onde se encontravam os povos da península dos Balcãs e de além-Danúbio, assim como os do Oriente asiático. 


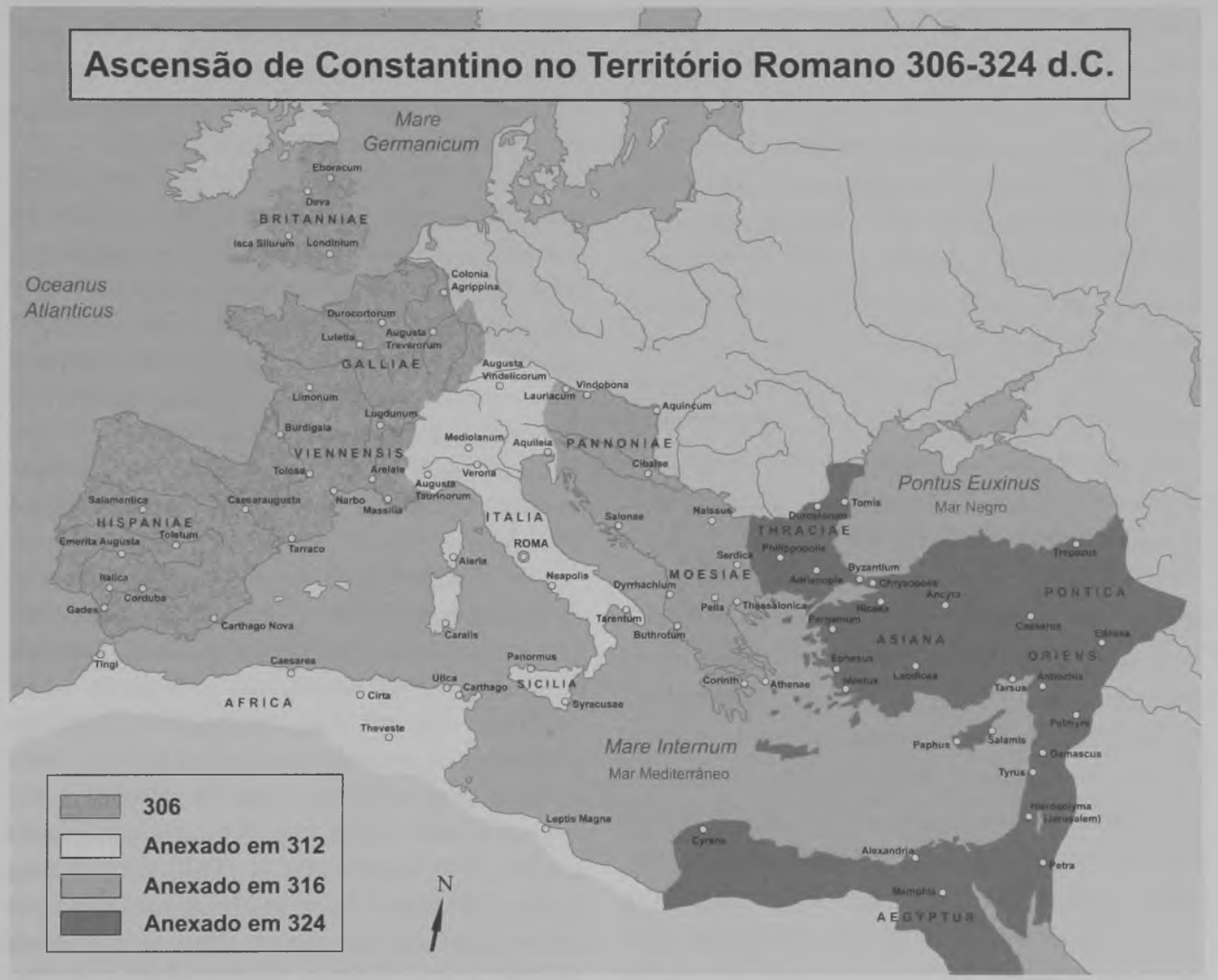

Fig. 7 - Conquistas de Constantino no território romano. 
Por muitas razões, o Império Bizantino atingiu durante a Idade Média um prestígio incomparável. Enquanto a maior parte das grandes cidades da Europa desse mesmo período não passavam de lugares pobres e medíocres, Constantinopla era a única grande cidade cristã da Europa. Para tornar magnífica a nova capital, Constantino mandou construir edifícios imponentes e, em particular, várias igrejas cristãs. Mandou abrir grandes avenidas, que cortavam toda a cidade, e praças rodeadas de palácios suntuosos, destacando-se entre elas o foro de Constantino, em cujo centro erguia-se uma alta coluna de bronze. A cidade estava repleta de mosteiros ilustres, dos quais muitos eram centros de cultura intelectual ou artística. Para enfeitar a capital, adornou-a com obras-primas da arte antiga, despojando os mais ilustres santuários pagãos. Enfim, levou para Constantinopla muitas das instituições de Roma, em particular o Senado. E na linguagem oficial, Constantinopla passou a ser chamada de "nova Roma" (Diehl 1961:55; Levy 1995:473-477).

Nessa nova capital o poder imperial tomou novo aspecto. Há muito tempo se anunciava uma nova concepção de poder soberano, e Constantinopla terminou essa transformação. O imperador passou a ser soberano por direito divino, designado e inspirado por Deus, gozando de absoluta autoridade; foi considerado pessoa sagrada e, do mesmo modo tudo o que dele se aproximava, e o que fazia, recebia o mesmo epíteto. O príncipe foi cercado por um cerimonial magnífico e uma etiqueta complicada, destacando-o do resto da humanidade. A vitória do cristianismo teve como conseqüência outra transformação: o imperador tornou-se imperador cristão, que tinha por tarefa difundir a fé, defendê-la contra todos os inimigos, e, naturalmente, proteger a Igreja. Assim, o cristianismo tornou-se a verdadeira religião do Estado, e a posição que o imperador ocupava no universo cristão fez com que o poder estivesse fortemente concentrado em suas mãos: era ele que detinha todo o poder político e espiritual (Diehl 1961:59; Levy 1995:473-477).

\section{Arte e arquitetura no período bizantino}

Os bizantinos, pelas sucessivas retomadas dos modelos antigos desenvolveram nova manifestação artística, resultando nas obras paleocristãs. Sem jamais se esquecerem da noção de transcendência da arte, eles conferiram à ela um charme que se inspirava no exemplo grego. Quando a arte bizantina atingiu seu apogeu, estabeleceu-se um equilíbrio entre a forma clássica e o conteúdo religioso, entre a beleza antiga e a espiritualidade cristã (Stern 1966:1).

A arte bizantina era uma arte forte, que evoluiu com o correr dos séculos, capaz de inventar e de inovar: essa arte, na arquitetura, criou tipos novos de edifícios sagrados, e nas igrejas coroadas de cúpulas pôs uma decoração magnífica e suntuosa, mosaicos ou afrescos, onde a pintura bizantina, traduzindo os temas da iconografia sagrada, soube criar muitas composições notáveis; essa arte produziu obras refinadas que marcaram a civilização bizantina (Diehl 1961:48).

Quem fala da arquitetura bizantina evoca suas igrejas. Decerto, a arquitetura civil continua a existir neste império que recebeu a herança de Roma. O palácio imperial permanece como centro da vida oficial, a construção de edifícios públicos e de residências privadas não foi interrompida nem na capital nem nas províncias durante o período da formação e consolidação do Estado. No entanto sabe-se muito pouco sobre essas edificações. Seus vestígios não são suficientes para dar uma noção sobre a arquitetura civil bizantina, de forma que são raros os estudos dedicados a esse assunto (Stern 1966:5).

Tanto as fontes textuais quanto a documentação arqueológica revelam que o período bizantino foi uma fase de grande prosperidade econômica na Palestina e de um grande crescimento da população, que alcançou níveis nunca vistos anteriormente. A cultura bizantina reuniu tradição romana, civilização greco-helenística e cristandade (Levy 1995:475). Os dois elementos antigos representavam a continuidade derivada de Roma, do Oeste, e do Leste Helenístico. A cristandade foi a inovação revolucionária e a fundação de um império cristão na Palestina, 
terra onde o Messias cristão havia nascido e morrido, ocorreu antes do que em outras províncias romanas (Tsafrir 1993:1).

No urbanismo e na arquitetura do período bizantino, podem ser observadas duas tendências divergentes: a permanência da tradição romana e a introdução de uma tendência não-clássica (Levy 1995:473). O que se percebe nas cidades bizantinas é que a arquitetura grecoromana prevaleceu, porém com modificações e adaptações demandadas pela mudança de atitude da sociedade e pela nova religião.

A vida nas cidades nesse período em toda extensão do Império Romano era uma mistura das tradições romanas do passado e dos novos conceitos cristãos. $\mathrm{Na}$ região da $\mathrm{Pa}$ lestina, em meio a essa mistura havia também os judeus, que habitavam essa região quando ela foi conquistada pelos romanos, e esforçavam-se para preservar as suas tradições (Levy 1995:473).

A mais importante mudança que ocorreu na paisagem urbana desse período foi o gradual desaparecimento dos templos pagãos, demolidos ou abandonados, e o predomínio de igrejas, cujo número em cada cidade excedia o de templos anteriormente encontrados (Levy 1995:475).

Com o estabelecimento do cristianismo como religião oficial do Império Romano, entre os cristãos verifica-se que a veneração dos ídolos foi substituída pela veneração de ícones, locais sagrados e relíquias, que era algo que não existia nessa religião no início de sua organização. Num altar erigido no ponto focal de cada igreja, o ritual culminava em ato de sacrifício. Vale lembrar que nas culturas grega e romana, o sacrifício era parte essencial do ritual religioso. Porque, na tradição judaica, a parte principal do ritual era constituída pela oração e pela leitura das Escrituras, realizadas nas sinagogas, os edifícios de culto religioso judeu (Levy 1995:477). O ritual cristão agrega características dessas duas culturas, uma vez que dele fazem parte a oração e leitura das escrituras, e também um sacrifício, ainda que simbólico. Ressaltamos aqui e exploramos mais a fundo no capítulo 4 dessa dissertação que, após a atuação de Constantino, o cristianismo nunca mais foi o mesmo.
Constantino e sua mãe Helena foram os primeiros a construírem igrejas na Palestina. Antes disso, os cristãos não tinham uma casa de oração com uma forma arquitetônica diferenciada; seu local de reunião era a $d o$ mus ecclesia - um edifício doméstico adaptado para servir ao propósito da religião (Levy 1995:477). A domus ecclesia foi a célula-base do movimento cristão na cidade, e não abrangia apenas a entidade familiar reunida para a pregação, mas uma pequena comunidade cristã (Meeks 1992:293).

A construção de igrejas foi um dos maiores objetivos da empresa imperial. Quatro igrejas foram construídas por Constantino na Palestina: a Igreja do Santo Sepulcro em Jerusalém, a Igreja da Natividade em Belém, a Igreja do Carvalho de Abrãao em Mamre, e a Igreja Eleona no Monte das Oliveiras. As três primeiras em nos locais de altares pagãos, que foram destruídos (Levy 1995:477-478).

Como Eusébio nos relata no capítulo 25 de Vida de Constantino, esse governante inicia seu trabalho na Palestina ordenando a construção de uma igreja no local onde Cristo ressuscitou - a Igreja do Santo Sepulcro, local onde o imperador Adriano havia erigido um templo de Afrodite (Eusebio de Cesarea 1994:288-294; Tsafrir 1993:23).

Além de Constantino e de sua mãe Helena, a construção de igrejas viveu mais dois períodos de prosperidade. Um deles foi durante o reinado de Teodósio II (408-450), cuja esposa, a imperatriz Eudoxia, construiu igrejas dentro de Jerusalém e em sua periferia no segundo e terceiro quartos do século $\mathrm{V}$ d.C. As igrejas construídas por essa imperatriz eram edifícios pequenos se comparados às grandes basílicas erguidas mais ou menos na mesma época em Roma.

Um terceiro período importante de obras de igrejas foi no reinado do imperador Justiniano I (527-565), durante o qual houve um desenvolvimento sem precedentes na construção desse tipo de edifício na Palestina. Graças à prosperidade e à relativa estabilidade política que marcou o império bizantino durante o longo reinado de Justiniano, vários edifícios foram construídos; não apenas igrejas, mas também edifícios seculares (Stern 1993:305). 
Arquitetonicamente, as igrejas podem ser divididas em quatro tipos distintos, de acordo com sua planta: basílica, capela, igrejas com plantas centrais (tanto circulares quanto octogonais) e igrejas com planta cruciforme. $\mathrm{O}$ três primeiros tipos são derivados, com adaptações, de protótipos romanos: basílica civil romana ou basílica palaciana, arquitetura romana funerária, ou salas de recepção palacianas. Somente o tipo cruciforme é uma inovação bizantina, introduzida primeiramente por Constantino na sua Igreja dos Apóstolos em Constantinopla, onde ele foi enterrado. As basílicas com transepto são variações desse tipo (Levy 1995:478). Os tipos de igrejas serão explorados mais adiante, quando tratarmos do catálogo de igrejas.

Uma característica das igrejas bizantinas, presente em toda a produção arquitetônica dessa civilização, é o abandono das formas exteriores monumentais, dos pórticos e das colunadas, característicos da arquitetura clássica, para concentrar os seus efeitos no interior. $O$ edifício de culto passa a ser o símbolo do universo cristão. Nos salões as imagens têm um local predeterminado, e na organização das figuras prevalece a hierarquia celeste. Um jogo de linhas mais abstrato, a gama de cores mais irreais lhes oferecem meios de expressão que a arte pagã desconhecia (Stern 1966:1). 


\section{3 - Catálogo de igrejas}

$A$ tálogo de igrejas da época bizantina cuja existência foi atestada na região da $\mathrm{Pa}$ lestina. Ele foi organizado por ordem alfabética dos locais onde uma ou mais igrejas protocristãs foram encontradas.

As informações para a elaboração desse catálogo foram encontradas em grande medida em duas obras: The New Encyclopedia of Archaeological Excavations in the Holy Land, editada por Stern e Ancient Churches Revealed, editada por Tsafrir (vide bibliografia). No catálogo abreviamos os títulos dessas obras, indicando apenas as suas iniciais: TNEAEHL e ACR, respectivamente. Foi por essas publicações que tivemos acesso aos estudos e às escavações realizadas nas igrejas da Palestina, que nos forneceram as informações a respeito de cada edifício que faz parte desse catálogo. Nessas publicações nossa seleção foi orientada por critérios arquitetônicos, como forma, mais especificamente a sua configuração em planta, e elementos decorativos, tais como estilo dos capitéis e das colunas.

Com relação à forma arquitetônica nos concentraremos essencialmente na planta dessas igrejas, porque a amostragem que compõe esse catálogo traz exemplos de igrejas que não existem mais, e são representadas, salvo algumas exceções, por reconstituições em plantas feitas com dados levantados em escavações. Somente algumas igrejas tiveram sua reconstituição representada por perspectiva isométrica, fornecendo informação sobre a proporção desses edifícios com relação à sua altura. Sempre que tivemos acesso, privilegiamos a representação tridimensional dessas igrejas em detrimento do seu desenho em planta.

Como havíamos proposto na etapa de projeto preliminar de pesquisa, as igrejas que fazem parte desse catálogo foram escolhidas, dentro do recorte regional e temporal preeestabelecido, por meio de critérios arquitetônicos, porque nos propusemos a desenvolver análises focadas em aspectos relativos à sua forma construída, tais como orientação cardeal, disposição e decoração dos elementos estruturais, relação entre cheios e vazios, disposição e dimensionamento dos espaços e seus usos. Todas essas características são elementos que podem facilmente ser visualizados nas representações em planta, justificando nossa preferência por esse tipo. Pretendemos ainda, no capítulo seguinte, de análise interpretativa dessas igrejas, comparar as características levantadas nessas construções com aspectos equivalentes identificados em edifícios gregos e romanos.

Quanto aos elementos decorativos encontramos muitos dados e descrições dos mosaicos nos pisos e paredes, mas por causa do estado de destruição de muitas dessas igrejas, pouca coisa é mostrada. Como mencionamos na introdução, optamos por não nos aprofundarmos na questão dos mosaicos nesse trabalho por acreditarmos que esse material apresenta uma riqueza de informações que não seria possível explorar de maneira adequada aqui, pois o seu estudo, a nosso ver, não se enquadra na proposta inicial dessa dissertação. Na decoração, procuramos dar especial atenção aos capitéis por entendermos que são a marca da permanência de elementos da arquitetura clássica nessas igrejas. No decorrer do desenvolvimento das pesquisas para a elaboração do trabalho tivemos escassez de informações que nos fornecessem uma descrição desses elementos nas igrejas que fazem parte do catálogo. Porém, apesar da parca informação a respeito dos capitéis, julgamos conveniente apresentar os dados que conseguimos a respeito para elaborarmos uma análise crítica no capítulo seguinte, pois o capitel foi um elemento que destacamos desde o início desse trabalho, ainda na fase de projeto de pesquisa.

Procuramos definir um padrão de apresentação que fosse capaz de mostrar de maneira 
concisa e organizada as informações encontradas de forma bastante heterogênea. Deste modo elaboramos uma ficha catalográfica na qual constam, para cada igreja, os dados mais importantes para o desenvolvimento de nossas análises. As informações presentes nessa tabela são:

1) Local: é o nome do sítio onde foi registrada a presença de uma ou mais igrejas. Como nome do local foi adotado aquele usado como verbete na TNEAEHL e para aquelas igrejas que levantamos a partir da obra ACR foi usado o nome do local como aparece no texto. Para apresentação do catálogo optamos seguir o modo adotado na TNEAEHL, isto é, a organização por ordem alfabética, em que o nome do local é o dado de entrada do catálogo;

2) Nome da igreja: esse campo é preenchido somente se a igreja tem um nome, ou quando existe mais de uma igreja no mesmo local, a fim de que elas possam ser identificadas. Usualmente, quando há mais de uma, elas são nomeadas em função de sua posição na cidade e a orientação cardeal. Assim encontramos em várias cidades igrejas chamadas de Igreja Sul ou Igreja Leste, por exemplo. No catálogo, quando apresentarmos mais de uma igreja sem nome no mesmo local, optamos por numerá-las seqüencialmente: Igreja 1 , Igreja 2, etc.

3) Tipo: procuramos determinar os "tipos" das igrejas (arqueologicamente falando), usando como principal critério sua forma na planta. Assim, foi estabelecido um critério constituído pelos seguintes "tipos":

3.a. Basílica: igreja em forma de corredor, de estrutura longilínea, dividida em nave central e naves laterais por fileiras de colunas. $\mathrm{O}$ acesso se faz por um dos lados curtos, e a extremidade oposta termina em uma ou mais absides, tendo a principal, geralmente, uma largura próxima da nave central. Dentro da tipologia da basílica podemos ter alguns subtipos: 3.a.1. Basílica monoabsidal: É a basílica que tem em sua extremidade apenas uma abside, geralmente da largura da nave central;

3.a.2. Basílica triabsidal: é o tipo de basílica que tem três absides, uma na extremidade de cada nave.

3.a.3. Basílica com transepto: esse tipo de basílica tem, além das naves laterais, um espaço anexo a elas próximo à abside.

3.b. Cruciforme: igreja de estrutura longilínea, onde o corredor principal é cortado por outro corredor perpendicular à ele, geralmente menor que o principal, na sua extremidade, próximo à abside. A planta dessa igreja tem a forma de uma cruz e por esse motivo é chamada de cruciforme;

3.c. Octogonal: igreja que tem na planta a forma de um octógono, polígono de oito lados;

3.d.Circular: igreja que tem na planta a forma de um círculo.

4) Orientação: nesse campo procuramos informar a orientação das igrejas em relação aos pontos cardeais. Naquelas reunidas no catálogo, e com a possibilidade de identificar esse dado, foram encontradas três situações de orientação:

4.a. Leste-oeste: é a situação onde o altar fica a leste e a entrada da igreja à oeste;

4.b. Oeste-leste: é o oposto da situação anterior, quando o altar da igreja está a oeste e a entrada à leste;

4. c. Norte-sul: nessas igrejas, encontramos o altar ao norte e a entrada ao sul.

5) Dimensões: são informadas as dimensões gerais da igreja, dadas ou extraídas a partir da escala gráfica, quando esta consta na sua representação. Normalmente, no caso das basílicas, essas dimensões correspondem ao tamanho da nave, juntamente com a(s) abside(s);

6) Datação: refere-se à época de construção da igreja, ou ao seu período de existência. Esse catálogo apresenta as 
igrejas construídas durante o recorte temporal adotado, que corresponde ao primeiro movimento de construção no cristianismo - séculos IV a VI d.C.

7) Elemento de datação: indicamos qual foi o elemento que estabeleceu a cronologia da igreja, quando nos é informado;

8) Capitéis: neste ítem procuramos destacar a ocorrência de capitéis nas igrejas que fazem parte do catálogo. Naquelas onde conseguimos obter esse dado, indicamos a ordem do capitel, tomando como referência as três ordens gregas - dórica, jônica e coríntia. Quando o estilo do capitel não se enquadra nessas ordens, apresentamos uma breve descrição dele.

9) Informações complementares: aqui são expostas informações não apresentadas nos outros ítens da ficha catalográfica e que julgamos importantes para a compreensão de cada um dos edifícios nas suas particularidades. Esse campo pode trazer detalhes sobre os estágios de ocupação e reforma dos edifícios, e quando a ficha da igreja não trouxer nenhuma imagem fornecemos nesse espaço alguma descrição a respeito dessa igreja, a fim de que o leitor consiga ter uma noção mínima da sua configuração;

10) Bibliografia: esse campo se restringe a apresentar, nas duas obras usadas como nossas fontes arqueológicas - TNEAEHL e ACR - as páginas onde podem ser encontradas as informações de cada igreja;

11) Arquivo: apresenta alguma imagem da igreja, se existir. Exibe preferencialmente uma planta ou uma perspectiva isométrica, mas na falta desse tipo de representação também pode mostrar uma foto que auxilie na compreensão do espaço da igreja.

O catálogo será apresentado por ordem alfabética do lugar de estabelecimento dessas igrejas. Essa opção foi a preferida porque acreditamos que adotar uma ordem aleatória, como a alfabética, seria mais adequado do que estabelecer numeração seqüencial para as igrejas.
Não adotando nenhuma classificação rígida para a apresentação de nosso objeto de estudo temos maior liberdade para, por meio dos gráficos e tabelas comparativas apresentados na sequiência do catálogo, trabalhar com as várias classificações possíveis do documento. Também foi opção nossa adotar uma numeração em fichas para o catálogo, destacando-o do restante da dissertação, entendendo essa parte como uma ferramenta auxiliar, porém fundamental, para o aprofundamento das questões levantadas ao longo desse trabalho.

Naturalmente não são todas as igrejas que fazem parte desse catálogo que preenchem com informações todos os itens da ficha catalográfica. Por exemplo, nem todas as igrejas têm um nome. Também aconteceu de não termos acesso às imagens de alguns dos edifícios que fazem parte do catálogo, apesar de disporem de uma descrição que nos trouxe informações suficientes para compreendermos sua configuração espacial. Quando tivemos acesso às imagens, em desenho ou fotos, optamos por apresentar no catálogo as perspectivas, quando disponíveis, ou as plantas, tendo como última opção a apresentação de fotos, procurando sempre selecionar imagens a partir das quais fosse possível compreender como o espaço se configura em cada edifício.

Consideramos necessário um conjunto mínimo de informações para que a igreja pudesse ser incluída no catálogo, e assim excluímos algumas que não tinham essas informações, buscando criar um corpo de documentos que nos apoiasse nas análises que pretendemos realizar sobre o assunto e não apenas elaborar um compêndio das igrejas da região no período estudado. As informações mínimas que julgamos necessárias para incluir a igreja em nosso catálogo são: o tipo e a datação, pois será essencialmente a partir dessas informações que estabeleceremos comparações e desenvolveremos análises sobre elas. Outras informações, tais como a existência de um desenho em planta ou as dimensões, apesar de serem dados importantes para o aprofundamento de nossas interpretações não foram considerados como um fator exclusivo na elaboração desse catálogo. 
Ao organizarmos esse banco de dados tomamos cuidado especial com uma categoria de igrejas, que são as que fazem parte de mosteiros. Os que encontramos na região da Palestina em época bizantina são normalmente estruturas isoladas, que ficam afastados dos centros urbanos. Alguns deles têm igrejas, outros, pequenas capelas. As estruturas que caracterizam a igreja inserida em um mosteiro por vezes são difíceis de serem identificadas ao se analisar as plantas dos mosteiros como um todo. Em face dessa dificuldade optamos por incluir no catálogo raros exemplos, onde as estruturas das igrejas estão destacadas de maneira clara no complexo arquitetônico de um mosteiro ou a própria bibliografia consul- tada destaca somente a igreja e a apresenta de forma isolada do complexo.

Antes de apresentarmos o catálogo das igrejas estudadas, julgamos conveniente mostrar um mapa de localização e distribuição delas na região da Palestina, juntamente com uma tabela que apresenta a quantidade de igrejas por localidade.

No final desse capítulo colocamos à disposição informações a respeito da tipologia das igrejas, sua distribuição por época, as orientações mais usadas, suas proporções e ocorrência de elementos decorativos clássicos obtidas a partir do catálogo e organizadas em gráficos e tabelas, que serão analisados criticamente no capítulo seguinte. 
Mapa de localização das igrejas

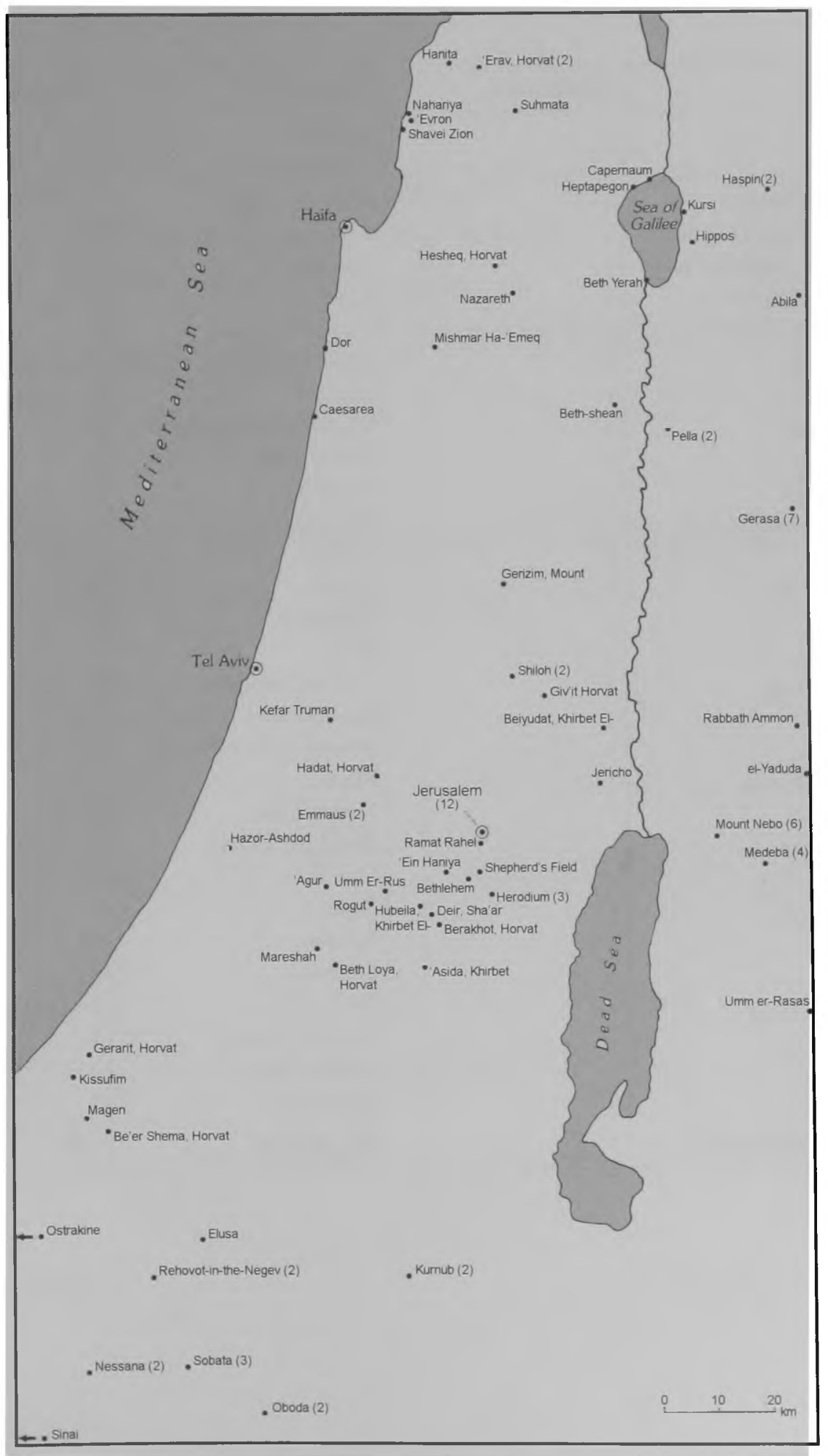




\section{Relação dos locais que constam no mapa}

\begin{tabular}{|l|l|}
\hline Local & Quantidade \\
\hline Abila & 1 \\
'Agur & 1 \\
'Asida, Khirbet & 1 \\
Be'er Shema, Horvat & 1 \\
Beiyudat, Khirbet El- & 1 \\
Berakhot, Horvat & 1 \\
Beth Loya, Horvat & 1 \\
Beth Yerah & 1 \\
Bethlehem & 1 \\
Beth-shean & 1 \\
Caesarea & 1 \\
Capernaum & 1 \\
Deir, Sha'ar & 1 \\
Dor & 1 \\
'Ein Haniya & 1 \\
Elusa & 1 \\
Emmaus & 2 \\
'Erav, Horvat & 2 \\
'Evron & 1 \\
Galilee & 1 \\
Gerarit, Horvat & 1 \\
Gerasa & 7 \\
Gerizim, Mount & 1 \\
Giv'it Horvat & 1 \\
Hadat, Horvat & 1 \\
Hanita & 1 \\
Haspin & 2 \\
Hazor-Ashdod & 1 \\
Heptapegon & 1 \\
Herodium & 3 \\
Hippos & 1 \\
Hubeila, Khirbet El- & 1 \\
\hline
\end{tabular}

\begin{tabular}{|l|l|}
\hline Local & Quantidade \\
\hline Jericho & 1 \\
Jerusalém & 12 \\
Kefar Truman & 1 \\
Kissufim & 1 \\
Kurnub & 2 \\
Kursi & 1 \\
Magen & 1 \\
Mareshah & 1 \\
Medeba & 4 \\
Mishmar Ha-'Emeq & 1 \\
Mount Nebo & 6 \\
Nahariya & 1 \\
Nazareth & 1 \\
Nessana & 2 \\
Oboda & 2 \\
Ostrakine & 1 \\
Pella & 2 \\
Rabbath Ammon & 1 \\
Ramat Rahel & 1 \\
Rehovot-in-the-Negev & 2 \\
Rogut & 1 \\
Shavei Zion & 1 \\
Shepherd's Field & 1 \\
Shiloh & 2 \\
Sinai & 1 \\
Sobata & 3 \\
Suhmata & 1 \\
Tel Aviv & 1 \\
Umm Er-Rasas & 1 \\
Umm Er-Rus & 1 \\
Yaduda, El & 1 \\
\hline Total geral & $\mathbf{1 0 1}$ \\
\hline
\end{tabular}


Catálogo das igrejas paleocristãs na Palestina

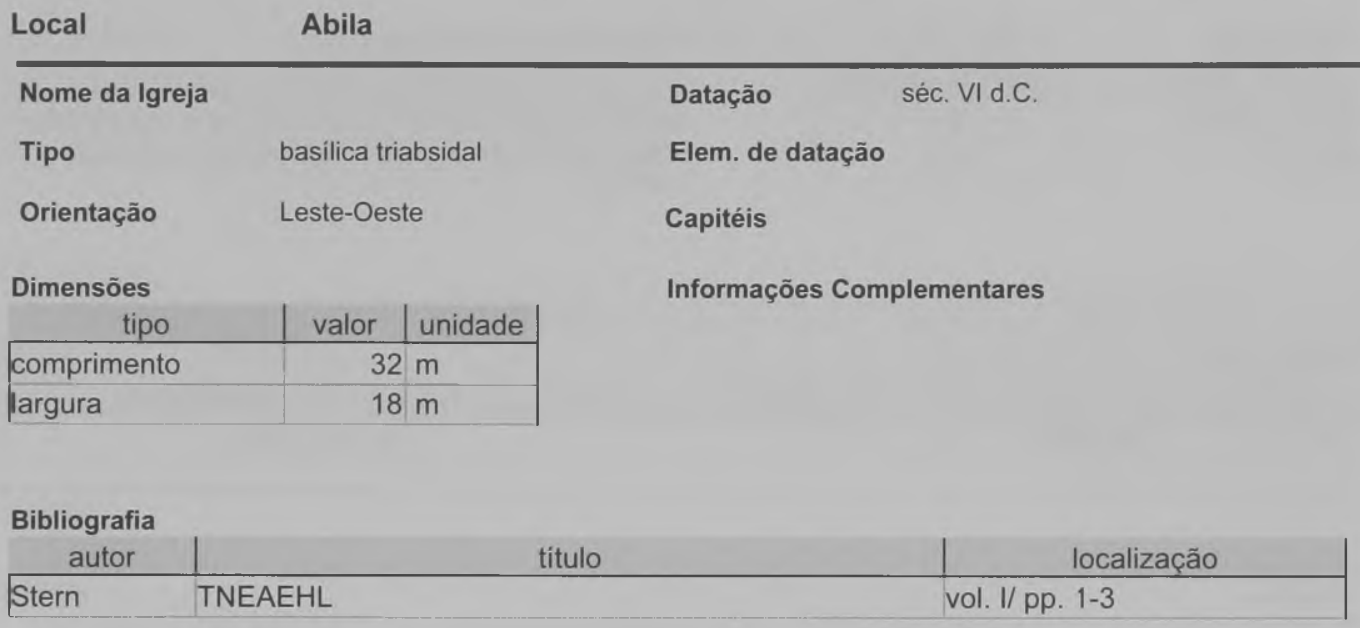

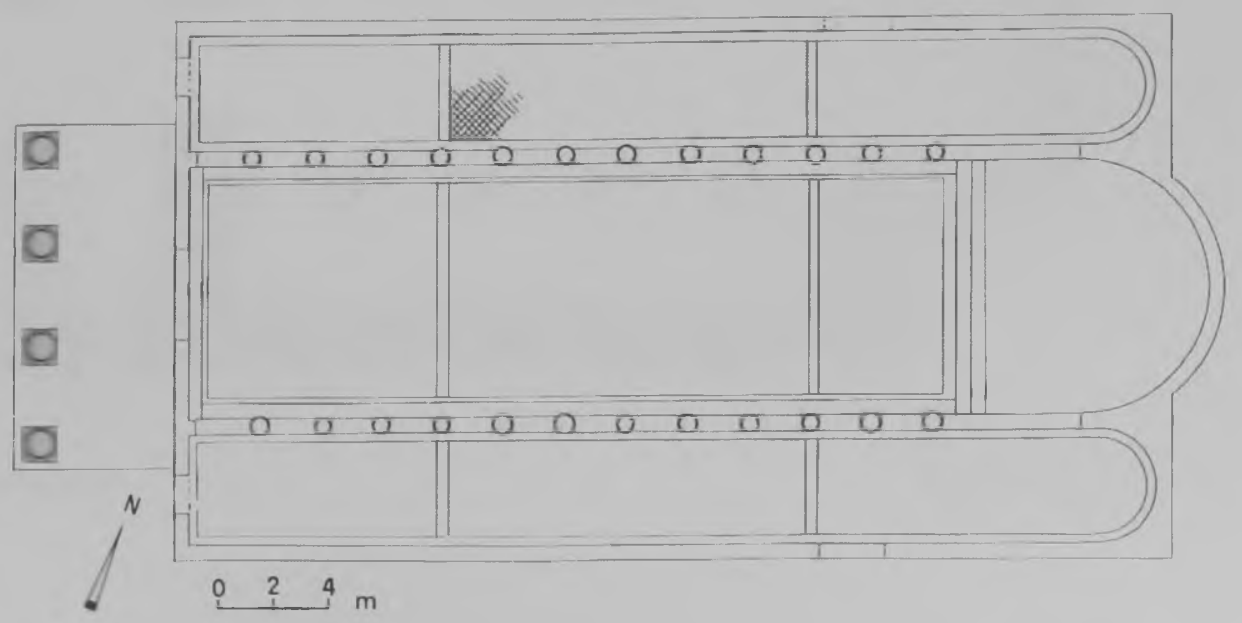




\section{Local 'Agur}

\begin{tabular}{|c|c|c|}
\hline \multicolumn{3}{|c|}{ Nome da Igreja } \\
\hline Tipo & \multicolumn{2}{|c|}{ basilica monoabsidal } \\
\hline \multicolumn{3}{|l|}{ Orientação } \\
\hline Dimensões & & \\
\hline tipo & valor & unidade \\
\hline comprimento & \multicolumn{2}{|c|}{$13 \mathrm{~m}$} \\
\hline largura & \multicolumn{2}{|c|}{$10 \mathrm{~m}$} \\
\hline
\end{tabular}

Datação

fim do séc. IV/ início do séc. V d.C.

Elem. de datação

\section{Capitéis}

\section{Informações Complementares}

A igreja tem uma abside semicircular externa, com 2,7 m de raio. Ligada à parede sul dessa igreja foi encontrada uma pequena câmara, com fragmentos de uma pia batismal.

\section{Bibliografia}

\begin{tabular}{|l|l|l|}
\multicolumn{1}{c|}{\begin{tabular}{c}
\multicolumn{1}{c}{ autor } \\
Stern
\end{tabular}} & TNEAEHL & \multicolumn{1}{c|}{ localização } \\
\hline
\end{tabular}




\section{Local 'Asida, Khirbet}

Nome da Igreja

Tipo

basilica monoabsidal

Orientação

Dimensões

\begin{tabular}{|l|r|l|}
\multicolumn{1}{c|}{ tipo } & valor & unidade \\
\hline Comprimento & 12 & $\mathrm{~m}$ \\
\hline largura & 9 & $\mathrm{~m}$ \\
\hline
\end{tabular}

Datação

séc. V ou VI d.C.

Elem. de datação

Capitéis

Informações Complementares

\section{Bibliografia}

\begin{tabular}{|l|l|l|}
\multicolumn{1}{c|}{ autor } & titulo & \multicolumn{1}{c|}{ localização } \\
\hline Stern & TNEAEHL & vol. I/p. 309 \\
\hline
\end{tabular}

\section{Arquivo}

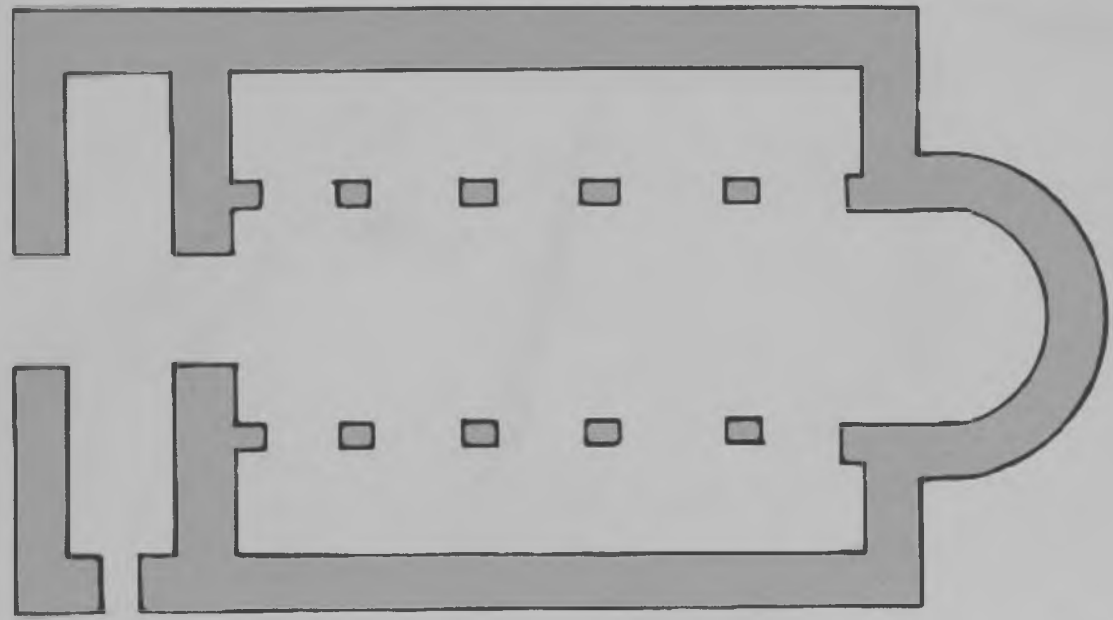


Local Be'er Shema, Horvat

\section{Nome da Igreja}

Tipo

basílica monoabsidal

Orientação

Dimensões

\begin{tabular}{|l|r|l|}
\multicolumn{1}{c|}{ tipo } & valor & unidade \\
\hline Comprimento & 21 & $\mathrm{~m}$ \\
\hline largura & 12,5 & $\mathrm{~m}$ \\
\hline
\end{tabular}

\section{Datação final do séc. VI d.C.}

Elem. de datação mosaicos e moedas

\section{Capitéis}

\section{Informações Complementares}

Junto à parede sul da igreja haviam outras três salas. $\mathrm{Na}$ sala mais a oeste, usada como batistério, foi encontrada uma pia batismal semicircular.

\begin{tabular}{c|c|c|}
$\begin{array}{c}\text { Bibliografia } \\
\text { autor }\end{array}$ & título & \multicolumn{1}{c|}{ localização } \\
\hline Tsafrir & ACR & pp. 273-276 \\
\hline
\end{tabular}

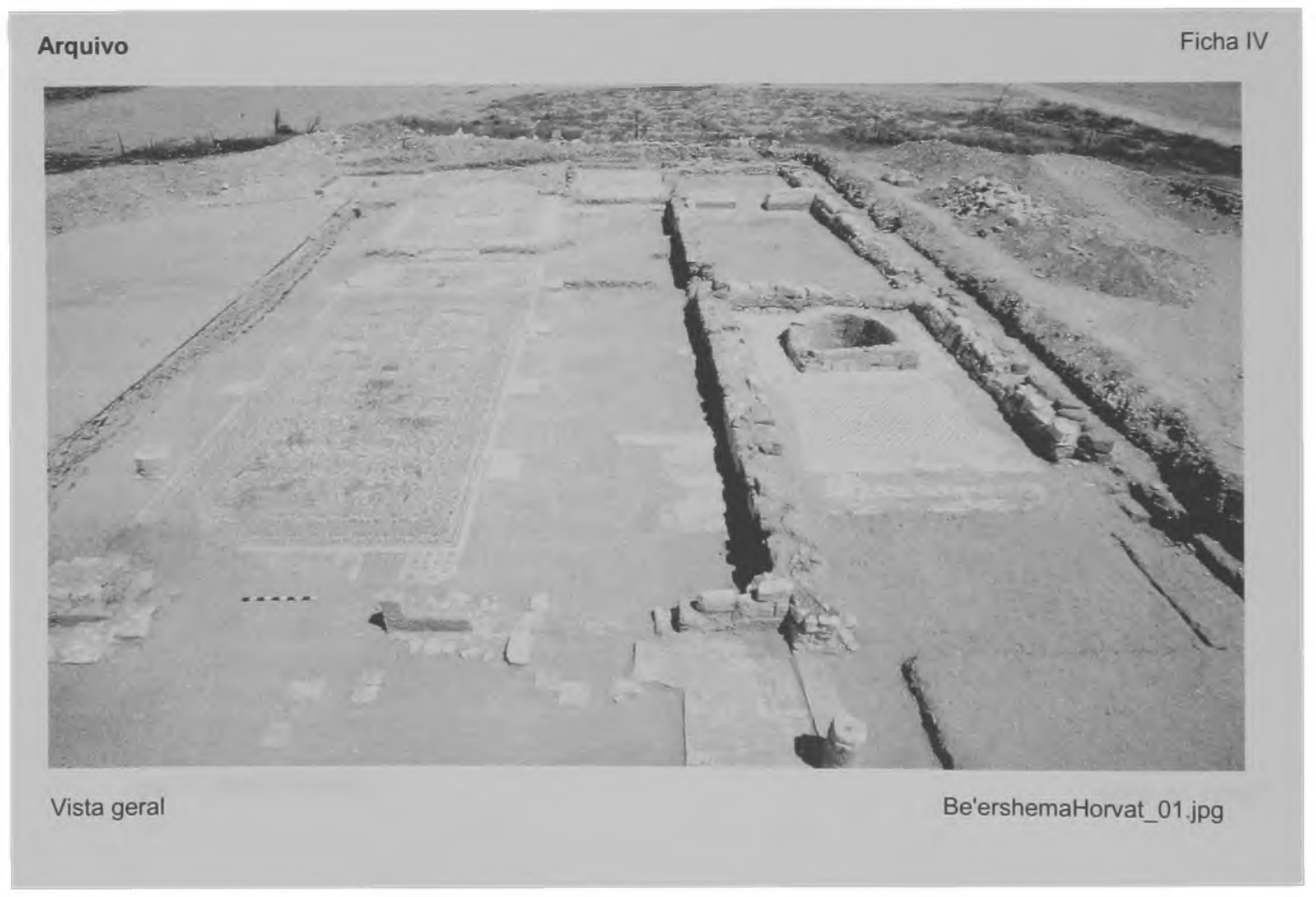


Local

Beiyudat, Khirbet El-

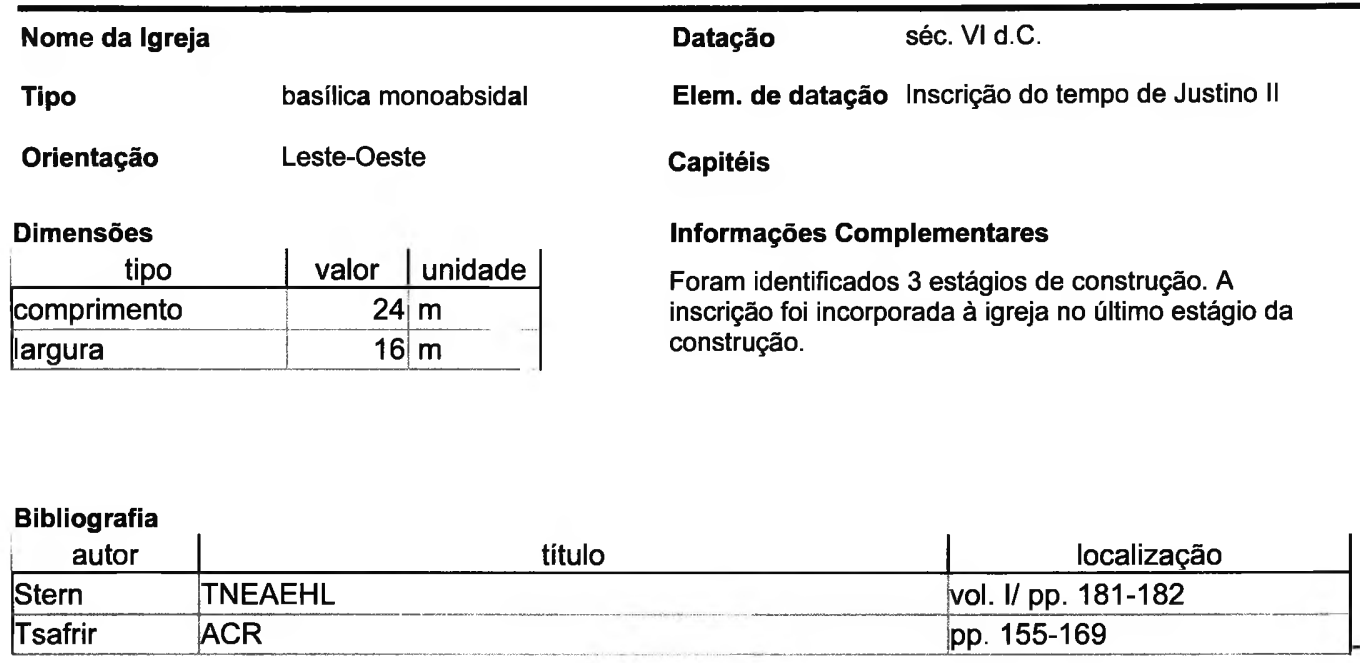

Arquivo

Ficha V

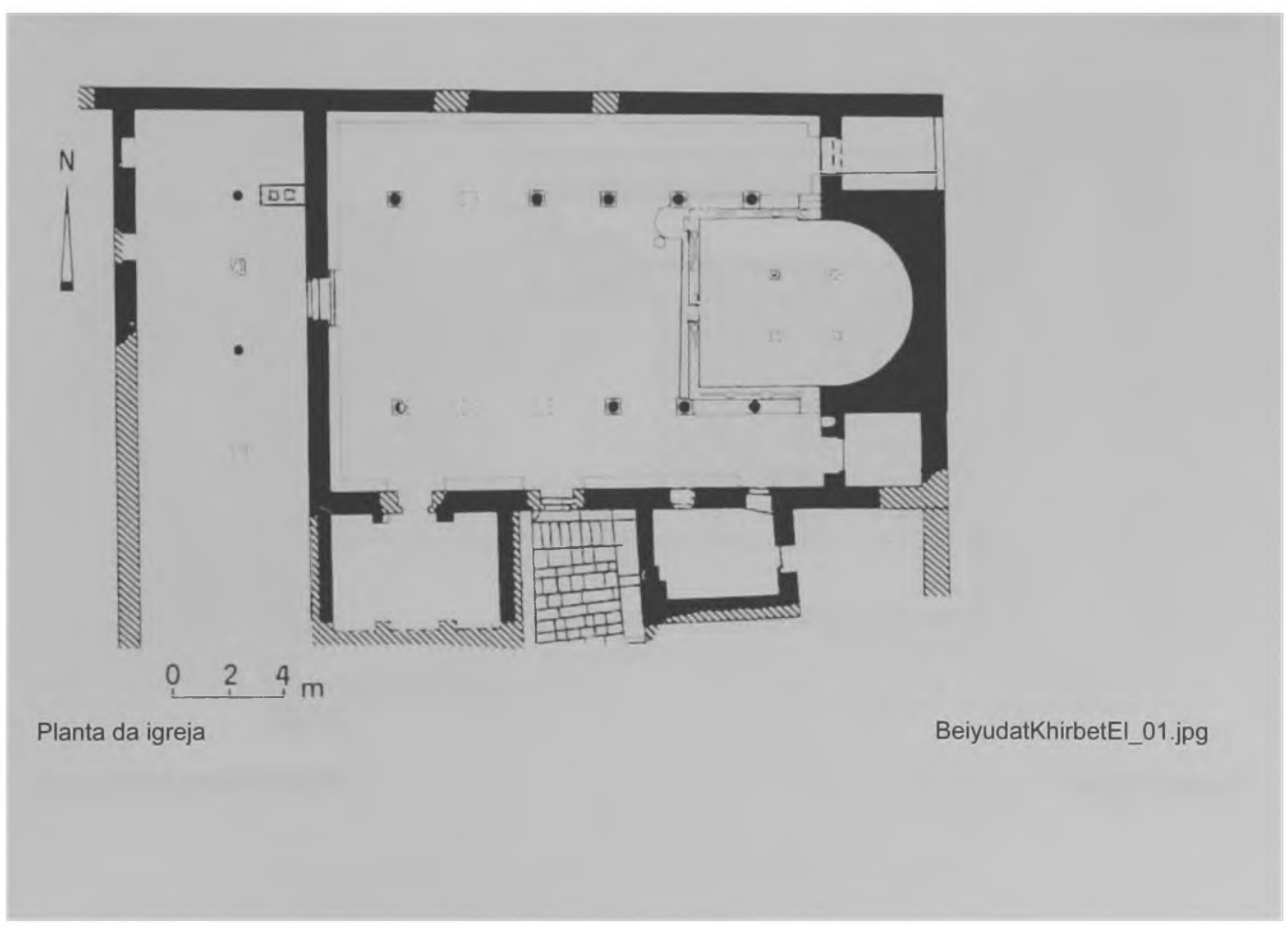




Local Berakhot, Horvat

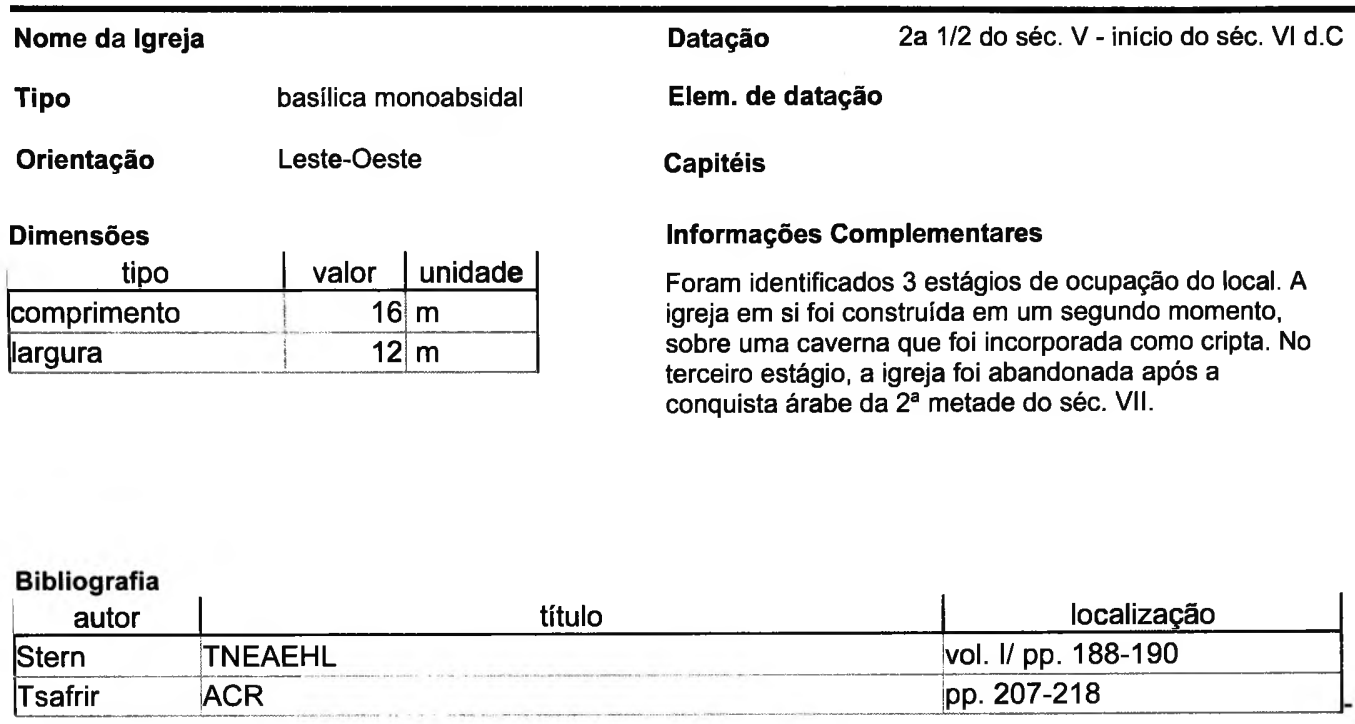

\section{Arquivo}

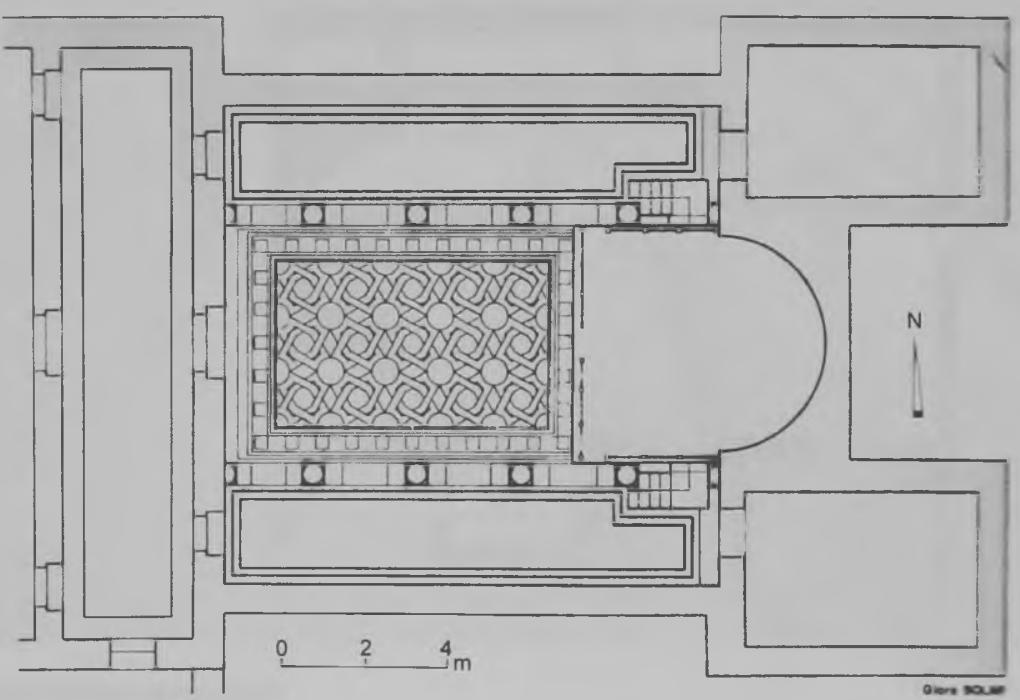

Planta da igreja

BerakhotHorvat_01.jpg 
Local

Beth Loya, Horvat

\section{Nome da Igreja}

Tipo

Orientação

basílica monoabsidal

Dimensōes

\begin{tabular}{|l|r|l|}
\multicolumn{1}{c|}{ tipo } & valor & unidade \\
\hline Comprimento & 20,4 & $\mathrm{~m}$ \\
\hline largura & $13,9 \mathrm{~m}$ \\
\hline
\end{tabular}

Datação

cerca de 500 d.C.

Elem. de datação

Capitéis face plana

\section{Informaçōes Complementares}

Possui nártex e átrio. A abside da igreja é interna, com uma sala retangular de cada lado.

Junto à basilica há uma capela ao norte e um batistério ao sul.

\begin{tabular}{|l|l|l|}
$\begin{array}{c}\text { Bibliografia } \\
\text { autor }\end{array}$ & \multicolumn{1}{c|}{ título } & \multicolumn{1}{c|}{ localização } \\
\hline Stern & TNEAEHL & vol. I/ pp. 210-213 \\
\hline Tsafrir & ACR & pp. 265-272 \\
\hline
\end{tabular}




\section{Local Beth Yerah}

\begin{tabular}{|c|c|}
\hline Nome da Igreja & \\
\hline Tipo & basílica triabsidal \\
\hline Orientação & \\
\hline Dimensões & \\
\hline tipo & valor unidade \\
\hline comprimento & $12,5 \mathrm{~m}$ \\
\hline |largura & $11,5 \mathrm{~m}$ \\
\hline
\end{tabular}

Datação

primeira metade do séc. $V$ d.C.

Elem. de datação

\section{Capitéis}

\section{Informações Complementares}

A igreja possui à sua frente um átrio retangular, medindo $21 \times 10.5 \mathrm{~m}$

\begin{tabular}{|l|l|l|}
$\begin{array}{c}\text { Bibliografia } \\
\text { autor }\end{array}$ & titulo & \multicolumn{1}{c|}{ localização } \\
\hline Stern & TNEAEHL & vol. I/ pp. 255-259 \\
\hline
\end{tabular}

\section{Arquivo}
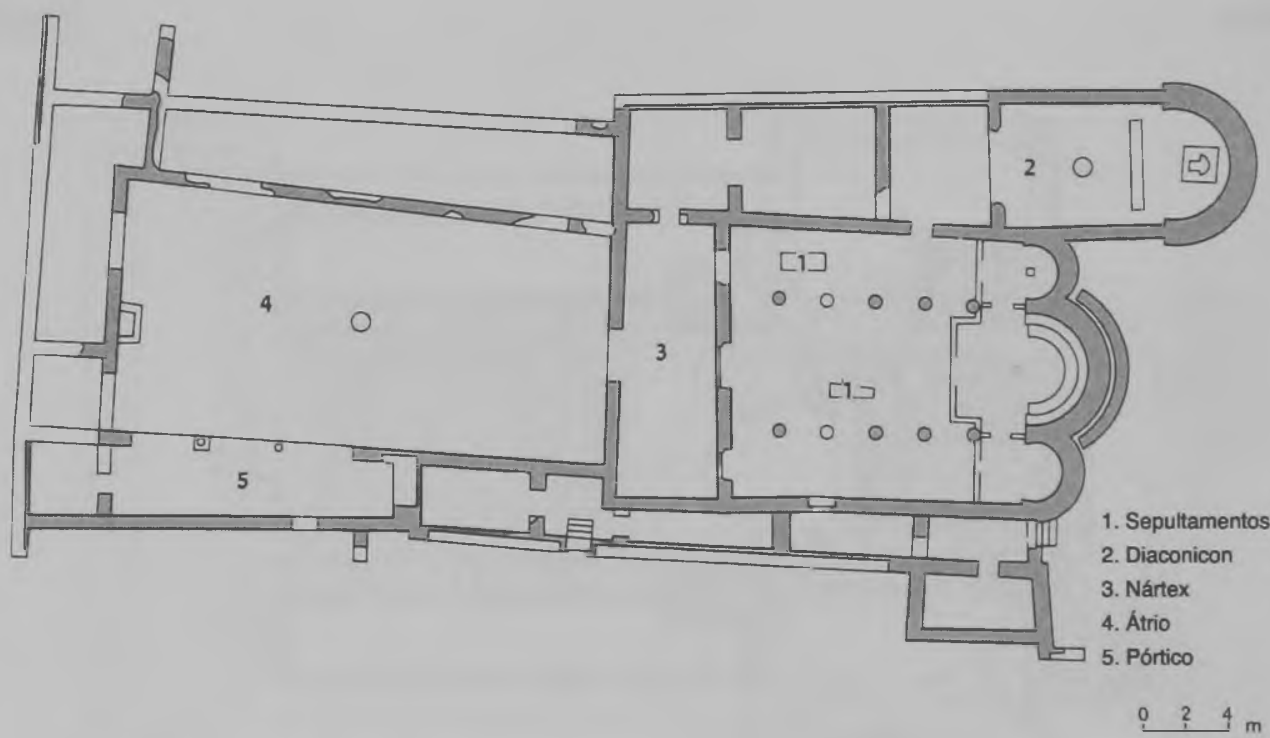
Bethlehem

\begin{tabular}{|c|c|c|}
\hline Nome da Igreja & Igreja da Natividade & séc. IV (fase 1) e séc. VI d.C. (fase 2) \\
\hline Tipo & basilica monoabsidal & Elem. de datação \\
\hline Orientação & Leste-Oeste & Capitéis \\
\hline Dimensões & & Informações Complementares \\
\hline tipo & valor unidade & \multirow{3}{*}{$\begin{array}{l}\text { Nessa igreja a forma da basílica é associada a uma } \\
\text { estrutura memorial, onde se localiza o altar. Durante o } \\
\text { governo de Justiniano I a igreja foi reestruturada, tendo } \\
\text { seu comprimento aumentado para } 33 \mathrm{~m} \text { e a área do altar } \\
\text { passou a ter a forma de abside tripla. }\end{array}$} \\
\hline comprimento & $26,5 \mathrm{~m}$ & \\
\hline largura & $26,5 \mathrm{~m}$ & \\
\hline
\end{tabular}

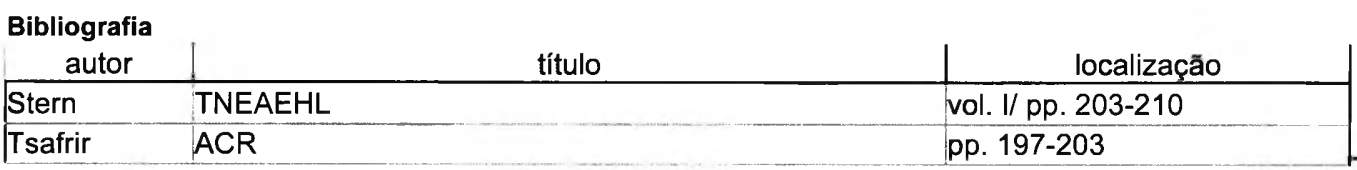

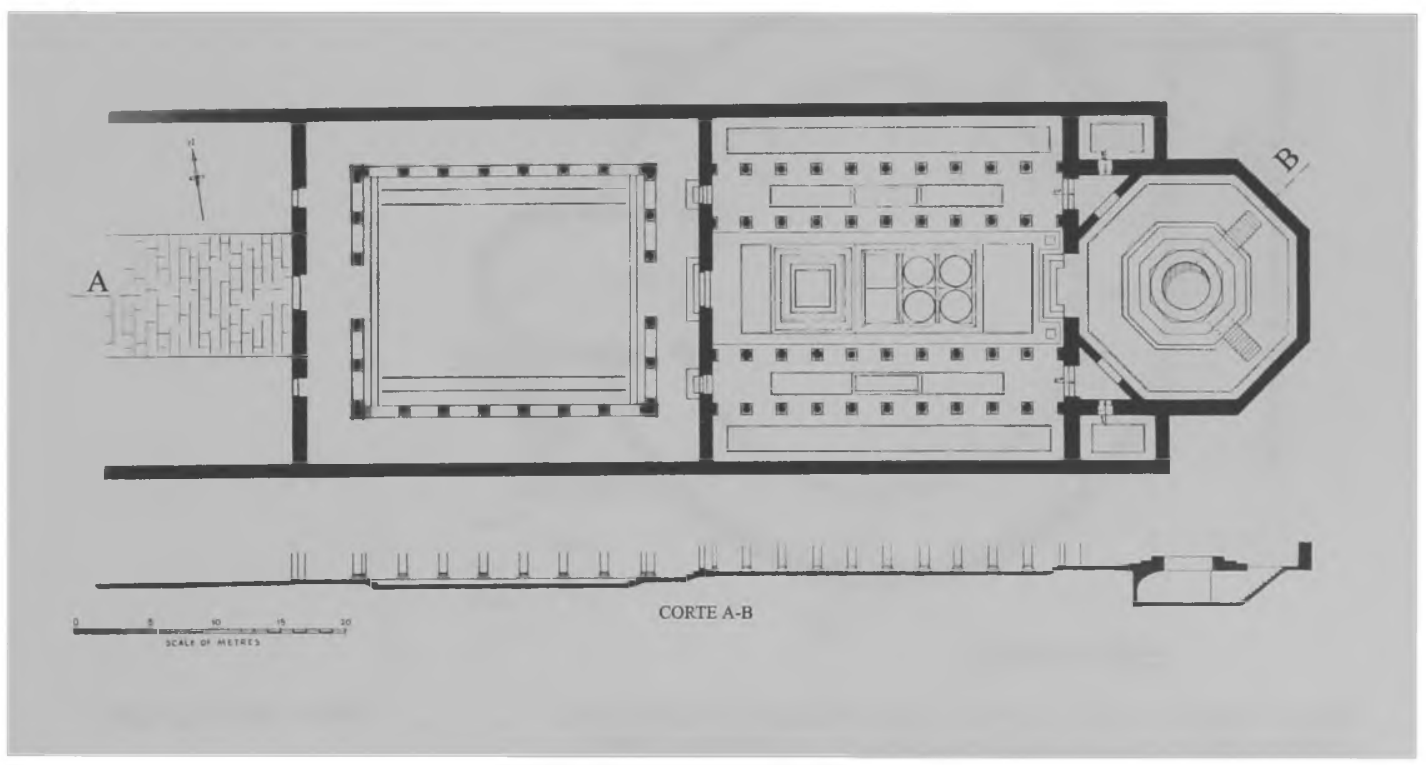

A Igreja da Natividade na época de Constantino: planta baseada em Bethlehem_11.jpg escavaçōes, e um corte mostrando os niveis do piso. 


\section{Local Beth-shean}

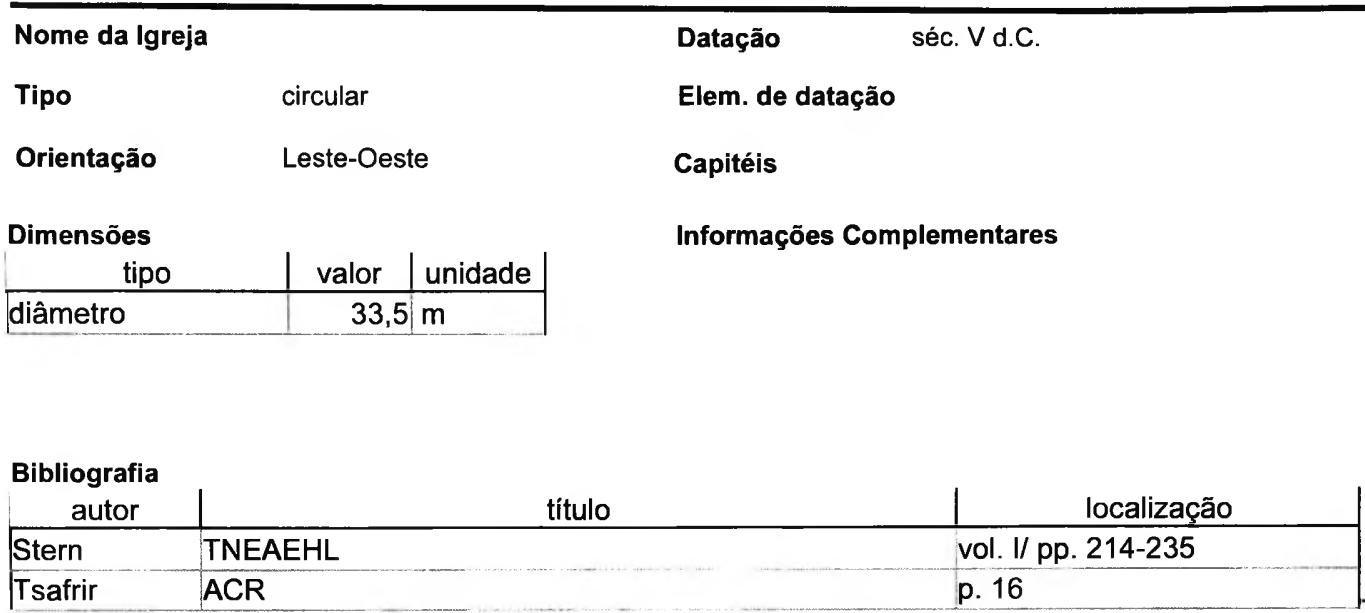

\section{Arquivo}

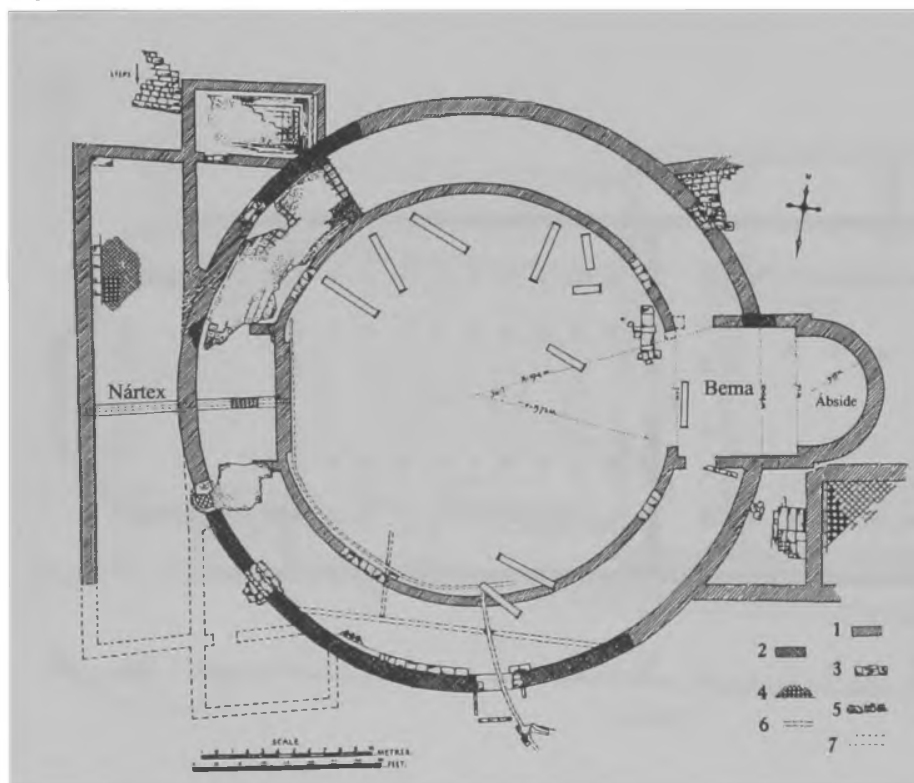

Igreja redonda: a planta concêntrica (reconstituição provável de sua configuração no século VI d.C.) compreende um estilóbato interno.

Legenda - 1) paredes de fundação; 2) paredes elevadas no nivel do pavimento; 3 ) lajes de piso do pavimento; 4) piso quadriculado em vermelho e branco; 5) fragmentos de mosaico; 6) tubulaçōes subterrâneas; 7) paredes reconstituídas. 
Local Caesarea

Nome da Igreja

Tipo

octogonal

Orientação

Dimensões

\begin{tabular}{|l|c|c|}
\multicolumn{1}{|c|}{ tipo } & valor & unidade \\
\hline diâmetro & 38,8 & $\mathrm{~m}$ \\
\hline
\end{tabular}

Datação

séc. VI d.C.

Elem. de datação

Capitéis

Informações Complementares

Bibliografia

\begin{tabular}{|l|c|c|}
$\begin{array}{c}\text { autor } \\
\text { Stern }\end{array}$ & titulo & localização \\
\hline
\end{tabular}


Formas Arquitetônicas Clássicas em Edifícios Religiosos do Período Bizantino.

Revista do Museu de Arqueologia e Etnologia, São Paulo, Suplemento 5, 2008.

Local Capernaum

\begin{tabular}{|c|c|c|}
\hline Nome da Igreja & & Datação primeira metade do séc. $\vee$ d.C. \\
\hline Tipo & octogonal & Elem. de datação objetos encontrados na escavação \\
\hline Orientação & & Capitéis \\
\hline Dimensões & & Informações Complementares \\
\hline tipo & \begin{tabular}{l|l} 
valor & unidade \\
\end{tabular} & A igreja foi construida no local onde havia anteriormente \\
\hline diâmetro & $16,53 \mathrm{~m}$ & $\begin{array}{l}\text { uma "domus ecclesia", conhecida como casa de Simão- } \\
\text { Pedro, que existiu entre os sécs. I a IV d. C. } \\
\text { Foi a primeira igreja de planta octogonal a ser construida } \\
\text { na Palestina. Originalmente o edifício não tinha abside, } \\
\text { que foi adicionada posteriormente, juntamente com uma } \\
\text { pia batismal. }\end{array}$ \\
\hline
\end{tabular}

Bibliografia
\begin{tabular}{|l|l|l|}
\multicolumn{1}{c|}{ autor } & titulo & \multicolumn{1}{c|}{ localização } \\
\hline Stern & TNEAEHL & vol. I./ pp. 291-296 \\
\hline Tsafrir & ACR & pp. 71-76 \\
\hline
\end{tabular}

\section{Arquivo}

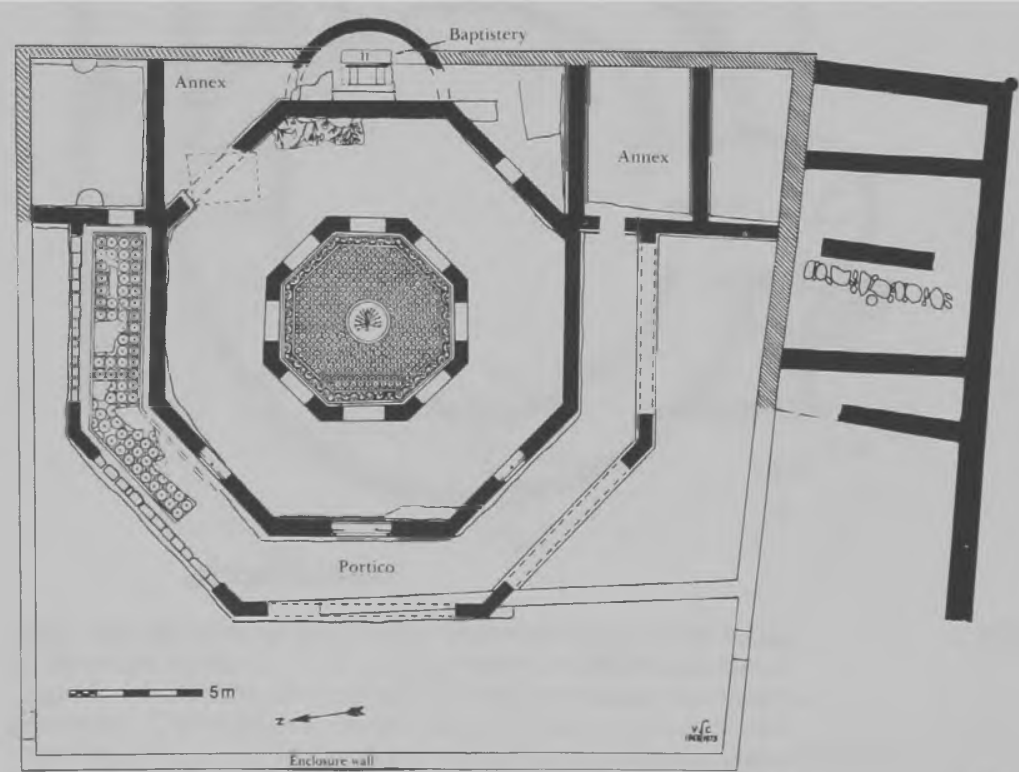

Igreja octogonal construida sobre a "domus ecclesia" no séc. V d.C. 


Local Deir, Sha'ar

\section{Nome da Igreja}

Tipo

basilica monoabsidal

Orientação

Dimensões
Datação

Elem. de datação

\section{Capitéis}

Informações Complementares

Igreja com abside inscrita.

final do séc. VI d.C. 


Local Dor

\begin{tabular}{|c|c|c|}
\hline Nome da Igreja & Dora-Dor & século IV d. C. \\
\hline Tipo & basilica monoabsidal & Elem. de datação moeda da época de Constantino II \\
\hline Orientação & Leste-Oeste & Capitéis \\
\hline Dimensões & & Informações Complementares \\
\hline tipo & valor $\mid$ unidade & \multirow{3}{*}{$\begin{array}{l}\text { Esta igreja é um exemplo de basílica episcopal, existente } \\
\text { em um complexo usado por peregrinos em seu caminho } \\
\text { para Jerusalém. Ela faz parte de uma estrutura de } \\
\text { estadia que se configura ao redor de um sitio religioso. }\end{array}$} \\
\hline comprimento & $18,5 \mathrm{~m}$ & \\
\hline largura & $14 \mathrm{~m}$ & \\
\hline
\end{tabular}

Bibliografia

\begin{tabular}{|l|l|l|}
\multicolumn{1}{c|}{ autor } & \multicolumn{1}{|c|}{ título } & \multicolumn{1}{c|}{ localização } \\
\hline Stern & TNEAEHL & vol. I/ pp. 357-372 \\
\hline Tsafrir & ACR & pp. 90-97 \\
\hline
\end{tabular}

\section{Arquivo}

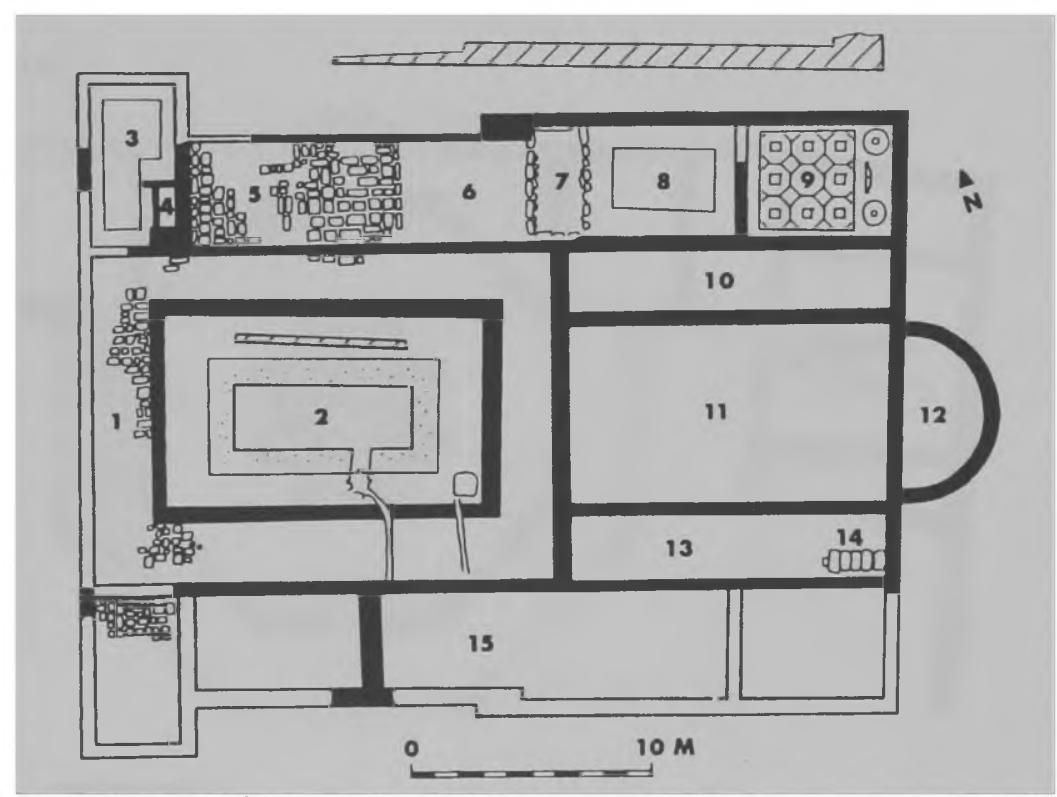

Planta da igreja - 1) Átrio; 2) Cisterna; 3) Torre noroeste (?); 4) Escada; 5) Átrio; 6) Vestíbulo; 7) Piscina; 8) Sala 1; 9) Sala 2; 10) Nave lateral norte;

11) Nave central; 12) Abside; 13) Nave lateral sul; 14) Tumba dos santos;

15) Nave lateral sul externa.
DoraDor_01.jpg 


\section{Local 'Ein Haniya}

\begin{tabular}{|c|c|c|}
\hline Nome da Igreja & & entre os séculos V e VI d.C. \\
\hline Tipo & basílica monoabsidal & Elem. de datação \\
\hline Orientação & Leste-Oeste & Capitéis \\
\hline Dimensões & & Informaçōes Complementares \\
\hline tipo & \begin{tabular}{l|l|} 
valor & unidade \\
\end{tabular} & \multirow{3}{*}{$\begin{array}{l}\text { Possui uma abside semicircular inscrita, ladeada por } \\
\text { duas salas retangulares. } \\
\text { Seu átrio possui } 10 \mathrm{~m} \text { de comprimento. }\end{array}$} \\
\hline comprimento & $15 \mathrm{~m}$ & \\
\hline largura & $10 \mathrm{~m}$ & \\
\hline $\begin{array}{c}\text { Bibliografia } \\
\text { autor }\end{array}$ & título & localização \\
\hline Stern & $\mathrm{AEHL}$ & vol. I/ pp. 309-310 \\
\hline
\end{tabular}

\section{Arquivo}
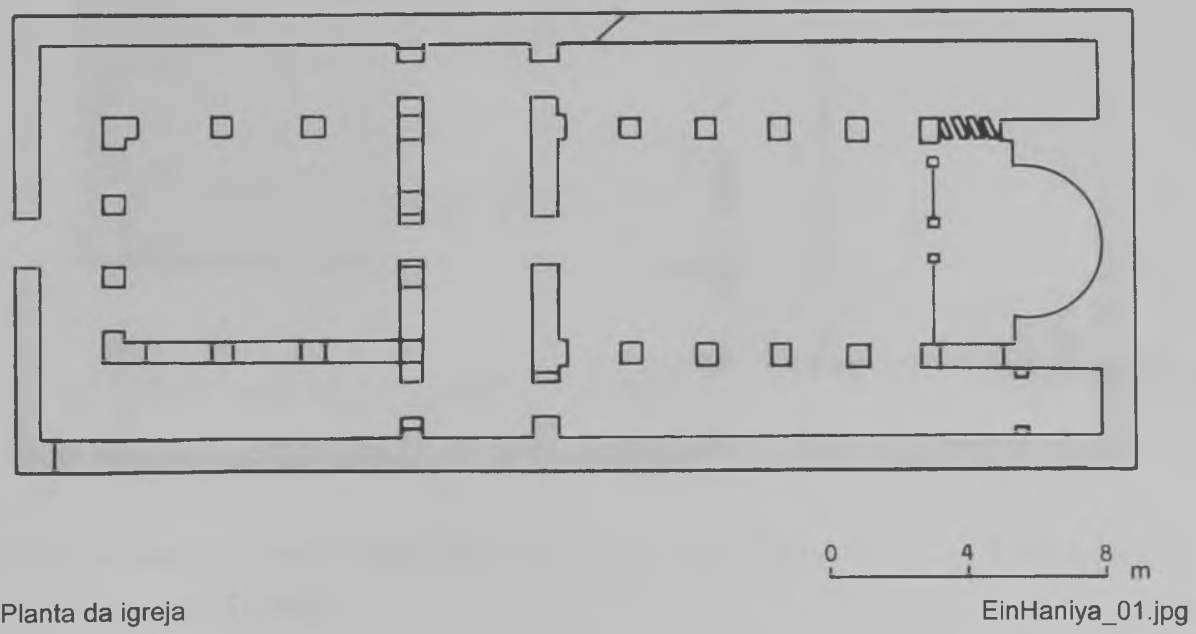
Local Elusa

\begin{tabular}{|c|c|c|}
\hline Nome da Igreja & Igreja Leste & $350-450$ d.C. \\
\hline Tipo & basilica triabsidal & Elem. de datação \\
\hline Orientação & Leste-Oeste & Capitéis \\
\hline Dimensões & & Informaçōes Complementares \\
\hline$\frac{\text { tipo }}{\text { comprimento }}$ & \begin{tabular}{c|c|} 
valor & unidade \\
39.45 & $\mathrm{~m}$
\end{tabular} & É uma das maiores igrejas da Palestina, e a maior da \\
\hline $\begin{array}{l}\text { Comprimento } \\
\text { largura } \\
\end{array}$ & \begin{tabular}{rl|l}
39,45 & $\mathrm{~m}$ \\
17,7 & $\mathrm{~m}$ \\
\end{tabular} & $\begin{array}{l}\text { região do Negev. } \\
\text { Possui um átrio, que mede } 29.6 \text { × } 32.8 \mathrm{~m} \text {. }\end{array}$ \\
\hline
\end{tabular}

\begin{tabular}{|c|c|c|}
\hline $\begin{array}{c}\text { Bibliografia } \\
\text { autor }\end{array}$ & título & localização \\
\hline Stern & TNEAEHL & vol. // pp. 379-383 \\
\hline Tsafrir & ACR & pp. 286-293 \\
\hline
\end{tabular}

\section{Arquivo}

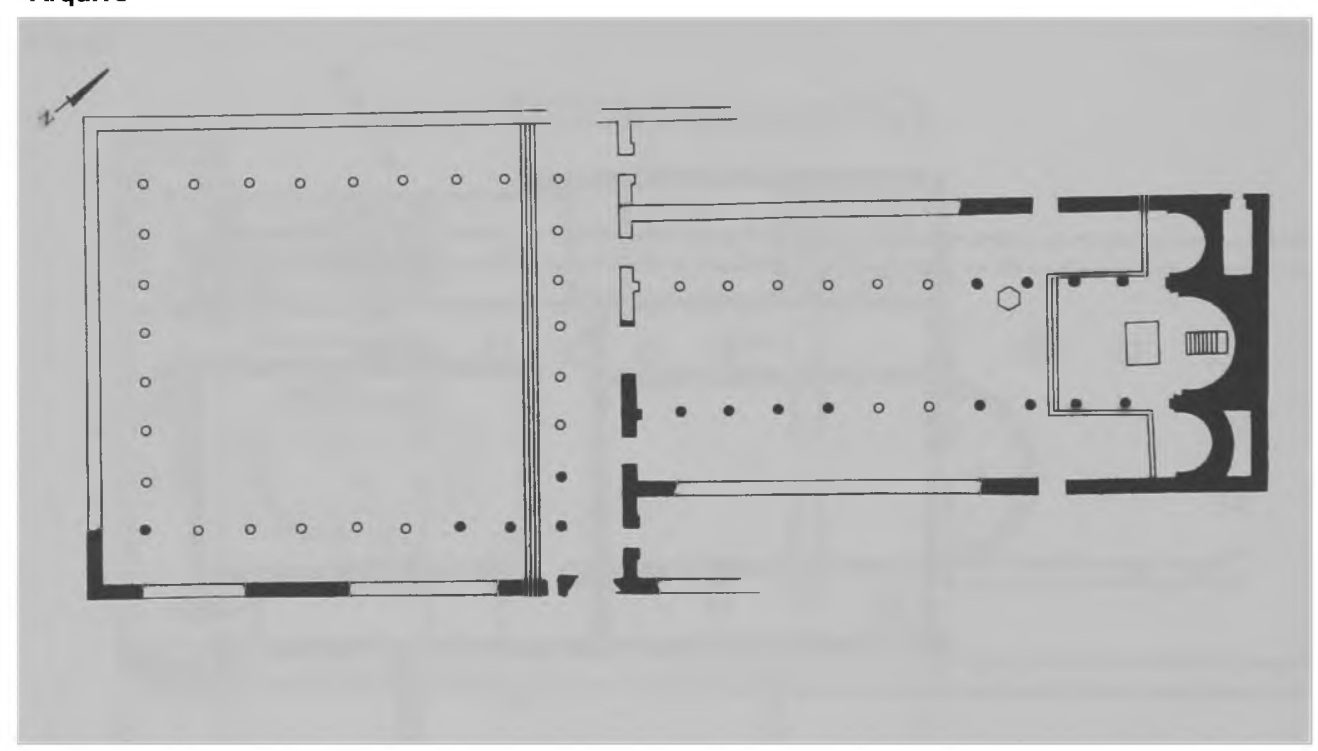

Planta da igreja

Elusa_07.jpg 
Local Emmaus

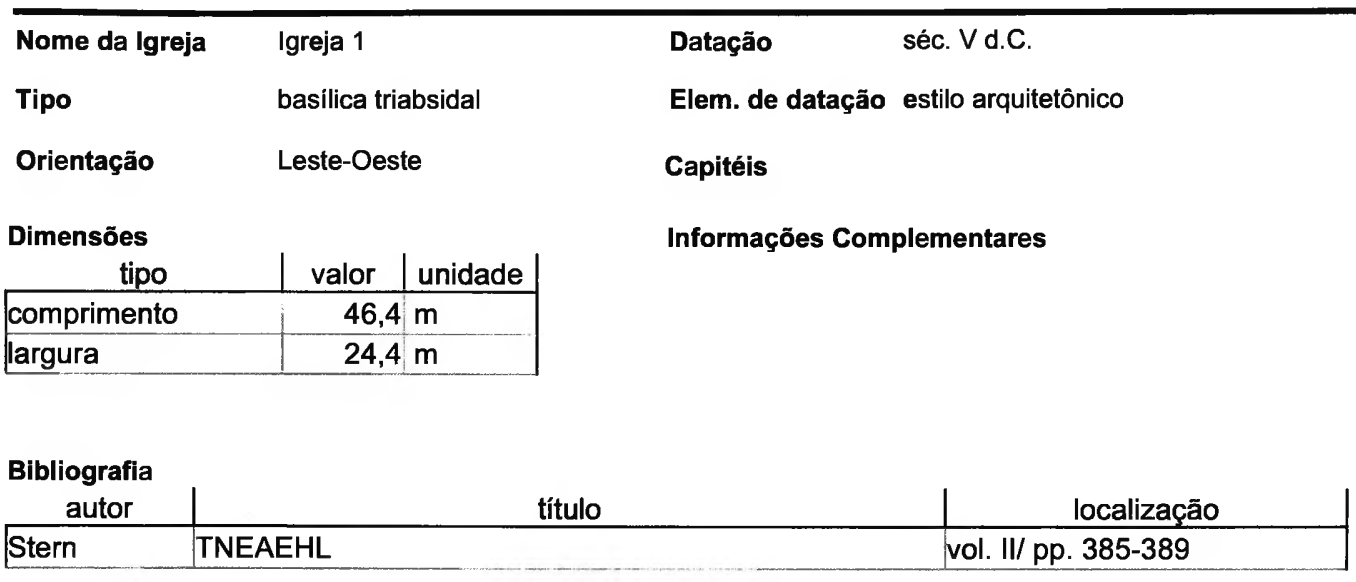

\section{Arquivo}

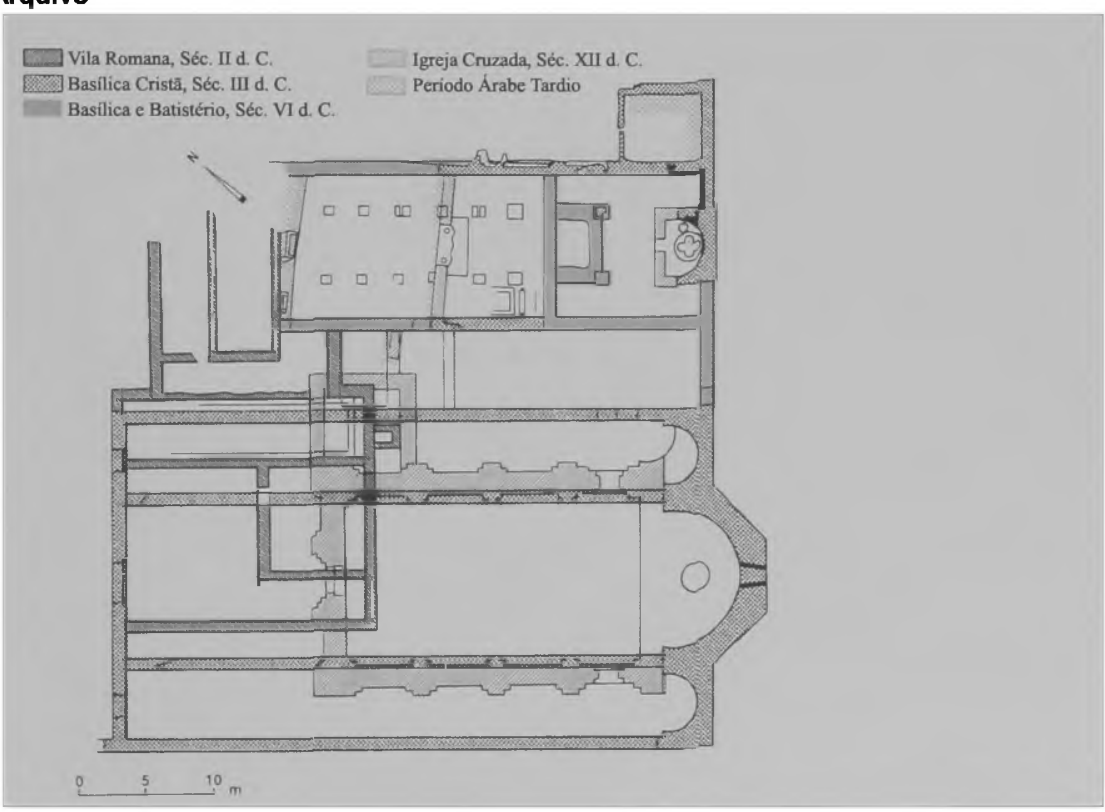

Planta da igreja conforme a configuração proposta pelos escavadores.

Emmaus_02.jpg 


\begin{tabular}{|c|c|c|}
\hline Nome da Igreja & Igreja 2 & fim do séc. V/ séc. VI d.C. \\
\hline Tipo & basílica monoabsidal & Elem. de datação \\
\hline Orientação & & Capitéis \\
\hline Dimensões & & Informações Complementares \\
\hline tipo & \begin{tabular}{l|l} 
valor & unidade \\
\end{tabular} & \multirow{3}{*}{$\begin{array}{l}\text { A igreja tem uma abside retangular. O batistério } \\
\text { localizava-se atrás do altar e tinha uma pia batismal de } \\
\text { pedra em forma de trevo. }\end{array}$} \\
\hline comprimento & \begin{tabular}{l|l|}
18 & $m$ \\
\end{tabular} & \\
\hline largura & $10 \mathrm{~m}$ & \\
\hline
\end{tabular}

\section{Bibliografia}

\begin{tabular}{|l|lc|}
$\begin{array}{c}\text { Bibliografia } \\
\text { autor }\end{array}$ & título & localização \\
\hline Stern & TNEAEHL & vol. II/ pp. 385-389 \\
\hline
\end{tabular}


Local 'Erav, Horvat

\begin{tabular}{|c|c|c|}
\hline Nome da Igreja & Igreja Oeste & século VI d.C. \\
\hline Tipo & basílica triabsidal & Elem. de datação \\
\hline Orientação & Leste-Oeste & Capitéis \\
\hline $\begin{array}{r}\text { Dimensões } \\
\text { tipo }\end{array}$ & valor $\mid$ unidade & Informações Complementares \\
\hline comprimento & $17,9 \mathrm{~m}$ & \\
\hline largura & $14,1 \mathrm{~m}$ & \\
\hline $\begin{array}{c}\text { Bibliografia } \\
\text { autor }\end{array}$ & título & localização \\
\hline Stern & $\overline{\mathrm{AEHL}}$ & vol. II/ p. 422 \\
\hline
\end{tabular}

Arquivo

Ficha XIX

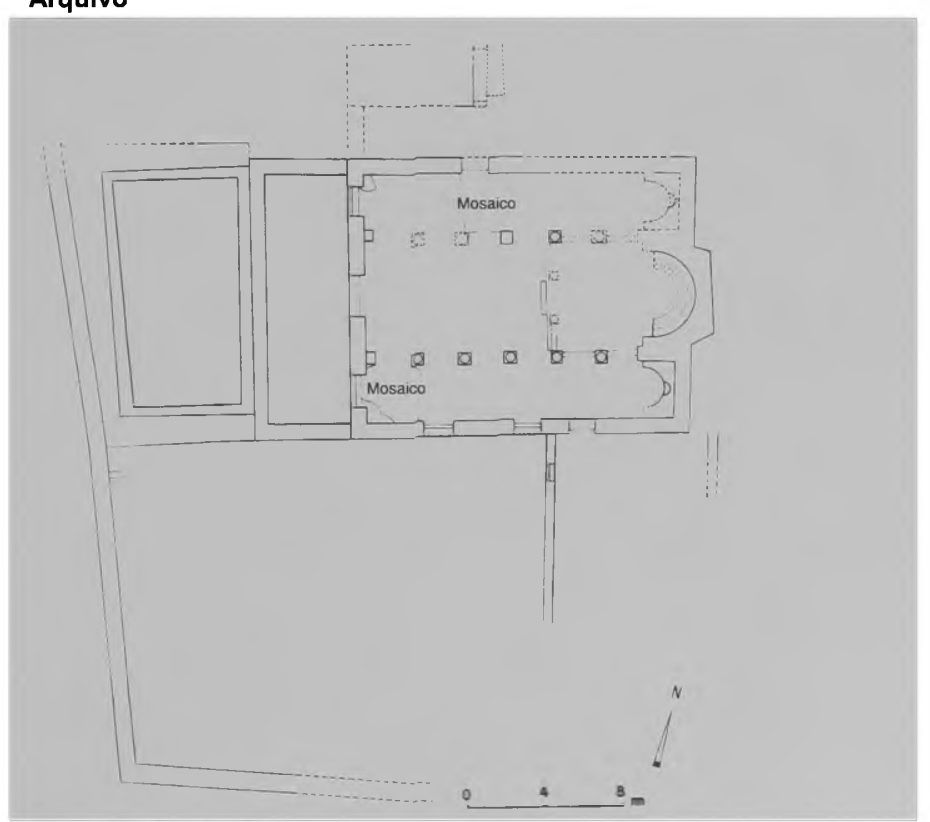

Planta da Igreja Oeste

EravHorvat_01.jpg 


\begin{tabular}{|c|c|c|}
\hline Nome da Igreja & Igreja Leste & séc. VI d.C. \\
\hline Tipo & basílica monoabsidal & Elem. de datação \\
\hline Orientação & & Capitéis \\
\hline Dimensões & & Informaçōes Complementares \\
\hline tipo & valor $\mid$ unidade & \multirow{3}{*}{$\begin{array}{l}\text { A abside central é circular e ladeada por duas salas } \\
\text { quadradas. }\end{array}$} \\
\hline comprimento & $20 \mathrm{~m}$ & \\
\hline |largura & $16 \mathrm{~m}$ & \\
\hline
\end{tabular}

\section{Bibliografia}

\begin{tabular}{|l|l|l|}
$\begin{array}{c}\text { autor } \\
\text { Stern }\end{array}$ & título & localização \\
\hline
\end{tabular}


Local

'Evron

\begin{tabular}{|c|c|}
\hline \multicolumn{2}{|c|}{ Nome da Igreja } \\
\hline Tipo & basilica triabsidal \\
\hline Orientação & Leste-Oeste \\
\hline Dimensões & \\
\hline tipo & valor unidade \\
\hline comprimento & $14,5 \mathrm{~m}$ \\
\hline largura & $10,6 \mathrm{~m}$ \\
\hline
\end{tabular}

Datação

séc. V d.C.

Elem. de datação inscrições no piso

\section{Capitéis}

\section{Informações Complementares}

Anexo ao lado norte encontram-se duas salas: o batistério e o diaconicon.

\section{Bibliografia}

\begin{tabular}{|l|l|l|}
\multicolumn{1}{c}{$\begin{array}{l}\text { autor } \\
\text { Stern }\end{array}$} & título & localização \\
\hline
\end{tabular}

\section{Arquivo}

Ficha XXI

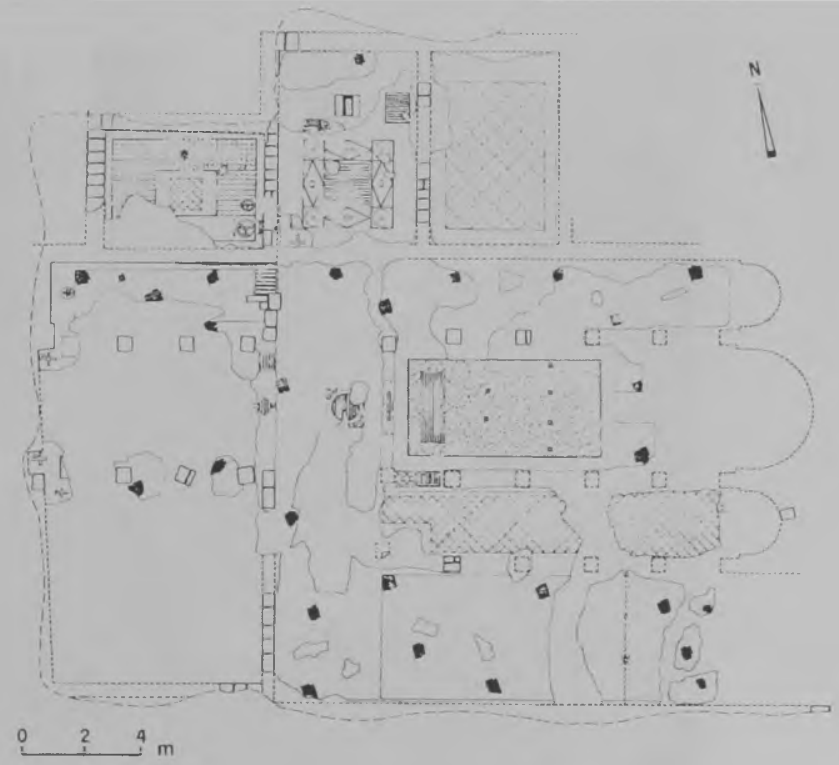

Planta da igreja

Evron_01.jpg 
Local Gerarit, Horvat

Nome da Igreja

Tipo

basílica

Orientação

Dimensões séc. VI d.C.

\section{Elem. de datação}

\section{Capitéis}

Informações Complementares

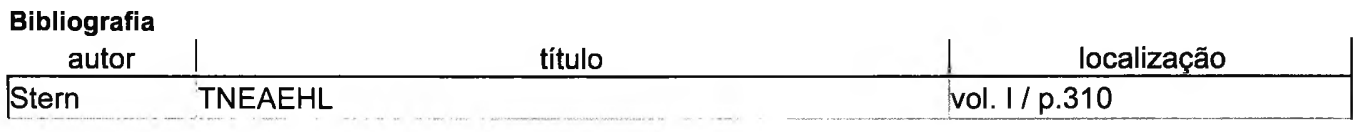




\section{Local Gerasa}

\begin{tabular}{llll}
\hline Nome da Igreja & $\begin{array}{l}\text { Igreja de São Pedro e São } \\
\text { Paulo }\end{array}$ & Datação & cerca de 540 d.C.
\end{tabular}

Tipo basilica triabsidal

Orientação

Dimensões

\section{Elem. de datação}

Capitéis

Informações Complementares

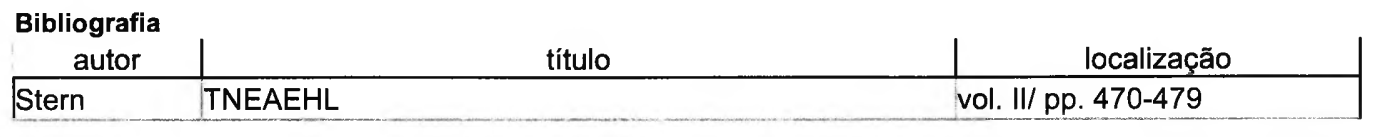

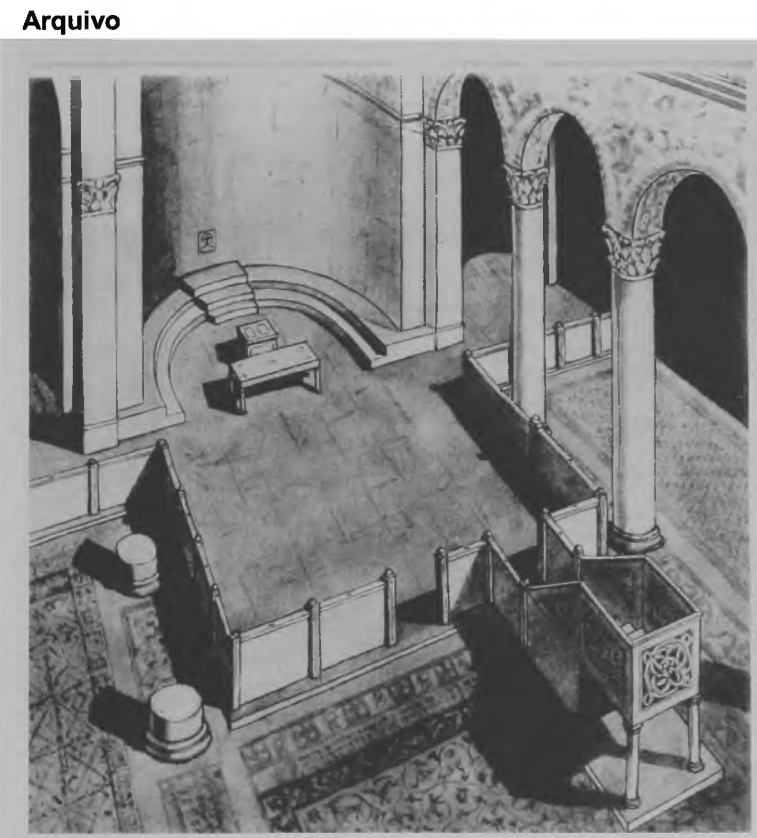

Igreja de São Pedro e São Paulo: reconstituição da basílica 
Formas Arquitetônicas Clássicas em Edifícios Religiosos do Período Bizantino.

Revista do Museu de Arqueologia e Etnologia, São Paulo, Suplemento 5, 2008.

Nome da Igreja Igreja de Procopius

Tipo basilica triabsidal

Orientação

Dimensões

\section{Bibliografia}

\begin{tabular}{|c|c|c|}
$\begin{array}{c}\text { autor } \\
\text { Stern }\end{array}$ & título & localização \\
\hline
\end{tabular}

\section{Datação cerca de 526-527 d.C}

Elem. de datação

\section{Capitéis}

Informaçōes Complementares

As três absides são internas. 


\begin{tabular}{|c|c|c|}
\hline Nome da Igreja & Catedral & cerca de 400 d.C. \\
\hline Tipo & basilica monoabsidal & Elem. de datação \\
\hline Orientação & & Capitéis \\
\hline \multirow[t]{2}{*}{ Dimensões } & & Informações Complementares \\
\hline & & $\begin{array}{l}\text { A basilica tem uma abside poligonal interna. } \\
\text { É a igreja mais antiga conhecida em Gerasa. }\end{array}$ \\
\hline \multicolumn{3}{|l|}{ Bibliografia } \\
\hline autor & título & localização \\
\hline Stern & TNEAEHL & vol. II/ pp. 474-476 \\
\hline
\end{tabular}

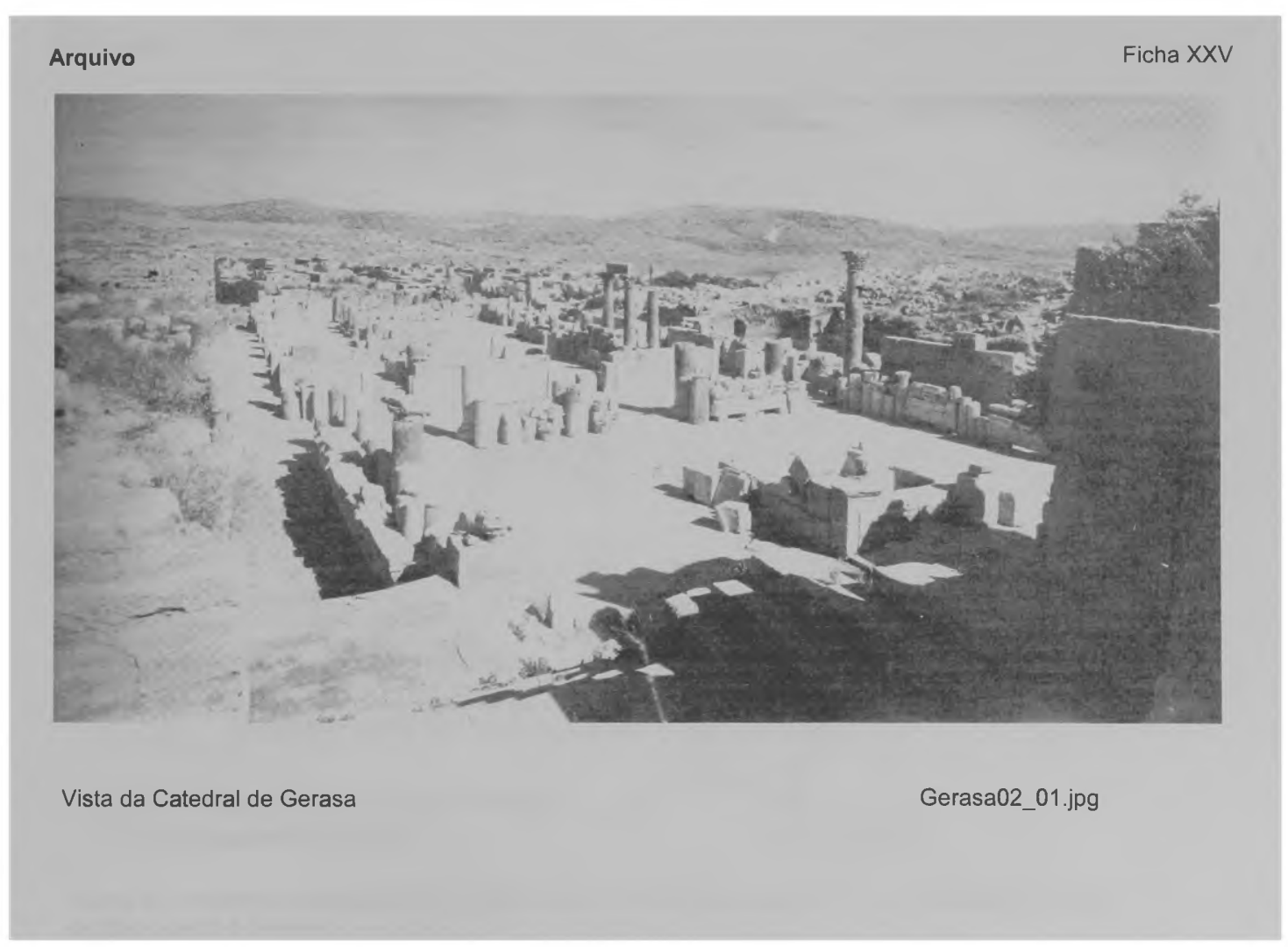




\begin{tabular}{lll}
\hline $\begin{array}{l}\text { Nome da Igreja } \\
\text { Tipo }\end{array}$ & $\begin{array}{l}\text { Igreja de São Teodoro } \\
\text { basilica }\end{array}$ & $\begin{array}{l}\text { Datação } \\
\text { Elem. de datação }\end{array}$ \\
Orientação & Capitéis \\
Dimensões & Informações Complementares \\
& $\begin{array}{l}\text { A nave dessa igreja é cercada por vários anexos: uma } \\
\text { capela, um batistério e outras salas. }\end{array}$
\end{tabular}

\begin{tabular}{|c|c|c|}
\hline $\begin{array}{c}\text { Bibliografia } \\
\text { autor }\end{array}$ & título & localização \\
\hline Stern & TNEAEHL & vol. II/ p. 476 \\
\hline
\end{tabular}




\begin{tabular}{|c|c|c|}
\hline Nome da Igreja & $\begin{array}{l}\text { Igrejas de São João } \\
\text { Batista, São Jorge, São } \\
\text { Cosme e Damião }\end{array}$ & $529-533$ d.C. \\
\hline Tipo & basílica monoabsidal & Elem. de datação \\
\hline Orientação & Leste-Oeste & Capitéis \\
\hline Dimensões & & Informações Complementares \\
\hline tipo & \begin{tabular}{l|l} 
valor & unidade \\
\end{tabular} & \multirow{3}{*}{$\begin{array}{l}\text { Constitui um complexo de igrejas, sendo que a igreja de } \\
\text { São Cosme e Damião, ao centro, tem planta circular. } \\
\text { A largura indicada corresponde à largura das igrejas de } \\
\text { São João Batista e São Jorge, que são as basílicas } \\
\text { monoabsidais das extremidades do complexo. }\end{array}$} \\
\hline comprimento & $29,5 \mathrm{~m}$ & \\
\hline |largura & $14 \mathrm{~m}$ & \\
\hline
\end{tabular}

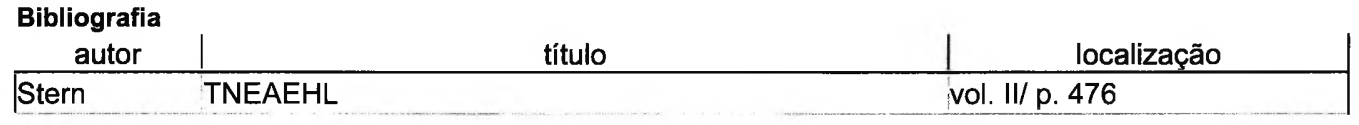

\section{Arquivo}

Ficha XXVII

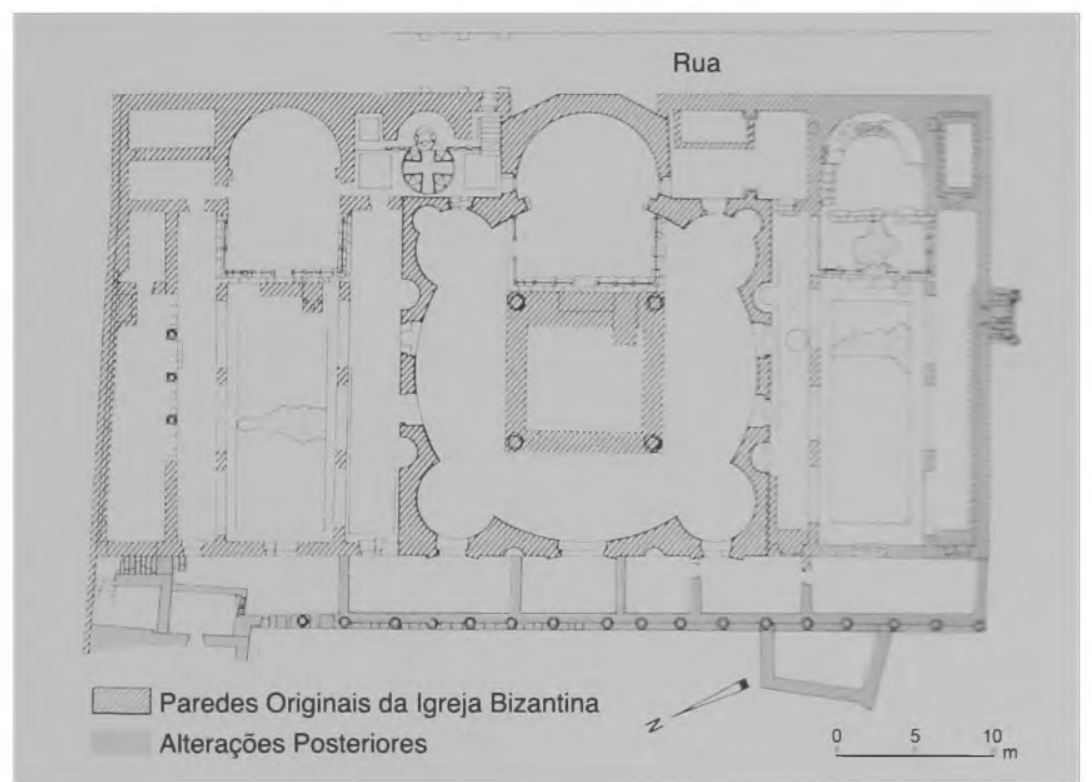

Planta do complexo de igrejas de São João Batista, São Jorge (ao sul) e

Gerasa01_01.jpg de São Cosme e Damião. 


\begin{tabular}{|c|c|c|}
\hline Nome da Igreja & Igreja Sinagoga & 530-531 d.C. \\
\hline Tipo & basilica monoabsidal & Elem. de datação \\
\hline Orientação & & Capitéis \\
\hline
\end{tabular}

Dimensões

\section{Informações Complementares}

Dentro da igreja foram encontrados restos de uma sinagoga.

Duas fileiras de 4 colunas dividem a nave central das naves laterais.

\begin{tabular}{c|c|c|}
$\begin{array}{c}\text { Bibliografia } \\
\text { autor }\end{array}$ & título & localização \\
\hline Stern & TNEAEHL & vol. II/ pp. 477-478 \\
\hline
\end{tabular}

\section{Arquivo}




\begin{tabular}{|c|c|c|}
\hline Nome da Igreja & $\begin{array}{l}\text { Igreja dos profetas, } \\
\text { apóstolos e mártires }\end{array}$ & $464-465$ d.C. \\
\hline Tipo & cruciforme & Elem. de datação \\
\hline Orientação & & Capitéis \\
\hline \multirow[t]{2}{*}{ Dimensões } & & Informaçōes Complementares \\
\hline & & $\begin{array}{l}\text { A planta cruciforme não é usual para a época em que a } \\
\text { igreja foi construída. Cada um dos braços da igreja tem } \\
\text { uma nave central e duas naves laterais. }\end{array}$ \\
\hline \multicolumn{3}{|l|}{ Bibliografia } \\
\hline autor & título & localização \\
\hline Stern & $\mathrm{AEHL}$ & vol. II/ p. 478 \\
\hline
\end{tabular}




\section{Local Gerizim, Mount}

\begin{tabular}{|c|c|}
\hline Nome da Igreja & $\begin{array}{l}\text { Igreja de Maria, mãe d } \\
\text { Jesus }\end{array}$ \\
\hline Tipo & octogonal \\
\hline Orientação & Leste-Oeste \\
\hline \multicolumn{2}{|l|}{ Dimensões } \\
\hline tipo & valor | unidade \\
\hline comprimento & $37,4 \mathrm{~m}$ \\
\hline largura & $30 \mathrm{~m}$ \\
\hline
\end{tabular}

Datação

484 d.C.

Elem. de datação

\section{Capitéis}

\section{Informações Complementares}

A igreja está inscrita dentro de um precinto circundado por muros e torres, medindo $100 \times 83 \mathrm{~m}$.

Essa igreja foi construida pelo imperador Zeno, durante um embate entre cristãos e samaritanos.

\begin{tabular}{|l|l|l|}
$\begin{array}{c}\text { Bibliografia } \\
\text { autor }\end{array}$ & titulo & \multicolumn{1}{c|}{ localização } \\
\hline Stern & TNEAEHL & vol. II/ pp. 490-492 \\
\hline Tsafrir & ACR & pp. 83-89 \\
\hline
\end{tabular}

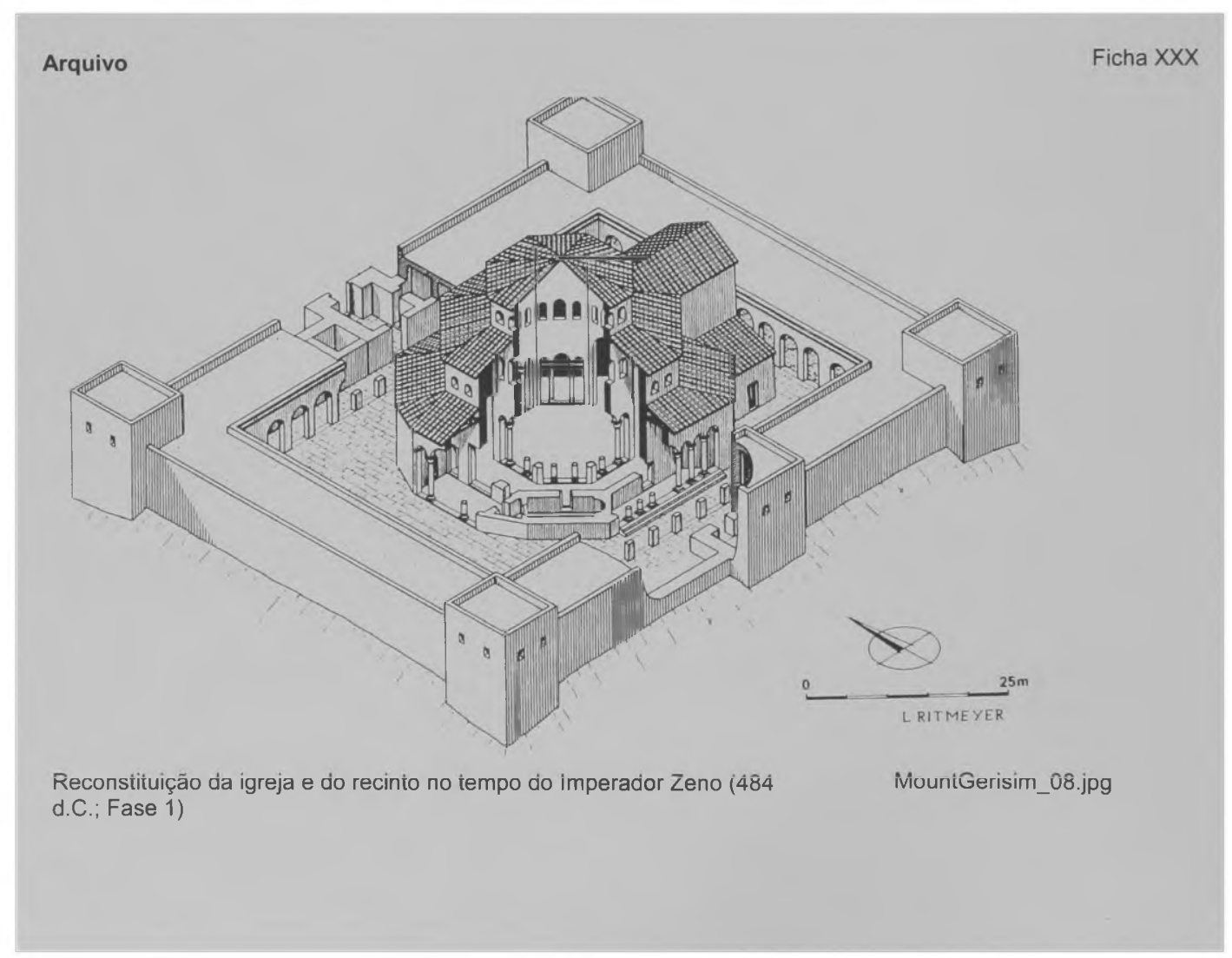




\section{Local Giv'it Horvat}

\section{Nome da Igreja}

Tipo

Orientação

basílica monoabsidal

Leste-Oeste

Dimensōes

\begin{tabular}{|l|r|l|}
\multicolumn{1}{c|}{ tipo } & valor & unidade \\
\hline Comprimento & 14,7 & $\mathrm{~m}$ \\
\hline largura & $10,5 \mathrm{~m}$ \\
\hline
\end{tabular}

Datação século VI d.C.

Elem. de datação

Capitéis

\section{Informaçōes Complementares}

\begin{tabular}{|llc|c|}
$\begin{array}{c}\text { Bibliografia } \\
\text { autor }\end{array}$ & titulo & localização \\
\hline Stern & TNEAEHL & & vol. II/ pp. 524-525 \\
\hline
\end{tabular}

Arquivo

Ficha $X X X I$

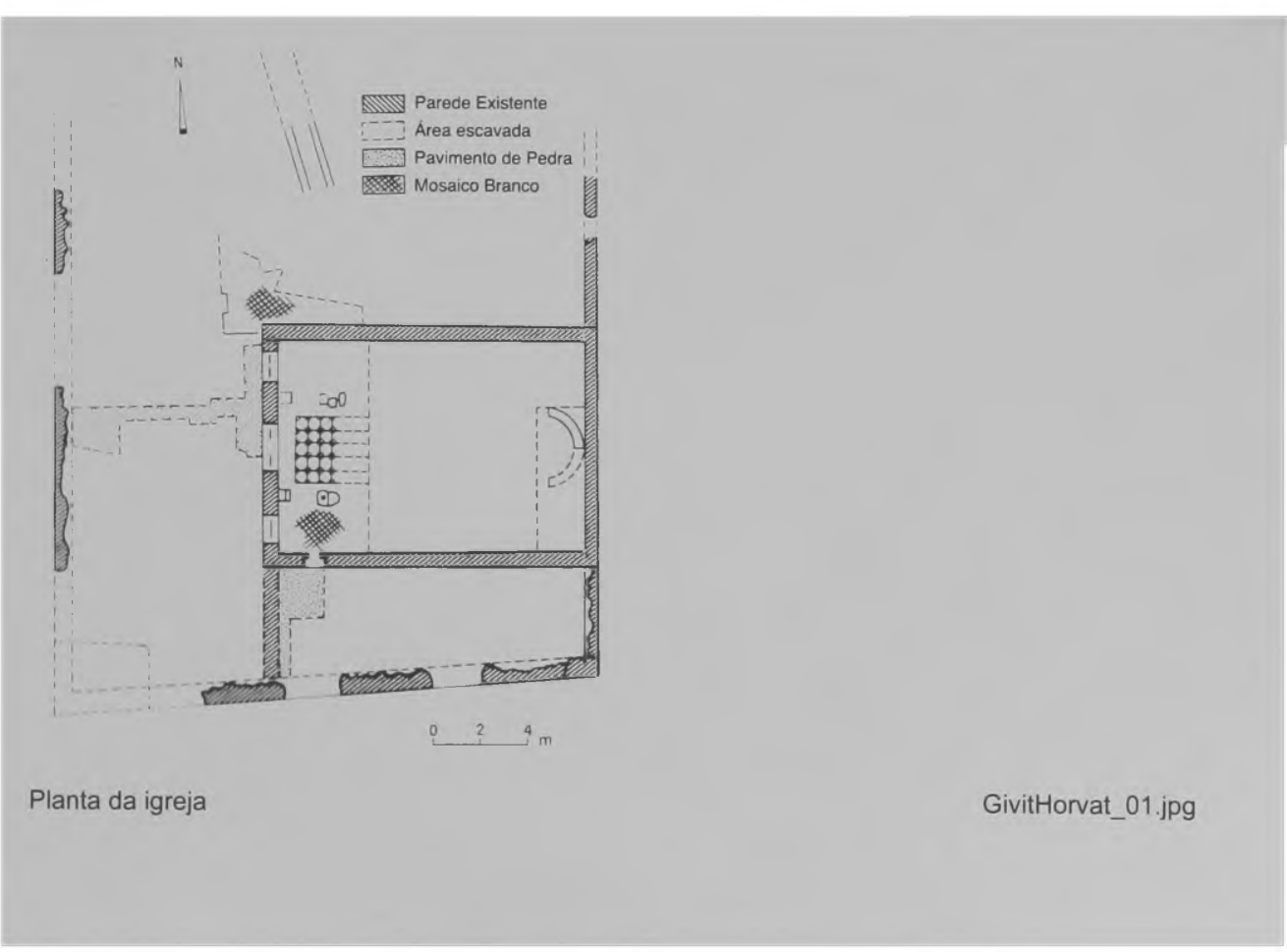




\section{Local Hadat, Horvat}

Nome da Igreja

Tipo

basilica monoabsidal

Orientação

Dimensões

\begin{tabular}{|c|c|c|}
\hline tipo & valor & unidade \\
\hline comprimento & & \\
\hline
\end{tabular}

\section{Datação}

séc. V d.C.

Elem. de datação

\section{Capitéis}

\section{Informações Complementares}

A abside da igreja é externa. A nave central é separada das naves laterais por duas fileiras com 3 colunas.

\begin{tabular}{|c|c|c|}
$\begin{array}{c}\text { Bibliografia } \\
\text { autor }\end{array}$ & título & \multicolumn{1}{c|}{ localização } \\
\hline Stern & TNEAEHL & vol. I / p. 310 \\
\hline
\end{tabular}




\section{Local Hanita}

Nome da Igreja Datação séc. VI d.C.

Tipo basilica monoabsidal

Orientação

Dimensōes tipo valor unidade comprimento largura $17 \mathrm{~m}$ $14 \mathrm{~m}$
Elem. de datação

\section{Capitéis}

\section{Informações Complementares}

A abside da igreja é externa. A nave central é separada das naves laterais por duas fileiras com 4 colunas.

\begin{tabular}{|l|l|l|}
$\begin{array}{c}\text { Bibliografia } \\
\text { autor }\end{array}$ & título & localização \\
\hline Stern & TNEAEHL & vol. I/p. 310 \\
\hline
\end{tabular}

Arquivo

Ficha $X X X I I I$ 
Local Haspin

\begin{tabular}{|c|c|}
\hline Nome da Igreja & $\begin{array}{l}\text { Igreja Oeste (Igreja de } \\
\text { Georgius) }\end{array}$ \\
\hline Tipo & basilica triabsidal \\
\hline Orientação & Leste-Oeste \\
\hline \multicolumn{2}{|l|}{ Dimensões } \\
\hline tipo & valor | unidade \\
\hline comprimento & $20,5 \mathrm{~m}$ \\
\hline largura & $14,2 \mathrm{~m}$ \\
\hline
\end{tabular}

Datação

século VI d.C.

\section{Elem. de datação}

\section{Capitéis}

\section{Informações Complementares}

Provavelmente essa igreja faz parte de um complexo maior, como um monastério.

\begin{tabular}{|c|c|c|}
\hline $\begin{array}{c}\text { Bibliografia } \\
\text { autor }\end{array}$ & título & localização \\
\hline Stern & TNEAEHL & vol. II/ pp. 586-589 \\
\hline
\end{tabular}

\section{Arquivo}

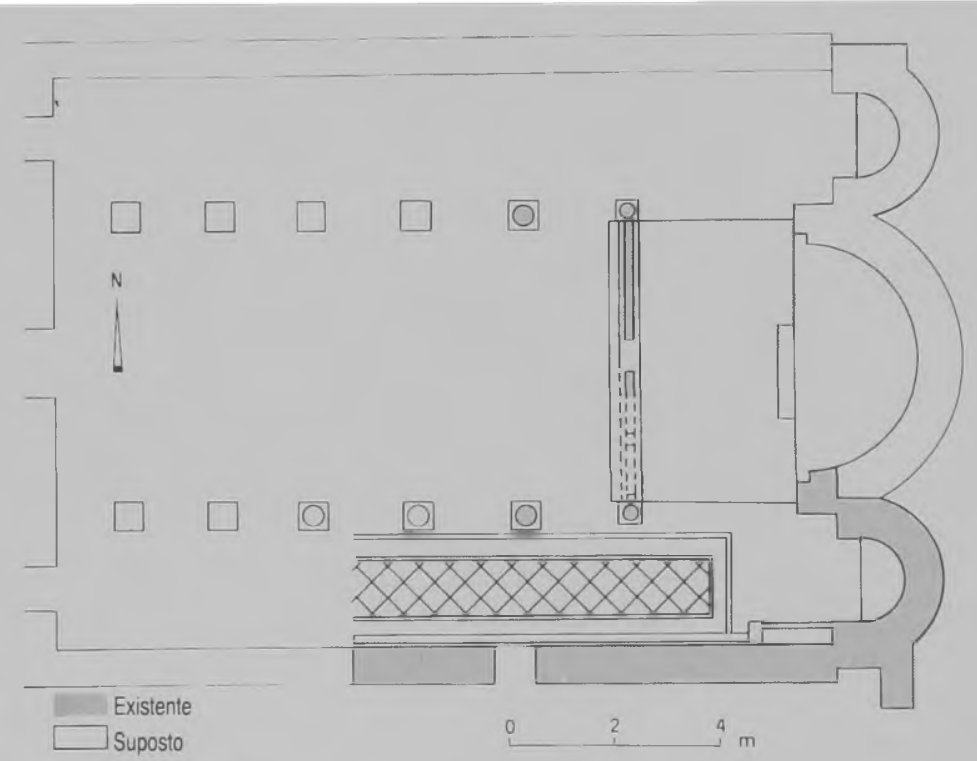

Planta da Igreja Oeste 


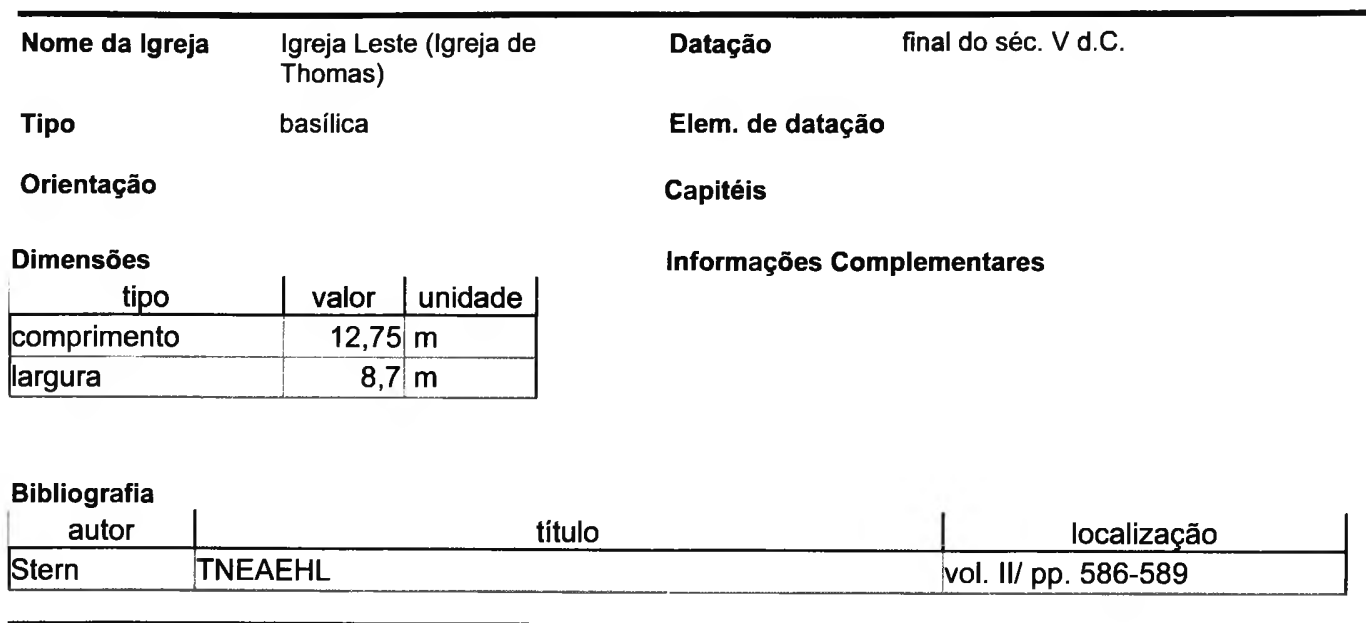

Arquivo

Ficha $X X X V$ 


\section{Local Hazor-Ashdod}

\section{Nome da Igreja}

Tipo

basilica monoabsidal

\section{Orientação}

\section{Dimensões}

\begin{tabular}{|l|r|l|}
\multicolumn{1}{c|}{ tipo } & valor & unidade \\
\hline Comprimento & 12,5 & $\mathrm{~m}$ \\
\hline largura & 10,5 & $\mathrm{~m}$ \\
\hline
\end{tabular}

Datação séc. VI d.C.

Elem. de datação inscrição em Grego no mosaico

\section{Capitéis}

\section{Informações Complementares}

A abside dessa igreja provavelmente era externa. A nave central foi separada das naves laterais por duas fileiras de 3 colunas.

A igreja possuía um nártex com $3 \mathrm{~m}$ de largura.

\begin{tabular}{|l|l|l|}
$\begin{array}{l}\text { Bibliografia } \\
\text { autor }\end{array}$ & título & \multicolumn{1}{c|}{ localização } \\
\hline Stern & TNEAEHL & vol. I/ pp. 310-311 \\
\hline
\end{tabular}

Arquivo

Ficha $X X X V I$ 


\section{Local Heptapegon}

Nome da Igreja

Tipo

Orientação

basilica com transepto

Leste-Oeste

Dimensões

\begin{tabular}{|l|r|l|}
\multicolumn{1}{|c|}{ tipo } & valor & unidade \\
\hline Comprimento & 25 & $\mathrm{~m}$ \\
\hline largura & 19 & $\mathrm{~m}$ \\
\hline
\end{tabular}

Datação

metade do séc. $V$ d.C.

Elem. de datação

\section{Capitéis}

\section{Informações Complementares}

Havia uma capela, construida no local no séc. IV.

A igreja provavelmente foi destruida no séc. VII, durante a invasão persa ou árabe.

\begin{tabular}{|c|c|c|}
\hline $\begin{array}{c}\text { Bibliografia } \\
\text { autor }\end{array}$ & título & localização \\
\hline Stern & TNEAEHL & vol. II/ pp. 614-616 \\
\hline
\end{tabular}

\section{Arquivo}
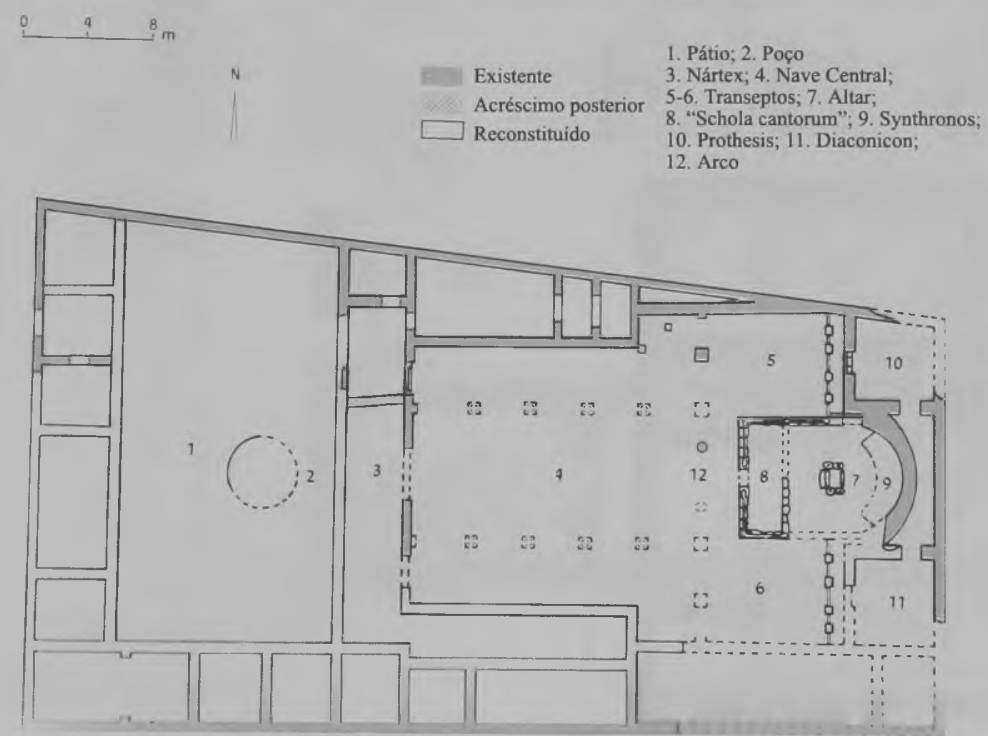

Planta da igreja 


\section{Local Herodium}

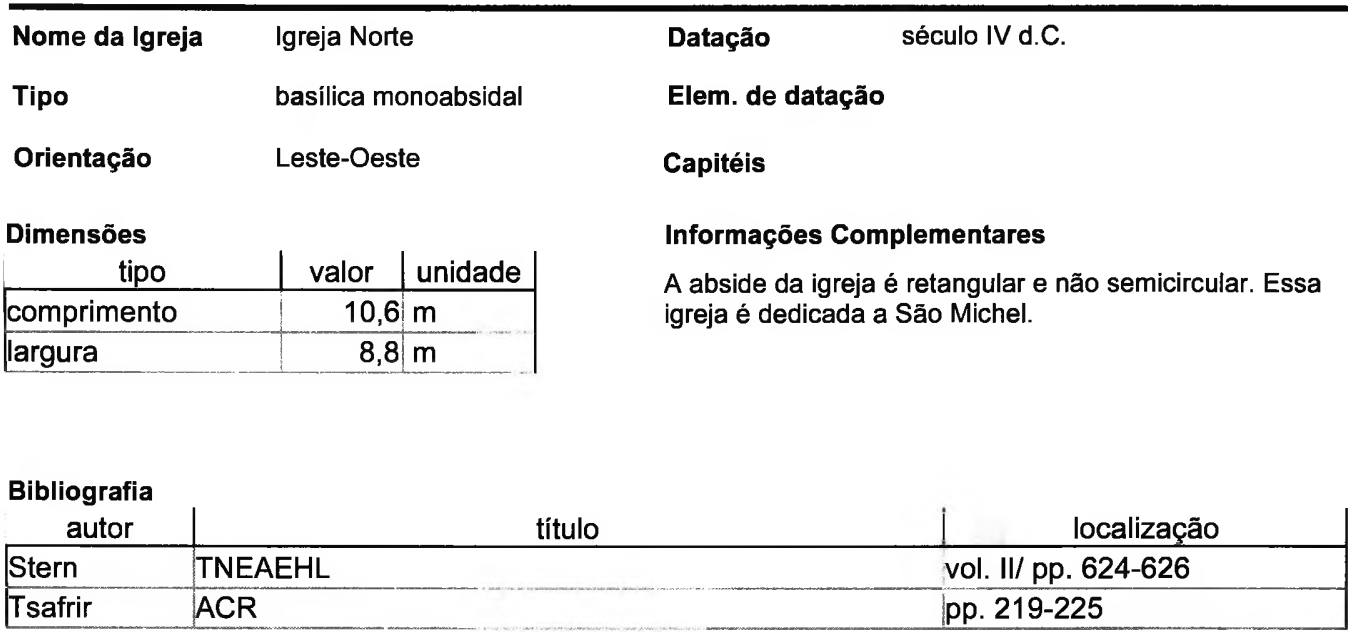

\section{Arquivo}

Ficha XXXVIII
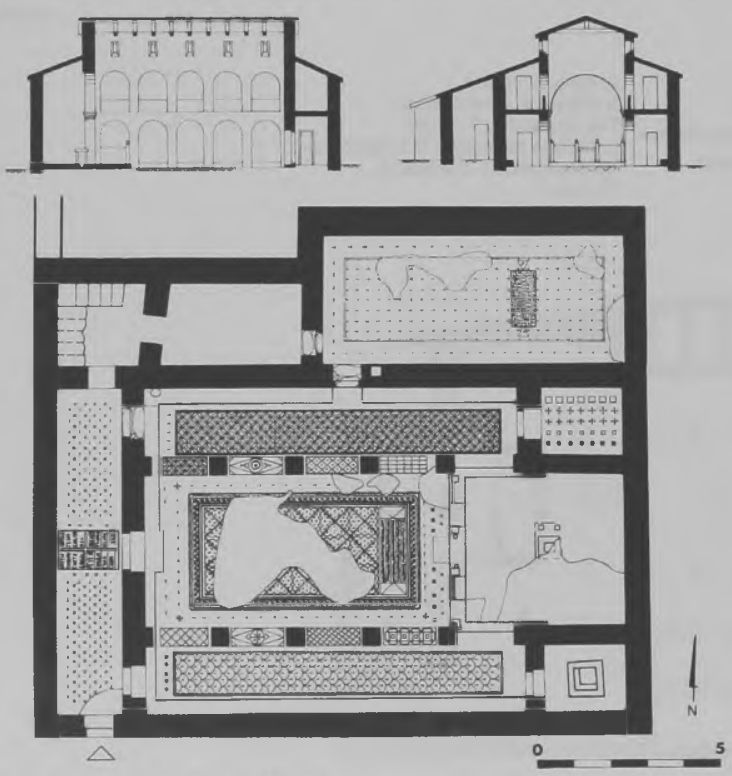

Planta e cortes da Igreja Norte 


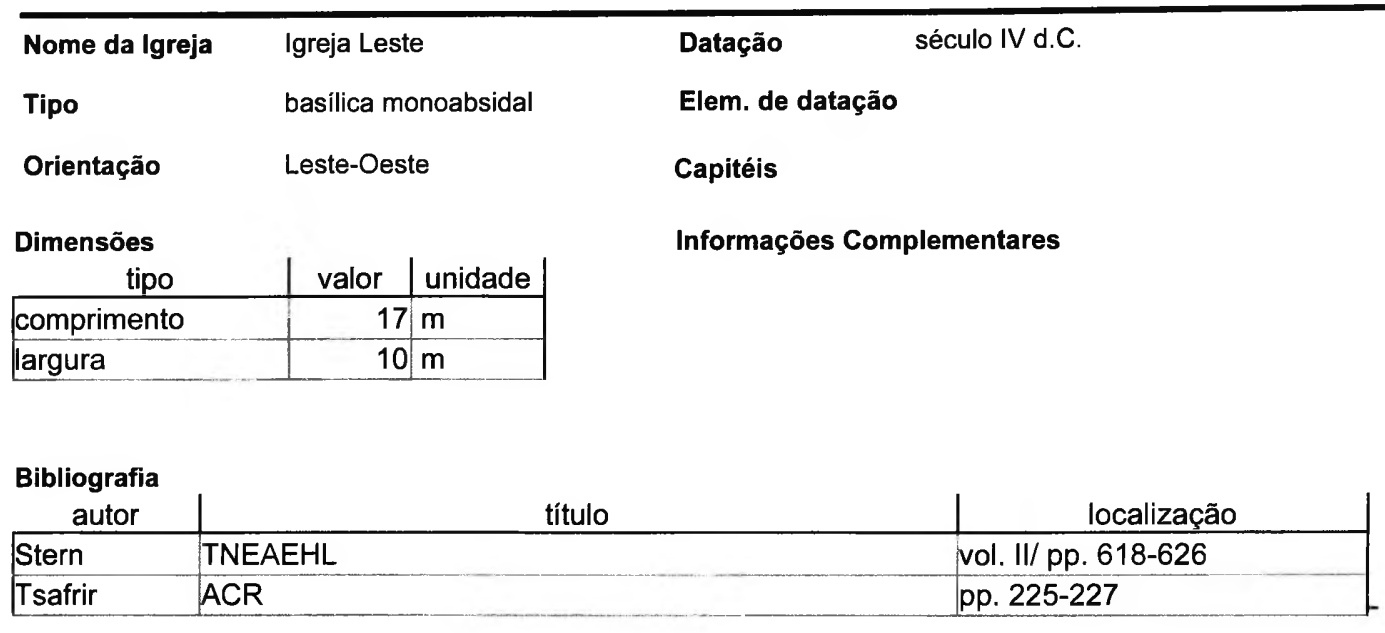

Arquivo

Ficha XXXIX

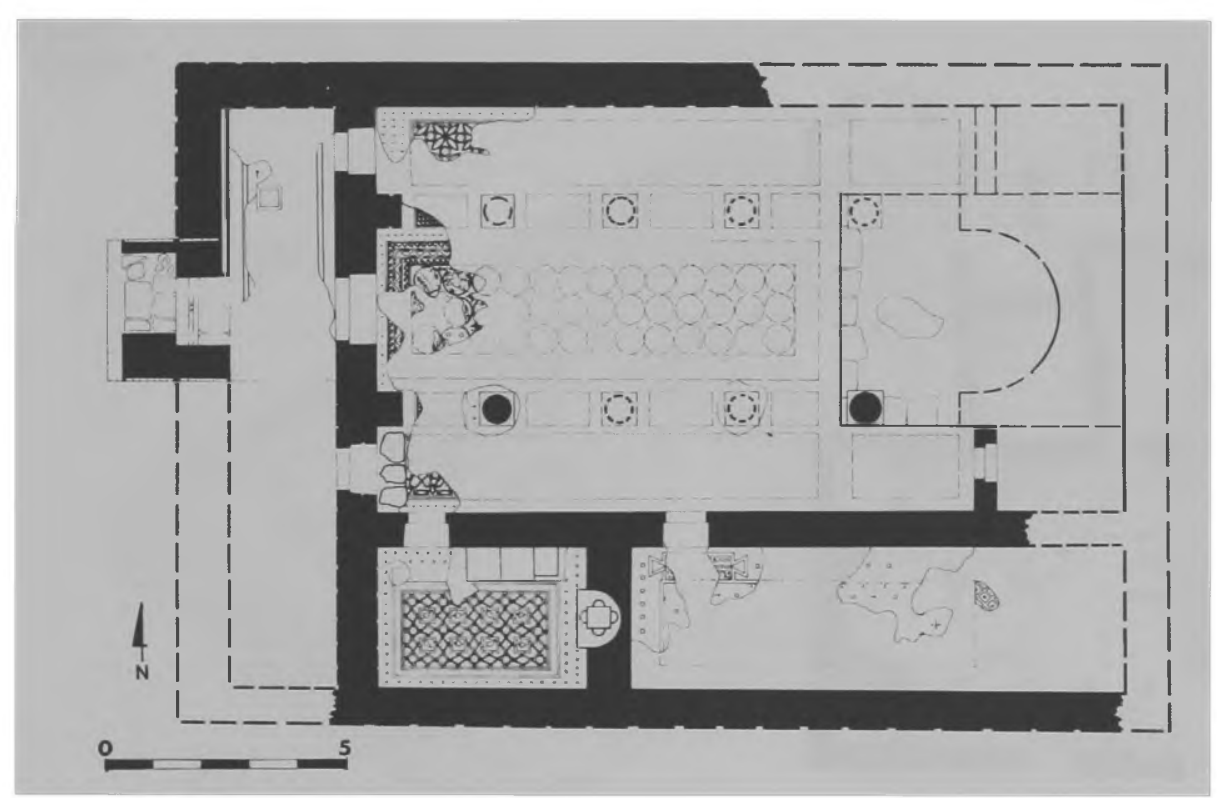

Planta da Igreja Leste

Herodium03_02.jpg 


\begin{tabular}{|c|c|c|}
\hline Nome da Igreja & Igreja Central & século IV d.C. \\
\hline Tipo & basilica monoabsidal & Elem. de datação \\
\hline Orientação & Leste-Oeste & Capitéis \\
\hline Dimensões & & Informaçōes Complementares \\
\hline tipo & valor $\quad$ unidade & \multirow{3}{*}{$\begin{array}{l}\text { No lugar de um nártex para entrada a oeste, o acesso à } \\
\text { igreja se faz por um corredor estreito com acesso pelo } \\
\text { norte. }\end{array}$} \\
\hline comprimento & $11,5 \mathrm{~m}$ & \\
\hline largura & $10,5 \mathrm{~m}$ & \\
\hline
\end{tabular}

\section{Bibliografia}

\begin{tabular}{|l|l|l|}
$\begin{array}{l}\text { Bibliografia } \\
\text { autor }\end{array}$ & título & \multicolumn{1}{c|}{ localização } \\
\hline Stern & TNEAEHL & vol. II/ pp. 618-626 \\
\hline Tsafrir & ACR & pp. 227-232 \\
\hline
\end{tabular}

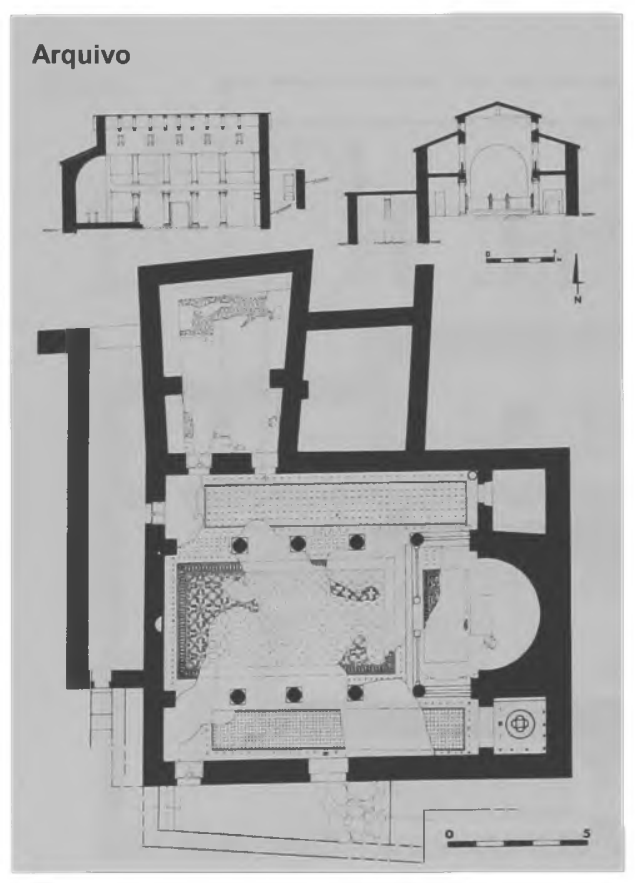

Planta e cortes da Igreja Central

Ficha XL 


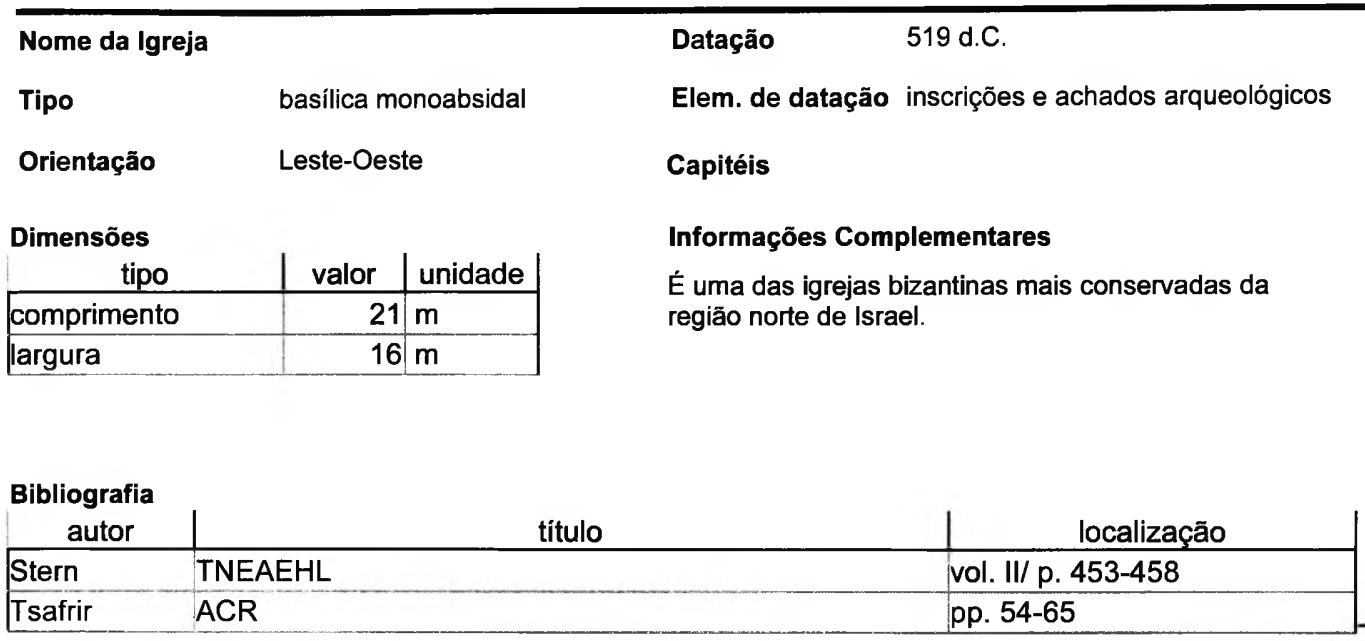

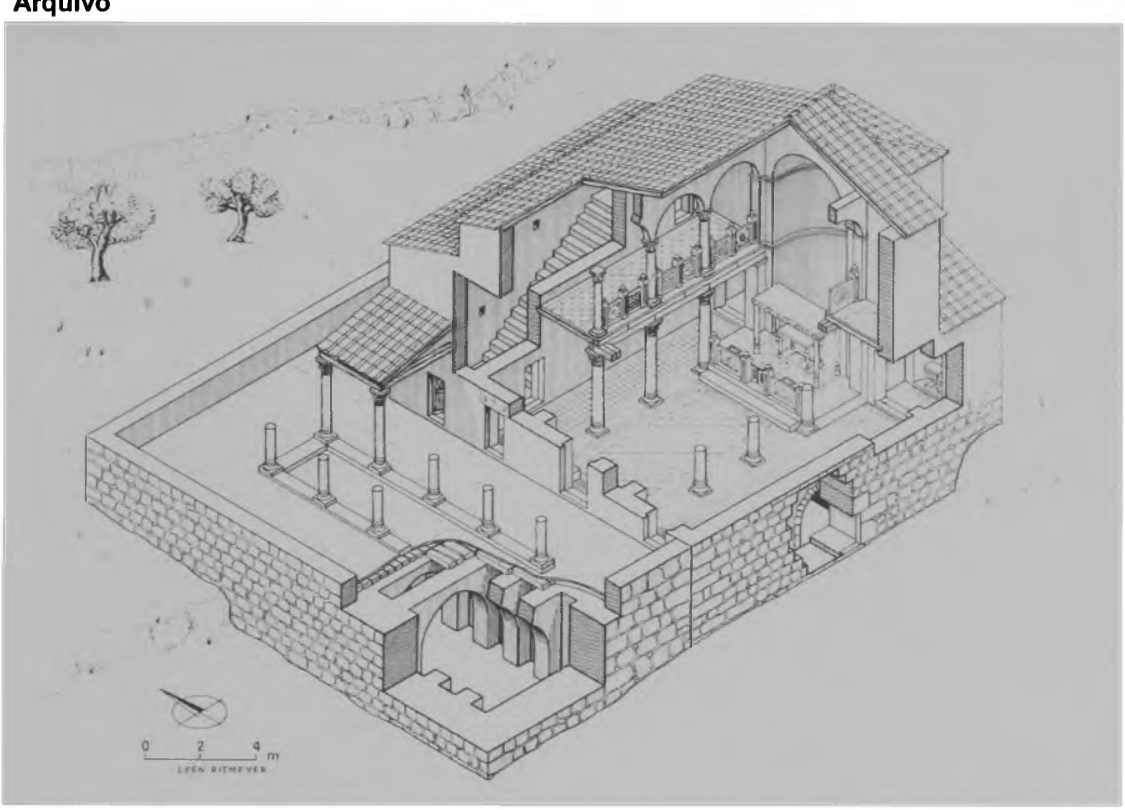




\section{Local Hippos}

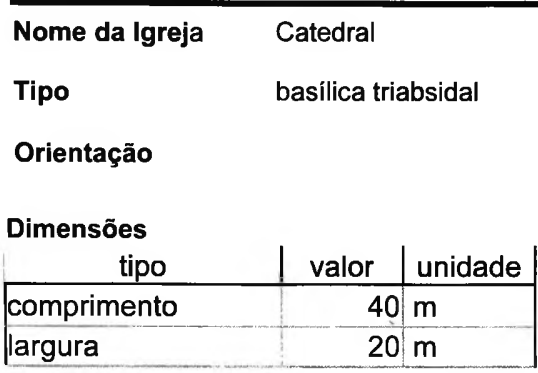

Datação

século IV d.C.

Elem. de datação

Capitéis corintios

\section{Informações Complementares}

As absides da igreja são inscritas. A nave central é separada das naves laterais por duas fileiras com 9 colunas.

\begin{tabular}{|l|l|l|}
$\begin{array}{c}\text { Bibliografia } \\
\text { autor }\end{array}$ & titulo & localização \\
\hline Stern & TNEAEHL & vol. II/ pp. 634-636 \\
\hline
\end{tabular}


Hubeila, Khirbet EI-

\begin{tabular}{|c|c|c|}
\hline \multicolumn{3}{|c|}{ Nome da Igreja } \\
\hline Tipo & \multicolumn{2}{|c|}{ basílica monoabsidal } \\
\hline \multicolumn{3}{|l|}{ Orientação } \\
\hline Dimensões & & \\
\hline tipo & valor & unidade \\
\hline Comprimento & & $m$ \\
\hline largura & 12,5 & $\mathrm{~m}$ \\
\hline
\end{tabular}

Datação

Elem. de datação

\section{Capitéis}

\section{Informações Complementares}

A abside dessa basílica é externa. Duas fileiras de 4 colunas separam a nave central das duas naves laterais.

\section{Bibliografia}

\begin{tabular}{|l|l|l|}
\multicolumn{1}{c|}{$\begin{array}{c}\text { autor } \\
\text { Stern }\end{array}$} & título & \multicolumn{1}{c|}{ localização } \\
\hline
\end{tabular}




\section{Local}

\begin{tabular}{|c|c|c|}
\hline Nome da Igreja & \multirow{2}{*}{\multicolumn{2}{|c|}{$\begin{array}{l}\text { Igreja da Virgem Sant } \\
\text { basilica monoabsidal }\end{array}$}} \\
\hline Tipo & & \\
\hline \multicolumn{3}{|l|}{ Orientação } \\
\hline \multicolumn{3}{|l|}{ Dimensões } \\
\hline tipo & valor & unidade \\
\hline comprimento & & $m$ \\
\hline largura & & $m$ \\
\hline
\end{tabular}

\section{Datação séc. VI d.C.}

Elem. de datação

\section{Capitéis}

\section{Informações Complementares}

Essa igreja foi identificada como a igreja da virgem santa e, segundo o relato de Procopius, ela existia anteriormente e foi restaurada pelo imperador Justiniano.

\begin{tabular}{l|l|l|}
$\begin{array}{c}\text { Bibliografia } \\
\text { autor }\end{array}$ & titulo & localização \\
\hline Stern & TNEAEHL & vol. II/ pp. 696-697 \\
\hline
\end{tabular}

\section{Arquivo}
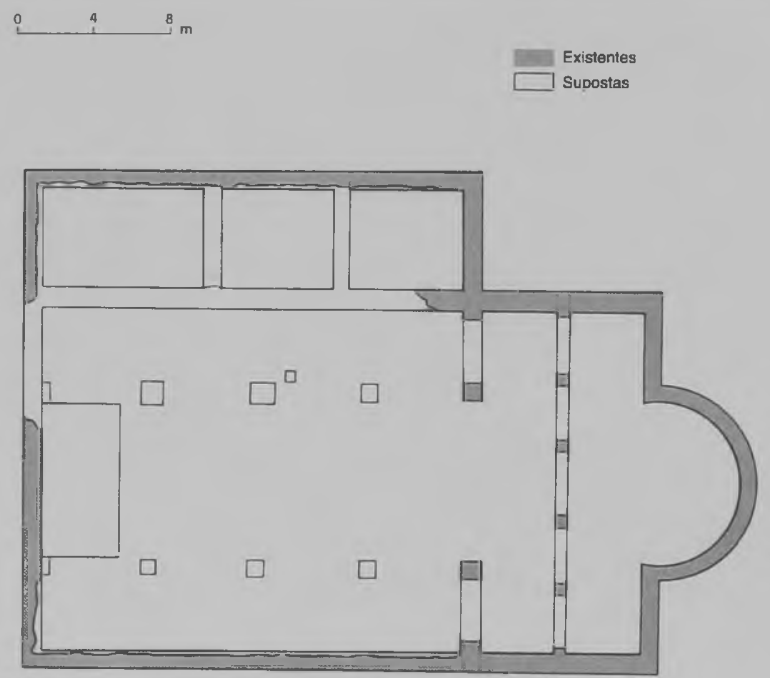

Planta da igreja 
Local Jerusalém

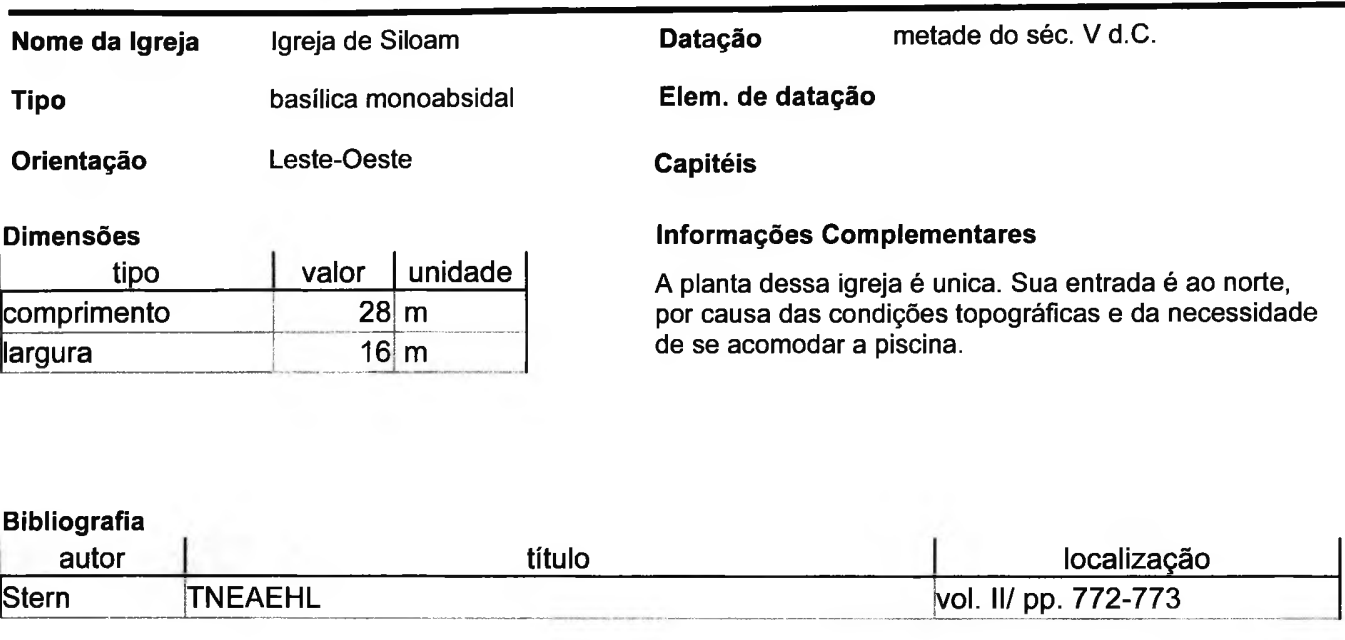

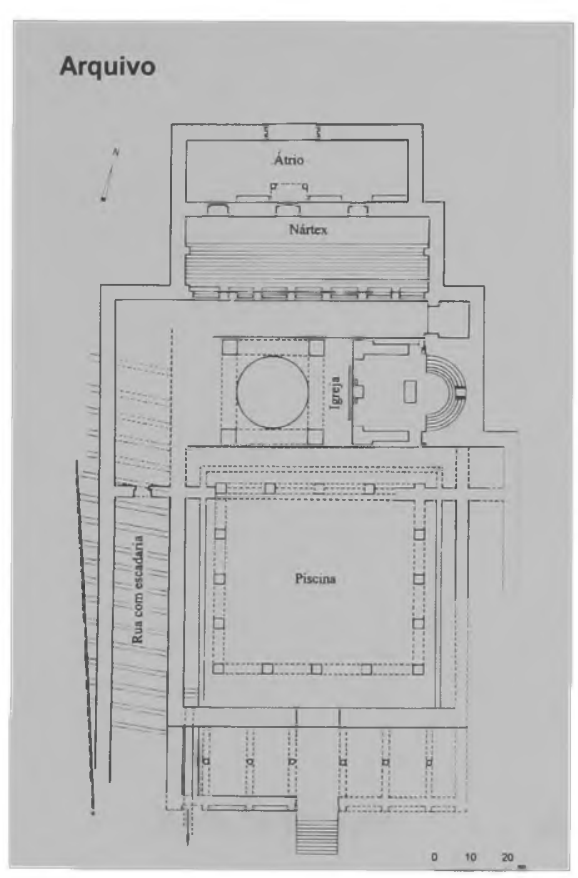

Planta da Igreja Siloam no Poço Siloam como era no periodo Bizantino Ficha XLV Jerusalem01_01.jpg 


\begin{tabular}{|c|c|c|}
\hline Nome da Igreja & Igreja "Nea" & Datação \\
\hline Tipo & basilica triabsidal & Elem. de datação \\
\hline Orientação & Leste-Oeste & Capitéis \\
\hline Dimensōes & & Informações Complementares \\
\hline tipo & valor unidade & \\
\hline comprimento & $115 \mathrm{~m}$ & \\
\hline largura & $57 \mathrm{~m}$ & \\
\hline
\end{tabular}

\begin{tabular}{|l|l|l|}
$\begin{array}{c}\text { Bibliografia } \\
\text { autor }\end{array}$ & titulo & localização \\
\hline Stern & TNEAEHL & vol. II/ pp. 776-777 \\
\hline Tsafrir & ACR & pp. 128-135 \\
\hline
\end{tabular}

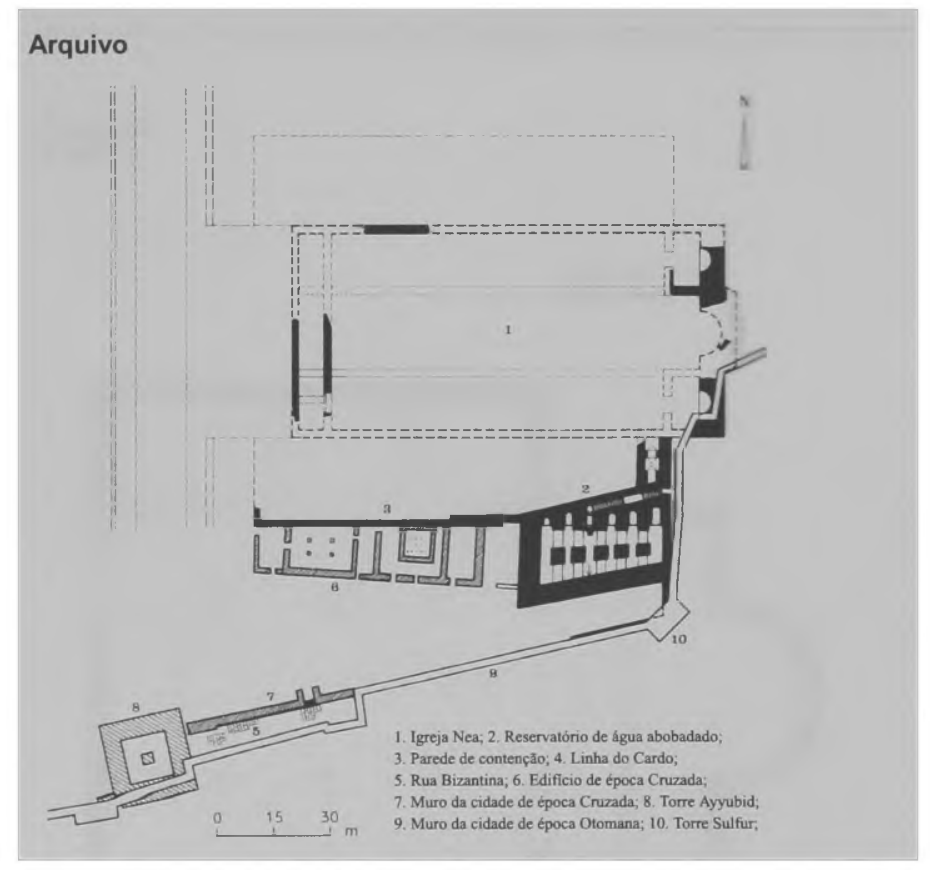

Planta dos restos de épocas bizantina, cruzada e árabe na parte sul do Bairro Judeu.
Ficha XLVI 


\begin{tabular}{|c|c|c|}
\hline $\begin{array}{l}\text { Nome da Igreja } \\
\text { Tipo }\end{array}$ & \multicolumn{2}{|c|}{$\begin{array}{l}\text { Igreja do Santo Zion } \\
\text { basílica triabsidal }\end{array}$} \\
\hline Orientação & & \\
\hline $\begin{array}{r}\text { Dimensões } \\
\text { tipo }\end{array}$ & valor & unidade \\
\hline comprimento & 52 & $m$ \\
\hline largura & 37 & $m$ \\
\hline
\end{tabular}

Datação

340 d.C.

Elem. de datação

Capitéis

\section{Informaçōes Complementares}

Essa igreja foi fundada no pico do monte Zion por Máximo, bispo de Jerusalém. Foi uma das igrejas mais importantes da Jerusalém Bizantina, mas durante a escavação encontraram-se poucos restos dela.

\section{Bibliografia}

\begin{tabular}{|l|l|l|}
$\begin{array}{c}\text { Bibliografia } \\
\text { autor }\end{array}$ & título & localização \\
\hline Stern & TNEAEHL & vol. II/ p. 778 \\
\hline
\end{tabular}




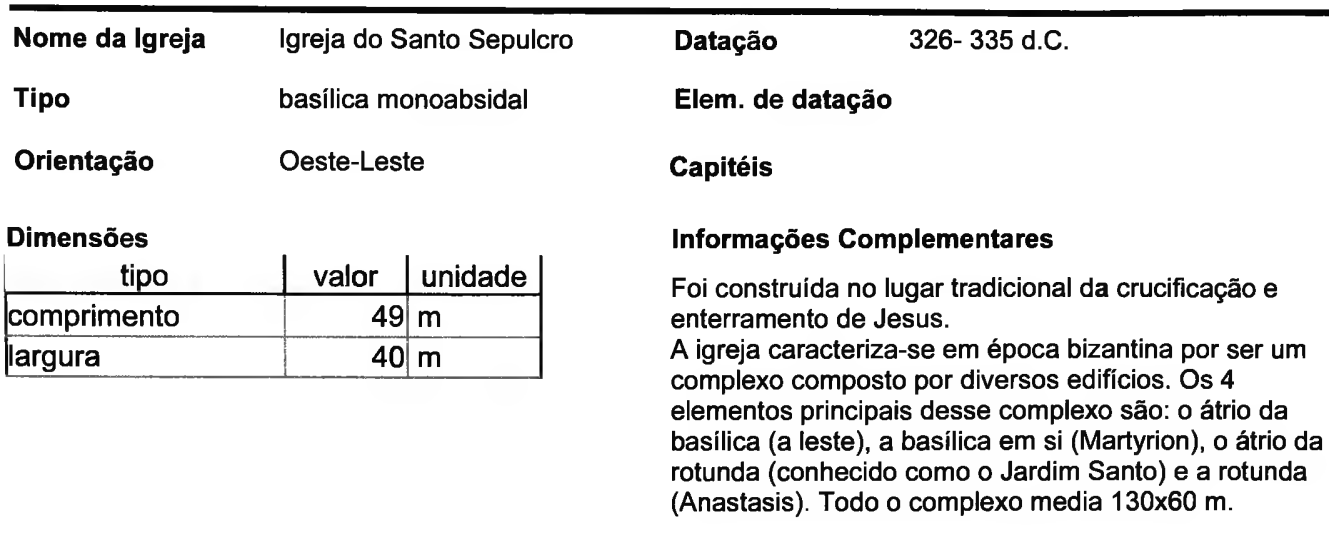

\begin{tabular}{|c|c|c|}
\hline $\begin{array}{c}\text { Bibliografia } \\
\text { autor } \\
\end{array}$ & título & localização \\
\hline Stern & TNEAEHL & vol. II/ pp. 779-781/ 796-797 \\
\hline Tsafrir & ACR & pp. $101-122$ \\
\hline
\end{tabular}

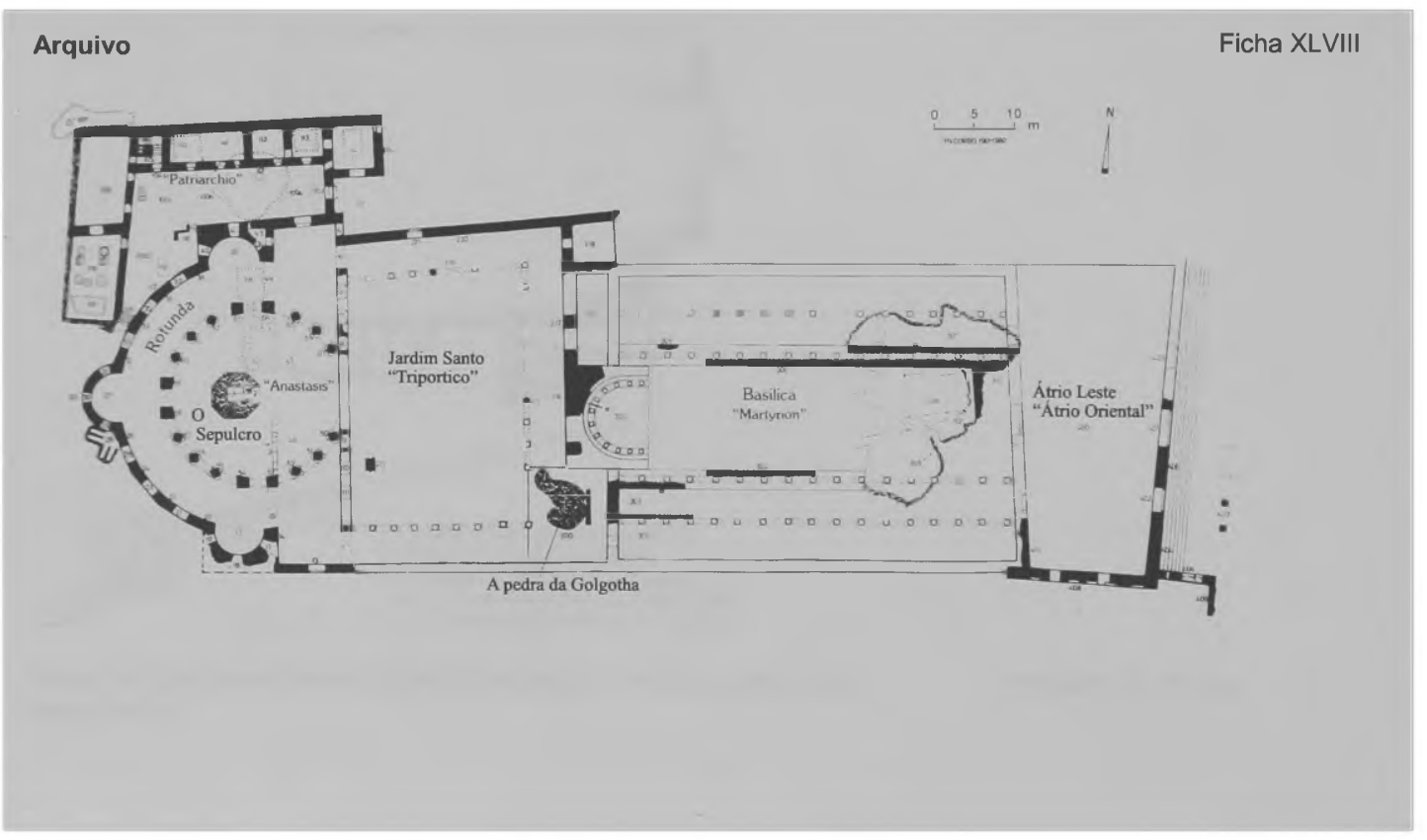

Planta da Igreja do Santo Sepulcro conforme configuração da época de Jerusalem03_01.jpg Constantino 


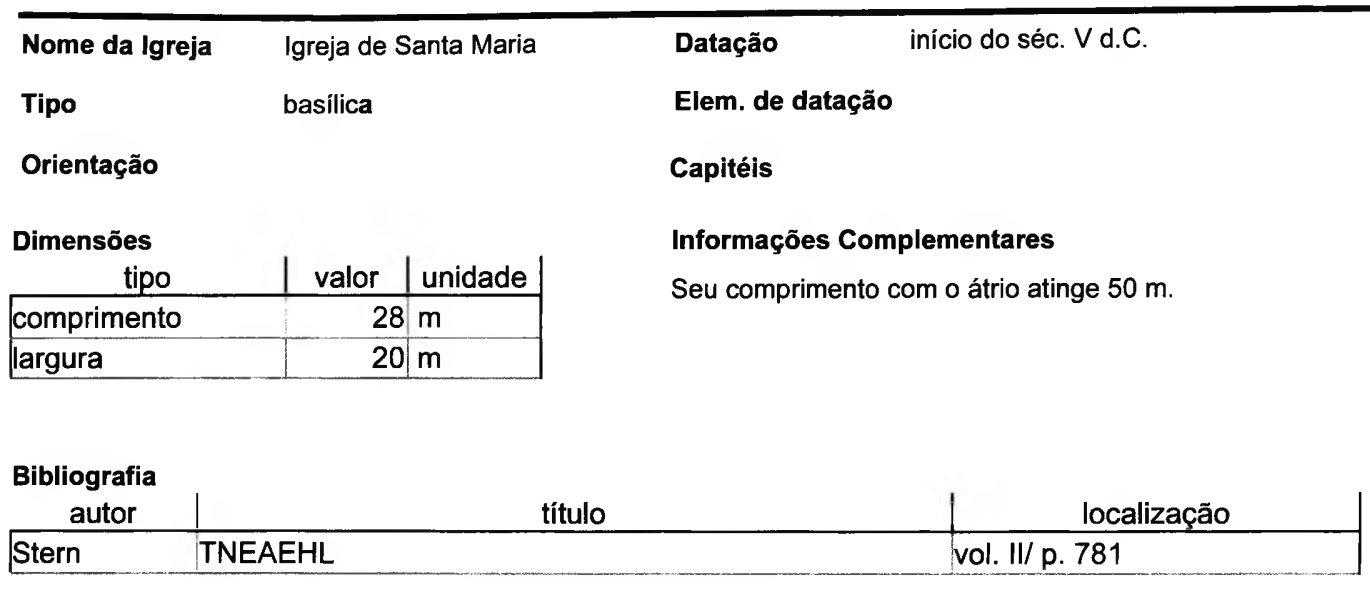




\begin{tabular}{|c|c|c|}
\hline Nome da Igreja & Igreja de Santo Estevão & Datação \\
\hline Tipo & basílica monoabsidal & Elem. de datação \\
\hline Orientação & & Capitéis \\
\hline Dimensões & & \multirow{4}{*}{$\begin{array}{l}\text { Informações Complementares } \\
\text { A abside da basilica é externa. }\end{array}$} \\
\hline tipo & \begin{tabular}{l|l} 
valor & unidade \\
\end{tabular} & \\
\hline comprimento & $33 \mathrm{~m}$ & \\
\hline largura & $20 \mathrm{~m}$ & \\
\hline
\end{tabular}

Bibliografia

\begin{tabular}{|l|l|l|}
$\begin{array}{c}\text { Bibliografia } \\
\text { autor }\end{array}$ & título & \multicolumn{1}{c|}{ localização } \\
\hline Stern & TNEAEHL & vol. II/ p. 782 \\
\hline
\end{tabular}




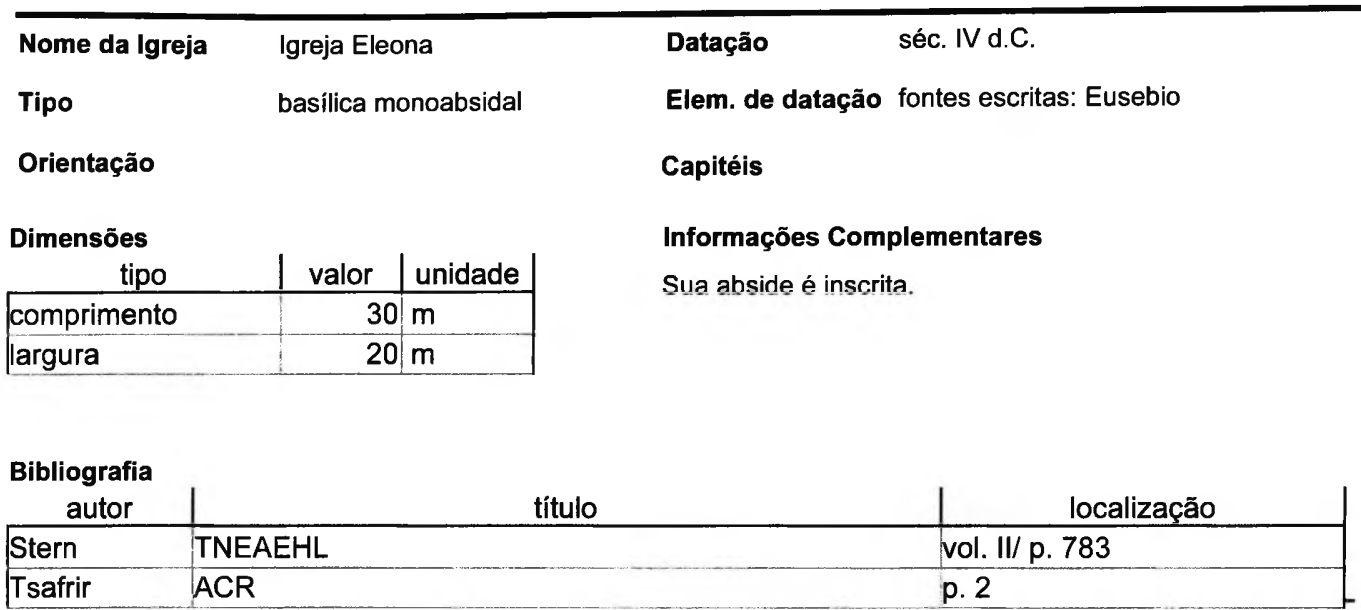

\section{Arquivo}

a.

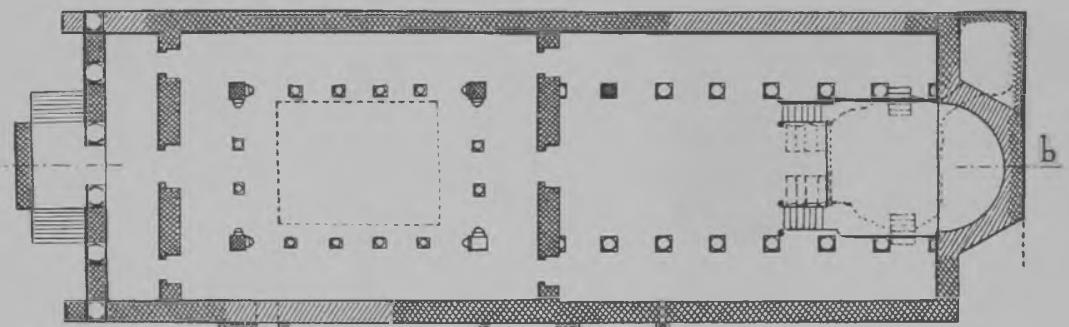

Paredes existentes

VIIIS Paredes reconstituidas

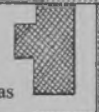

[

-....
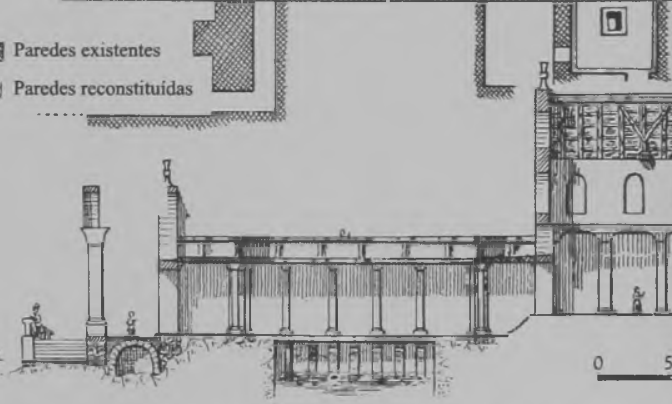

,
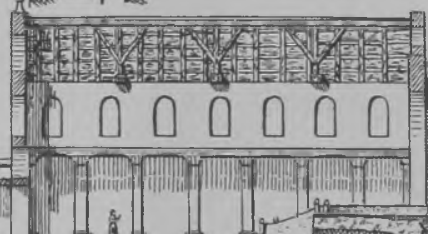

a

A igreja Eleona, no Monte das Oliveiras: planta e elevação reconstituídas.

Jerusalem10_01.jpg 


\begin{tabular}{|c|c|c|}
\hline Nome da lgreja & Igreja da Ascensão & Datação \\
\hline Tipo & circular (rotunda) & Elem. de datação \\
\hline Orientação & & Capitéis \\
\hline Dimensões & & Informações Complementares \\
\hline tipo & \begin{tabular}{l|l} 
valor & unidade \\
\end{tabular} & \multirow{2}{*}{ Localiza-se no cume do Monte das Oliveiras. } \\
\hline diâmetro & $25 \mathrm{~m}$ & \\
\hline
\end{tabular}

\begin{tabular}{|l|l|l|}
$\begin{array}{c}\text { Bibliografia } \\
\text { autor }\end{array}$ & \multicolumn{1}{c|}{ título } & \multicolumn{1}{c|}{ localização } \\
\hline Stern & TNEAEHL & vol. II/ p. 783 \\
\hline
\end{tabular}

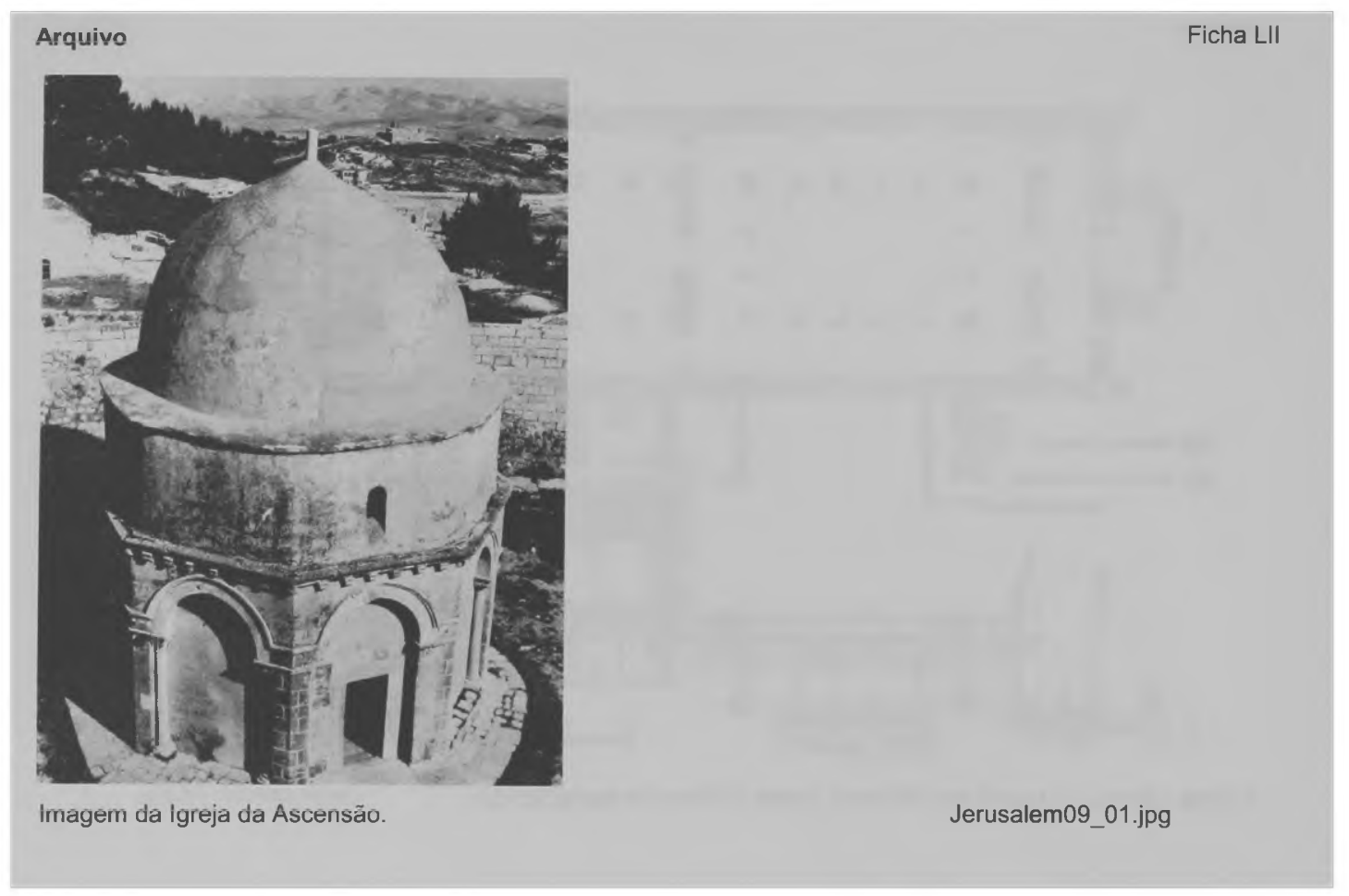




\begin{tabular}{|c|c|c|c|}
\hline Nome da Igreja & Igreja do Gethsemani & Datação & 385 d.C. \\
\hline Tipo & basílica triabsidal & Elem. de & \\
\hline Orientação & & Capitéis & corintios \\
\hline Dimensōes & & \multicolumn{2}{|c|}{ Informações Complementares } \\
\hline tipo & valor $\quad$ unidade & \multirow{3}{*}{\multicolumn{2}{|c|}{ Sua abside central é externa e duas laterais são internas }} \\
\hline comprimento & $22,5 \mathrm{~m}$ & & \\
\hline largura & \begin{tabular}{ll|l|}
16,5 & $\mathrm{~m}$ \\
\end{tabular} & & \\
\hline \multicolumn{4}{|l|}{ Bibliografia } \\
\hline autor & \multirow[b]{2}{*}{ TNEAEHL } & & localização \\
\hline Stern & & & vol. II/ pp. 783-784 \\
\hline
\end{tabular}




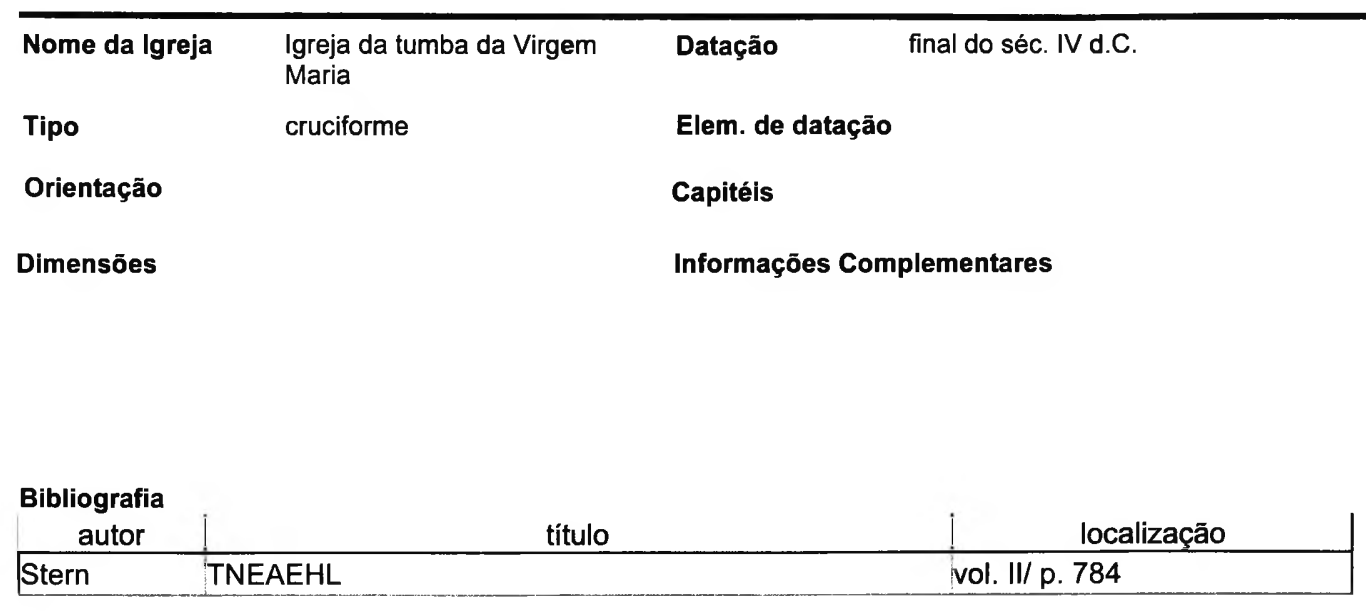

Arquivo

Ficha LIV 


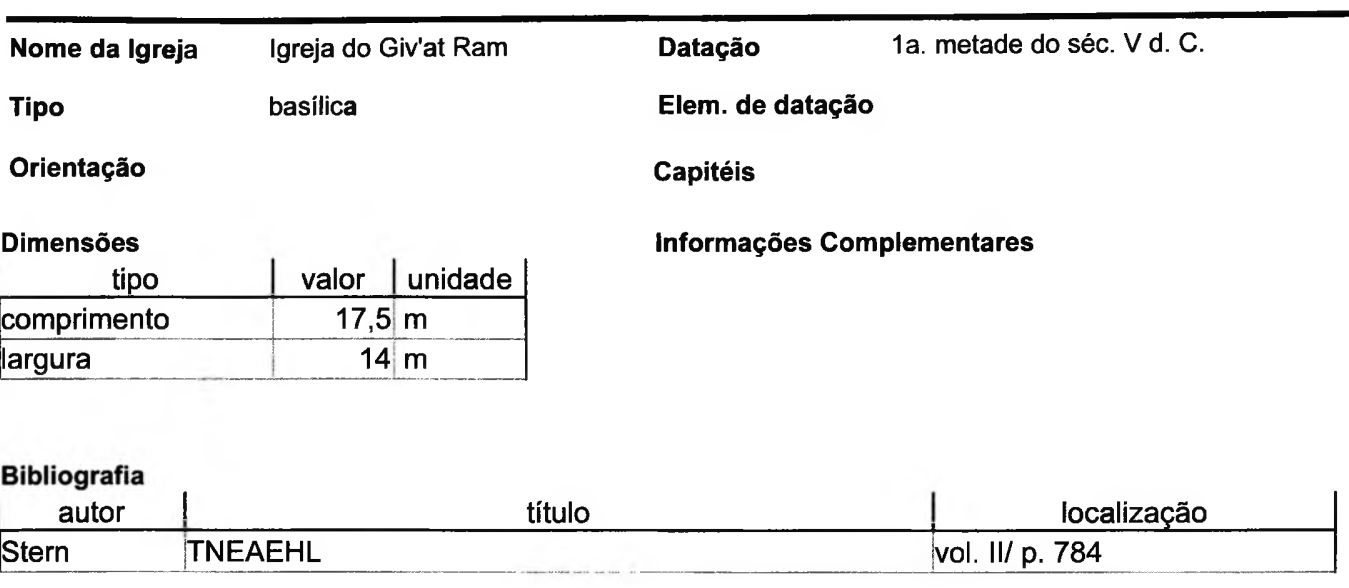

Arquivo

Ficha LV 


\begin{tabular}{|c|c|c|}
\hline Nome da Igreja & Igreja em Ketef Hinnom & século V d.C. \\
\hline Tipo & basilica & Elem. de datação \\
\hline Orientação & & Capitéis \\
\hline Dimensões & & Informaçōes Complementares \\
\hline tipo & valor $\quad$ unidade & \\
\hline comprimento & $45 \mathrm{~m}$ & \\
\hline largura & $25 \mathrm{~m}$ & \\
\hline
\end{tabular}

\begin{tabular}{|c|c|c|}
\hline $\begin{array}{c}\text { Bibliografia } \\
\text { autor }\end{array}$ & título & localização \\
\hline Stern & TNEAEHL & vol. II/ p. 784 \\
\hline
\end{tabular}




\section{Local Kefar Truman}

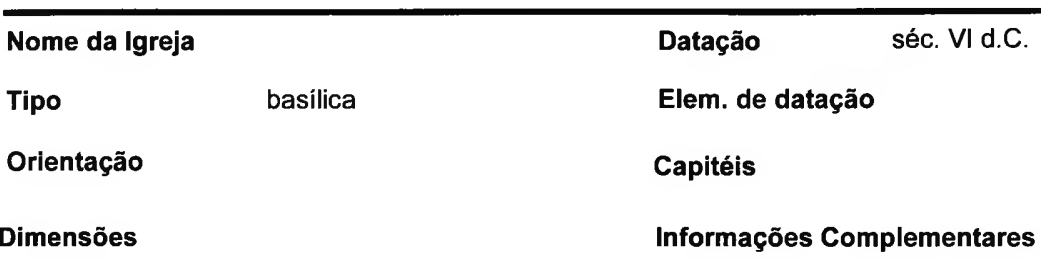

Não foi possivel determinar sua tipologia com maior exatidão porque não foi encontrado nenhum traço da abside na escavação.

\section{Bibliografia}

\begin{tabular}{|l|l|l|}
\multicolumn{1}{c|}{ autor } & título & \multicolumn{1}{c|}{ localização } \\
\hline Stern & TNEAEHL & vol. I/ p. 311 \\
\hline
\end{tabular}


Local

Nome da Igreja

Tipo

Orientação

basilica

Dimensões

\begin{tabular}{|l|c|l|}
\multicolumn{1}{|c|}{ tipo } & valor & unidade \\
\hline comprimento & $16 \mathrm{~m}$ \\
\hline largura & $13 \mathrm{~m}$ \\
\hline
\end{tabular}

\section{Datação \\ 576 d.C}

Elem. de datação inscrição no piso em mosaico

\section{Capitéis}

\section{Informações Complementares}

Não foi possivel determinar sua tipologia com maior exatidão porque a abside dessa igreja foi destruída.

Existem evidências que a igreja tinha nártex e átrio.

\begin{tabular}{|c|c|c|}
\hline $\begin{array}{c}\text { Bibliografia } \\
\text { autor }\end{array}$ & título & localização \\
\hline Stern & TNEAEHL & vol. III/ pp. 876-878 \\
\hline Tsafrir & ACR & pp. 277-282 \\
\hline
\end{tabular}

\section{Arquivo}

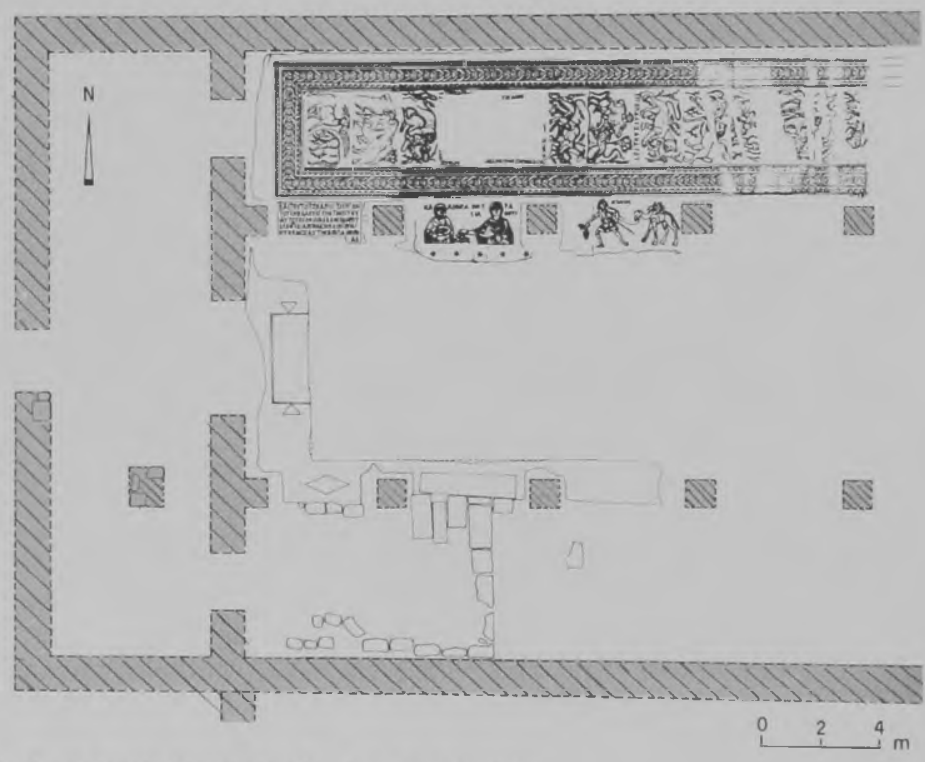

Planta da igreja (parcial) e do piso em mosaico 
Local Kurnub

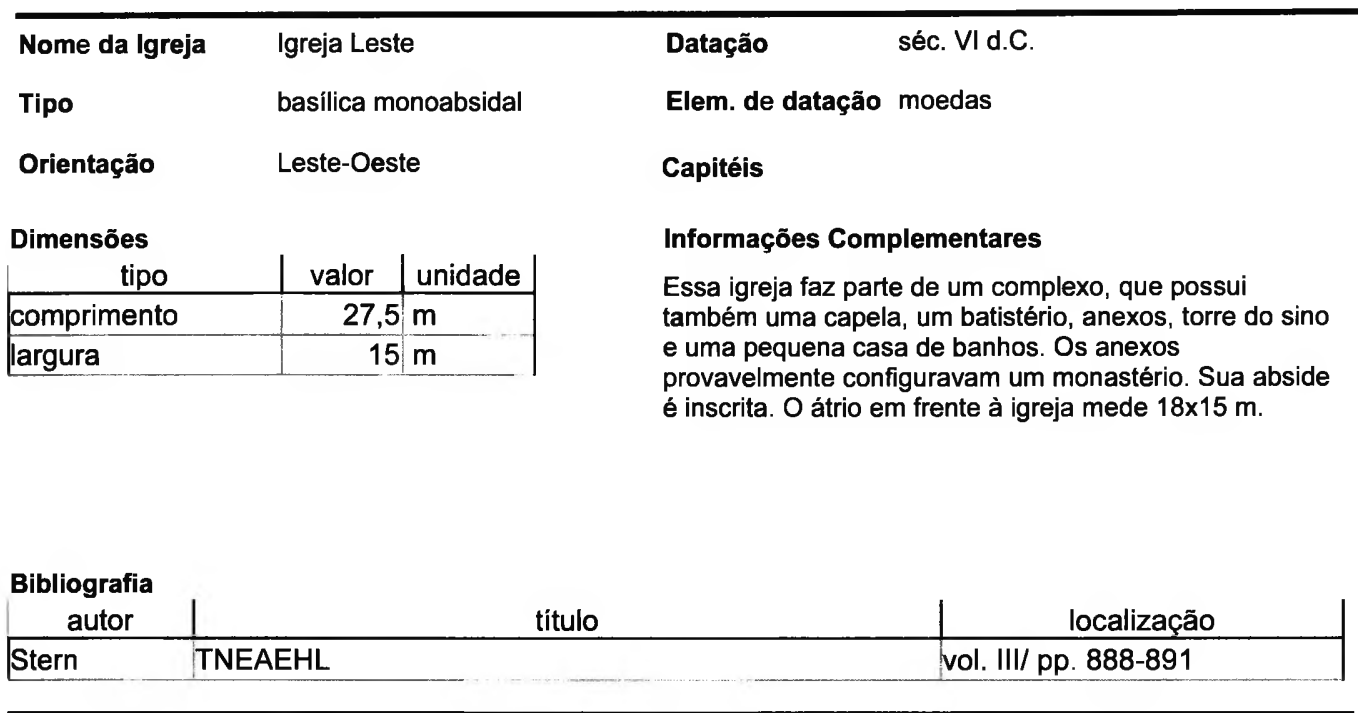

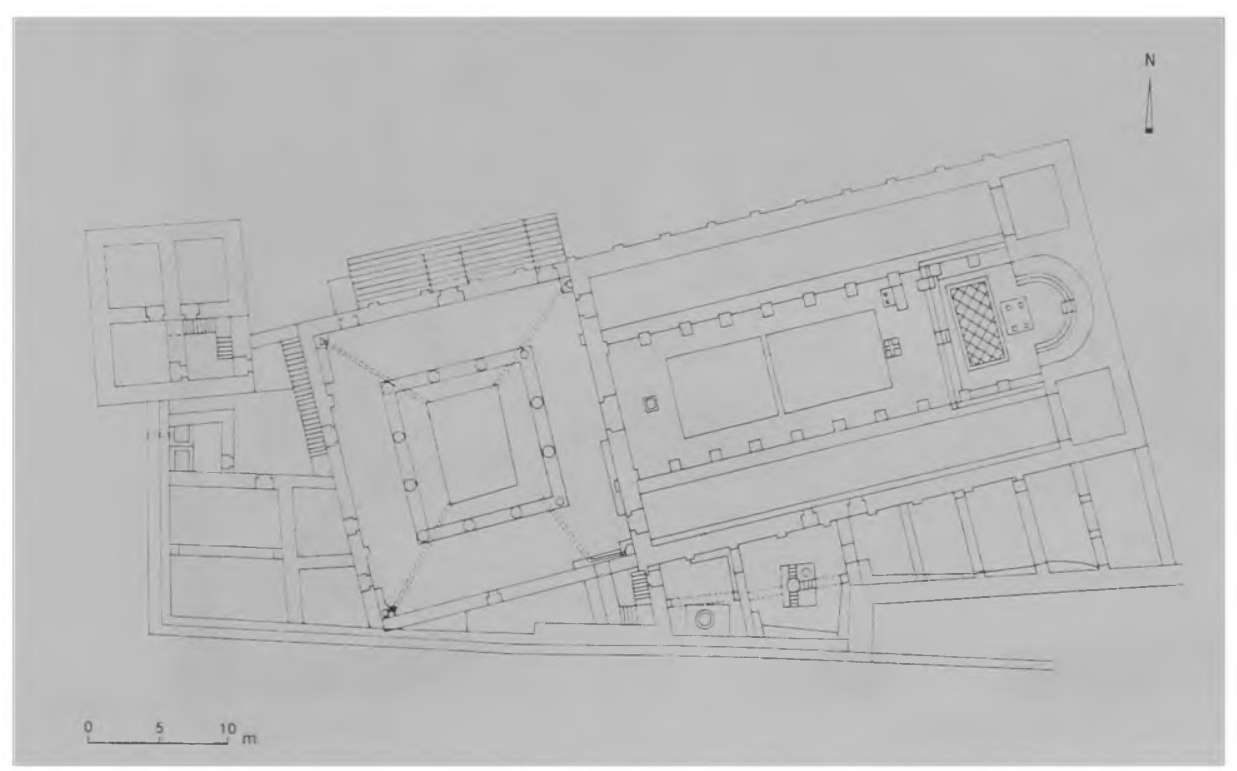




\begin{tabular}{|c|c|c|}
\hline Nome da Igreja & Igreja Oeste & anterior a 427 d.C. \\
\hline Tipo & basílica monoabsidal & Elem. de datação piso em mosaico e moedas \\
\hline Orientação & & Capitéis \\
\hline Dimensōes & & Informações Complementares \\
\hline tipo & \begin{tabular}{l|l|} 
valor & unidade \\
\end{tabular} & Apesar dessa igreja ser menor que a Igreja Leste, sua \\
\hline comprimento & $17,5 \mathrm{~m}$ & planta é bastante parecida. Ela também tem alguns \\
\hline largura & $10 \mathrm{~m}$ & $\begin{array}{l}\text { anexos ao sul, mas sem a pia batismal. Sua abside é } \\
\text { inscrita. }\end{array}$ \\
\hline
\end{tabular}

\begin{tabular}{|l|c|c|}
$\begin{array}{c}\text { Bibliografia } \\
\text { autor }\end{array}$ & título & localização \\
\hline Stern & TNEAEHL & vol. III/ pp. 889-891 \\
\hline
\end{tabular}

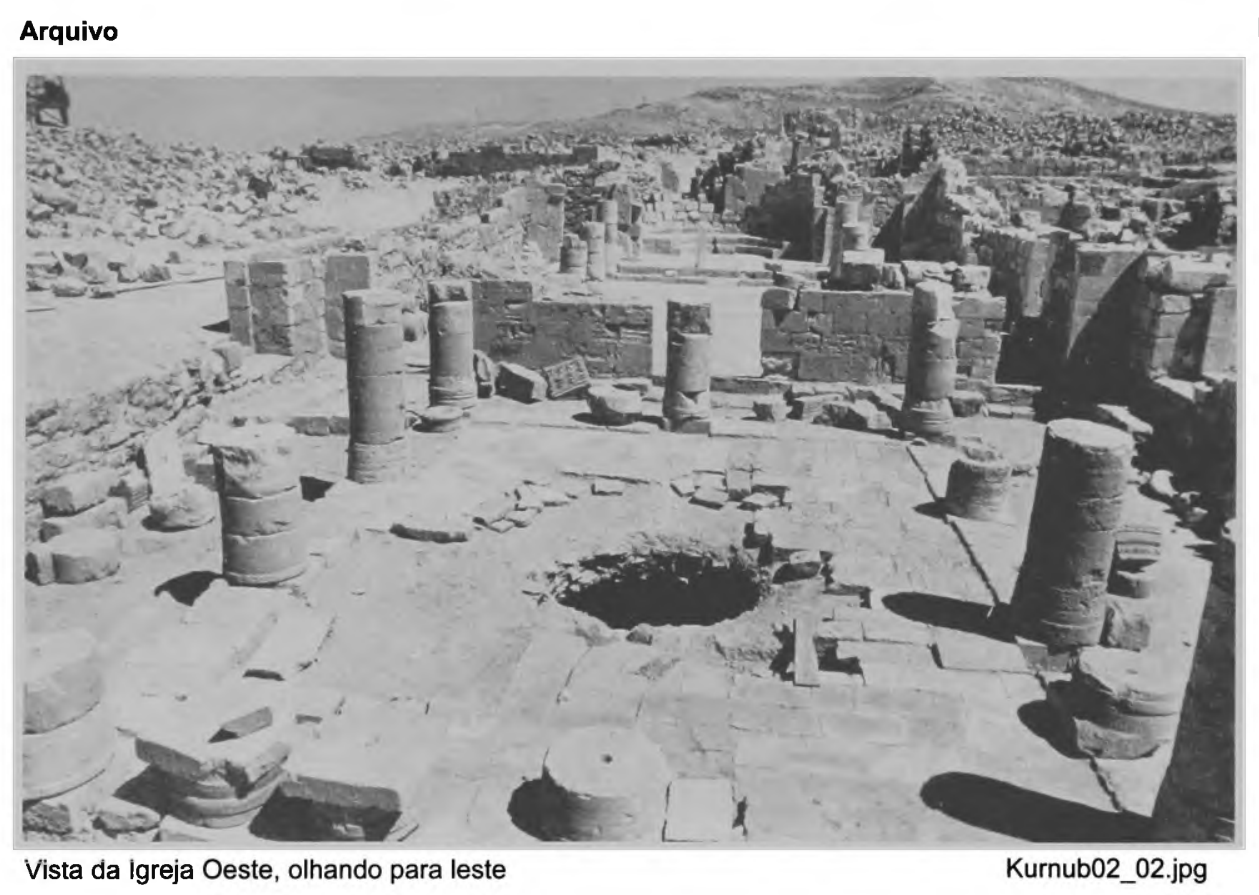


Local Kursi

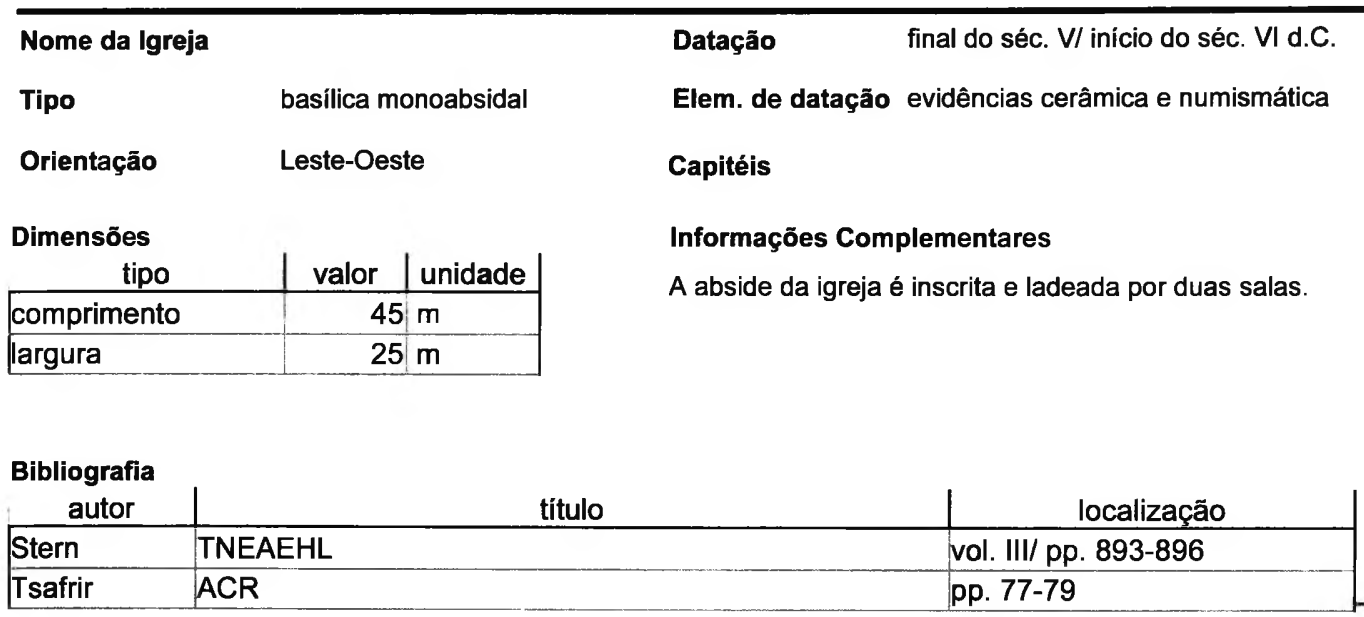

Arquivo

Ficha LXI

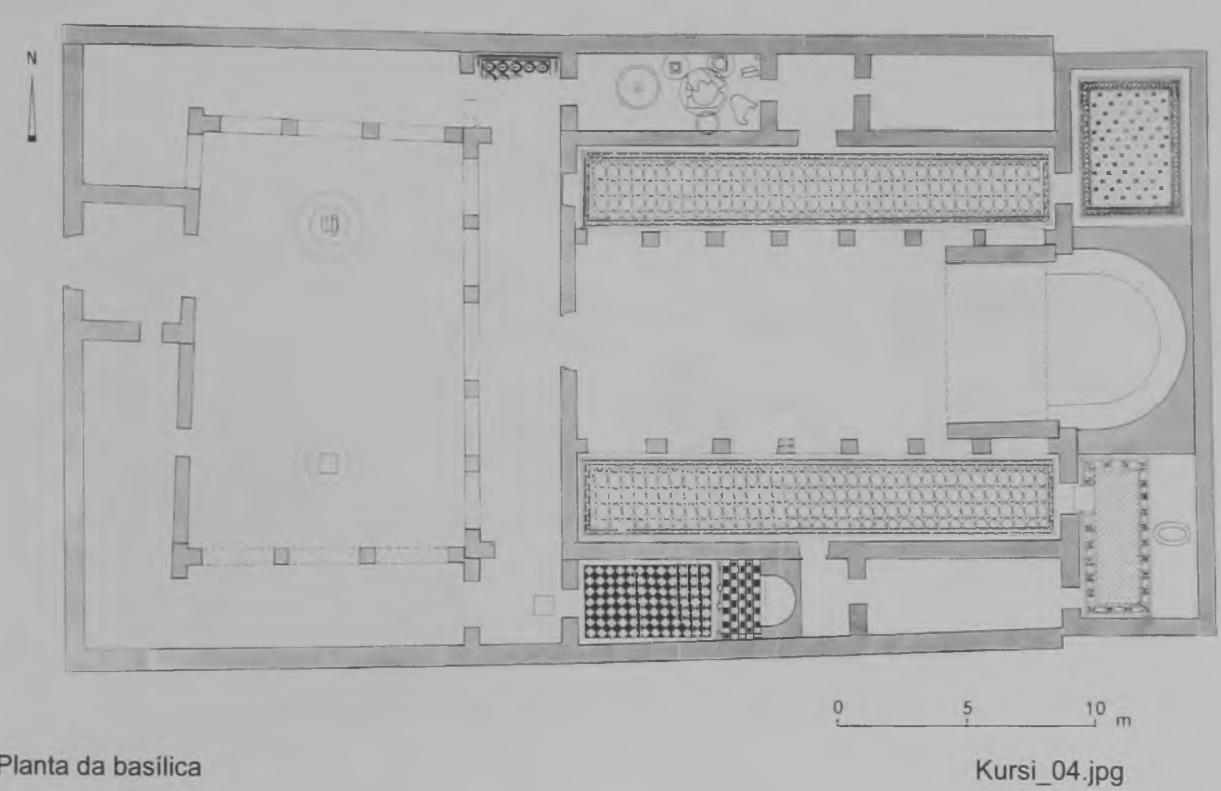




\section{Local Magen}

Nome da Igreja Edificio A

Tipo

basilica

Orientação

Norte-Sul

Dimensões

\section{Bibliografia}

\begin{tabular}{|c|c|c|}
$\begin{array}{c}\text { autor } \\
\text { Tsafrir }\end{array}$ ACR & título & localização \\
\hline
\end{tabular}

Arquivo
Datação

séc. VI d.C.

Elem. de datação

\section{Capitéis}

\section{Informações Complementares}

A abside da igreja foi destruida por construções posteriores. A sua planta geral sem a abside tem a forma de cabide.

Essa igreja tem nártex e átrio.

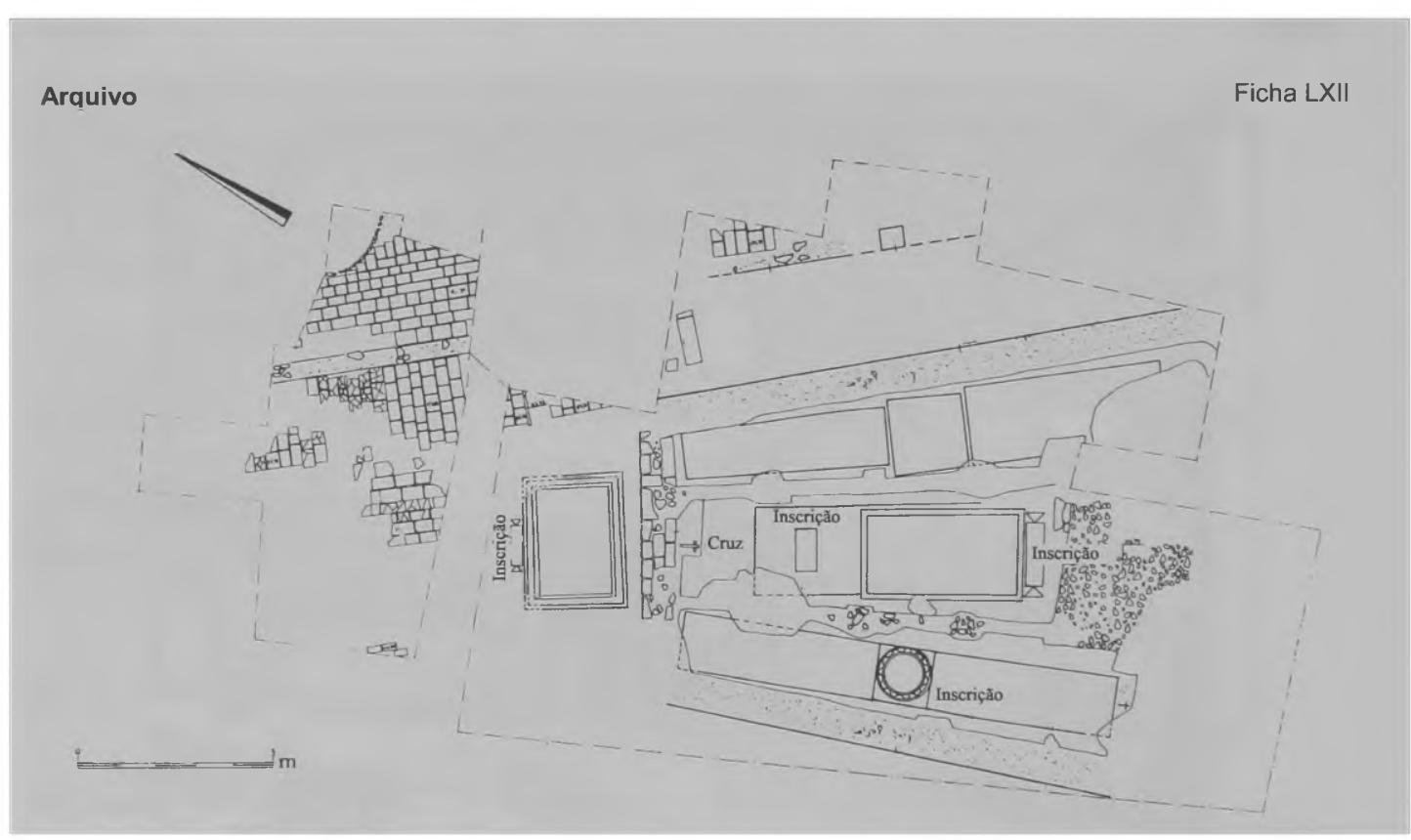

Planta em forma de cabide da Igreja A 
Local Mareshah

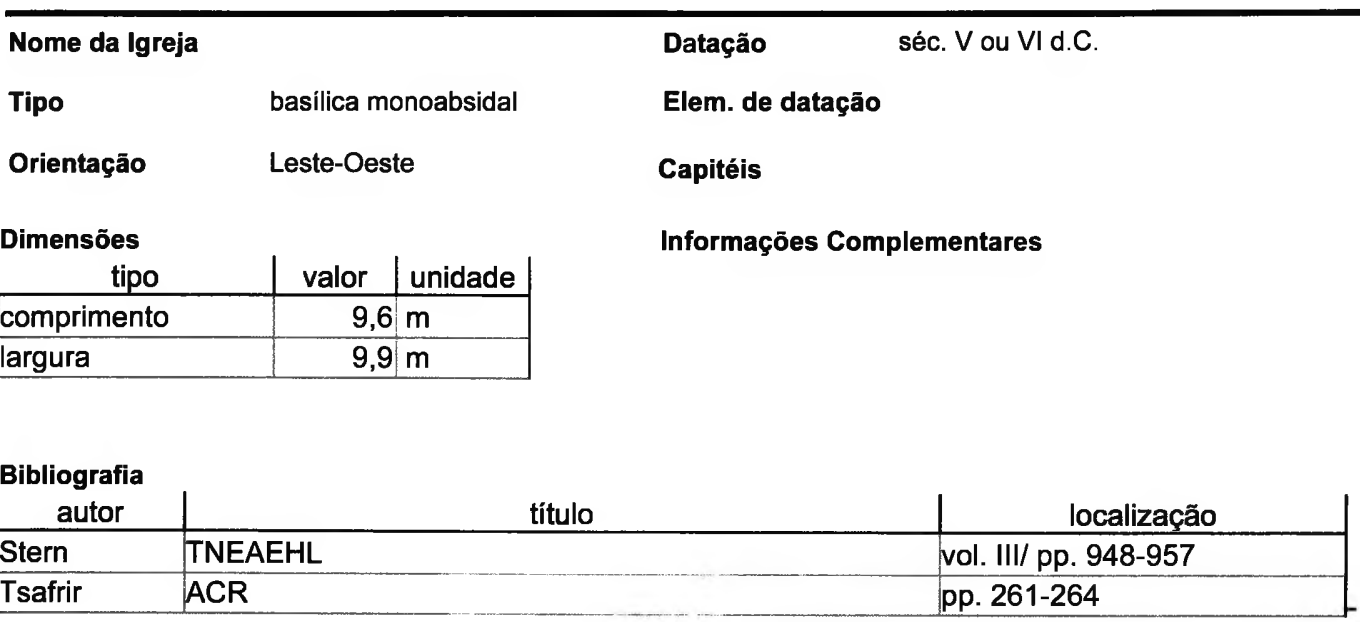

Arquivo

Ficha LXIII

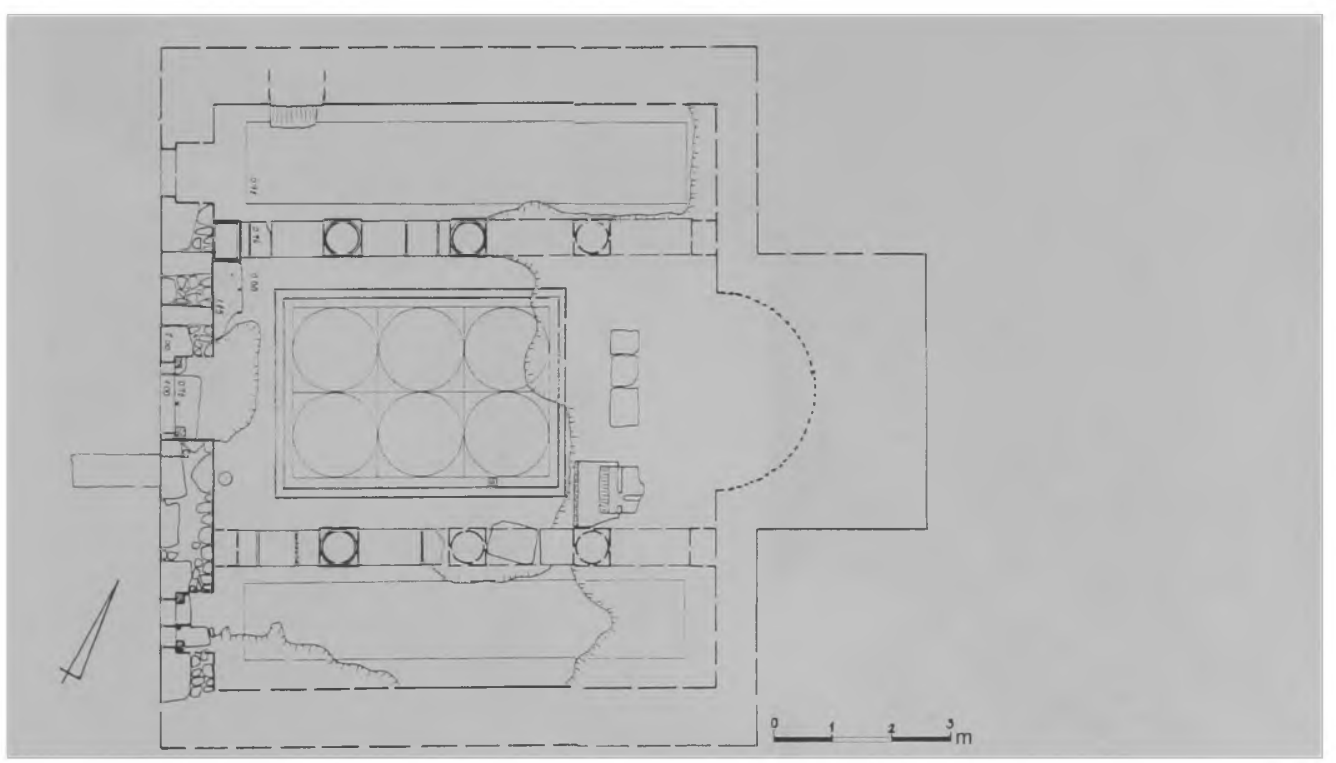

Planta da igreja

Maresha_02.jpg 


\section{Local Medeba}

Nome da Igreja

Tipo

Orientação

Dimensões

\begin{tabular}{|c|r|r|}
\multicolumn{1}{c|}{ tipo } & valor & unidade \\
\hline comprimento & 38 & $\mathrm{~m}$ \\
\hline
\end{tabular}

\section{Datação}

2a metade do séc. VI d.C.

Elem. de datação

\section{Capitéis}

\section{Informações Complementares}

A basílica tinha 3 naves, nártex e átrio.

\begin{tabular}{|l|l|l|}
$\begin{array}{c}\text { Bibliografia } \\
\text { autor }\end{array}$ & título & \multicolumn{1}{c|}{ localização } \\
\hline Stern & TNEAEHL & vol. III/ pp. $993-995$ \\
\hline
\end{tabular}

\section{Arquivo}

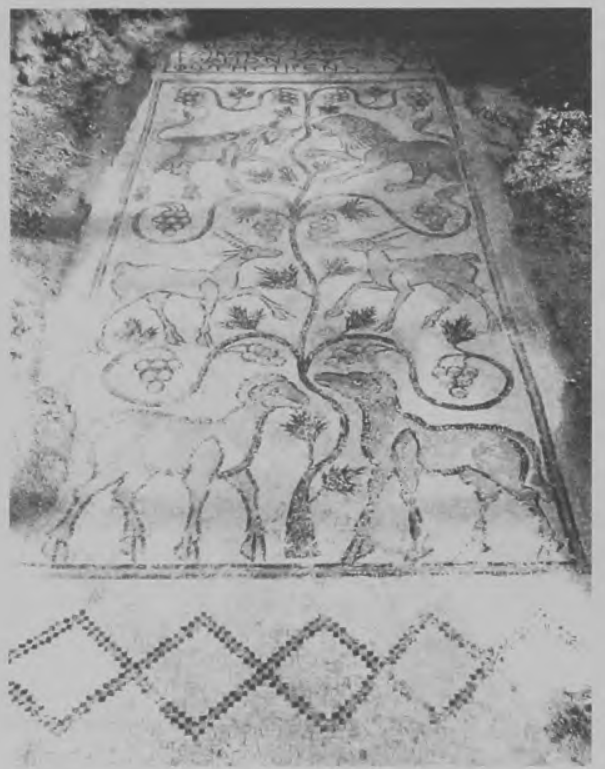




\begin{tabular}{|c|c|c|}
\hline Nome da Igreja & Igreja da Virgem Maria & final do séc. VI d.C. \\
\hline Tipo & basílica & Elem. de datação \\
\hline Orientação & & Capitéis \\
\hline \multirow[t]{2}{*}{ Dimensões } & & Informaçōes Complementares \\
\hline & & $\begin{array}{l}\text { Na sua construção, parte do edifício cobriu a sala } \\
\text { "Hyppolitus", uma sala com mosaicos de época romana, } \\
\text { anterior à existência da igreja. }\end{array}$ \\
\hline \multicolumn{3}{|l|}{ Bibliografia } \\
\hline autor & título & localização \\
\hline Stern & EHL & vol. III/ pp. 995-997 \\
\hline
\end{tabular}

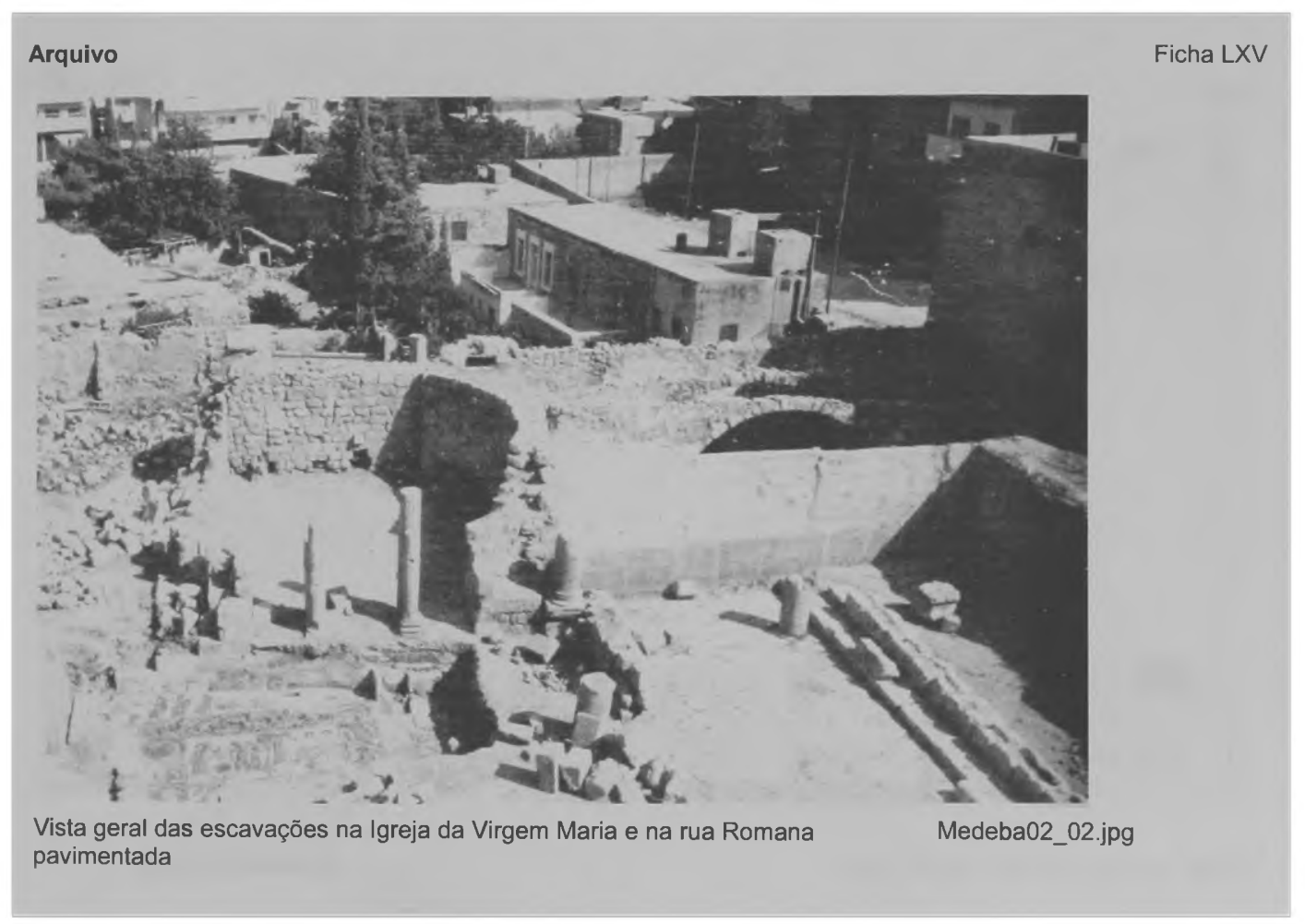




\begin{tabular}{|c|c|c|c|}
\hline Nome da Igreja & \multicolumn{2}{|c|}{ Igreja do mapa de $\mathrm{Me}$} & metade do séc. VI d.C. \\
\hline Tipo & \multicolumn{2}{|c|}{ basílica monoabsidal } & Elem. de datação piso em mosaico \\
\hline Orientação & \multicolumn{2}{|c|}{ Leste-Oeste } & Capitéis \\
\hline \multicolumn{3}{|l|}{ Dimensões } & \multirow{4}{*}{$\begin{array}{l}\text { Informações Complementares } \\
\text { A igreja é assim chamada porque em seu piso há um } \\
\text { mosaico de um mapa onde se localizam várias igrejas e } \\
\text { cidades da Palestina. Ela também é conhecida como } \\
\text { "Igreja Norte" }\end{array}$} \\
\hline tipo & valor & unidade & \\
\hline comprimento & 25 & $m$ & \\
\hline largura & & $m$ & \\
\hline
\end{tabular}

\begin{tabular}{|l|c|c|}
$\begin{array}{c}\text { Bibliografia } \\
\text { autor }\end{array}$ & título & localização \\
\hline Stern & TNEAEHL & vol. III/ pp. 997-999 \\
\hline
\end{tabular}

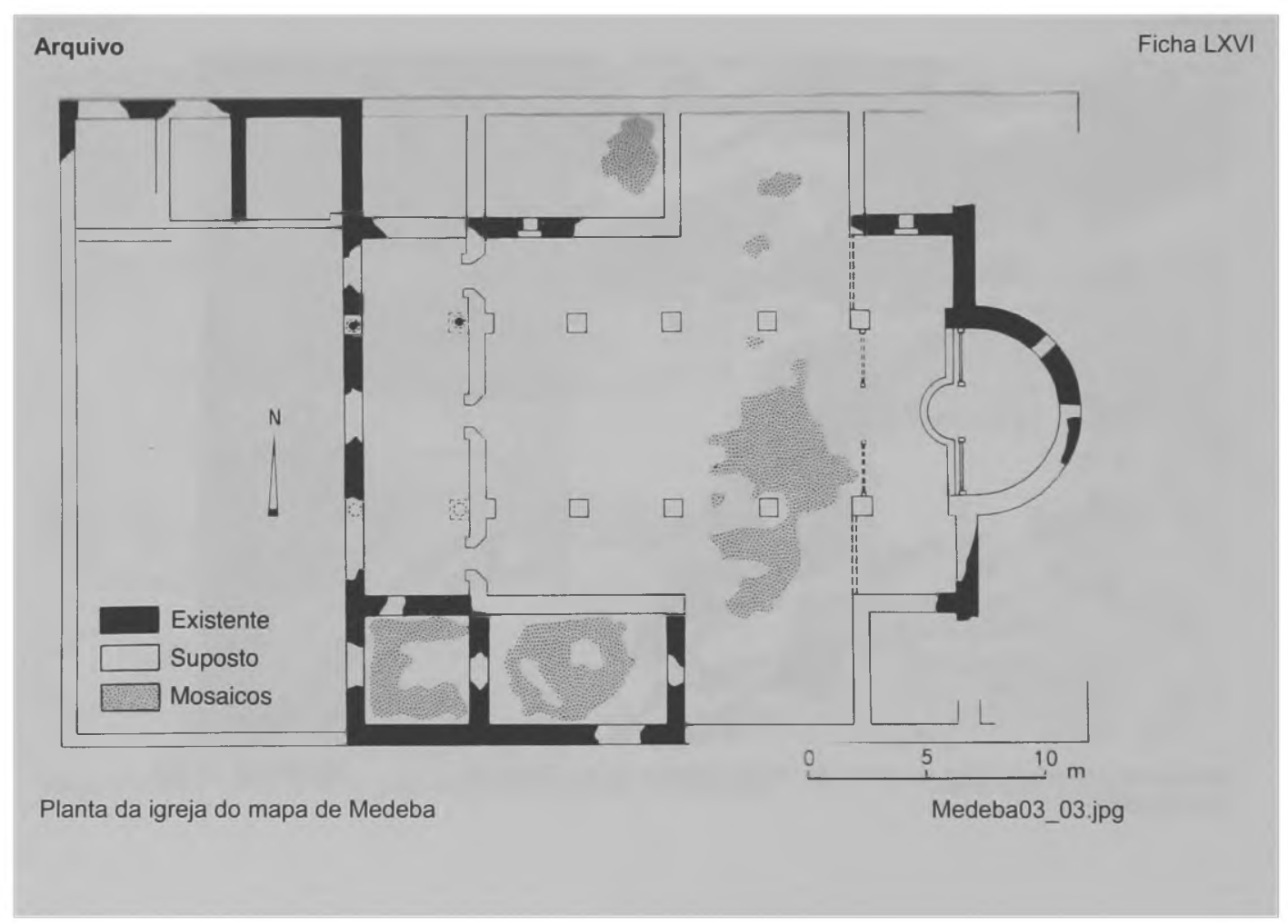




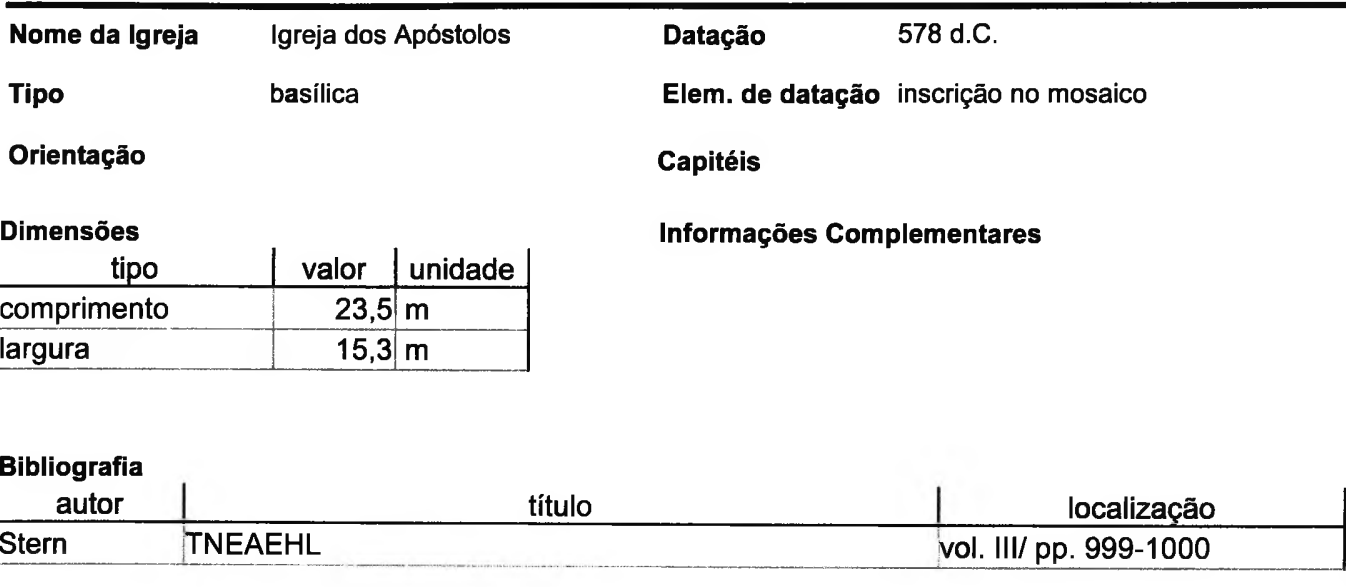

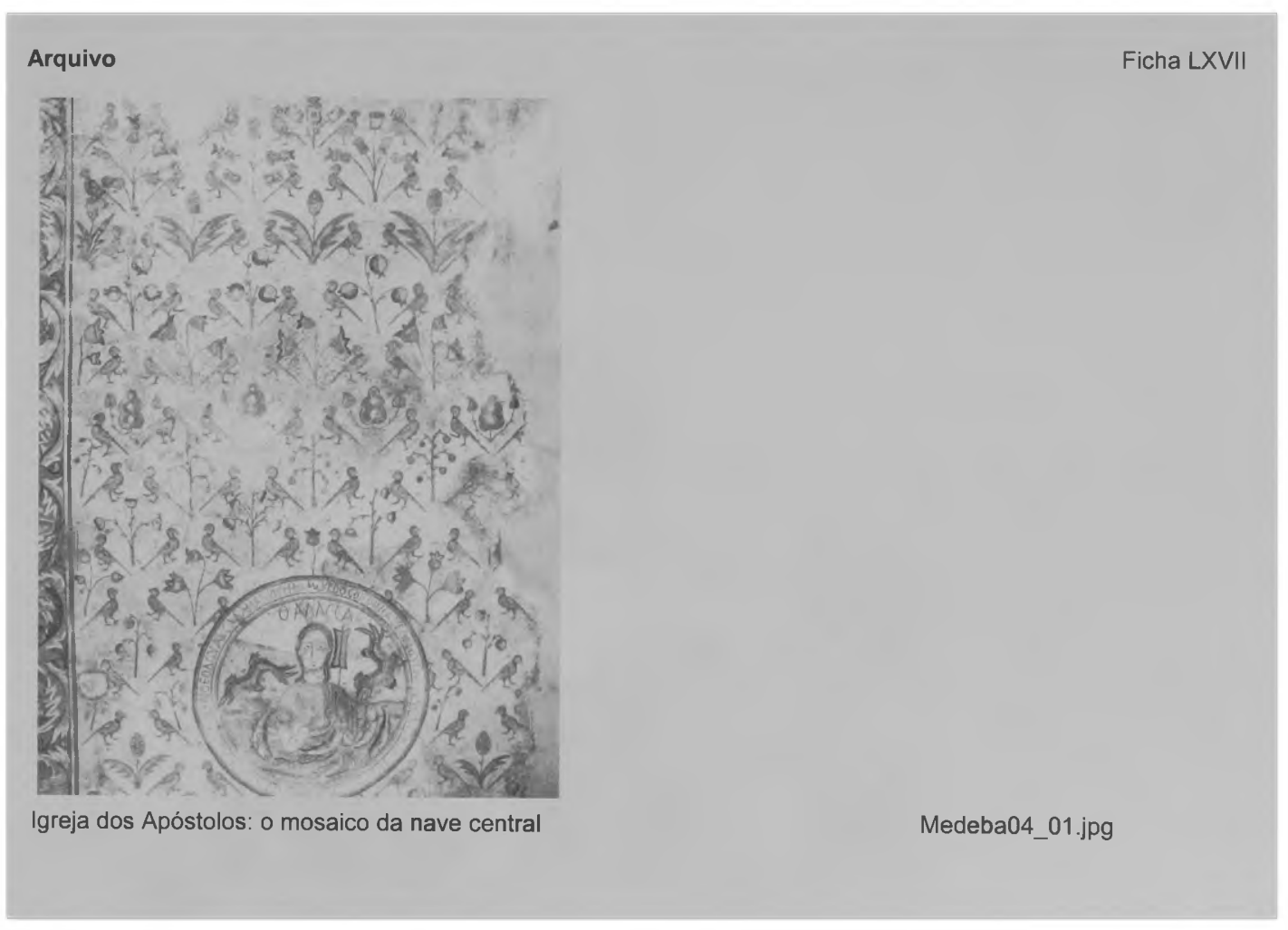




\section{Local Mishmar Ha-'Emeq}

\begin{tabular}{|c|c|c|}
\hline Nome da Igreja & \multirow[b]{2}{*}{ basilica monoabsidal } & séc. V d.C. \\
\hline Tipo & & Elem. de datação evidência cerâmica \\
\hline Orientação & Leste-Oeste & Capitéis \\
\hline \multicolumn{2}{|l|}{ Dimensōes } & Informaçōes Complementares \\
\hline tipo & \begin{tabular}{l|l|} 
valor & unidade \\
\end{tabular} & \multirow{3}{*}{$\begin{array}{l}\text { As evidênicas arqueológicas identificaram diversas fases } \\
\text { da construção dessa igreja. Sua abside é externa e foi } \\
\text { acrescentada no lado leste do edificio posteriormente à } \\
\text { sua construção. }\end{array}$} \\
\hline comprimento & $10 \mathrm{~m}$ & \\
\hline largura (nave central & \begin{tabular}{ll|l}
4,5 & $m$ \\
\end{tabular} & \\
\hline
\end{tabular}

\begin{tabular}{|c|c|c|}
$\begin{array}{c}\text { Bibliografia } \\
\text { autor }\end{array}$ & título & \multicolumn{1}{c|}{ localização } \\
\hline Stern & TNEAEHL & vol. I/ p. 311 \\
\hline
\end{tabular}


Local

Mount Nebo

\begin{tabular}{|c|c|c|}
\hline Nome da Igreja & $\begin{array}{l}\text { Memorial de Moisés em } \\
\text { Siyagha }\end{array}$ & segunda metade do séc. VI d.C. \\
\hline Tipo & basilica triabsidal & Elem. de datação \\
\hline Orientação & Leste-Oeste & Capitéis \\
\hline Dimensões & & Informações Complementares \\
\hline tipo & valor $\mid$ unidade & \multirow{3}{*}{$\begin{array}{l}\text { No local onde essa igreja foi construída, o pico Siyagha, } \\
\text { havia no séc. IV uma igreja memorial em honra a Moisés } \\
\text { As três absides dessa igreja estão dispostas em forma } \\
\text { de trevo, o que difere da configuração usual da basílica } \\
\text { triabsidal. }\end{array}$} \\
\hline comprimento & $36 \mathrm{~m}$ & \\
\hline largura & $14,5 \mathrm{~m}$ & \\
\hline
\end{tabular}

Bibliografia

\begin{tabular}{|l|l|l|}
$\begin{array}{c}\text { autor } \\
\text { Stern }\end{array}$ & título & localização \\
\hline
\end{tabular}

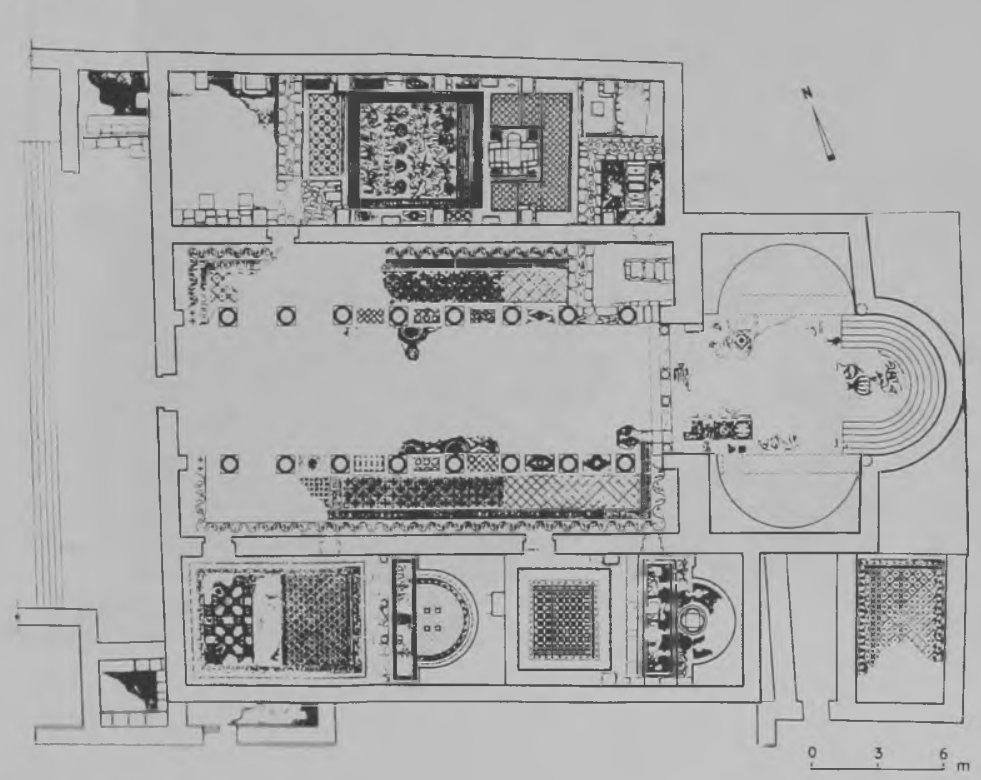

Planta da igreja

MountNebo01_02.jpg 


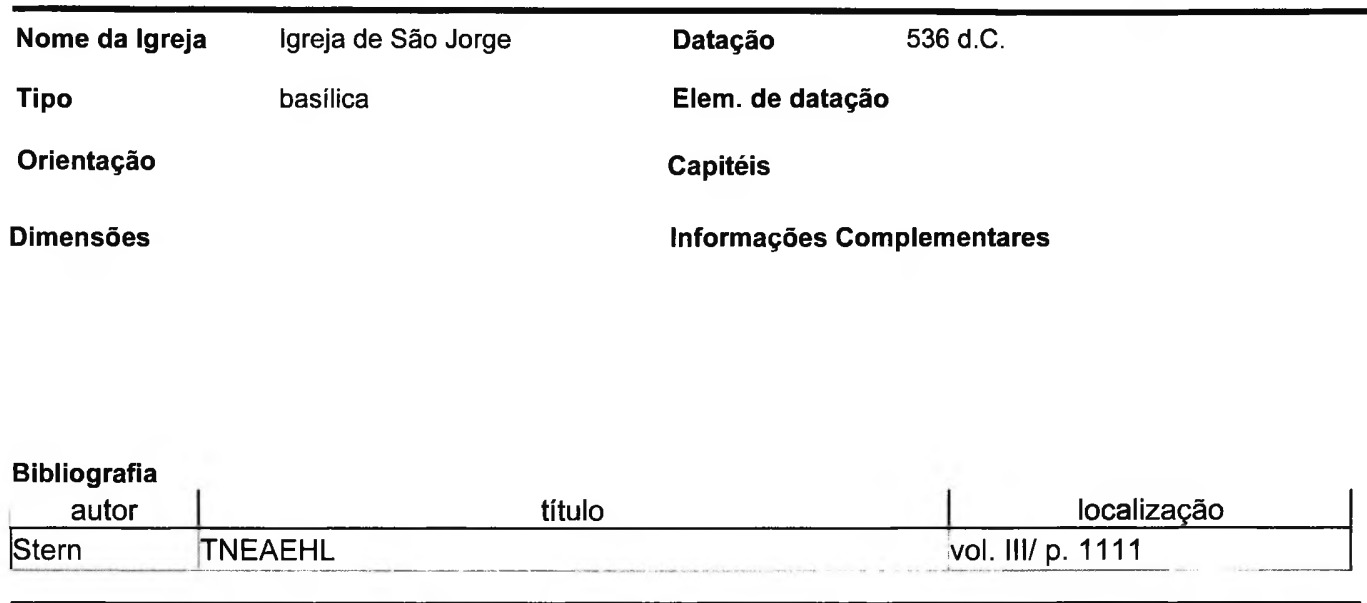

\section{Arquivo}

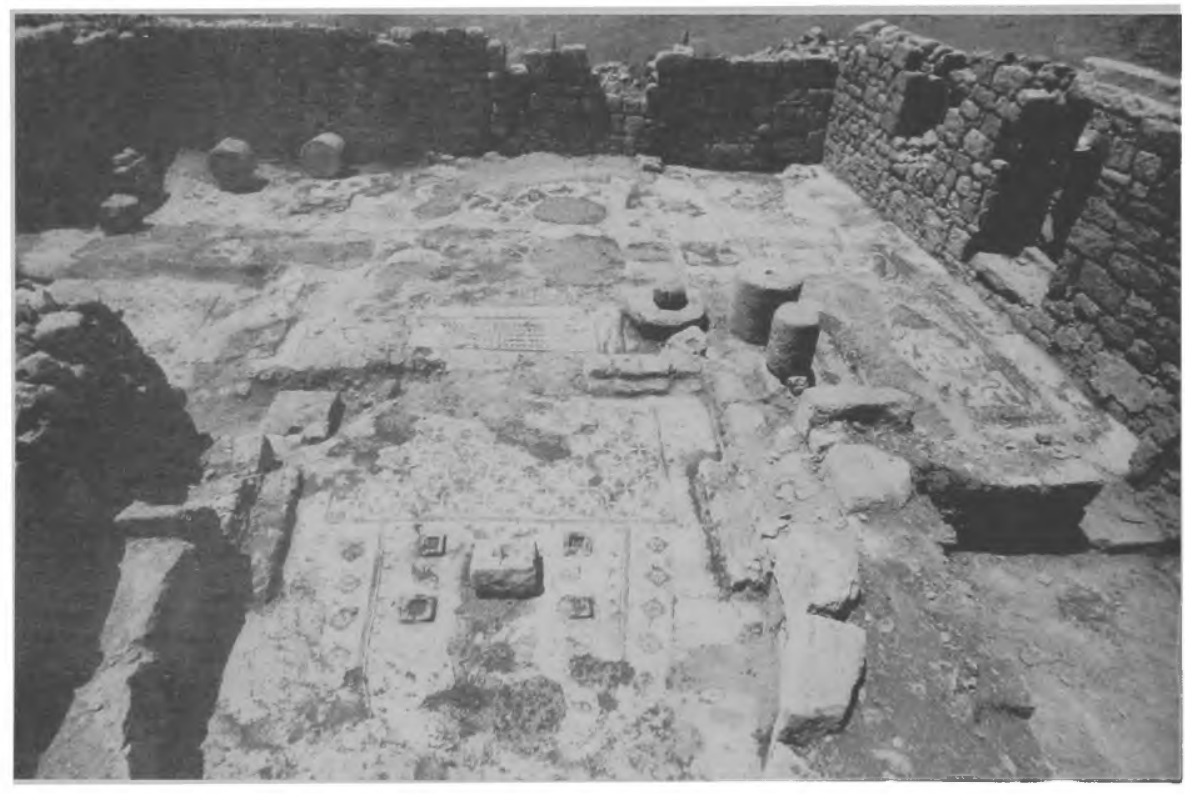




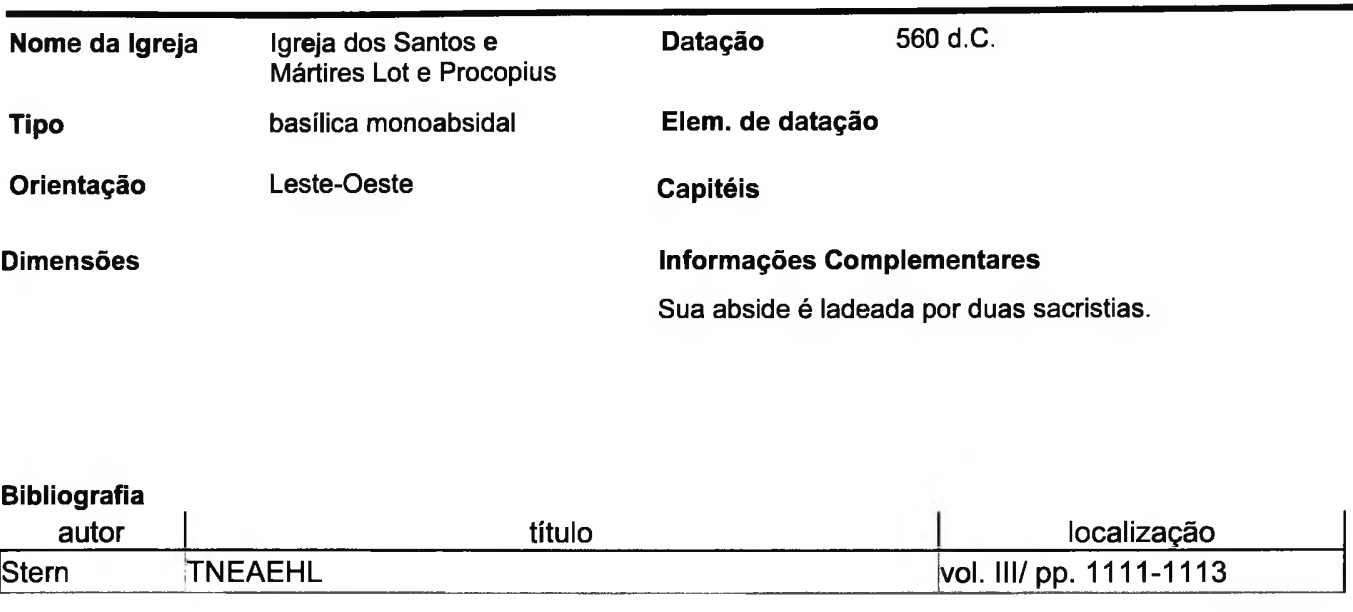

\section{Arquivo}

Ficha LXXI

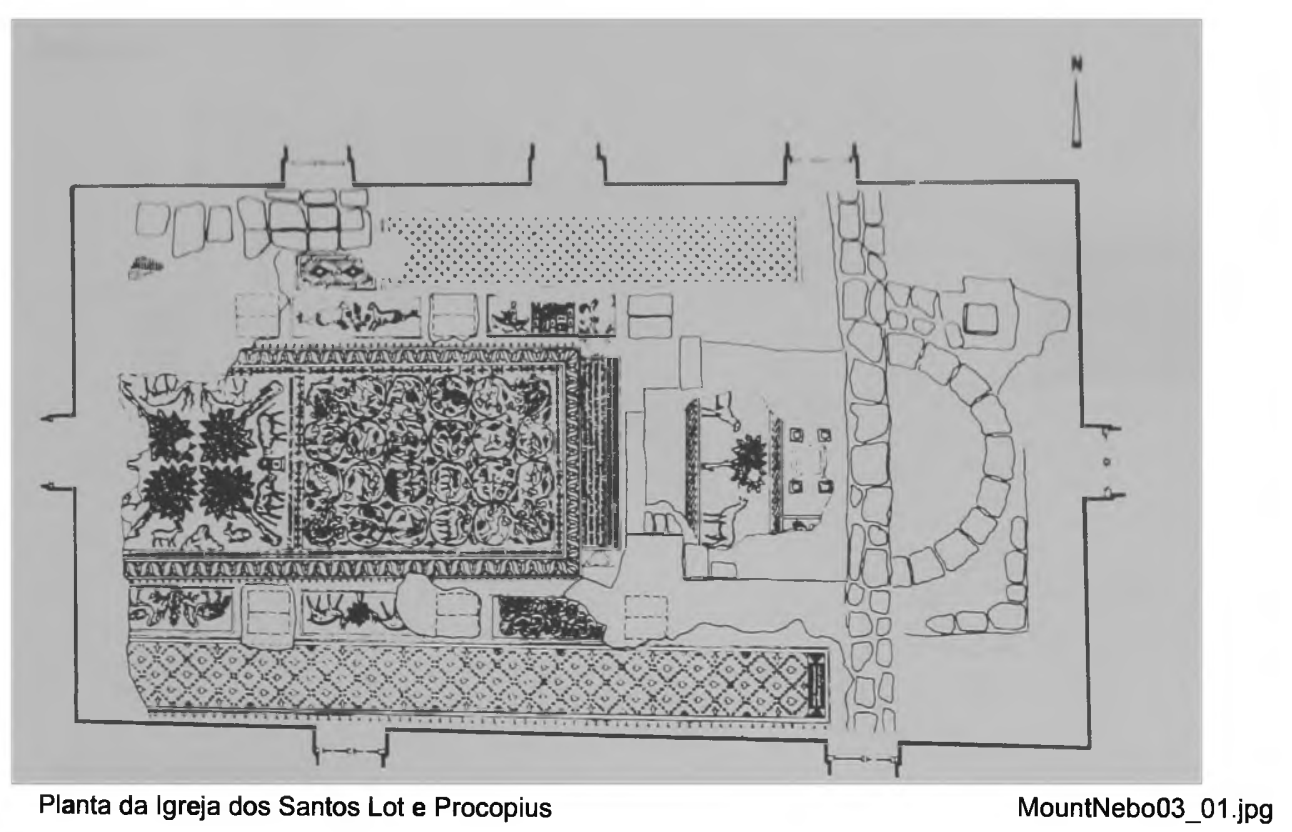




\begin{tabular}{|c|c|c|}
\hline Nome da Igreja & Igreja de Amos e Casiseos & segunda metade do séc. $V$ d.C. \\
\hline Tipo & basilica monoabsidal & Elem. de datação \\
\hline Orientação & Leste-Oeste & Capitéis \\
\hline \multirow[t]{2}{*}{ Dimensōes } & & Informações Complementares \\
\hline & & $\begin{array}{l}\text { É a igreja mais antiga da cidade, e tem o nome dos seus } \\
\text { benfeitores. } \\
\text { A capela ao norte da igreja foi adicionada } \\
\text { posteriormente, no tempo do bispo João - segunda } \\
\text { metade do séc. VI d.C. }\end{array}$ \\
\hline \multicolumn{3}{|l|}{ Bibliografia } \\
\hline autor & título & localização \\
\hline Stern & $\mathrm{EHL}$ & vol. III/ pp. 1113-1115 \\
\hline
\end{tabular}

\section{Arquivo}

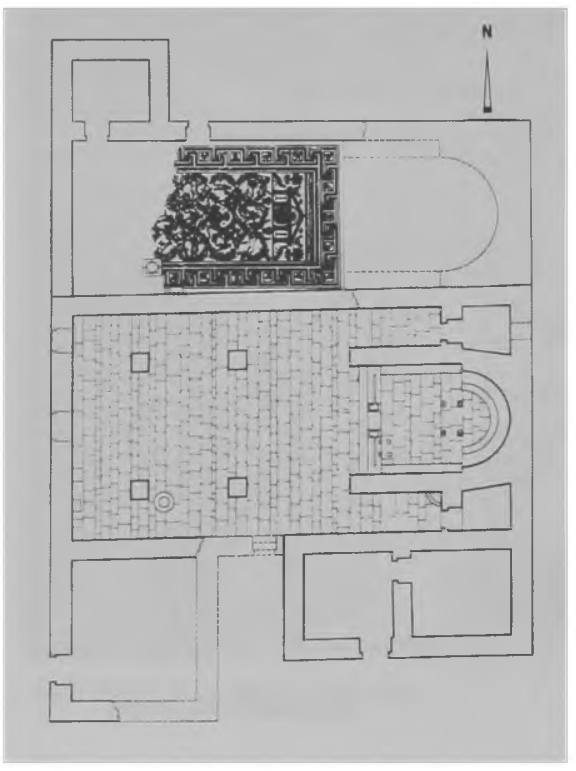

Planta da Igreja de Amos e Casiseos 


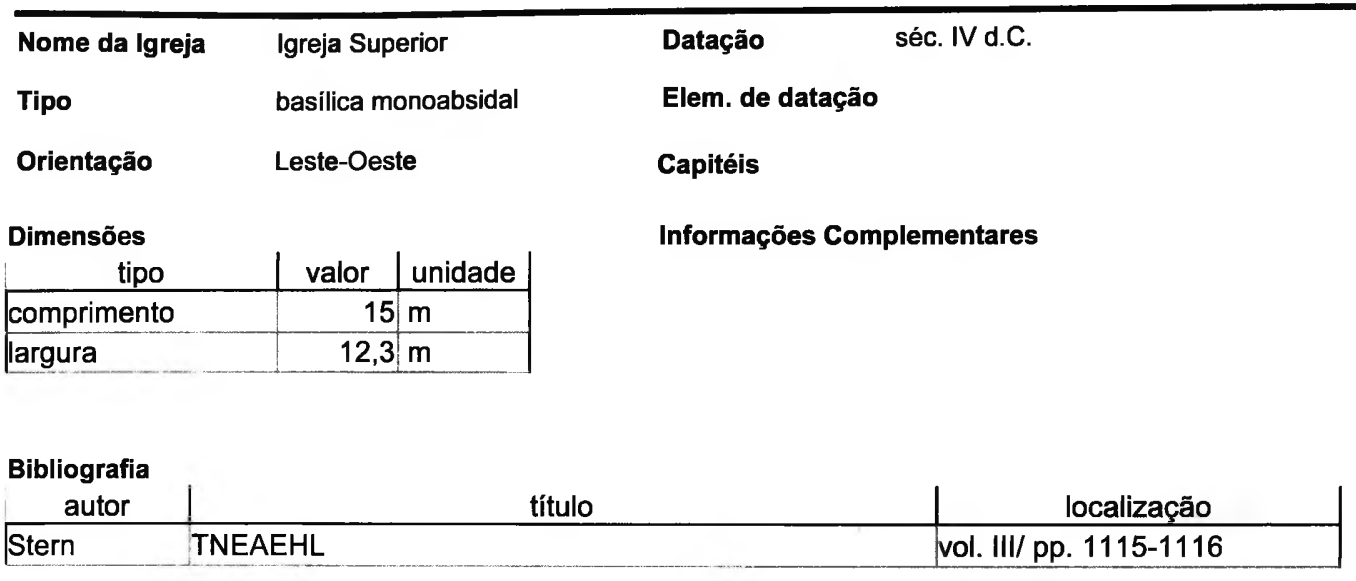

\section{Arquivo}

Ficha LXXIII

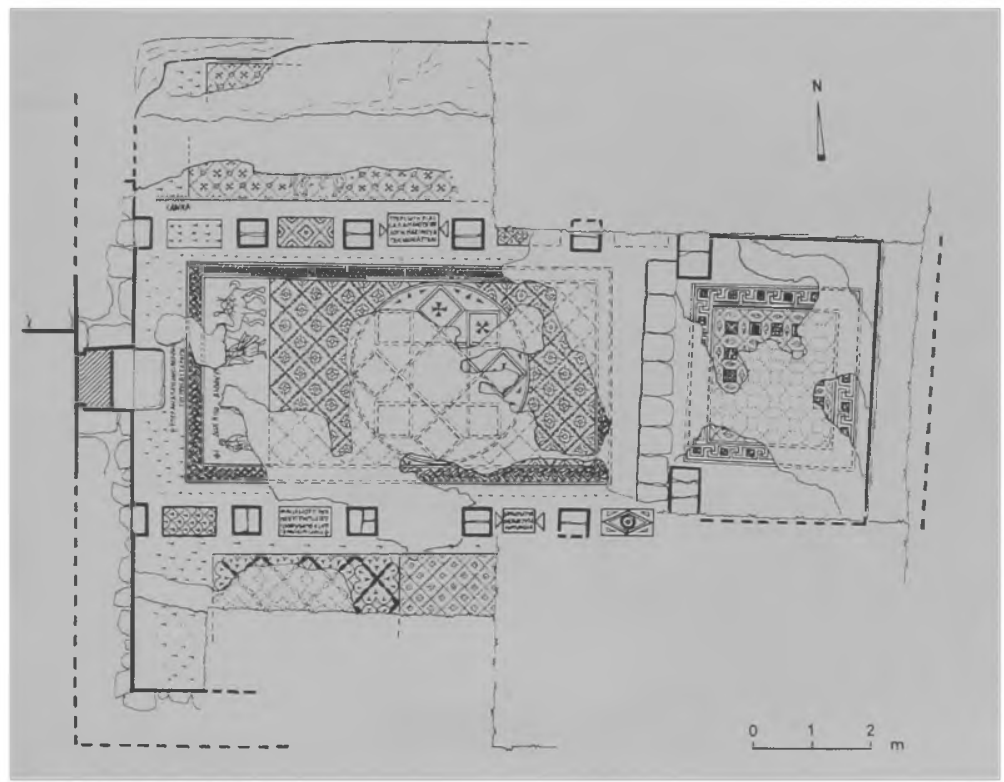

Planta da Igreja Superior

MountNebo05_02.jpg 


\begin{tabular}{|c|c|c|}
\hline Nome da Igreja & Igreja do Diácono Tomas & primeira metade do séc. VI d.C. \\
\hline Tipo & basílica monoabsidal & Elem. de datação \\
\hline Orientação & Leste-Oeste & Capitéis \\
\hline Dimensões & & Informações Complementares \\
\hline tipo & \begin{tabular}{l|l|} 
valor & unidade \\
\end{tabular} & \multirow{3}{*}{$\begin{array}{l}\text { Sua abside tem a forma retangular e é ladeada por } \\
\text { outras duas salas também retangulares. }\end{array}$} \\
\hline comprimento & $14 \mathrm{~m}$ & \\
\hline largura & $10,5 \mathrm{~m}$ & \\
\hline $\begin{array}{c}\text { Bibliografia } \\
\text { autor }\end{array}$ & título & localização \\
\hline Stern & AEHL & vol. III/ pp. 1117-1118 \\
\hline
\end{tabular}

Arquivo

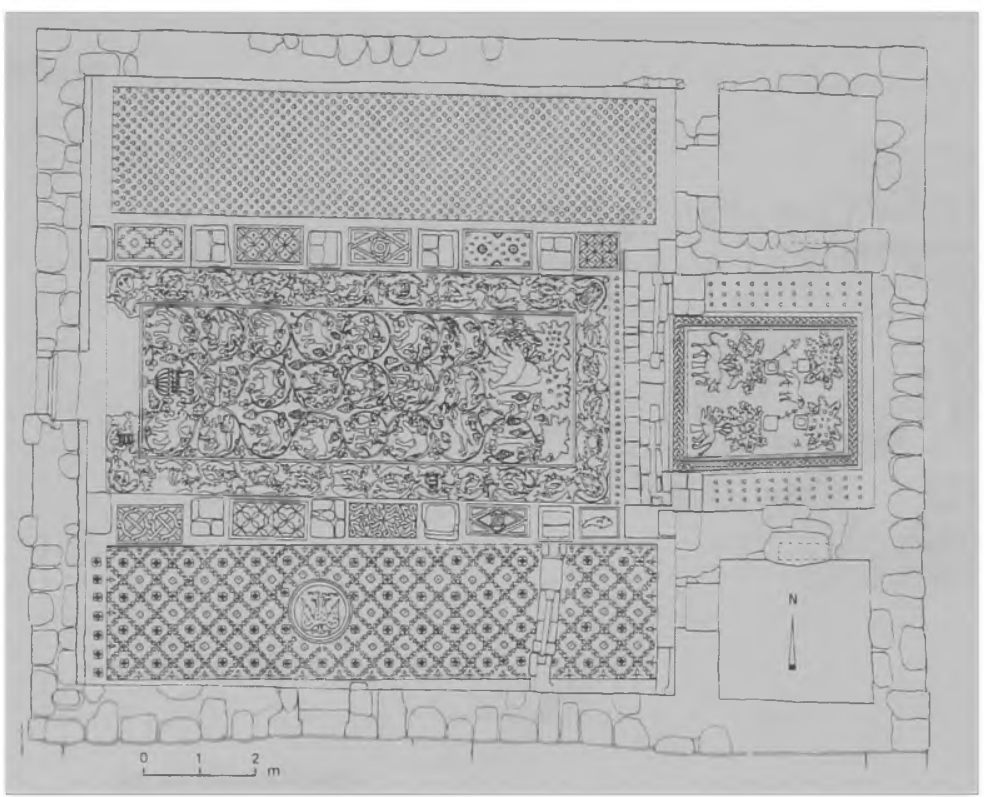

Planta da Igreja do diácono Tomas

MountNebo06_03.jpg 
Local Nahariya

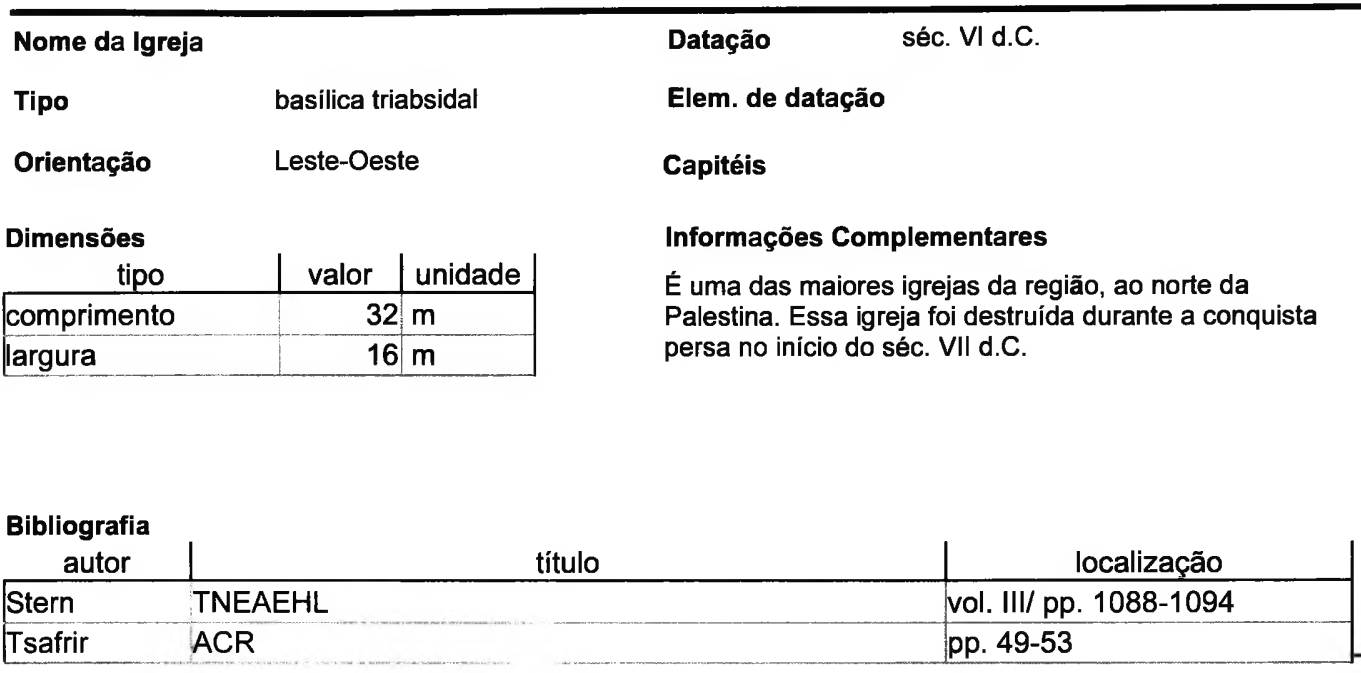

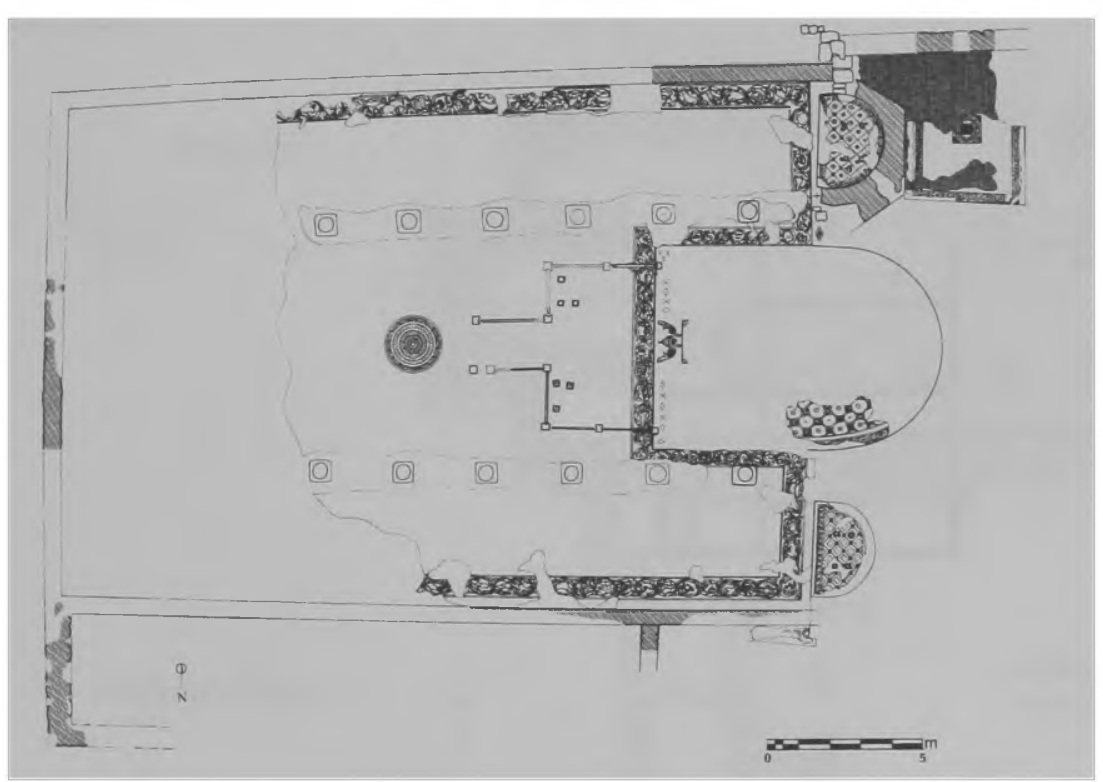

Planta da igreja

Nahariya_02.jpg 
Local Nazareth

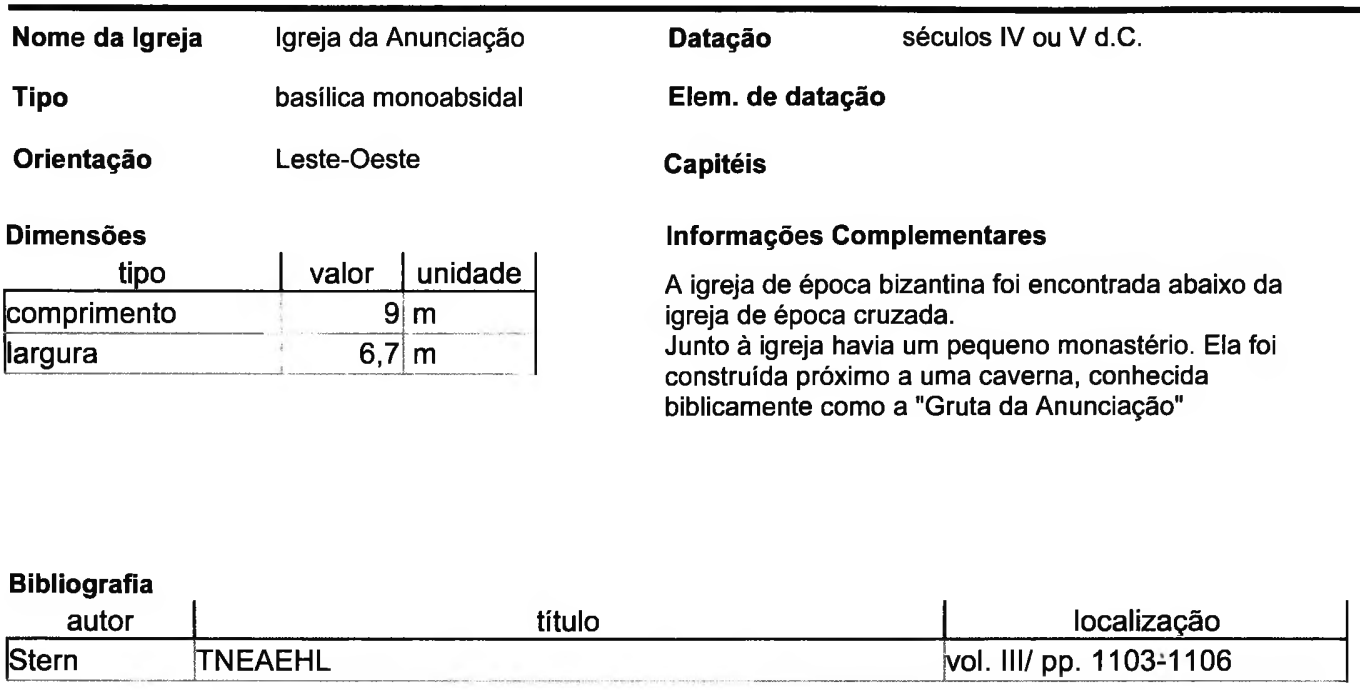

\section{Arquivo}

Ficha LXXVI

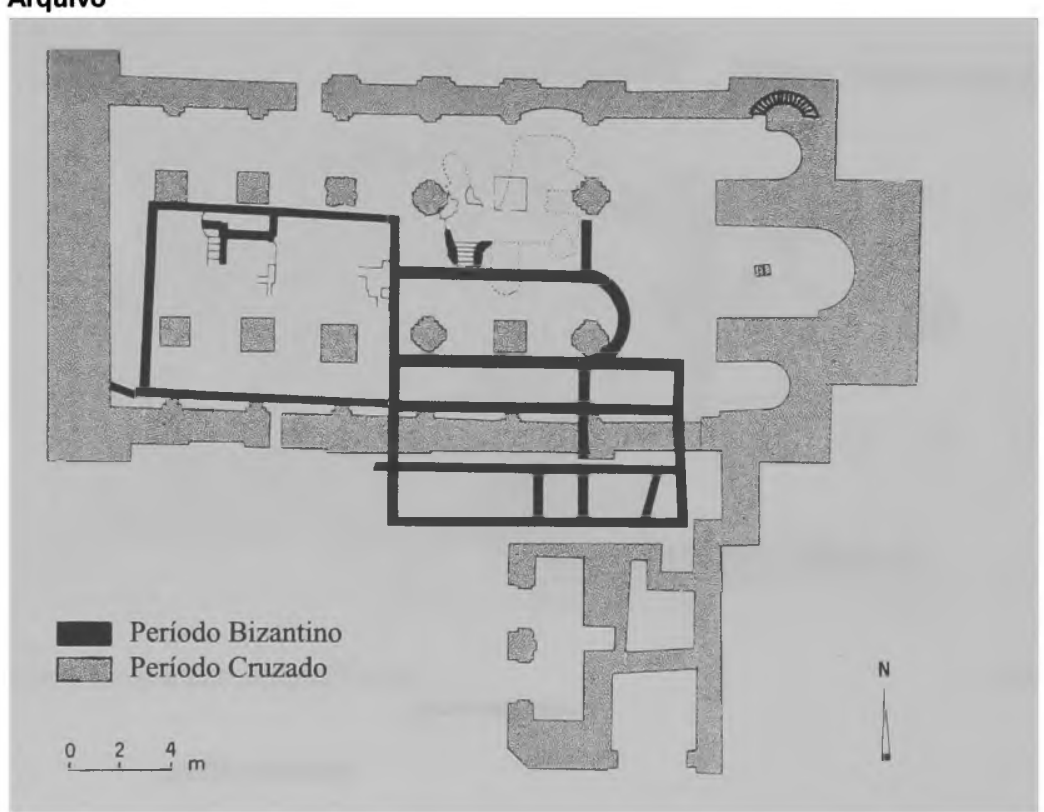

Planta geral da Igreja da Anunciação

Nazareth_01.jpg 
Local Nessana

\begin{tabular}{|c|c|c|}
\hline Nome da Igreja & Igreja Norte & século IV d.C. \\
\hline Tipo & basílica monoabsidal & Elem. de datação \\
\hline Orientação & Leste-Oeste & Capitéis \\
\hline Dimensões & & Informações Complementares \\
\hline tipo & \begin{tabular}{l|l|} 
valor & unidade \\
\end{tabular} & Sua entrada principal está a leste, por causa das \\
\hline comprimento & $\begin{array}{r}19 \mathrm{~m} \\
107 \mathrm{~m}\end{array}$ & $\begin{array}{l}\text { condições geográficas e sua posição em relação à } \\
\text { cidade. }\end{array}$ \\
\hline
\end{tabular}

\begin{tabular}{l|l|l|}
$\begin{array}{c}\text { Bibliografia } \\
\text { autor }\end{array}$ & título & localização \\
\hline Stern & TNEAEHL & vol. III/ p. 1148 \\
\hline
\end{tabular}

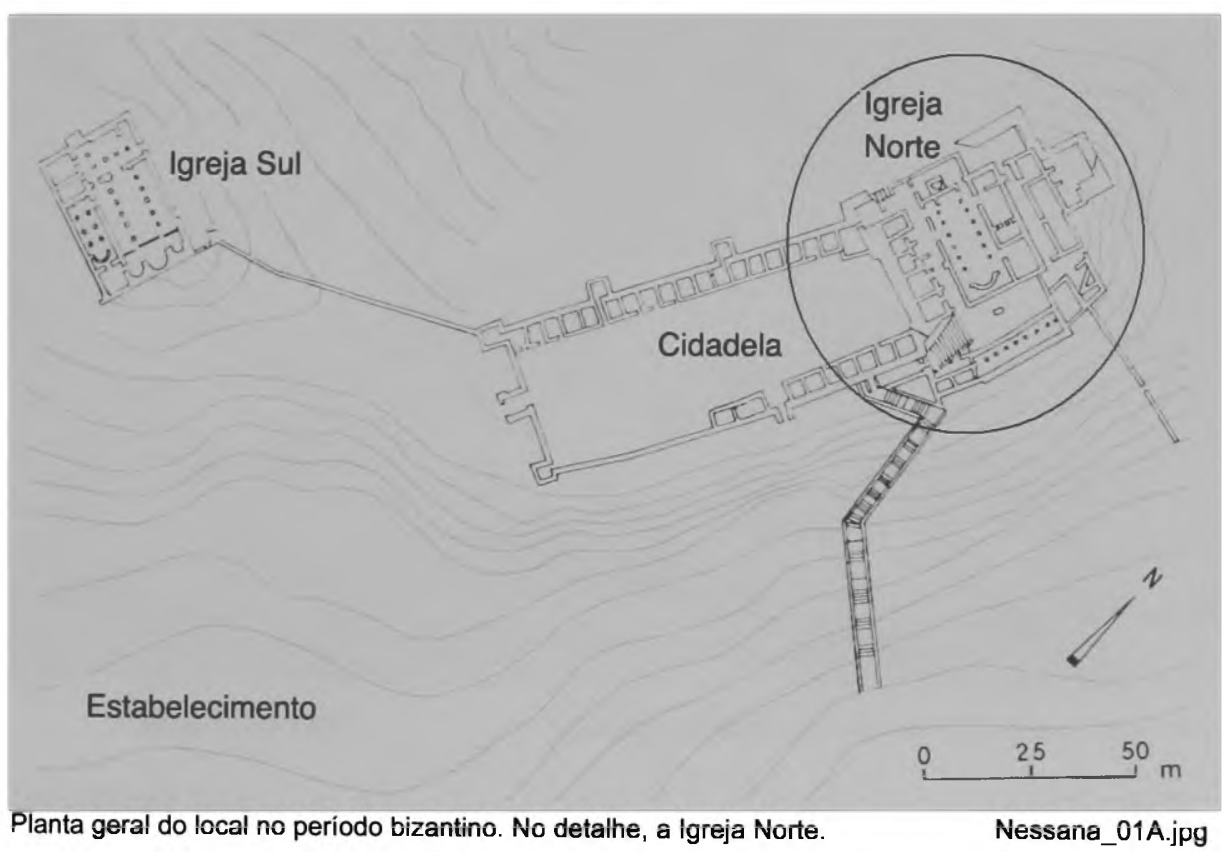




\begin{tabular}{|c|c|c|}
\hline Nome da Igreja & Igreja Sul & século IV d.C. \\
\hline Tipo & basílica triabsidal & Elem. de datação \\
\hline Orientação & Leste-Oeste & Capitéis \\
\hline Dimensões & & Informaçōes Complementares \\
\hline tipo & valor $\quad$ unidade & \multirow{3}{*}{$\begin{array}{l}\text { As } 3 \text { absides da igreja estão inscritas. Essa igreja possui } \\
\text { nártex. }\end{array}$} \\
\hline comprimento & $20,8 \mathrm{~m}$ & \\
\hline largura & $14,1 \mathrm{~m}$ & \\
\hline
\end{tabular}

\begin{tabular}{|c|c|c|}
\hline $\begin{array}{c}\text { Bibliografia } \\
\text { autor }\end{array}$ & título & localização \\
\hline Stern & TNEAEHL & vol. III/ pp. 1148-1149 \\
\hline
\end{tabular}

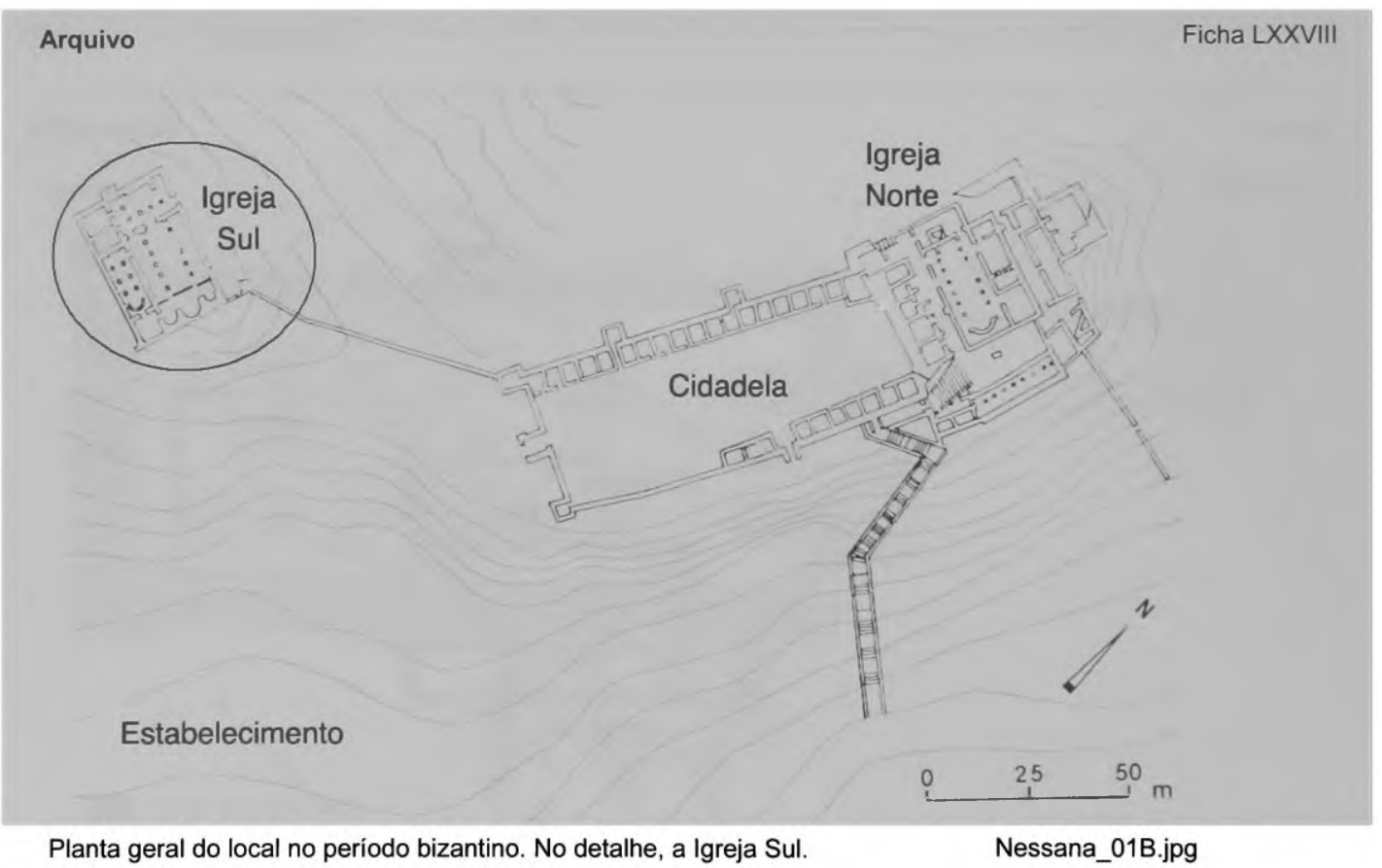


Local

\begin{tabular}{|c|c|c|}
\hline Nome da Igreja & \multicolumn{2}{|c|}{ Igreja Norte } \\
\hline Tipo & \multicolumn{2}{|c|}{ basilica monoabsidal } \\
\hline Orientação & \multicolumn{2}{|c|}{ Leste-Oeste } \\
\hline \multicolumn{3}{|l|}{ Dimensōes } \\
\hline tipo & valor & unidade \\
\hline comprimento & 22,5 & $m$ \\
\hline largura & 14,5 & $\mathrm{~m}$ \\
\hline
\end{tabular}

Datação séculos IV ou V d.C.

\section{Elem. de datação}

\section{Capitéis}

\section{Informaçōes Complementares}

A igreja tem uma sala anexa ao lado norte e várias salas de serviço ao sul da igreja.

\begin{tabular}{|l|c|c|}
$\begin{array}{c}\text { Bibliografia } \\
\text { autor }\end{array}$ & título & localização \\
\hline Stern & TNEAEHL & Ivol. III/ pp. 1162-1163 \\
\hline
\end{tabular}

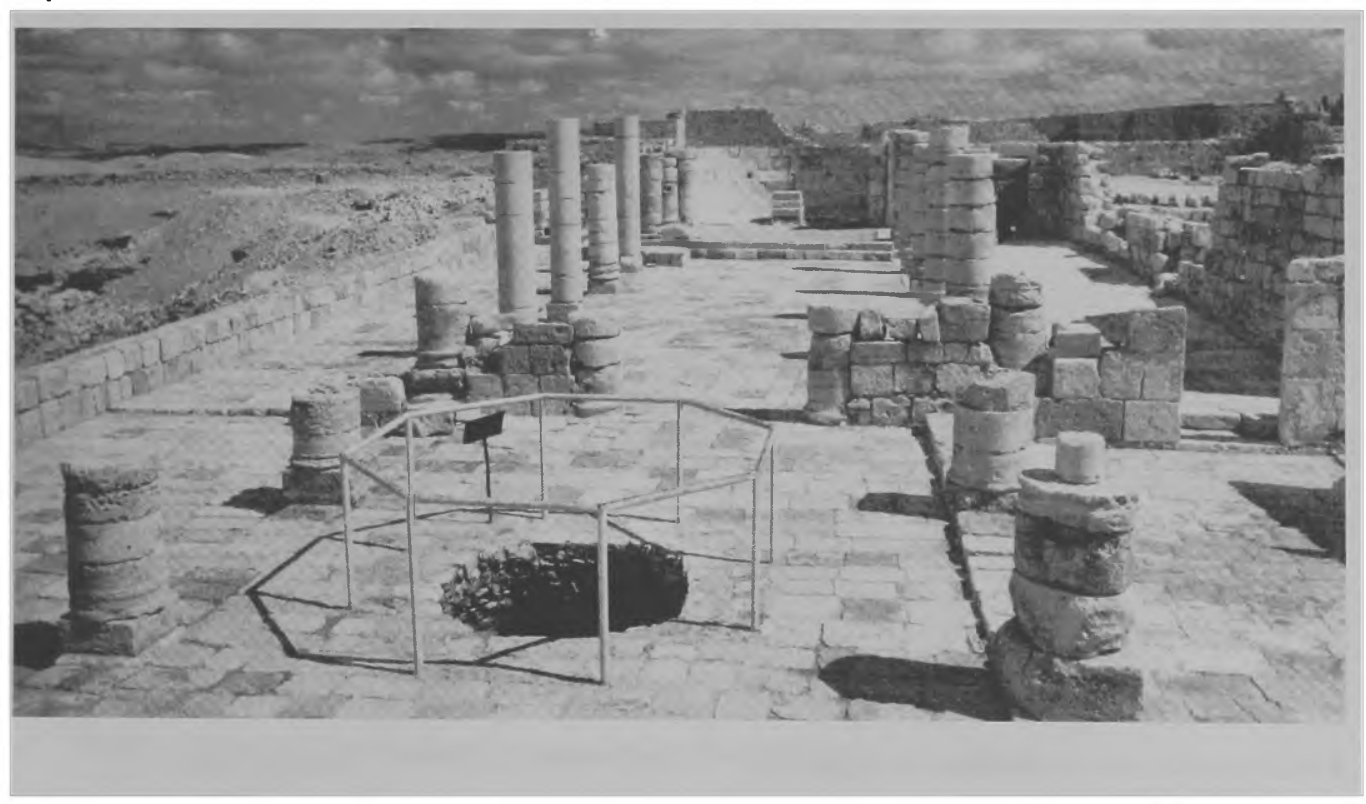

Vista da Igreja Norte

Oboda01_02.jpg 


\begin{tabular}{|c|c|c|}
\hline Nome da Igreja & Igreja Sul & metade do séc. V d.C. \\
\hline Tipo & basilica monoabsidal & Elem. de datação \\
\hline Orientaçāo & Leste-Oeste & Capitéis \\
\hline Dimensões & & Informações Complementares \\
\hline tipo & valor $\quad$ unidade & \multirow{3}{*}{$\begin{array}{l}\text { Também é conhecida como lgreja do Martírio de São } \\
\text { Teodoro. }\end{array}$} \\
\hline comprimento & $25 \mathrm{~m}$ & \\
\hline largura & $14 \mathrm{~m}$ & \\
\hline
\end{tabular}

\begin{tabular}{|l|c|c|}
$\begin{array}{c}\text { Bibliografia } \\
\text { autor }\end{array}$ & titulo & \multicolumn{1}{c|}{ localização } \\
\hline Stern & TNEAEHL & vol. III/ p. 1163 \\
\hline
\end{tabular}

\section{Arquivo}

Ficha $L X X X$

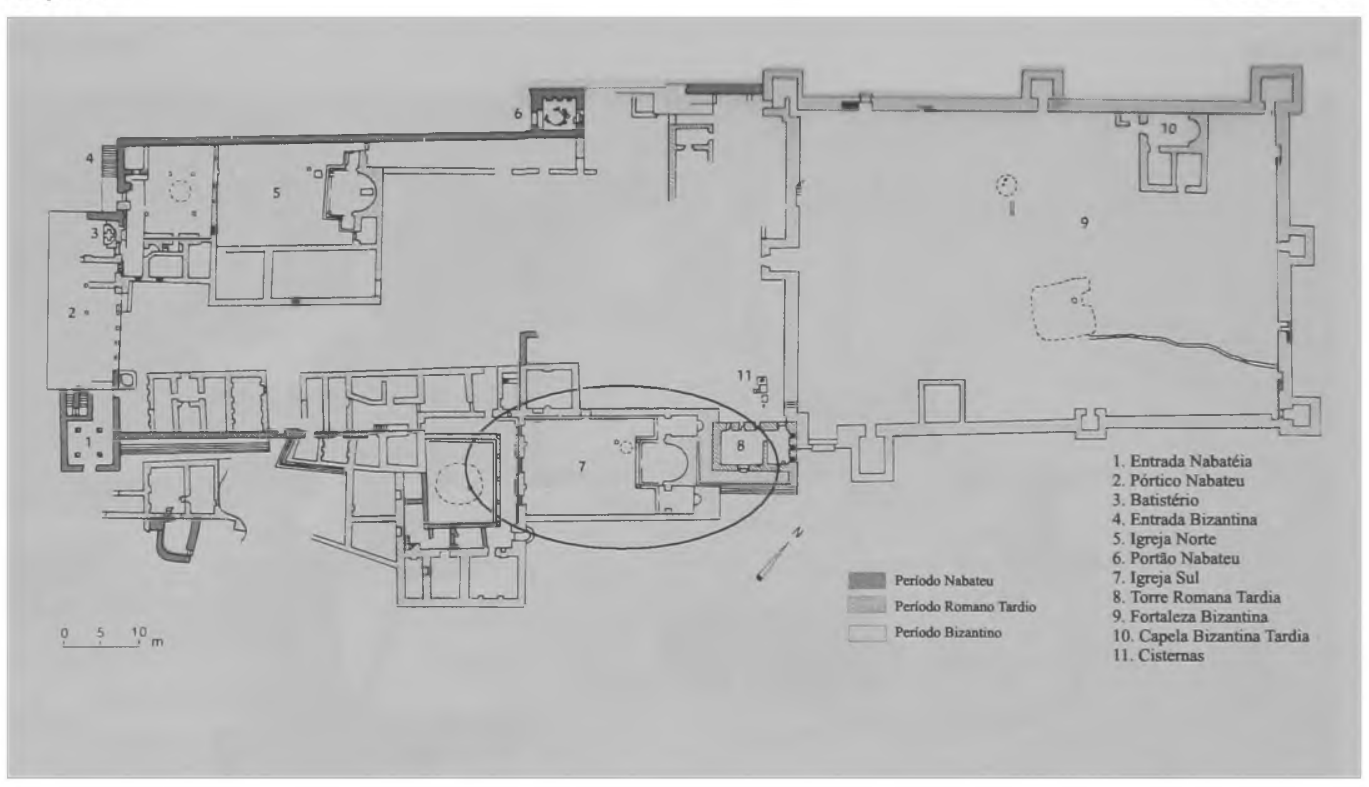

Planta geral da acrópole. No detalhe, a Igreja Sul

Oboda_03.jpg 


\begin{tabular}{|c|c|c|}
\hline \multicolumn{3}{|c|}{ Nome da Igreja } \\
\hline Tipo & \multicolumn{2}{|c|}{ basilica monoabsidal } \\
\hline Orientação & \multicolumn{2}{|c|}{ Leste-Oeste } \\
\hline Dimensões & & \\
\hline tipo & valor & unidade \\
\hline comprimento & \multicolumn{2}{|c|}{$33 \mathrm{~m}$} \\
\hline largura & \multicolumn{2}{|c|}{$20 \mathrm{~m}$} \\
\hline
\end{tabular}

Datação

séc. V d.C.

\section{Elem. de datação}

\section{Capitéis}

\section{Informações Complementares}

A igreja tem uma abside inscrita, ladeada por duas salas. Tem também um átrio. Essa igreja foi construída durante o apogeu do estabelecimento de época bizantina em Ostrakine e foi destruida no séc. VII d.C.

\section{Bibliografia}

\begin{tabular}{|l|l|l|}
\multicolumn{1}{c|}{$\begin{array}{c}\text { autor } \\
\text { Stern }\end{array}$} & título & \multicolumn{1}{c|}{ localização } \\
\hline Tsafrir & ACR & vol. III/ pp. 1171-1173 \\
\hline
\end{tabular}

\section{Arquivo}

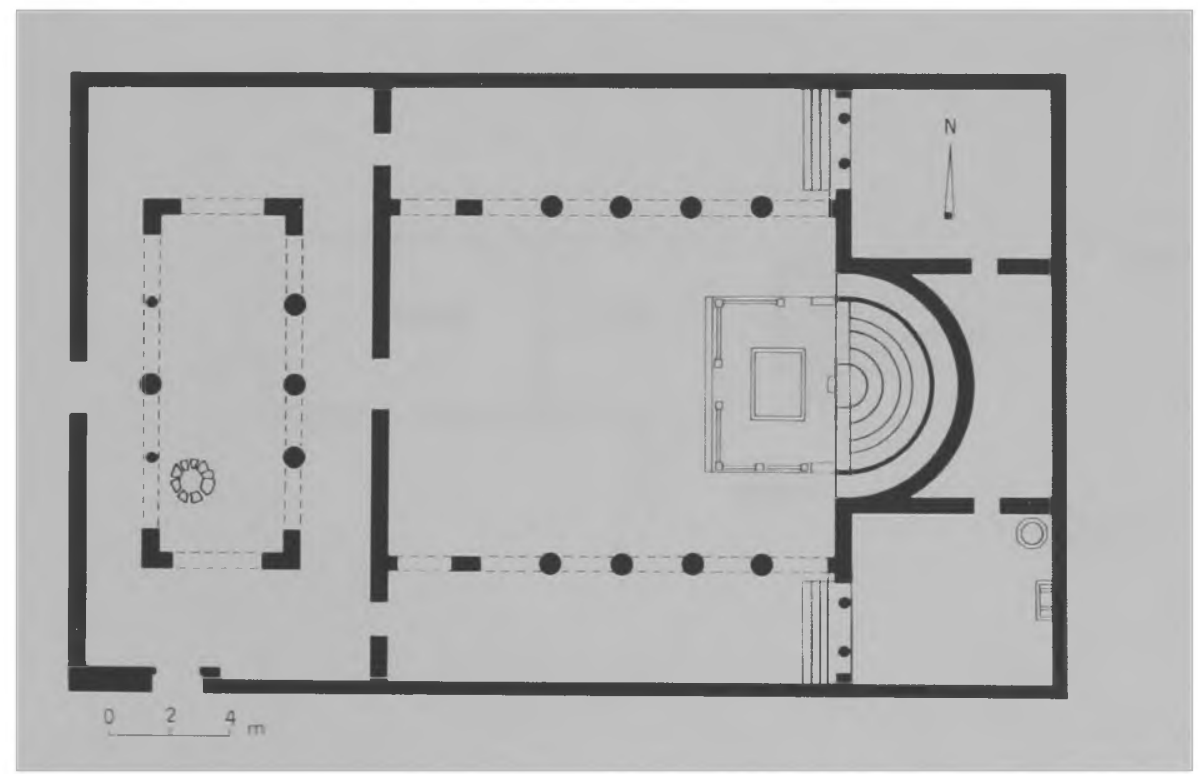

Planta da igreja

Ostrakine_02.jpg 


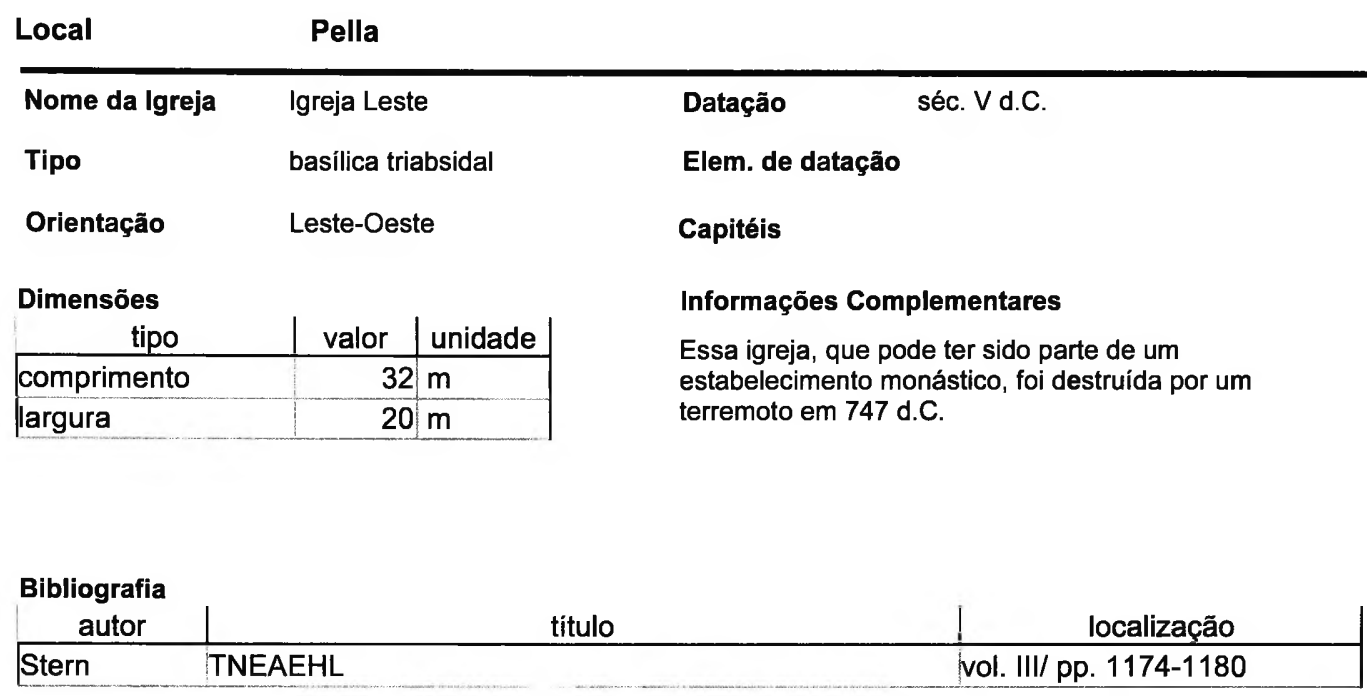

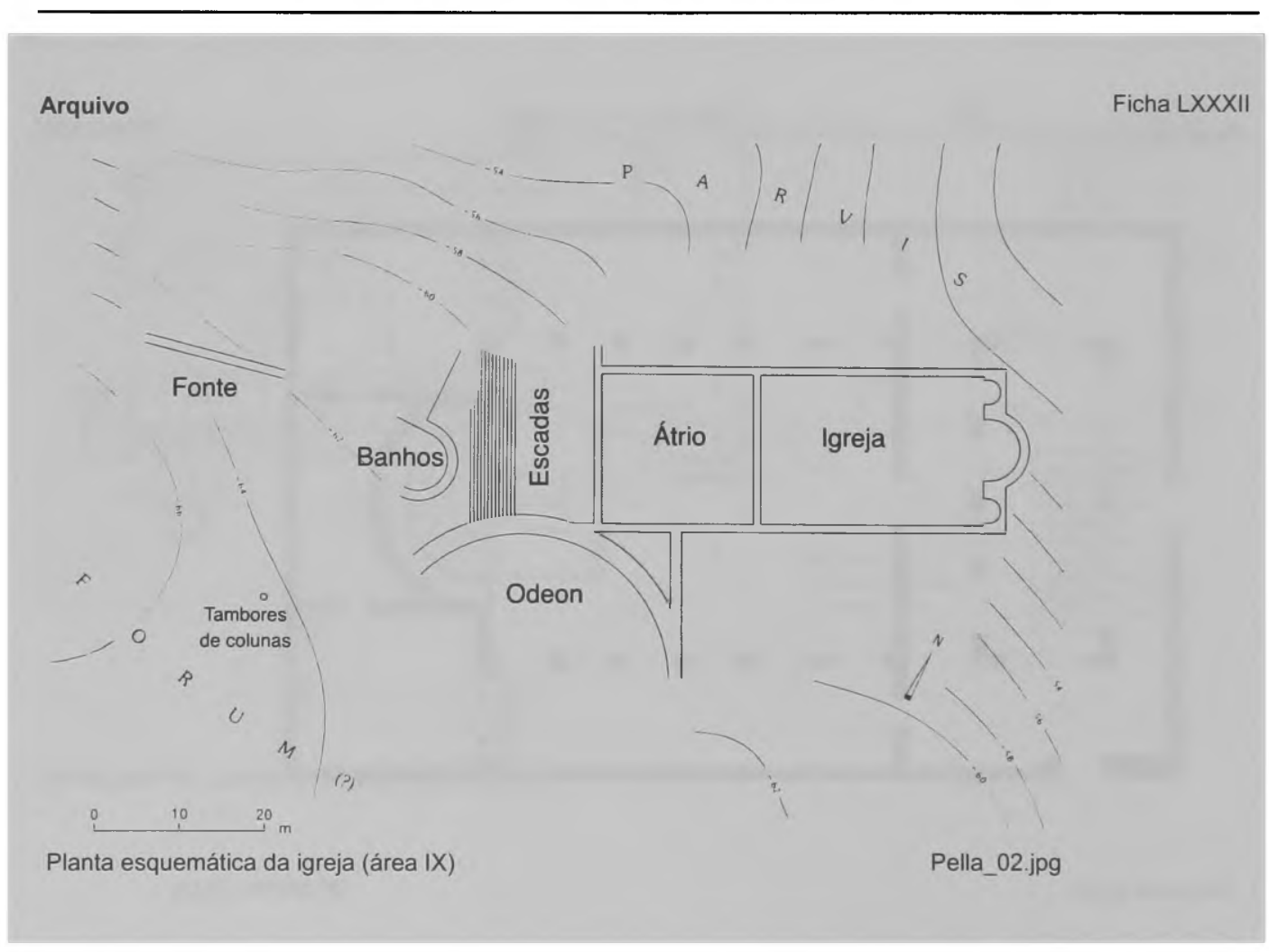




\begin{tabular}{lll}
\hline $\begin{array}{l}\text { Nome da Igreja } \\
\text { Tipo }\end{array}$ & $\begin{array}{l}\text { Igreja do Complexo Cívico } \\
\text { basilica triabsidal }\end{array}$ & $\begin{array}{l}\text { Datação } \\
\text { Elem. de datação }\end{array}$ \\
Orientação & Leste-Oeste & Capitéis \\
Dimensōes & Informaçōes Complementares \\
& $\begin{array}{l}\text { Essa igreja, que provavelmente foi a catedral da cidade, } \\
\text { foi escavada em uma área onde foram encontrados } \\
\text { vários edificios, conhecida como Complexo Civico. As } 3 \\
\text { absides da igreja foram acrescentadas na sua } \\
\text { extremidade leste no séc. VI d.C. }\end{array}$
\end{tabular}

\begin{tabular}{|l|c|c|}
$\begin{array}{c}\text { Bibliografia } \\
\text { autor }\end{array}$ & título & localização \\
\hline Stern & TNEAEHL & vol. III/ pp. 1174-1180 \\
\hline
\end{tabular}

Arquivo

Ficha LXXXIII 


\section{Local Rabbath Ammon}

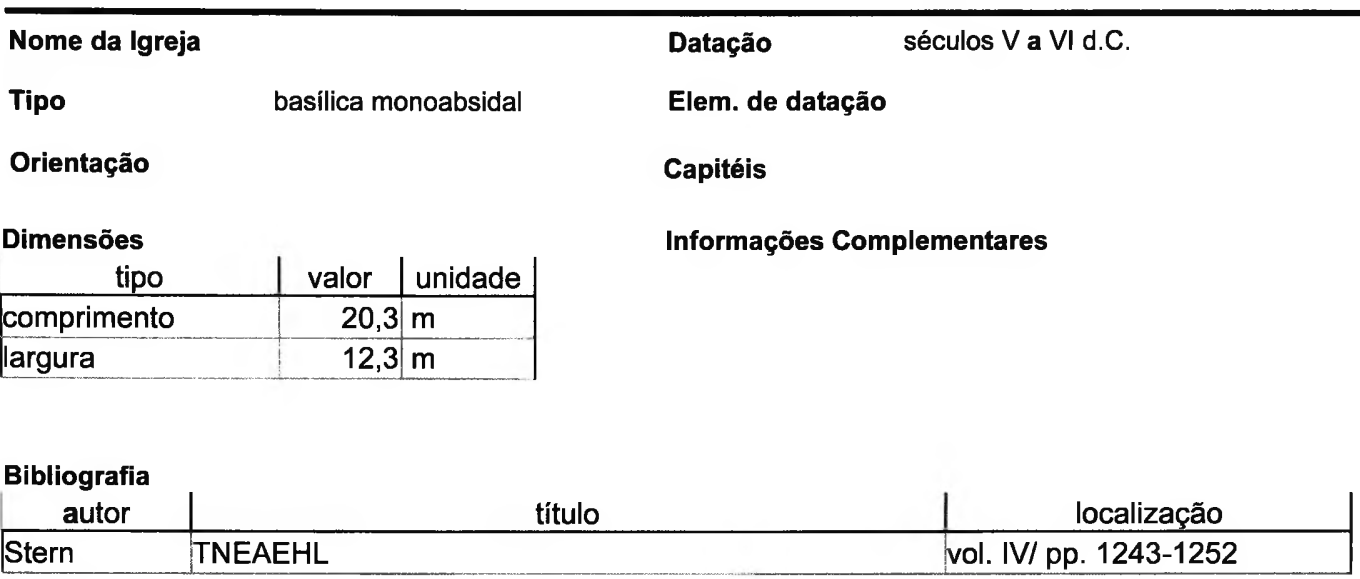

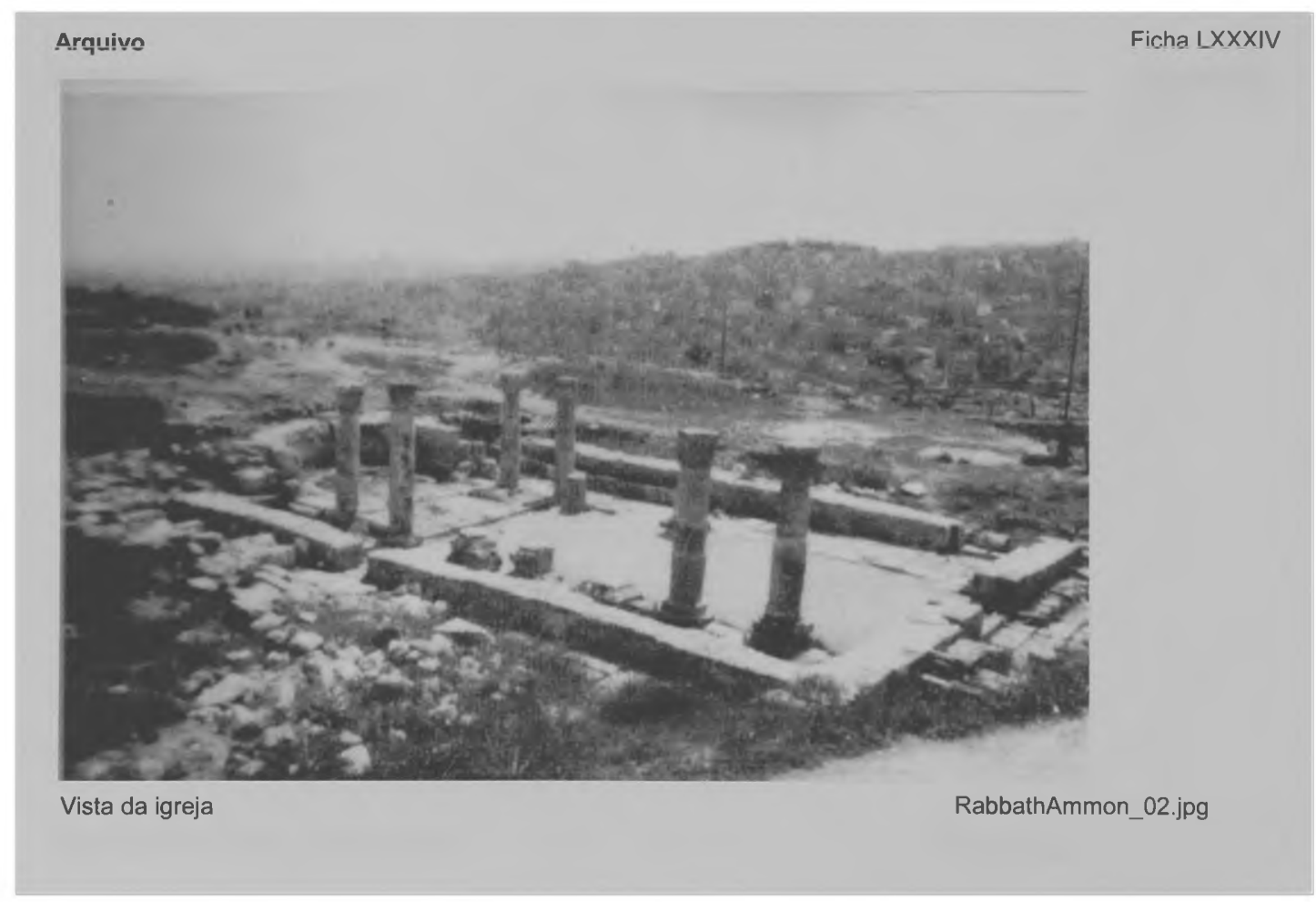


Local

\section{Nome da Igreja}

Tipo

Orientação

Dimensões

\section{Ramat Rahel}

Igreja de Kathisma

Datação

445 d.C.

Elem. de datação

\section{Capitéis}

\section{Informações Complementares}

Tem uma fileira adicional de colunas no lado oeste, que aparentemente faz parte do nártex.

\begin{tabular}{|c|c|c|}
$\begin{array}{c}\text { Bibliografia } \\
\text { autor }\end{array}$ & título & localização \\
\hline Stern & TNEAEHL & vol. IV/ pp. 1261-1267 \\
\hline
\end{tabular}

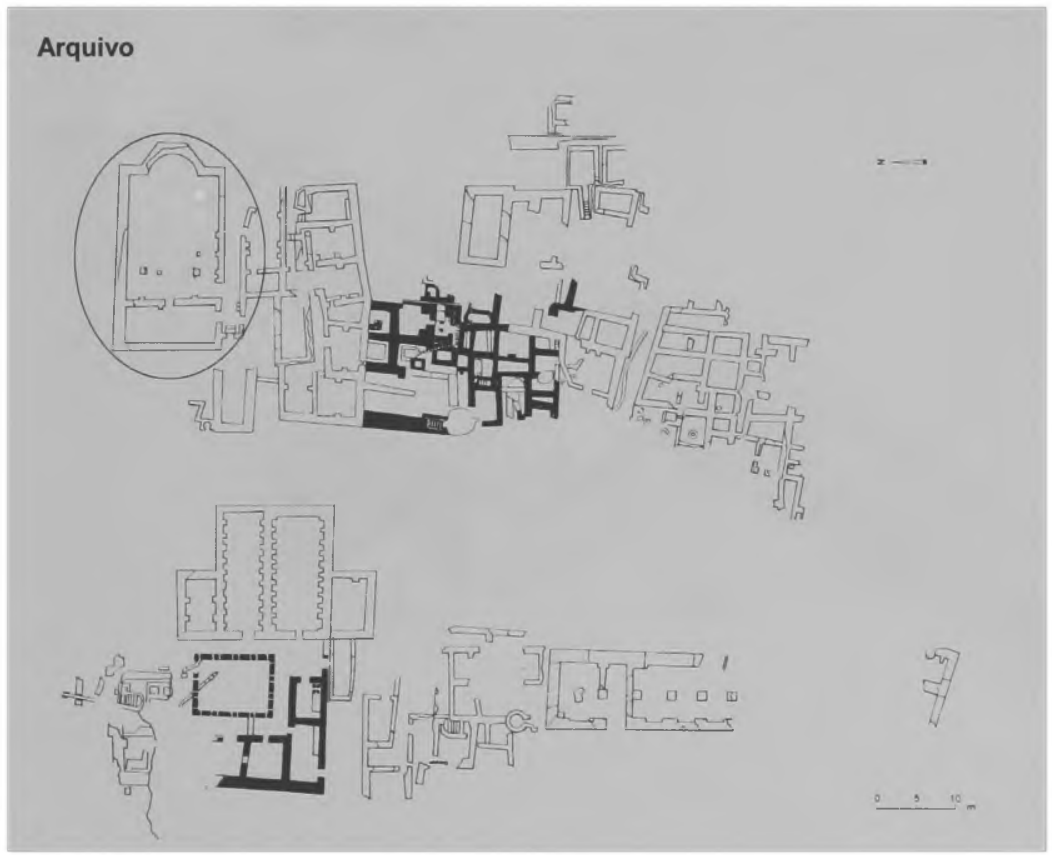

Ficha LXXXV

Pianta dos restos romano e bizantino: 1) Villa romano-bizantina; 2) Depósitos de época bizantina; 3) Banho romano-bizantino; 4) A Igreja de RamatRahel_01.jpg Kathisma. 
Local Rehovot-in-the-Negev

\begin{tabular}{|c|c|c|}
\hline Nome da Igreja & Igreja Central & 550 a 551 d.C. \\
\hline Tipo & basilica monoabsidal & Elem. de datação inscrição no piso de mármore \\
\hline Orientação & Leste-Oeste & Capitéis \\
\hline Dimensões & & Informações Complementares \\
\hline tipo & valor unidade & A jareia está localizada no coracão da área construída da \\
\hline comprimento & $20 \mathrm{~m}$ & cidade. \\
\hline largura & $16,3 \mathrm{~m}$ & $\begin{array}{l}\text { Somente a parte leste da igreja foi escavada, revelando } \\
\text { a abside, duas salas ao seu lado e parte das naves } \\
\text { central e laterais. }\end{array}$ \\
\hline
\end{tabular}

\begin{tabular}{|c|c|c|}
\hline $\begin{array}{c}\text { Bibliografia } \\
\text { autor }\end{array}$ & título & localização \\
\hline Stern & TNEAEHL & vol. IV/ pp. 1274-1277 \\
\hline Tsafrir & ACR & pp. 294-302 \\
\hline
\end{tabular}

Arquivo

Ficha $L X X X V \mid$ 


\begin{tabular}{|c|c|c|}
\hline Nome da Igreja & \multicolumn{2}{|c|}{ Igreja Norte } \\
\hline Tipo & \multicolumn{2}{|c|}{ basílica triabsidal } \\
\hline Orientação & \multicolumn{2}{|c|}{ Leste-Oeste } \\
\hline Dimensões & & \\
\hline tipo & valor & unidade \\
\hline comprimento & \multicolumn{2}{|c|}{$25 \mathrm{~m}$} \\
\hline largura & \multicolumn{2}{|c|}{$14 \mathrm{~m}$} \\
\hline
\end{tabular}

Datação

$460-470$ d.C

Elem. de datação inscrições em Grego

\section{Capitéis}

\section{Informações Complementares}

Essa igreja, juntamente com o seu átrio, formam um dos maiores complexos de igreja conhecidos na região do Negev. A igreja tem uma cripta abaixo da abside central. Foi construída uma capela na face norte da igreja.

\begin{tabular}{|c|c|c|}
\hline $\begin{array}{c}\text { Bibliografia } \\
\text { autor }\end{array}$ & título & localização \\
\hline Stern & TNEAEHL & vol. IV/ pp. 1274-1277 \\
\hline Tsafrir & ACR & pp. $294-302$ \\
\hline
\end{tabular}

Arquivo

Ficha LXXXVII

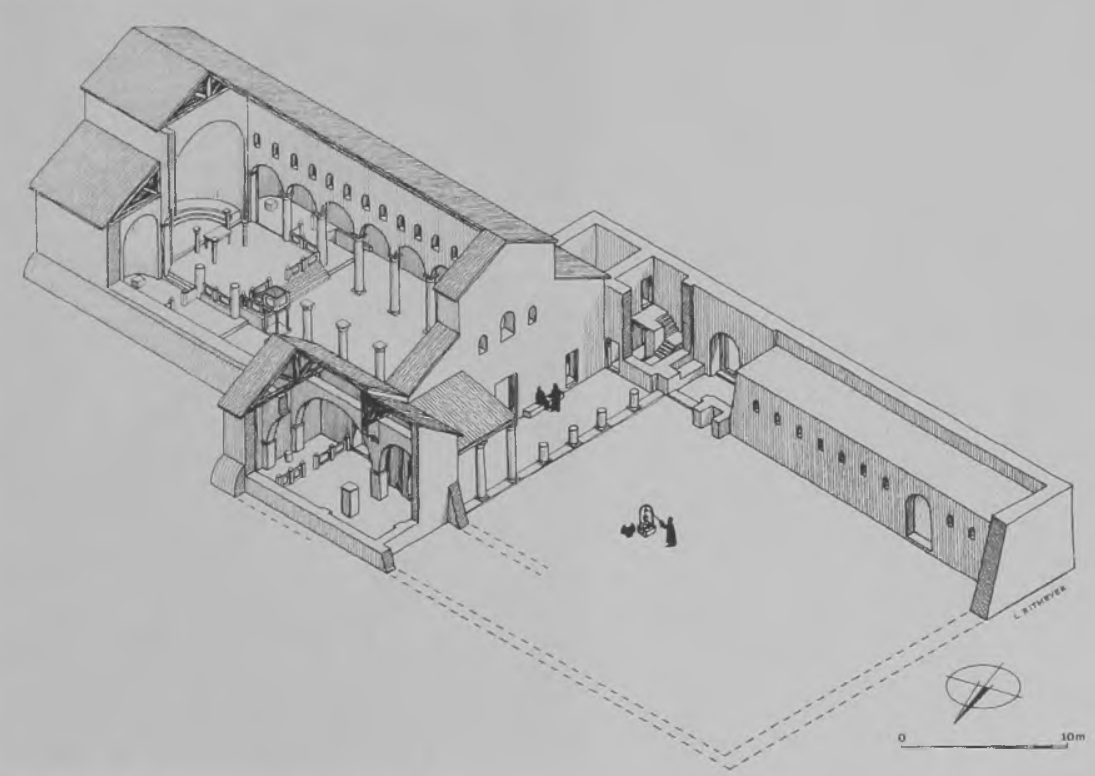




\section{Local Roglit}

Nome da Igreja
Tipo
Orientação
\begin{tabular}{l|r|r|} 
basilica \\
Dimensões \\
tipo & valor & unidade \\
\hline Comprimento & 14 & $\mathrm{~m}$ \\
\hline largura & 10,7 & $\mathrm{~m}$ \\
\hline
\end{tabular}

séc. V d.C.

Elem. de datação

Capitéis coríntios

\section{Informações Complementares}

A abside da igreja não foi escavada.

As partes descobertas desse edifício revelaram um nártex trapezoidal.

Duas fileiras de três colunas separam a nave central das naves laterais.

\section{Bibliografia}

\begin{tabular}{|l|l|l|}
\multicolumn{1}{c|}{ autor } & \multicolumn{1}{c|}{ título } & \multicolumn{1}{c|}{ localização } \\
\hline Stern & TNEAEHL & vol. 1/ p. 312 \\
\hline
\end{tabular}

\section{Arquivo}

Ficha $L X X X V I I I$ 
Local Shavei Zion

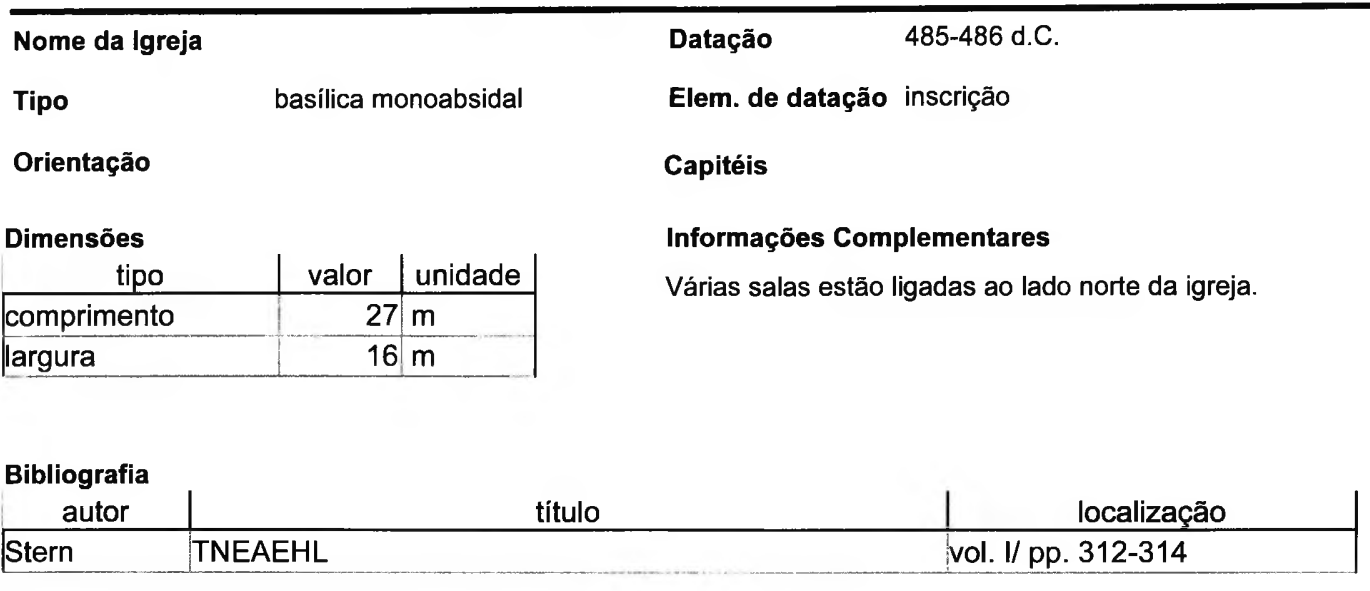

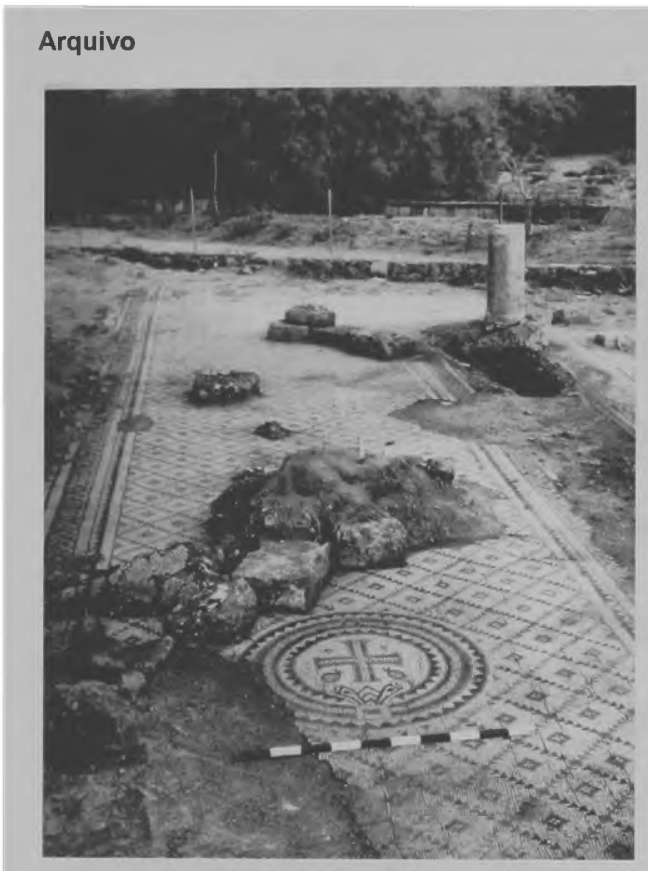

Piso em mosaico na nave lateral norte da igreja 


\section{Local Shepherd's Field}

Nome da lgreja lgreja dos Pastores Datação séc. VI d.C.

Tipo basilica monoabsidal Elem. de datação

Orientação Oeste-Leste Capitéis

\section{Dimensões}

\begin{tabular}{|l|r|l|}
\multicolumn{1}{|c|}{ tipo } & valor & unidade \\
\hline Comprimento & 20,5 & $\mathrm{~m}$ \\
\hline largura & $13,3 \mathrm{~m}$ \\
\hline
\end{tabular}

\section{Informações Complementares}

De acordo com a tradição cristã foi nesse local que um anjo anunciou aos pastores o nascimento de Jesus. Os achados mais antigos datam do séc. IV d.C., e indicam que uma gruta pavimentada com mosaicos existiu nesse lugar. No séc. $V$ d.C. a gruta foi alargada, e sobre ela se estabeleceu posteriormente a igreja.

\section{Bibliografia}

\begin{tabular}{|l|l|l|}
\multicolumn{1}{c|}{ autor } & \multicolumn{1}{c|}{ título } & \multicolumn{1}{c|}{ localização } \\
\hline Stern & TNEAEHL & vol. IV/ pp. 1362-1363 \\
\hline Tsafrir & ACR & pp. 204-206 \\
\hline
\end{tabular}

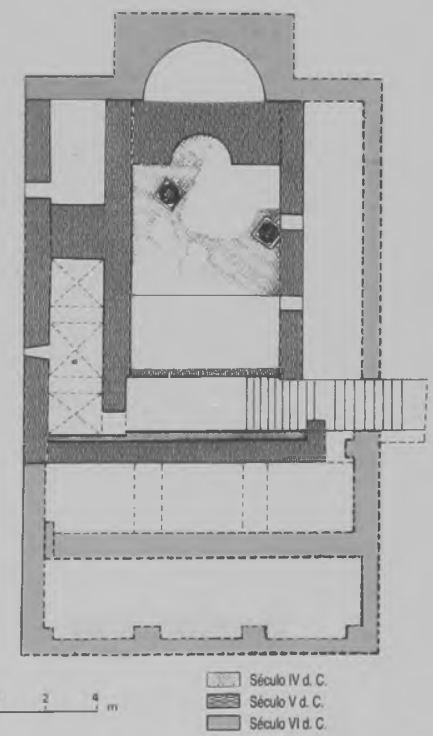

Planta da igreja nos séculos IV a VI (esquerda); e no séc. VII (direita)

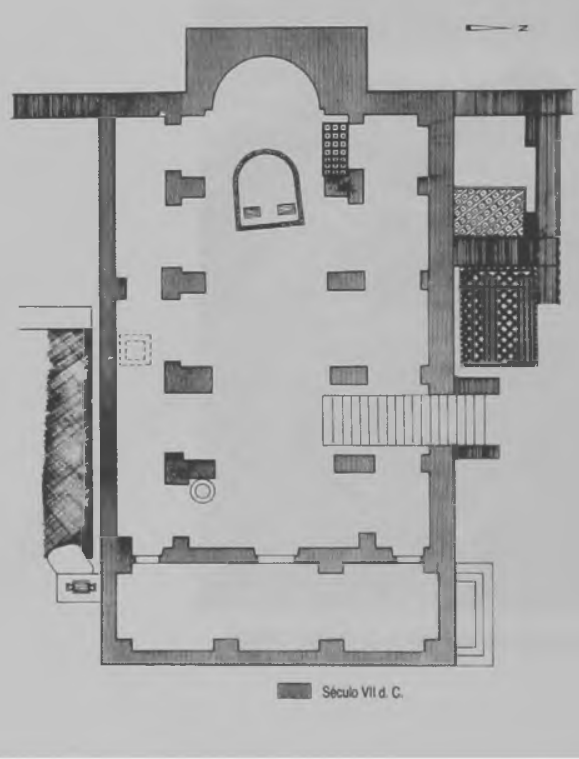

ShepherdsField_02.jpg 
Local Shiloh

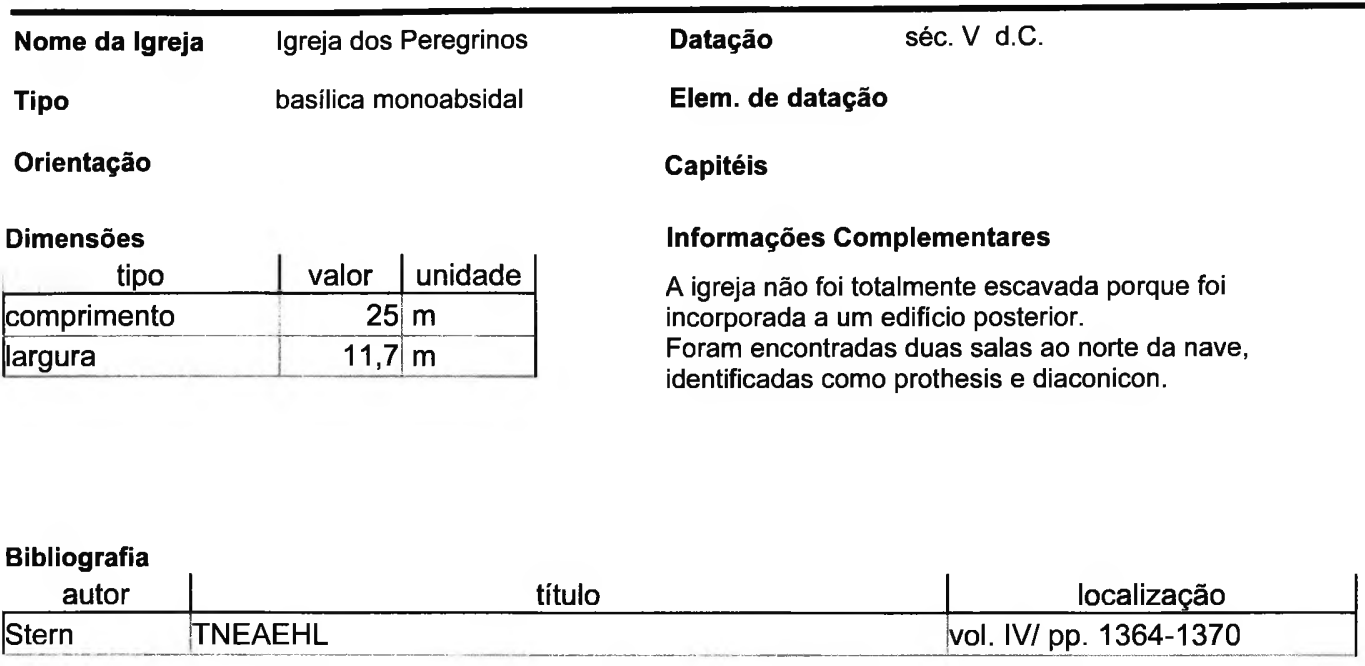

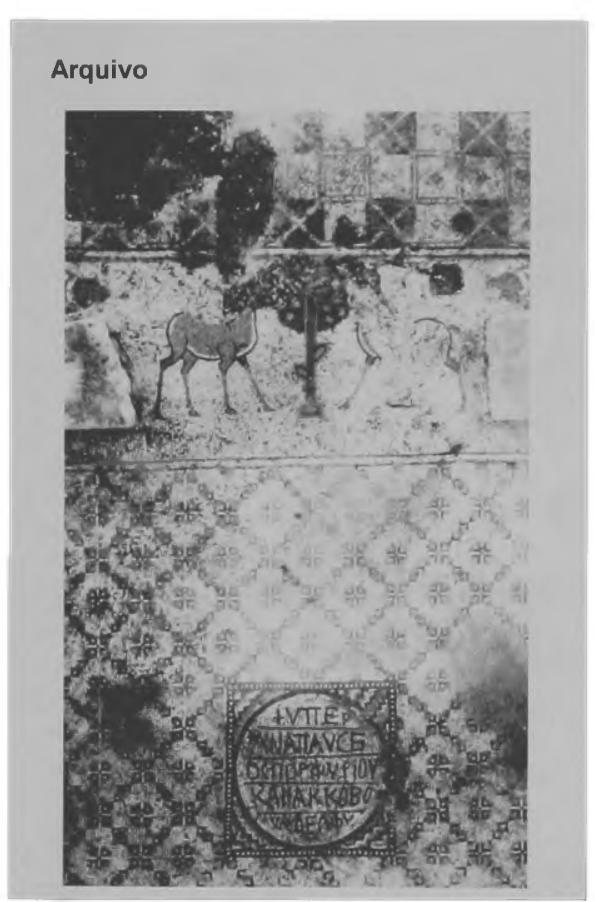

Ficha $\mathrm{XCl}$

Piso em mosaico no prothesis, executado no periodo bizantino 


\begin{tabular}{|c|c|c|}
\hline $\begin{array}{l}\text { Nome da Igreja } \\
\text { Tipo }\end{array}$ & $\begin{array}{l}\text { Basilica } \\
\text { basilica }\end{array}$ & \\
\hline Orientação & & \\
\hline $\begin{array}{r}\text { Dimensões } \\
\text { tipo }\end{array}$ & valor & unidade \\
\hline comprimento & 18 & $m$ \\
\hline largura & 15,1 & $m$ \\
\hline
\end{tabular}

Datação séc. VI d.C.

Elem. de datação

\section{Capitéis}

\section{Informaçōes Complementares}

Este è um caso de uma basílica (civil) que também serviu como igreja.

Além da nave central e das duas naves laterais, a igreja tem um nártex.

Bibliografia

\begin{tabular}{|l|l|l|}
\multicolumn{1}{c|}{$\begin{array}{c}\text { autor } \\
\text { Stern }\end{array}$} & título & localização \\
\hline
\end{tabular}


Local Sinai

\begin{tabular}{|c|c|c|}
\hline Nome da Igreja & \multicolumn{2}{|c|}{ Igreja de Santa Catari } \\
\hline Tipo & \multicolumn{2}{|c|}{ basilica monoabsidal } \\
\hline Orientação & \multicolumn{2}{|c|}{ Leste-Oeste } \\
\hline Dimensões & & \\
\hline tipo & valor & unidade \\
\hline comprimento & \multicolumn{2}{|c|}{$25 \mathrm{~m}$} \\
\hline largura & & $m$ \\
\hline
\end{tabular}

séc. VI d.C.

\section{Elem. de datação}

\section{Capitéis}

\section{Informações Complementares}

A igreja faz parte do Monastério de Santa Catarina.

\section{Bibliografia}

autor

Tsafrir título ocalização

pp. $315-350$

\section{Arquivo}

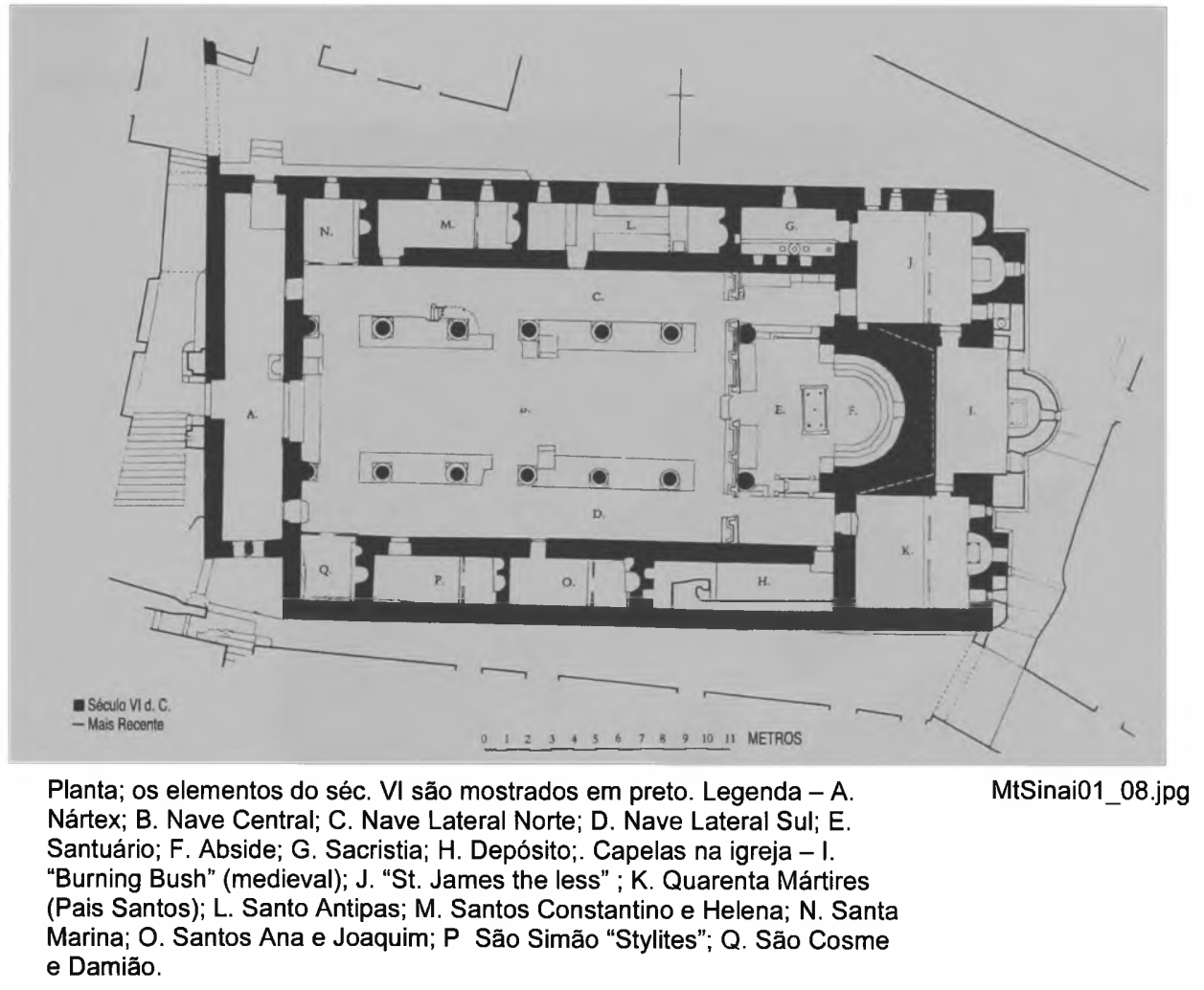




\section{Local Sobata}

\begin{tabular}{llll}
\hline Nome da Igreja & Igreja Sul & Datação & segunda metade do séc. IV d.C. \\
Tipo & basílica monoabsidal & Elem. de datação
\end{tabular}

\section{Orientação}

\section{Dimensões}

\begin{tabular}{|l|r|l|}
\multicolumn{1}{|c|}{ tipo } & valor & unidade \\
\hline Comprimento & 17,6 & $\mathrm{~m}$ \\
\hline largura & 18,2 & $\mathrm{~m}$ \\
\hline
\end{tabular}

\section{Capitéis}

\section{Informações Complementares}

Foi construida sobre dois reservatórios e, por falta de espaço, não tinha átrio, mas tinha nártex.

A planta da igreja era quase quadrada, e a nave central era separada das naves laterais por duas fileiras com 6 colunas.

\begin{tabular}{|l|cc|}
$\begin{array}{c}\text { Bibliografia } \\
\text { autor }\end{array}$ & título & localização \\
\hline Stern & TNEAEHL & vol. IV/ pp.1406-1407 \\
\hline
\end{tabular}

\section{Arquivo}

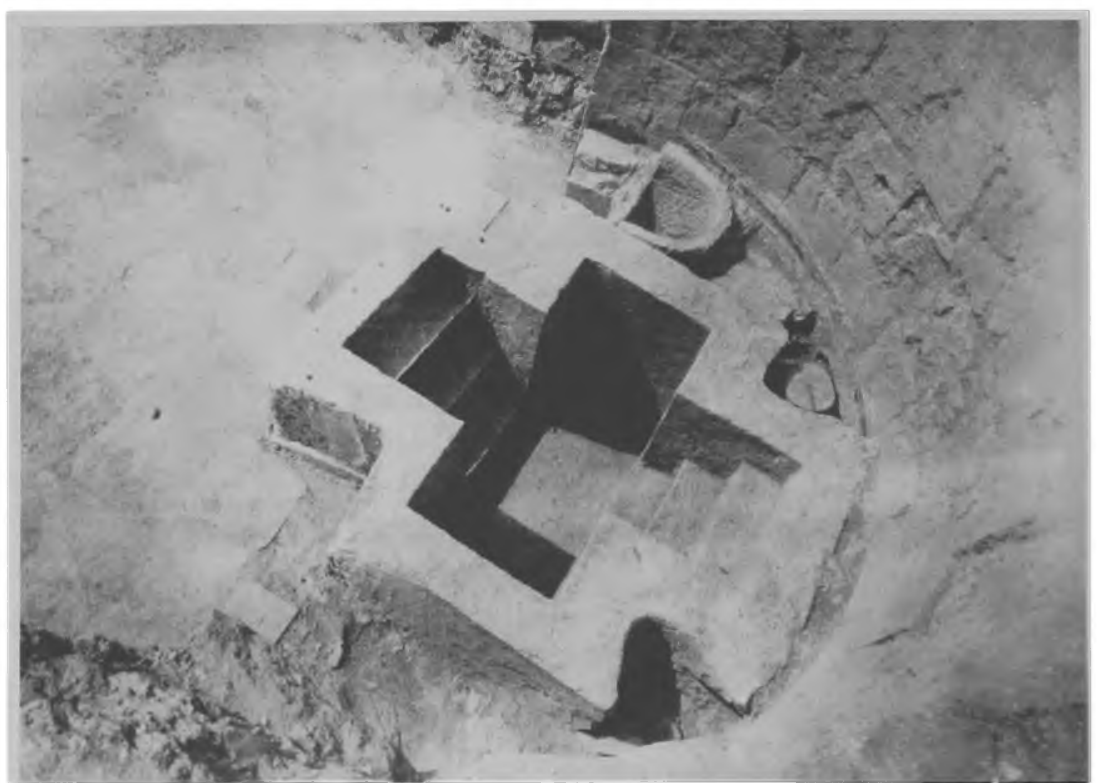

Batistério na Igreja Sul

Sobata01_01.jpg 


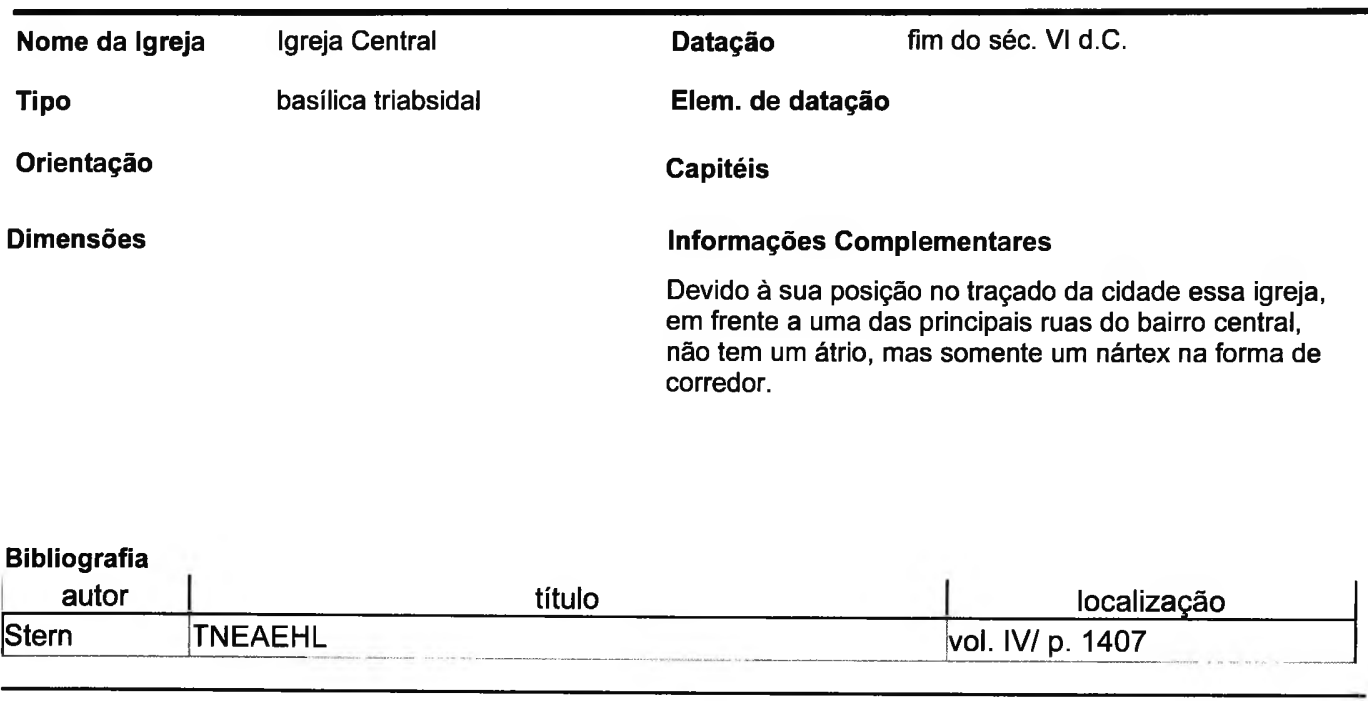

\section{Arquivo}

Ficha XCV 


\begin{tabular}{|c|c|c|}
\hline Nome da Igreja & \multicolumn{2}{|c|}{ Igreja Norte } \\
\hline Tipo & \multicolumn{2}{|c|}{ basilica triabsidal } \\
\hline Orientação & \multicolumn{2}{|c|}{ Leste-Oeste } \\
\hline \multicolumn{3}{|l|}{ Dimensões } \\
\hline tipo & valor & unidade \\
\hline comprimento & 20 & $\mathrm{~m}$ \\
\hline largura & 13 & $m$ \\
\hline
\end{tabular}

Datação

primeira metade do séc. VI d.C.

Elem. de datação

\section{Capitéis}

\section{Informações Complementares}

A igreja faz parte de um complexo, que compreende além dela um batistério, uma capela mortuária e um monastério. Tem um átrio com $26 \times 19 \mathrm{~m}$ de dimensões. Antes dessa configuração final, essa igreja passou por um estágio, na segunda metade do séc. IV, onde era monoabsidal.

\begin{tabular}{|l|c|c|}
$\begin{array}{c}\text { Bibliografia } \\
\text { autor }\end{array}$ & titulo & localização \\
\hline Stern & TNEAEHL & vol. IV/ pp. 1407-1409 \\
\hline
\end{tabular}

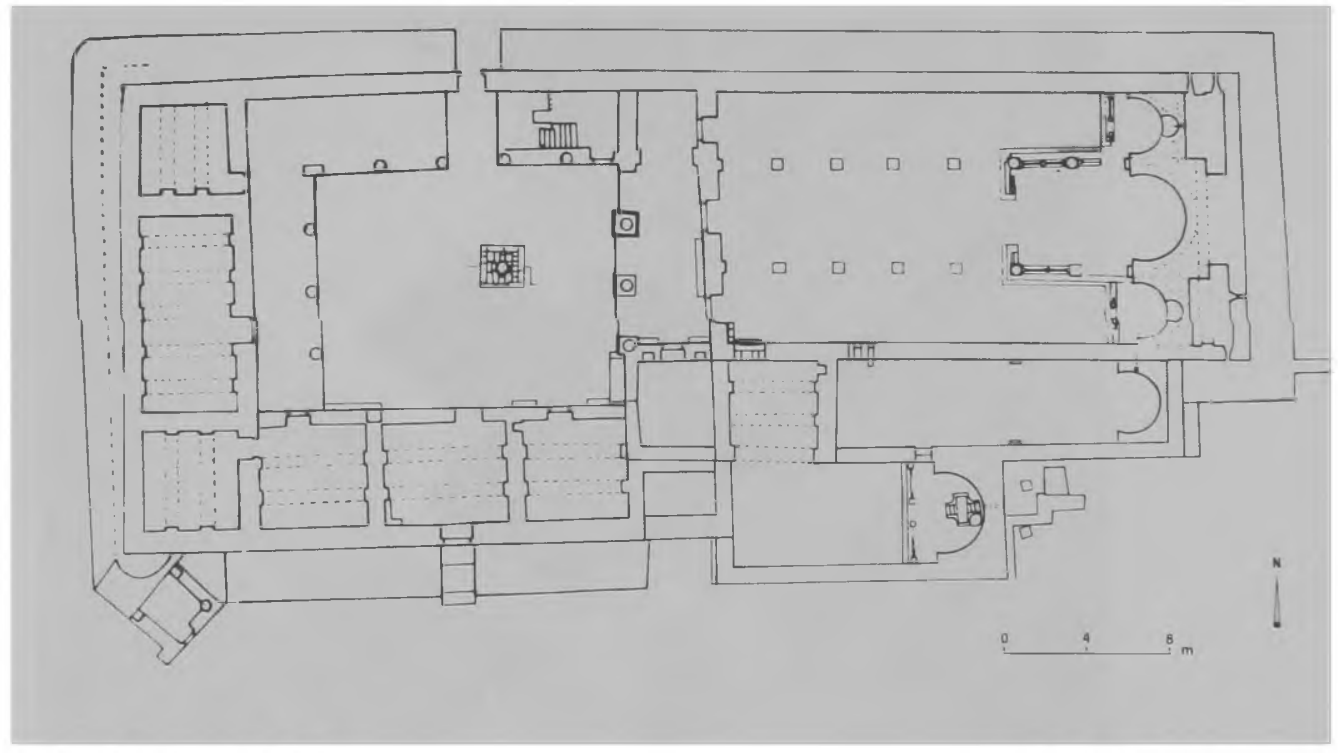

Planta da Igreja Norte

Sobata02_01.jpg 


Local Suhmata

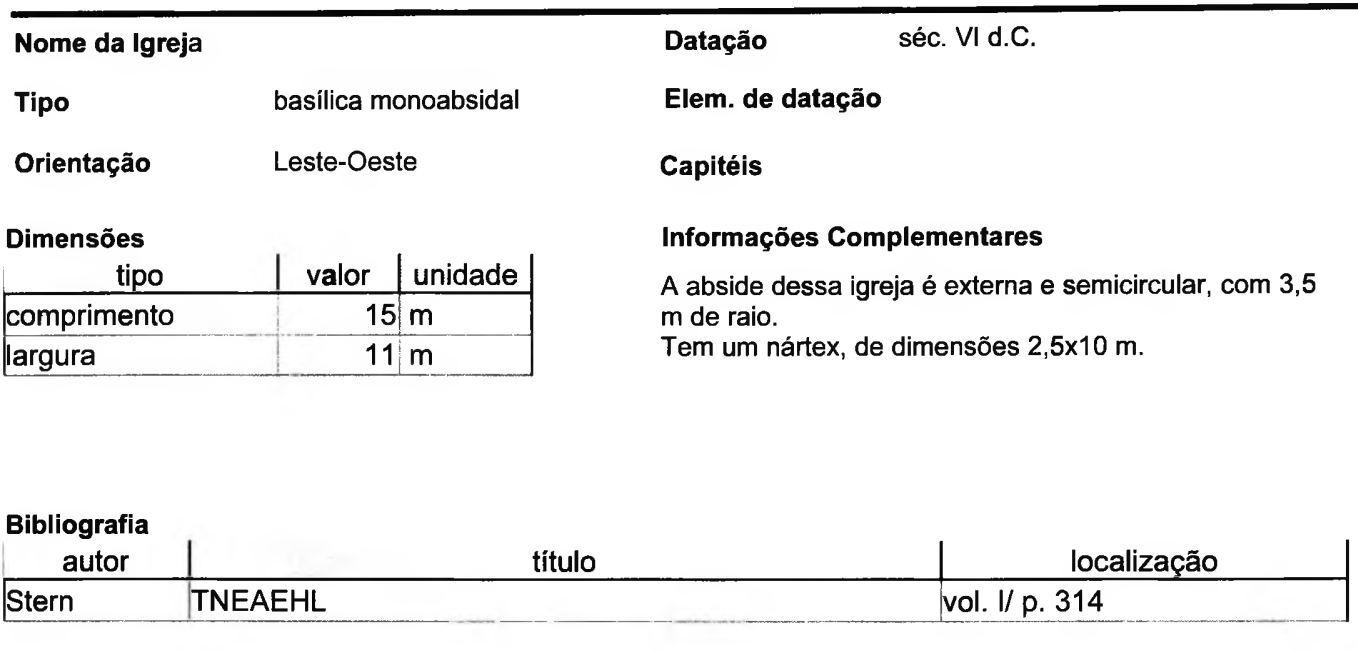
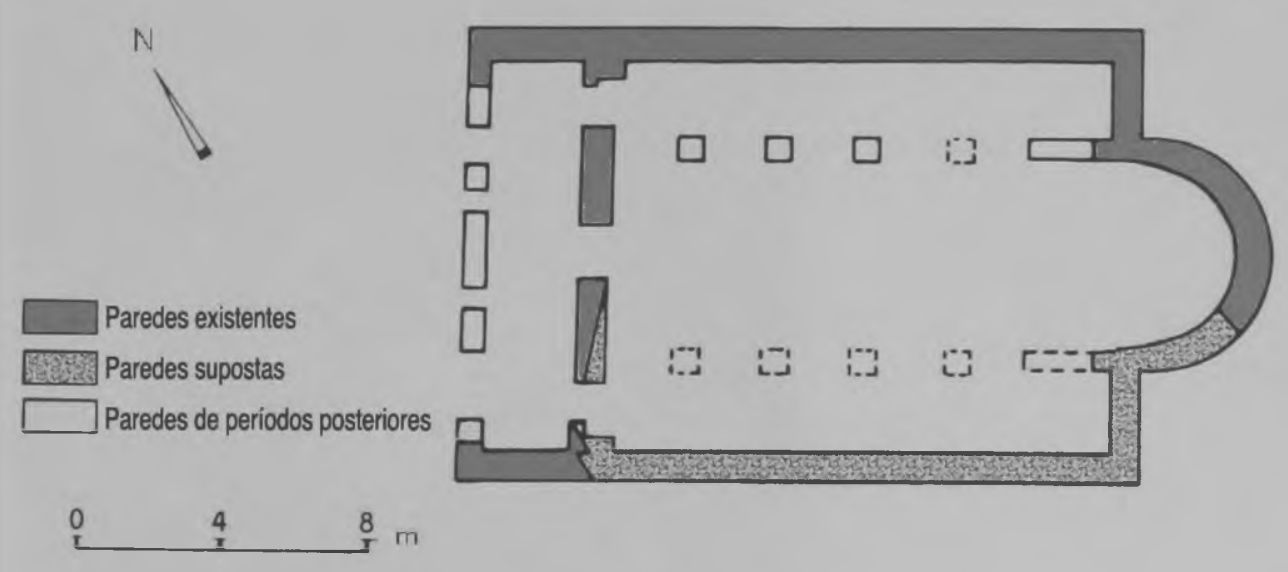


\section{Local Tel Aviv}

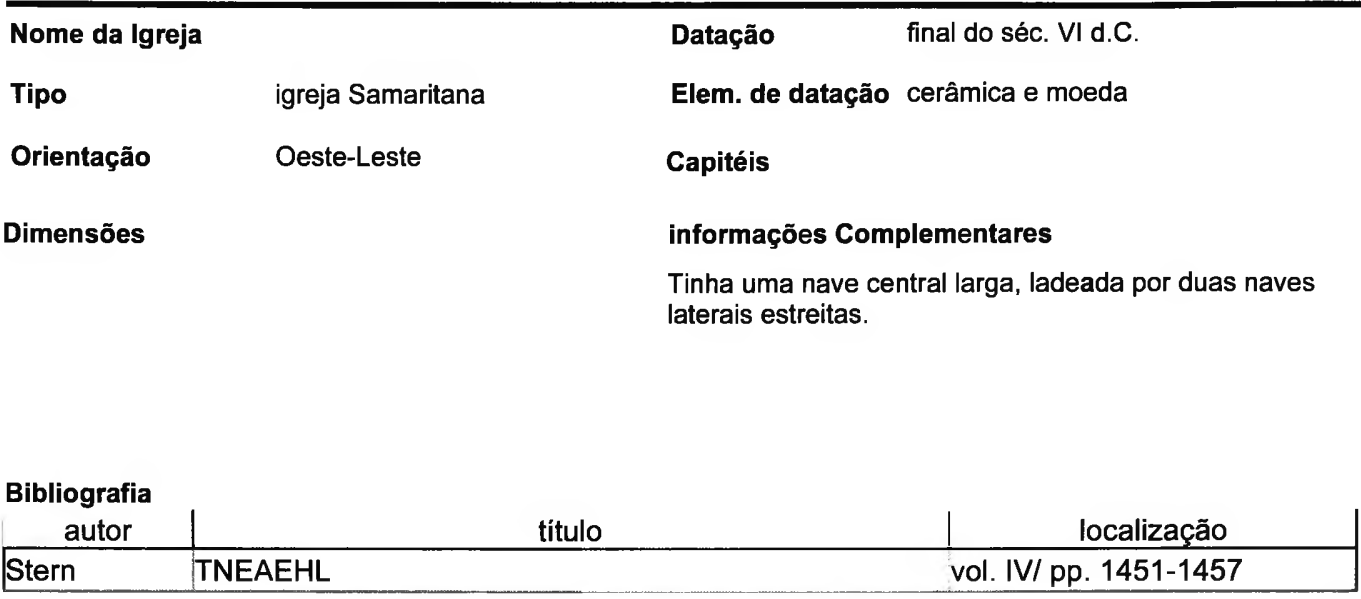

\section{Arquivo}

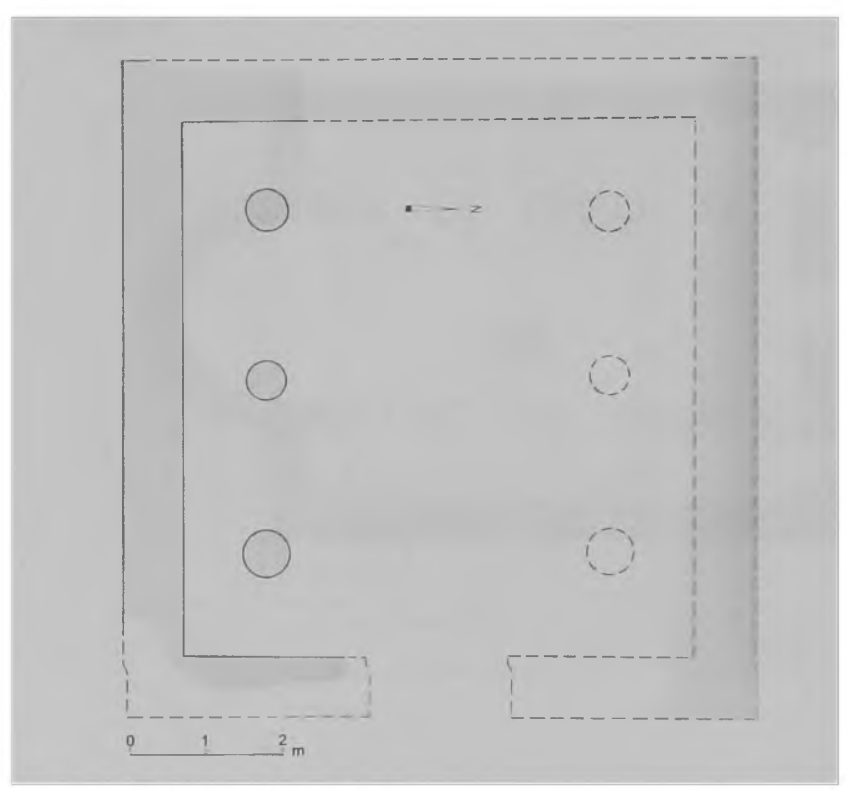

Planta da igreja Samaritana 
Local Umm Er-Rasas

Nome da Igreja Igreja dos Leōes

Tipo

basílica triabsida

Orientaçāo

Dimensões

\begin{tabular}{|l|c|c|}
$\begin{array}{c}\text { Bibliografia } \\
\text { autor }\end{array}$ & titulo & localização \\
\hline Stern & TNEAEHL & vol. IV/ pp. 1490-1493
\end{tabular}

Datação 587 d.C.

\section{Elem. de datação}

\section{Capitéis}

\section{Informações Complementares}

Junto à igreja existe uma torre, com altura de $14 \mathrm{~m}$.

\section{Arquivo}

Ficha XCIX

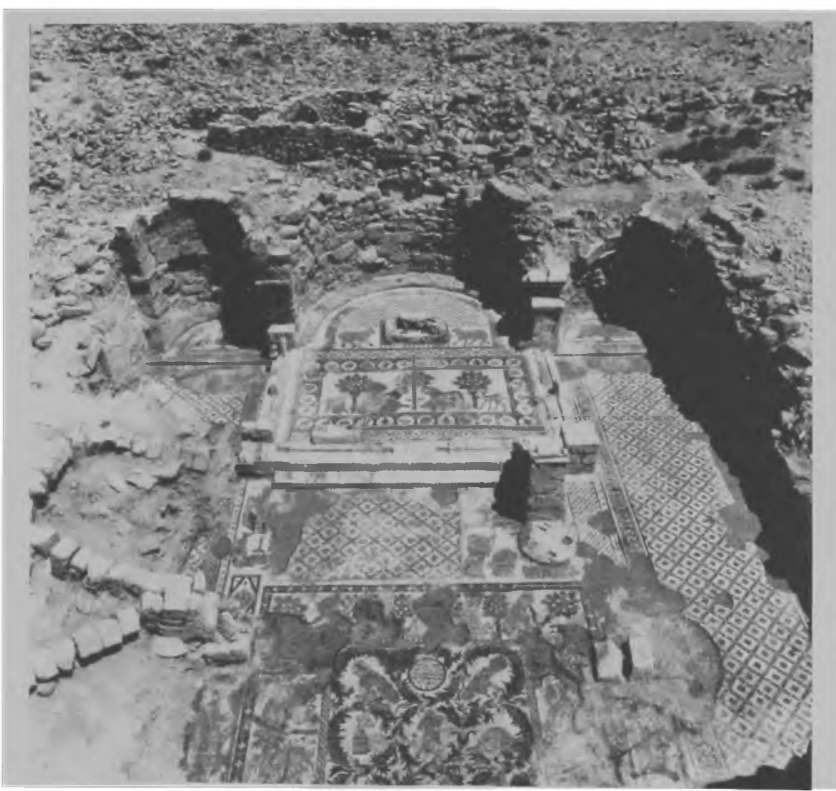

Vista geral da Igreja dos Leões 


\section{Local Umm Er-Rus}

Nome da Igreja Datação fim do séc. V/ início do séc. VI d.C.

Tipo basílica monoabsidal

Orientação

Dimensões

Bibliografia

\begin{tabular}{|c|c|}
\hline & TNEAEHL \\
\hline
\end{tabular}

\section{Elem. de datação}

\section{Capitéis}

Informações Complementares

A abside dessa igreja era externa. 
Local Yaduda, El

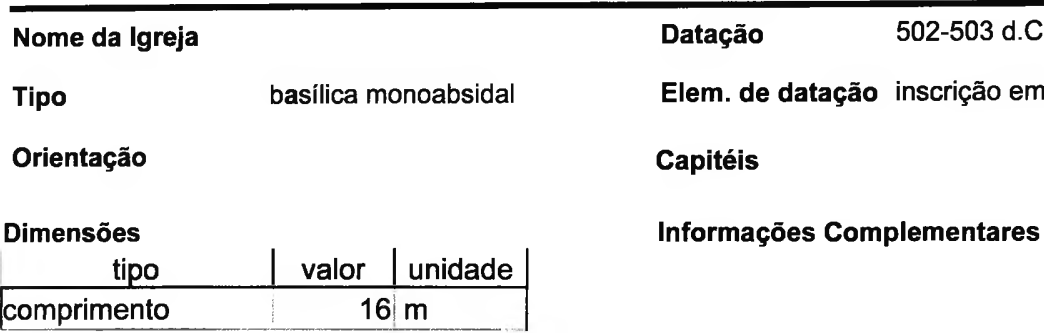

Bibliografia

\begin{tabular}{|l|l|l|}
\multicolumn{1}{c}{ autor } & título & localização \\
\hline Stern & TNEAEHL & vol. I/p. 314 \\
\hline
\end{tabular}




\section{Gráficos e tabelas}

\section{Tipos de igrejas}

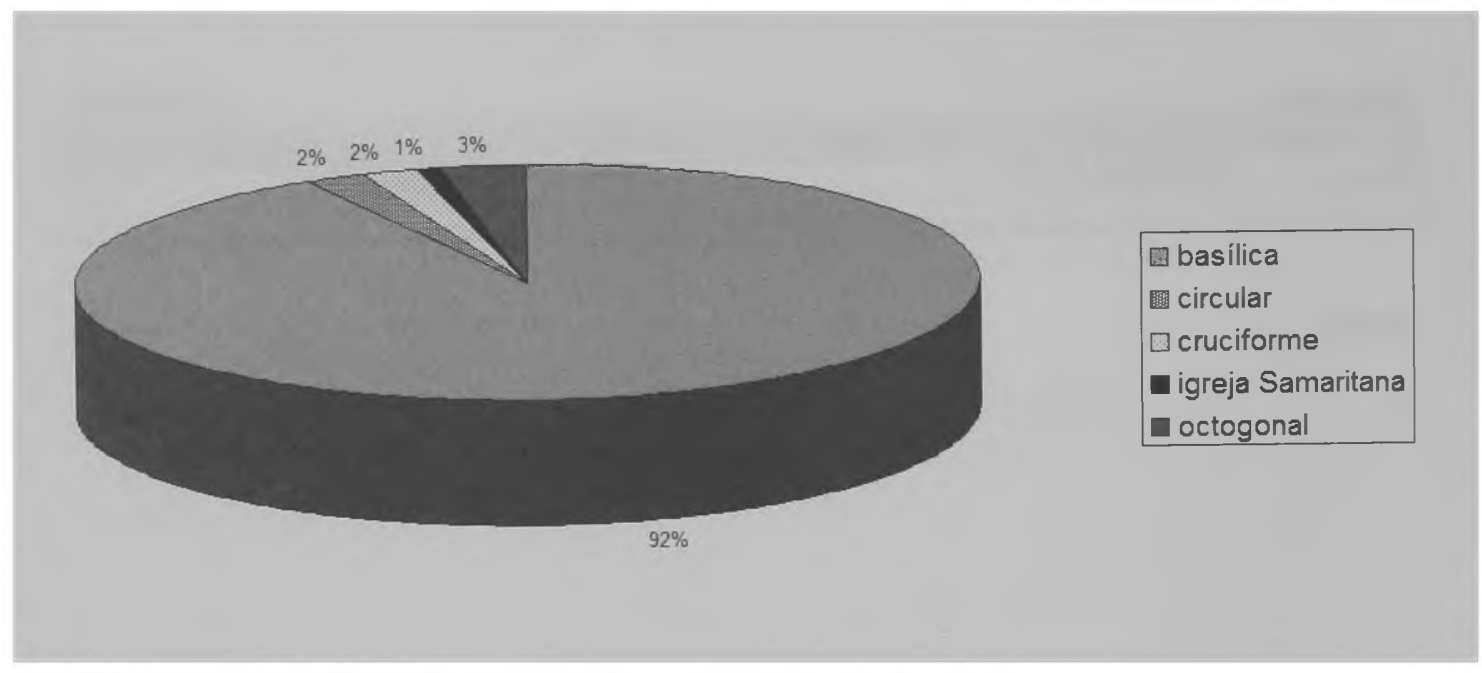

\begin{tabular}{|c|c|}
\hline Tipos & Quant. \\
\hline Basílica & 93 \\
\hline Circular & 2 \\
\hline Cruciforme & 2 \\
\hline Igreja Samaritana & 1 \\
\hline Octogonal & 3 \\
\hline Total geral & $\mathbf{1 0 1}$ \\
\hline
\end{tabular}




\section{Tipos de basílicas}

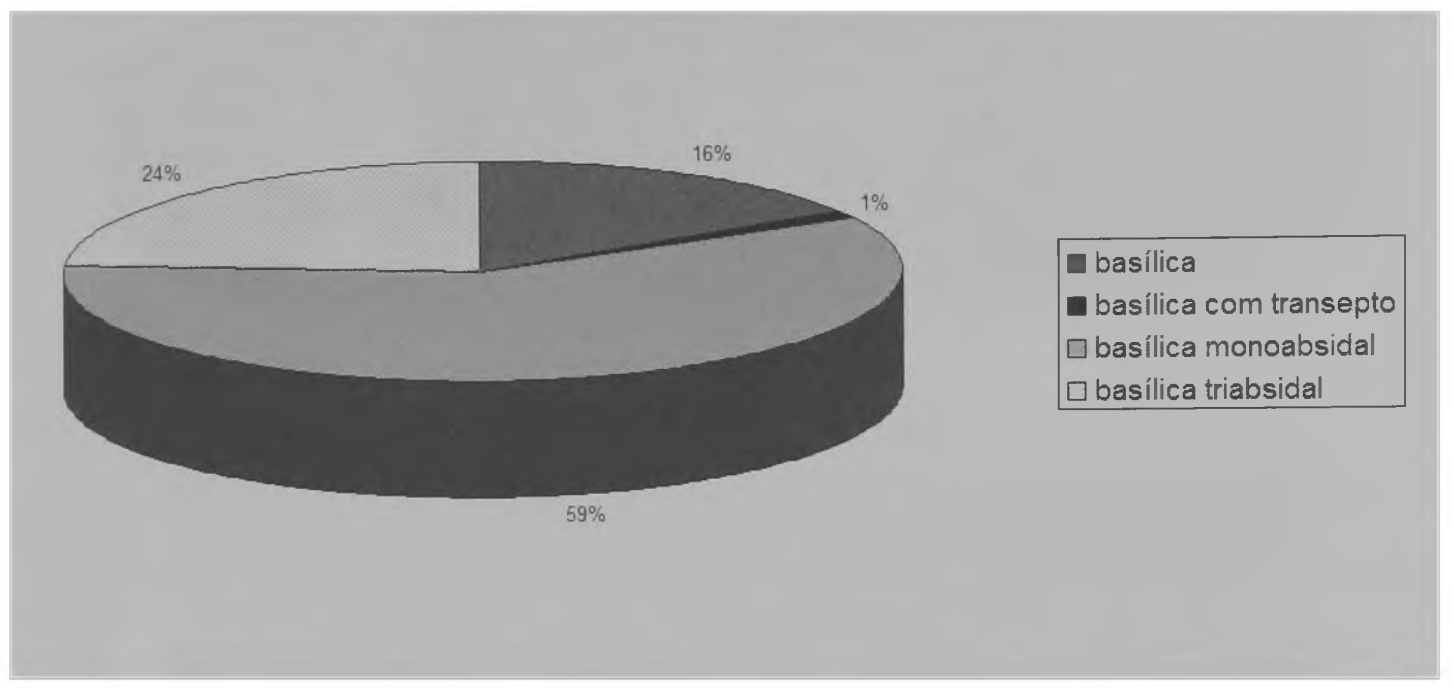

Tipos de Basílicas

Quant.

\begin{tabular}{|c|c|}
\hline Basílica & 15 \\
\hline Basílica com transepto & 1 \\
\hline Basílica monoabsidal & 55 \\
\hline Basílica triabsidal & 22 \\
\hline Total geral & 93 \\
\hline
\end{tabular}




\section{3. Época}

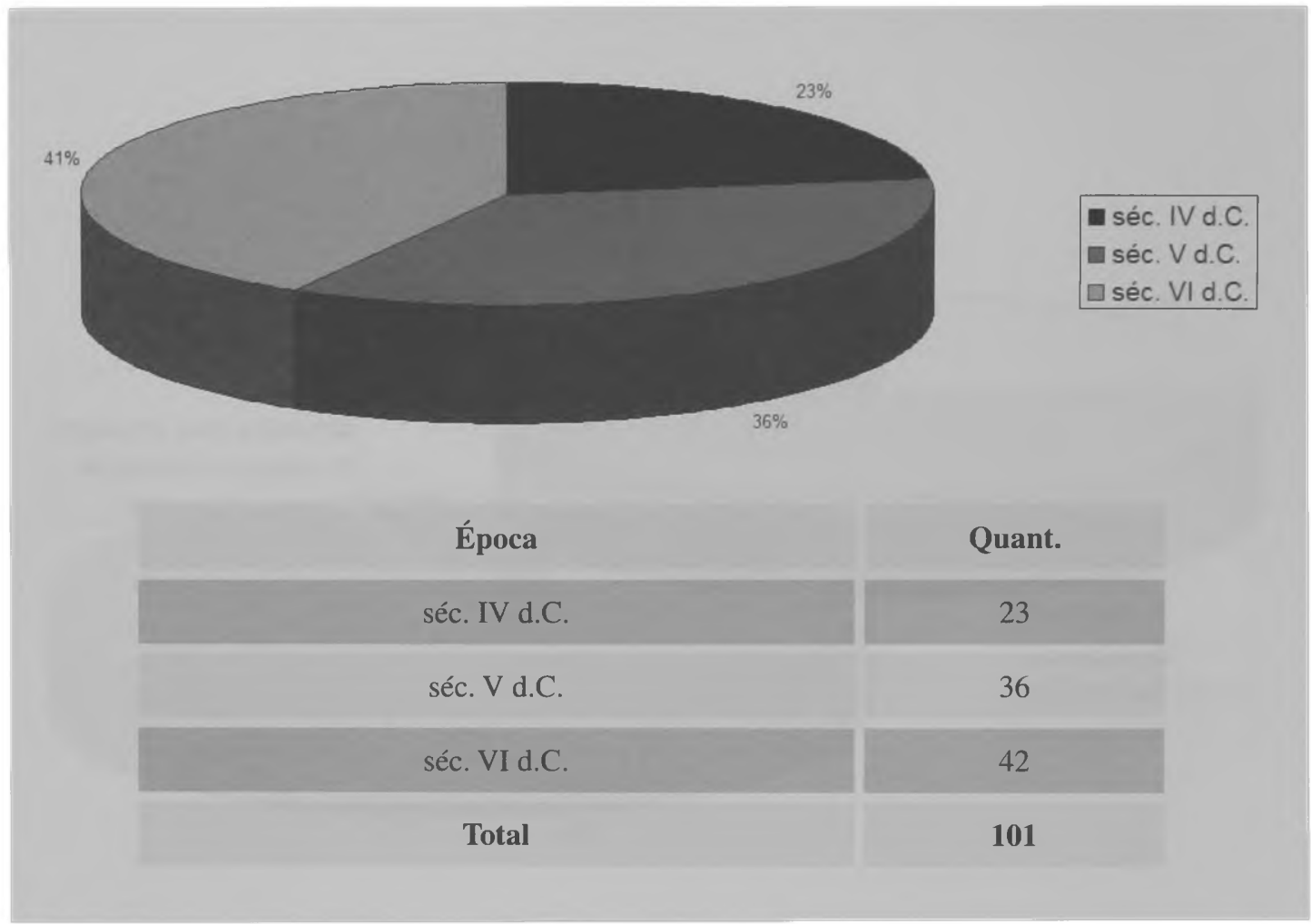

\section{Tipologia por séculos}

\begin{tabular}{|c|c|c|c|c|}
\hline Tipos & séc. IV d.C. & séc. V d.C. & séc. VI d.C. & Total \\
\hline basílica & & 6 & 9 & 15 \\
\hline basílica com transepto & & 1 & & 1 \\
\hline basílica monoabsidal & 15 & 20 & 20 & 55 \\
\hline basílica triabsidal & 6 & 5 & 11 & 22 \\
\hline circular & 1 & 1 & & 2 \\
\hline cruciforme & 1 & 1 & 1 & 1 \\
\hline igreja Samaritana & & & 1 & 3 \\
\hline octogonal & $\mathbf{2 3}$ & $\mathbf{3 6}$ & $\mathbf{4 2}$ & $\mathbf{1 0 1}$ \\
\hline Total & & & \\
\hline
\end{tabular}




\section{Orientação das igrejas}

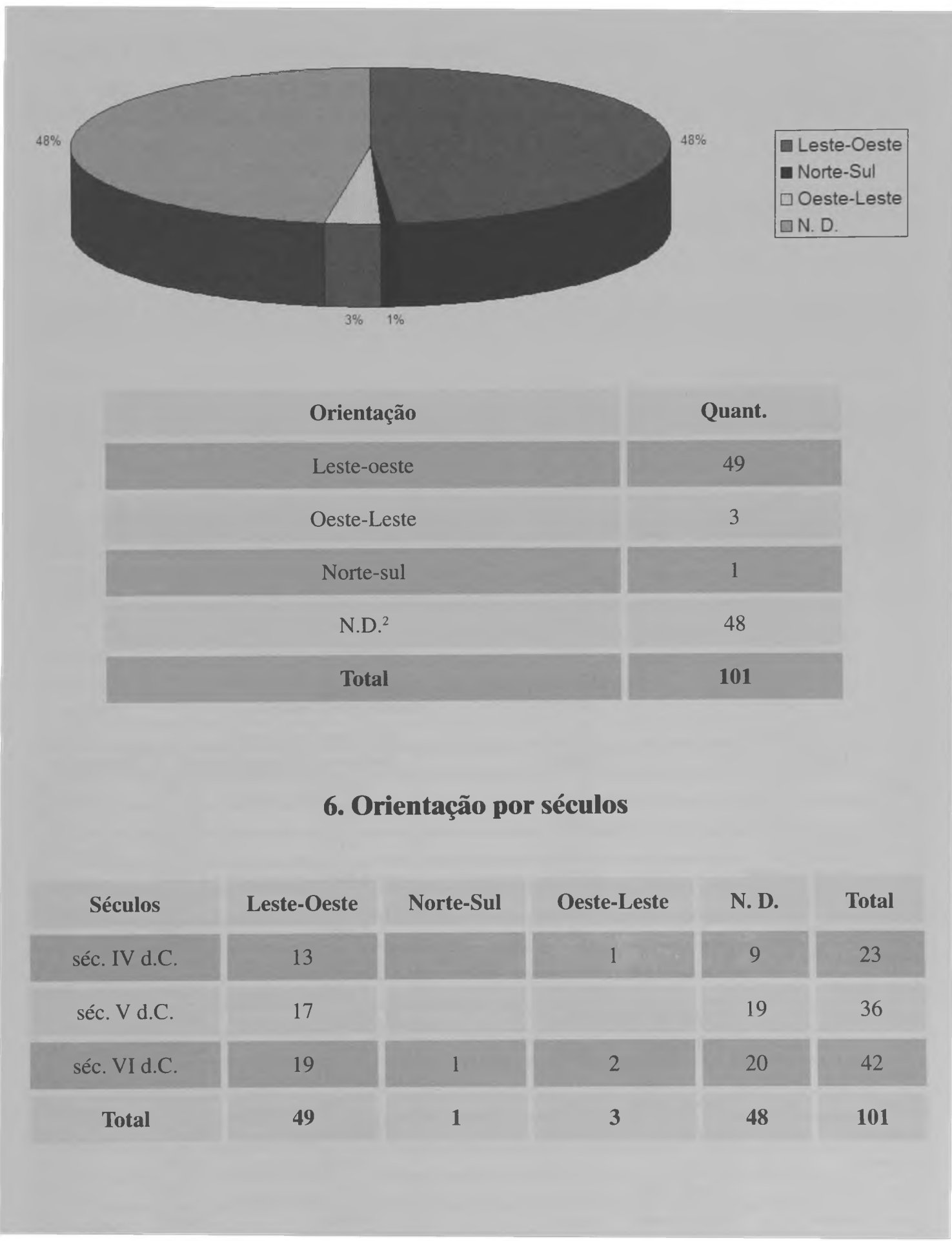

2 Usamos a notação N. D. nas tabelas para designar os dados que não foram disponibilizados pelas nossas fontes arqueológicas. 


\section{Orientação por tipo}

\begin{tabular}{|c|c|c|c|c|c|}
\hline Tipo & Leste-Oeste & Norte-Sul & Oeste-Leste & N. D. & Total \\
\hline basílica & 1 & 1 & & 13 & 15 \\
\hline basílica com transepto & 1 & & & & 1 \\
\hline basílica monoabsidal & 31 & & 2 & 22 & 55 \\
\hline basílica triabsidal & 14 & & 8 & 22 \\
\hline circular & 1 & & & 1 \\
\hline circular (rotunda) & & & 1 & 1 \\
\hline cruciforme & & & & 2 & 1 \\
\hline igreja Samaritana & & & & 2 & 3 \\
\hline octogonal & 1 & & & & \\
\hline Total & $\mathbf{4 9}$ & $\mathbf{1}$ & $\mathbf{3}$ & & \\
\hline
\end{tabular}

\section{Proporções das basílicas}

\begin{tabular}{|l|l|r|r|r|}
\hline \multicolumn{1}{|c|}{ Local } & Nome & Largura & \multicolumn{1}{c|}{ Comprimento } & Proporção \\
\hline Abila & & 18.00 & 32.00 & 0.56 \\
\hline 'Agur & & 10.00 & 13.00 & 0.77 \\
\hline 'Asida, Khirbet & & 9.00 & 12.00 & 0.75 \\
\hline Be'er Shema, Horvat & & 12.50 & 21.00 & 0.60 \\
\hline Beiyudat, Khirbet El- & & 16.00 & 24.00 & 0.67 \\
\hline Berakhot, Horvat & & 12.00 & 16.00 & 0.75 \\
\hline Beth Loya, Horvat & & 13.90 & 20.40 & 0.68 \\
\hline Beth Yerah & & 11.50 & 12.50 & 0.92 \\
\hline Bethlehem & Igreja da Natividade & 26.50 & 26.50 & 1.00 \\
\hline Dor & Dora-Dor & 14.00 & 18.50 & 0.76 \\
\hline 'Ein Haniya & & 10.00 & 15.00 & 0.67 \\
\hline Elusa & Igreja Leste & 17.70 & 39.45 & 0.45 \\
\hline Emmaus & Igreja 1 & 24.40 & 46.40 & 0.53 \\
\hline Emmaus & Igreja 2 & 10.00 & 18.00 & 0.56 \\
\hline 'Erav, Horvat & Igreja Oeste & 14.10 & 17.90 & 0.79 \\
\hline 'Erav, Horvat & Igreja Leste & 16.00 & 20.00 & 0.80 \\
\hline 'Evron & & 10.60 & 14.50 & 0.73 \\
\hline
\end{tabular}




\begin{tabular}{|c|c|c|c|c|}
\hline Local & Nome & Largura & Comprimento & Proporção \\
\hline Gerasa & \begin{tabular}{|l|} 
Igrejas de São João Batista, São \\
Jorge, São Cosme e Damião
\end{tabular} & 14.00 & 29.50 & 0.47 \\
\hline Gerizim, Mount & Igreja de Maria, mãe de Jesus & 30.00 & 37.40 & 0.80 \\
\hline Giv'it Horvat & & 10.50 & 14.70 & 0.71 \\
\hline Hanita & & 14.00 & 17.00 & 0.82 \\
\hline Haspin & Igreja Oeste (Igreja de Georgius) & 14.20 & 20.50 & 0.69 \\
\hline Haspin & Igreja Leste (Igreja de Thomas) & 8.70 & 12.75 & 0.68 \\
\hline Hazor-Ashdod & & 10.50 & 12.50 & 0.84 \\
\hline Heptapegon & & 19.00 & 25.00 & 0.76 \\
\hline Herodium & Igreja Norte & 8.80 & 10.60 & 0.83 \\
\hline Herodium & Igreja Central & 10.50 & 11.50 & 0.91 \\
\hline Herodium & Igreja Leste & 10.00 & 17.00 & 0.59 \\
\hline Hesheq, Horvat & & 16.00 & 21.00 & 0.76 \\
\hline Hippos & Catedral & 20.00 & 40.00 & 0.50 \\
\hline Hubeila, Khirbet El- & & 12.50 & 16.00 & 0.78 \\
\hline Jericho & Igreja da Virgem Santa (?) & 20.00 & 36.00 & 0.56 \\
\hline Jerusalém & Igreja do Santo Sepulcro & 40.00 & 49.00 & 0.82 \\
\hline Jerusalém & Igreja de Siloam & 16.00 & 28.00 & 0.57 \\
\hline Jerusalém & Igreja "Nea" & 57.00 & 115.00 & 0.50 \\
\hline Jerusalém & Igreja do Santo Zion & 37.00 & 52.00 & 0.71 \\
\hline Jerusalém & Igreja de Santa Maria & 20.00 & 28.00 & 0.71 \\
\hline Jerusalém & Igreja de Santo Estevão & 20.00 & 33.00 & 0.61 \\
\hline Jerusalém & Igreja Eleona & 20.00 & 30.00 & 0.67 \\
\hline Jerusalém & Igreja do Gethsemani & 16.50 & 22.50 & 0.73 \\
\hline Jerusalém & Igreja do Giv'at Ram & 14.00 & 17.50 & 0.80 \\
\hline Jerusalém & Igreja em Ketef Hinnom & 25.00 & 45.00 & 0.56 \\
\hline Kissufim & Igreja de Santo Elias & 13.00 & 16.00 & 0.81 \\
\hline Kurnub & Igreja Leste & 15.00 & 27.50 & 0.55 \\
\hline Kurnub & Igreja Oeste & 10.00 & 17.50 & 0.57 \\
\hline Kursi & & 25.00 & 45.00 & 0.56 \\
\hline Mareshah & & 9.90 & 9.60 & 1.03 \\
\hline Medeba & Igreja dos Apóstolos & 15.30 & 23.50 & 0.65 \\
\hline Medeba & Igreja do mapa de Medeba & 15.00 & 25.00 & 0.60 \\
\hline Mishmar Ha-'Emeq & & 4.50 & 10.00 & 0.45 \\
\hline Mount Nebo & Memorial de Moisés em Siyagha & 14.50 & 36.00 & 0.40 \\
\hline Mount Nebo & Igreja Superior & 12.30 & 15.00 & 0.82 \\
\hline Mount Nebo & Igreja do Diácono Tomas & 10.50 & 14.00 & 0.75 \\
\hline Nahariya & & 16.00 & 32.00 & 0.50 \\
\hline Nazareth & Igreja da Anunciação & 6.70 & 9.00 & 0.74 \\
\hline Nessana & Igreja Norte & 10.70 & 19.00 & 0.56 \\
\hline Nessana & Igreja Sul & 14.10 & 20.80 & 0.68 \\
\hline Oboda & Igreja Norte & 14.50 & 22.50 & 0.64 \\
\hline Oboda & Igreja Sul & 14.00 & 25.00 & 0.56 \\
\hline Ostrakine & & 20.00 & 33.00 & 0.61 \\
\hline Pella & Igreja Leste & 20.00 & 32.00 & 0.63 \\
\hline Rabbath Ammon & & 12.30 & 20.30 & 0.61 \\
\hline
\end{tabular}




\begin{tabular}{|l|l|r|r|r|}
\hline \multicolumn{1}{|c|}{ Local } & Nome & Largura & \multicolumn{1}{c|}{ Comprimento } & \multicolumn{1}{c|}{ Proporção } \\
\hline Rehovot-in-the-Negev & Igreja Norte & 14.00 & 25.00 & 0.56 \\
\hline Rehovot-in-the-Negev & Igreja Central & 16.30 & 20.00 & 0.82 \\
\hline Roglit & & 10.70 & 14.00 & 0.76 \\
\hline Shavei Zion & & 16.00 & 27.00 & 0.59 \\
\hline Shepherd's Field & Igreja dos Pastores & 13.30 & 20.50 & 0.65 \\
\hline Shiloh & Igreja dos Peregrinos & 11.70 & 25.00 & 0.47 \\
\hline Shiloh & Basílica & 15.10 & 18.00 & 0.84 \\
\hline Sinai & Igreja de Santa Catarina & 12.00 & 25.00 & 0.48 \\
\hline Sobata & Igreja Sul & 18.20 & 17.60 & 1.03 \\
\hline Sobata & Igreja Norte & 13.00 & 20.00 & 0.65 \\
\hline Suhmata & & 11.00 & 15.00 & 0.73 \\
\hline
\end{tabular}

\section{Proporções das basílicas}
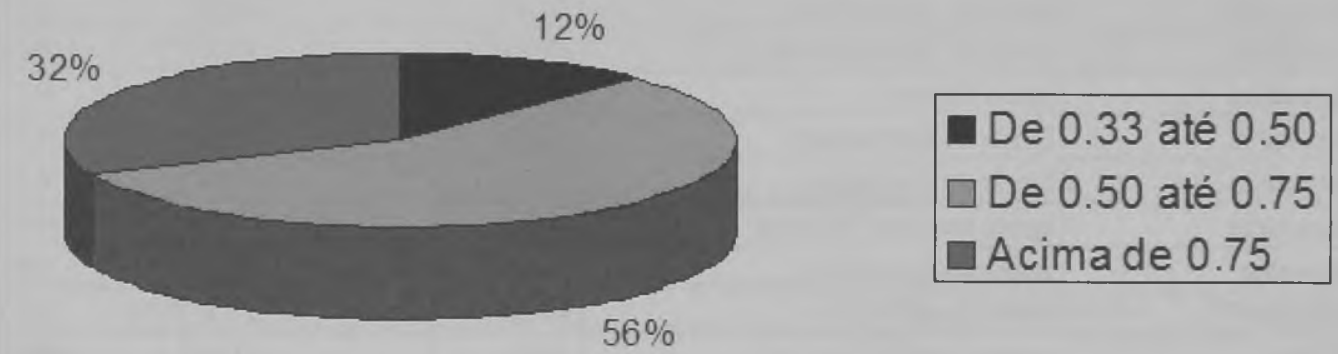

Proporção

\section{Quantidade}

De 0.33 até 0.50

9

De 0.50 até 0.75 


\section{Ocorrência de capitéis}

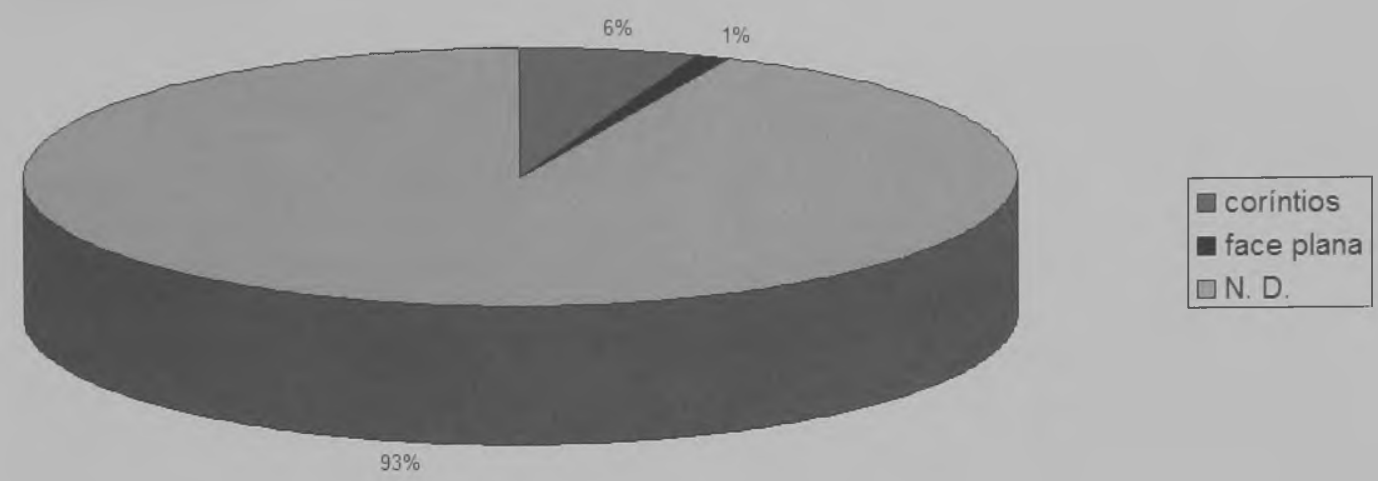

\begin{tabular}{|c|c|}
\hline Tipo & Quant. \\
\hline Coríntio & 6 \\
\hline Face Plana & 1 \\
\hline N.D. & 94 \\
\hline Total & $\mathbf{1 0 1}$ \\
\hline
\end{tabular}





\section{4 - Considerações sobre a permanência de elementos clássicos nas igrejas paleocristãs}

$V$ Tários autores que lidam com a questão do espaço construído, como Perring (1991), Rapoport $(1977$; 1982) e Duncan (1990), entendem que o espaço arquitetônico é organizado para obter respostas específicas, daí temos que as mudanças em sua ordenação acompanham as transformações sociais. Eles procuram nos mostrar que as mudanças formais, expressas no desenho do ambiente, fazem parte de um processo de informações codificadas, e a tarefa de seus usuários é decodificá-las; isso só ocorrerá da maneira esperada se o indivíduo que usa o espaço conhecer o código que é utilizado. Por outro lado, existem alguns elementos que permanecem no espaço, estabelecendo um ponto de ligação entre as formas passadas e as formas presentes nesses momentos de mudança. Tendo essas observações em mente e interpretando os elementos arquitetônicos como uma forma de expressão de uma comunicação nãoverbal, procuraremos entender a importância da permanência ou mudança das formas construídas nas igrejas paleocristãs para a atividade que se realiza no seu ambiente, para a compreensão da sociedade que a criou assim como todo o universo que configura o momento de mudança onde esses edifícios se inserem.

Para a elaboração desse trabalho definimos um recorte geográfico e temporal bem delimitado $^{3}$. A proposta foi estudar as primeiras igrejas cristãs construídas na região da Palestina entre os séculos IV e VI d.C. Uma vez identificadas as igrejas que fariam parte do nosso catálogo, procuramos posicioná-las no mapa da Palestina. A partir dessa informação, percebemos que uma grande parte das localidades onde foi atestada a existência de igrejas no período estudado concentra-se na região central do território, próximas às cidades de $\mathrm{Be}$ lém e Jerusalém. Como foi exposto, essas duas

3 Os critérios adotados para o estabelecimento desses recortes foram apresentados na introdução desse trabalho, pp. 5-6. cidades eram de extrema importância para o cristianismo porque foram os locais onde, respectivamente, Jesus Cristo nasceu e morreu e por causa desses eventos tornaram-se locais de peregrinação cristã. Tanto em Belém quanto em Jerusalém, Constantino mandou construir igrejas grandiosas. Por serem locais de peregrinação, acabaram por se tornar pontos importantes de difusão e propagação da religião cristã e talvez essa característica justifique a existência de igrejas em tantos lugares próximos: pela convivência, membros das comunidades vizinhas poderiam adotar a religião e construir mais edifícios para culto. A ocorrência de igrejas cristãs não se restringe apenas a essa região, mas espalha-se por todo o território: ao norte, na região do mar da Galiléia, a Leste, ultrapassando o rio Jordão, e também ao sul, em algumas localidades da região do Neguev. É interessante também notar a escassa ocorrência de igrejas no litoral da Palestina, que tem como limite o mar Mediterrâneo. Das 101 igrejas estudadas, apenas 4 se estabeleceram em cidades litorâneas. Não conseguimos encontrar em nossas leituras nenhum fator que justificasse a rara ocorrência de igrejas no litoral.

Com os dados obtidos quando da elaboração do catálogo, uma primeira informação relevante para nosso estudo vem dos tipos de igreja construídos nessa fase inicial de desenvolvimento do Cristianismo. Como pode ser observado na tabela 1 , da p. 150, que diz respeito à sua tipologia, a basílica é o tipo predominante, adotado para mais de $90 \%$ das igrejas erigidas no período estudado. Segundo Stern, a basílica foi, aparentemente, o tipo mais comum de edifício construído no período bizantino. Pelo levantamento das igrejas apresentadas por Stern em sua enciclopédia de escavações na região da Palestina, a TNEAEHL, e por Tsafrir em ACR, sua obra sobre igrejas antigas, (Stern 1993; Tsafrir 1993), podemos 
comprovar essa hipótese e afirmar com segurança que a maioria das igrejas paleocristãs (sécs. IV a VI d.C.) têm a forma de basílica, como mostra a tabela 1(p.150). Com os dados apresentados decidimos focalizar nossas análises no modelo de basílica e desprezar os outros em razão de sua rara ocorrência nas igrejas cristãs do período estudado.

Ao visualizar a basílica como o modelo adotado preferencialmente na construção dos primeiros edifícios de culto cristão, nos dedicamos ao estudo das formas arquitetônicas dos períodos anteriores, a fim de identificar alguma estrutura que remetesse à basílica cristã. $O$ que percebemos a partir dessa digressão foi que a forma de basílica, muito utilizada em igrejas católicas de época bizantina, mostra sinais muito claros de influência das basílicas seculares romanas. Essas basílicas como já apresentamos no capítulo 2, eram edifícios ligados ao fórum, usados para reuniões sociais e realização de negócios e que abrigavam dependências administrativas do governo, onde também se realizavam julgamentos. É importante ressaltar que em época romana as basílicas não tinham a função específica de culto religioso como as igrejas, apesar de autores como Carter (1995:41) relatarem que em algumas basílicas romanas era realizada a veneração da família imperial, que não deixa de ser um tipo de culto.

Wheeler (1995:112-115) nos informa que na basílica de Pompéia o acesso se dá através de um pórtico em um dos seus lados menores, tendo o tribunal no lado oposto (fig. 9). Além disso, a posição desse edifício em relação ao fórum é peculiar, porque ele se situa em um canto do fórum, ocupando apenas parte de um de seus lados maiores (fig. 8). Essa situação difere daquela apresentada pelas basílicas Aemilia e Julia, nas quais o acesso se dava por um de seus lados maiores e o edifício encerrava um dos lados do fórum. Basílicas como essas são classificadas por Wheeler como do tipo "vitruviano" Estudos atestam que esses dois tipos, o "vitruviano" e o de Pompéia tiveram uma difusão parecida durante o final da República e início do Império Romano. Carter (1995:42) classifica esses dois tipos de basílica de uma outra forma: o tipo "longo" onde a entrada se faz por um dos lados menores e o tipo "amplo", que tem sua entrada num dos lados maiores. Para esse estudioso a distinção entre esses dois tipos não é significativa. Segundo Wheeler, o tipo de basílica pompeiana, com a entrada por um dos lados menores, influenciou o desenho das igrejas cristãs.

De fato, ao observarmos o traçado nas plantas dos dois tipos de basílicas, a civil romana e a cristã, veremos muitas semelhanças, não apenas com o tipo de basílica de Pompéia, que Wheeler afirma ser o tipo antecessor ao desenho das igrejas cristãs, mas também com os edifícios do tipo "vitruviano" ou "amplo" Nossas análises não seguem a sugestão de Wheeler, restringindo-se ao estudo das basílicas do tipo pompeianas como tipologia de origem das igrejas cristãs. Concordamos com Carter quando ele afirma que a distinção entre esses dois tipos de basílica não é significativa, e por isso buscamos ver no universo de basílicas romanas, com todos seus diferentes tipos, formas que, uma vez modificadas e adaptadas às novas necessidades de uso do espaço, se transformaram nas basílicas cristãs.

Se recuarmos ainda mais um pouco no tempo, podemos encontrar nos templos gregos algumas semelhanças com a forma da basílica cristã. O primeiro ponto de contato é o seu uso. O templo grego, assim como a igreja, é um edifício cuja finalidade específica é o culto religioso. Nos dois tipos de edifícios - a igreja e o templo - encontramos exemplos de estruturas monumentais, que marcam o seu espaço na paisagem e são marcos de referência, conhecidos não apenas no âmbito da cidade onde se localizam, mas por todo o universo da qual fazem parte, tais como a Igreja do Santo Sepulcro ou o Templo de Apolo em Delfos. No Ocidente encontramos alguns exemplos de templos gregos que serviram como base para a construção de basílicas cristãs. É interessante ressaltar que esses templos não foram destruídos para dar lugar às igrejas, mas o seu espaço foi adaptado conforme as necessidades da religião cristã. Este é o caso, por exemplo, do Athenaion de Siracusa, que no século VII d.C. teve sua estrutura aproveitada para abrigar uma igreja cristã. Para essa construção foi 


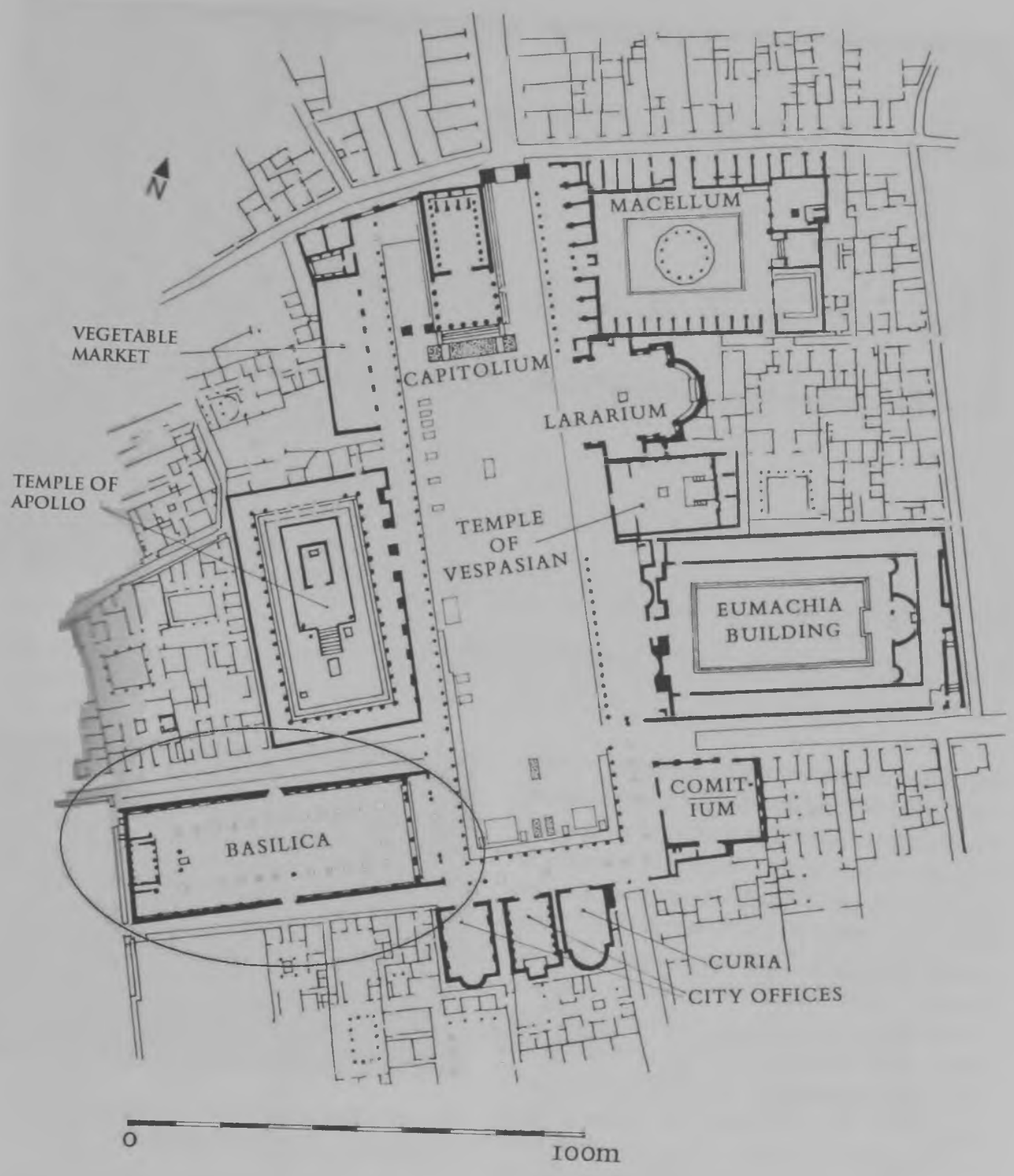

Fig. 8 - Planta do Fórum de Pompéia.

Fonte: WARD-PERKINS, J. B. Roman Imperial Architecture, p. 159. 


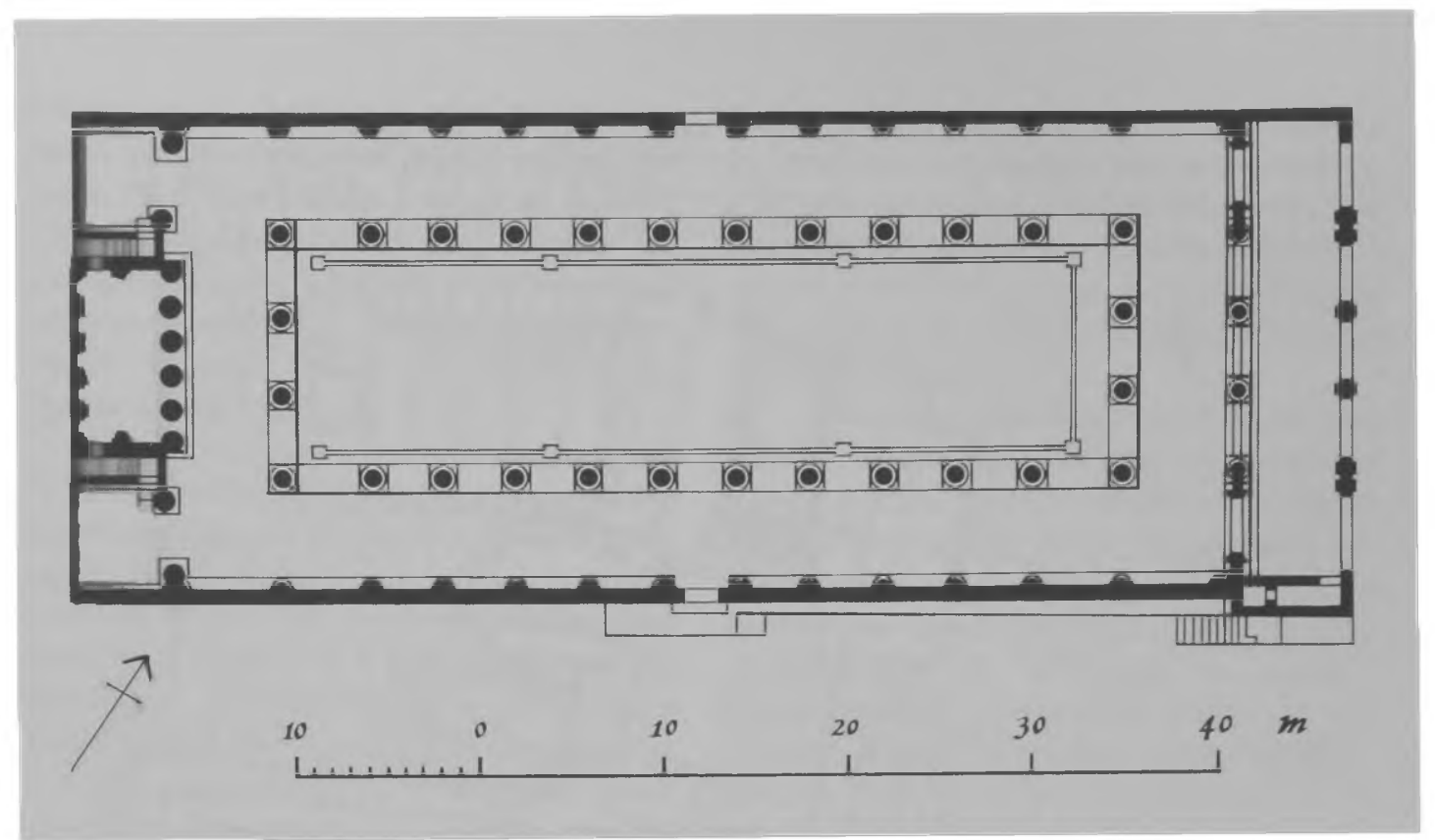

Fig. 9 - Planta da basílica de Pompéia, construída antes de 78 a.C.

Fonte: WHEELER, M. El Arte y la Arquitectura de Roma, p. 113.

utilizado um procedimento simples: "o edifício central foi transformado em nave central, e nas suas paredes laterais foram feitas aberturas em forma de arco, enquanto as naves laterais foram posicionadas no espaço ocupado entre essas paredes e a colunada, cujo intercolúnio foi fechado. Para unificar o espaço interno, naturalmente foi necessário demolir as divisões entre a cela, o pronaos e o opistódomo. Além disso, sua orientação foi modificada, pela necessidade de voltar para a direção Leste o coro da igreja, que ocupa o lugar da fachada do templo." (Coarelli 1988:233) Depois de ter sido consagrado como igreja no século VII d.C., esse templo passou por uma fase onde foi transformado em mesquita e posteriormente, em 1093, foi reconsagrado, e voltou a abrigar o culto cristão. A sua configuração atual (figs. 10 e 11) data de 1925, quando grande parte da ornamentação barroca foi eliminada, evidenciando a estrutura grega (Coarelli 1988:233-234). Atualmente esse edifício é a catedral de Siracusa.

No templo da Concórdia, em Agrigento, encontramos mais um exemplo de reaproveitamento do espaço do templo grego para sua

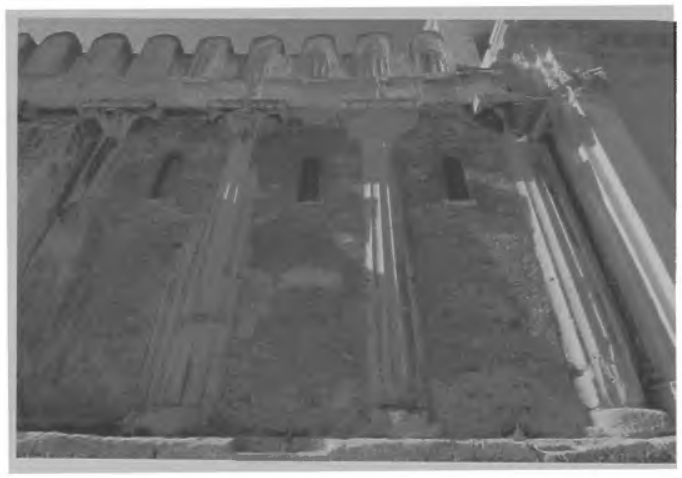

Fig. 10 - Fachada lateral do Athenaion, atualmente a Catedral de Siracusa

Foto: Wagner Souza e Silva Acervo Labeca

utilização como igreja. Nesse caso, a transformação em igreja cristã comportou uma inversão da orientação antiga; para tanto, a parede do fundo da cela, que a dividia com o opistódomo, foi demolida, os intercolúnios foram fechados e foram feitas 12 aberturas em arco nas 


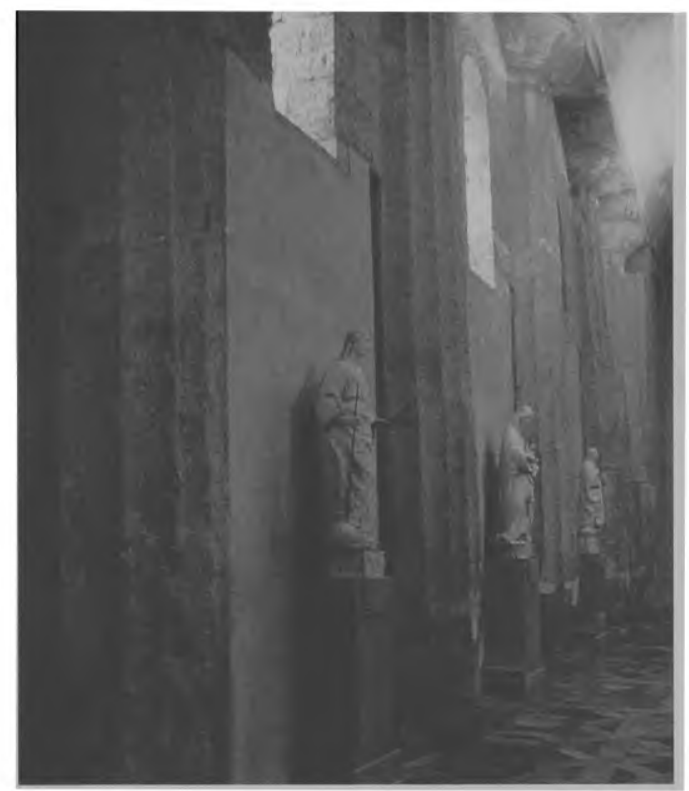

Fig. 11 - Catedral de Siracusa - vista do interior

Fonte: CERCHIAI, L., JANELLI, L. e LONGO, F. The Greek Cities of Magna Graecia and Sicily, p. 208. paredes dos dois lados maiores da cela, onde se construiu a nave canônica: as duas (naves) laterais na peristasis e a central no espaço que coincide com a largura da cela; com o altar de época clássica tendo sido destruído e no ângulo a Leste assentada a sacristia, o edifício se tornou um organismo com a perfeita forma de basílica. A igreja tinha um nártex, que podia ser acessado por uma escada e ocupava o espaço onde, no templo original, estava a transição entre o pronaos e a cela. A partir dele se alcançava as três naves da nova basílica, cujo comprimento era delimitado entre a colunada do pronaos e a da iconastasis. No espaço ocupado pelo iconostasis, um pequeno pseudo-transepto reunia o prothesis, o bema e o diaconicon, possivelmente de forma absidal e talvez com janelas (figs. 12, 13 e 14) (Coarelli 1988:138-139; Griffo 2005:83-84). Griffo (2005:77) destaca que o bom estado de conservação do templo grego, que ainda se mantém se deve em parte ao fato desse templo ter sido transformado em igreja cristã no século VI d.C.

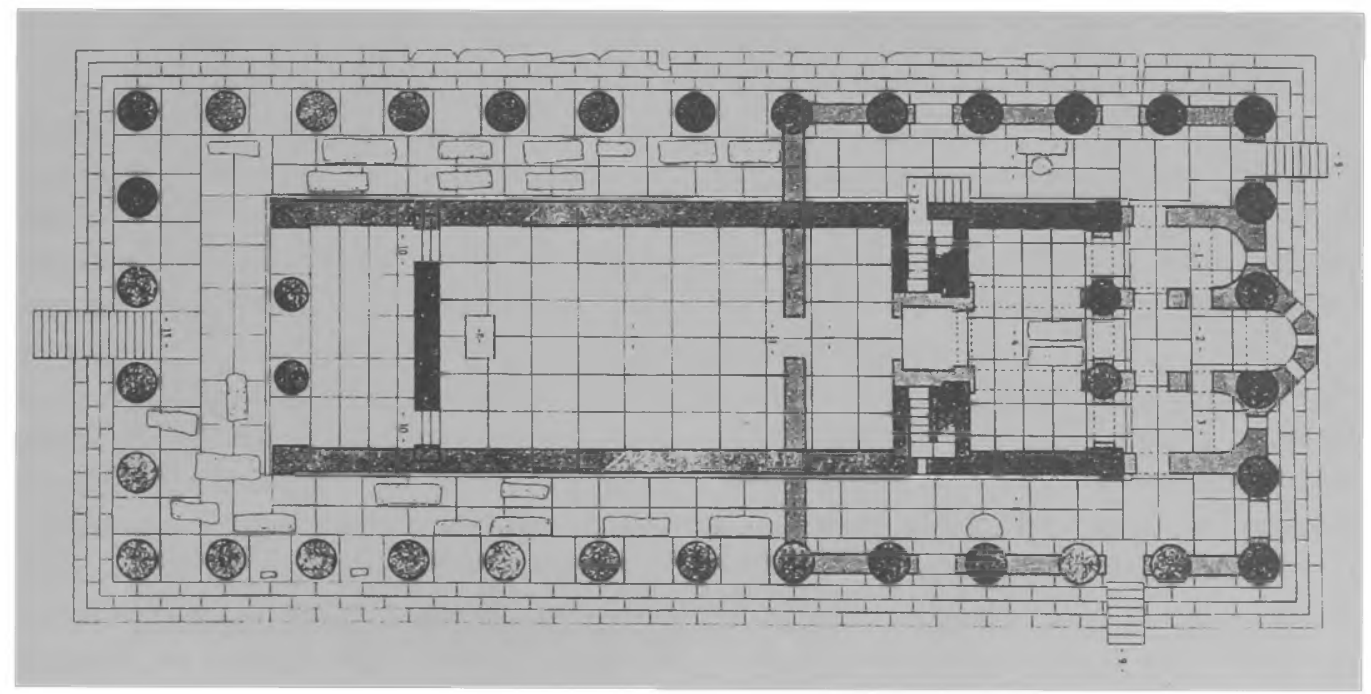

Fig. 12 - Templo da Concórdia: ajustes para basílica cristã, segundo a reconstituição de Trizzino.

Fonte: GRIFFO, P. Akragas - Agrigento: la storia, la topografia, I monumenti, gli scavi, p. 80. 


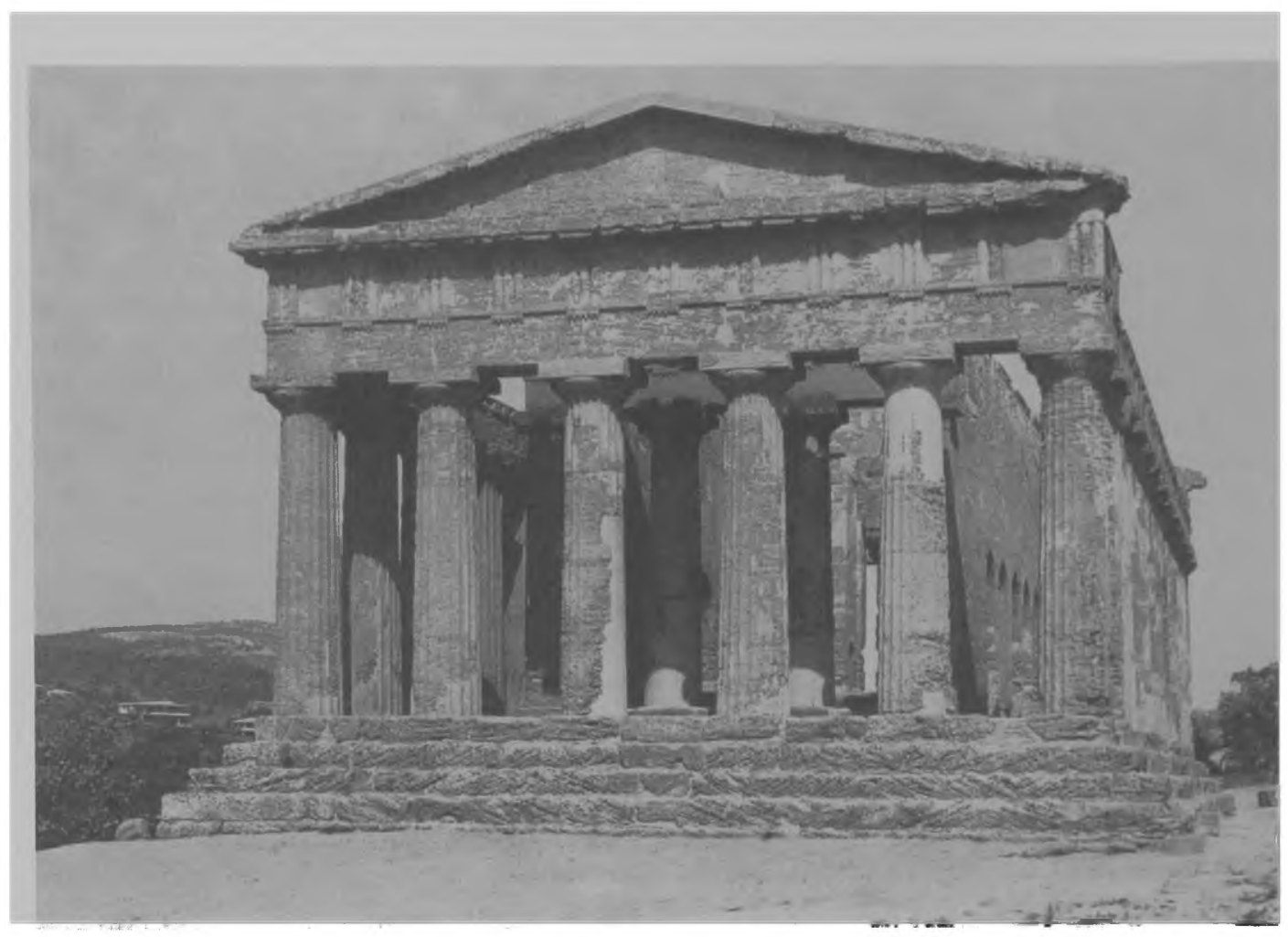

Fig. 13 - Vista externa do Templo da Concórdia, em Agrigento.

Fonte: MERTENS, D. Città e monumenti dei Greci d'Occidente. Roma: "L'Erma" di Bretschneider, 2006, p. 390.

O Athenaion de Siracusa e o Templo da Concórdia de Agrigento são exemplos da permanência de uma forma arquitetônica para um uso específico, que é o culto religioso. As mudanças no espaço nesses casos foram muito semelhantes, realizadas para adaptar os templos para seu uso por uma religião diferente da anteriormente cultuada nesse espaço. Ao observarmos as imagens e o relato de como foram feitas essas transformações, vemos que a adaptação dos templos para o seu uso como culto cristão, sob a forma de basílica, não exigiu mudanças drásticas. A partir desses dois exemplos podemos perceber que, assim como na basílica romana, a forma de basílica cristã já estava delineada também nos templos gregos.

Antes de retornarmos à análise das tabelas e ainda explorando a questão do uso da basílica para o culto cristão, gostaríamos de explorar, ainda que rapidamente, a questão da terminologia: o termo "basílica" é usado para designar tanto o edifício de reuniões e tribunal romano quanto uma igreja cristã, apesar de elas terem sido usadas em diferentes épocas para usos distintos, como já mencionamos. É correto afirmar que tanto o nome quanto a forma - essa com algumas alterações - permanecem, apesar da grande mudança sociopolítica e cultural que identificamos entre os períodos de construção e uso da basílica civil romana e da basílica cristã. O nome latino "basílica" tem sua origem no termo grego "basileu" que significa rei. Também associado a esse termo temos a palavra grega "basiléia" significando realeza. Durante o período bizantino, o termo basílica tem uma associação tão forte com seu uso como edifício de culto cristão que passa a ser sinônimo de igreja cristã. Desde esse período, época de estrutura- 
ção do cristianismo como religião e até os dias de hoje, a religião católica ainda é bastante difundida por todo o mundo. Principalmente no Ocidente, o tipo de estrutura de basílica ainda é bastante recorrente e o termo permanece como sinônimo de igreja católica. O uso da palavra "católico" no lugar de "cristão" na atualidade se explica pelo fato de que o catolicismo hoje é a sequiência linear desse cristianismo inicial, que deu origem a outras tantas religiões desde a época de sua criação até os dias atuais. Também aqui, a partir da informação de que a grande maioria das igrejas construídas no período estudado tem a forma de basílica, passaremos a entender e utilizar os termos basílica e igreja cristã como sinônimos.

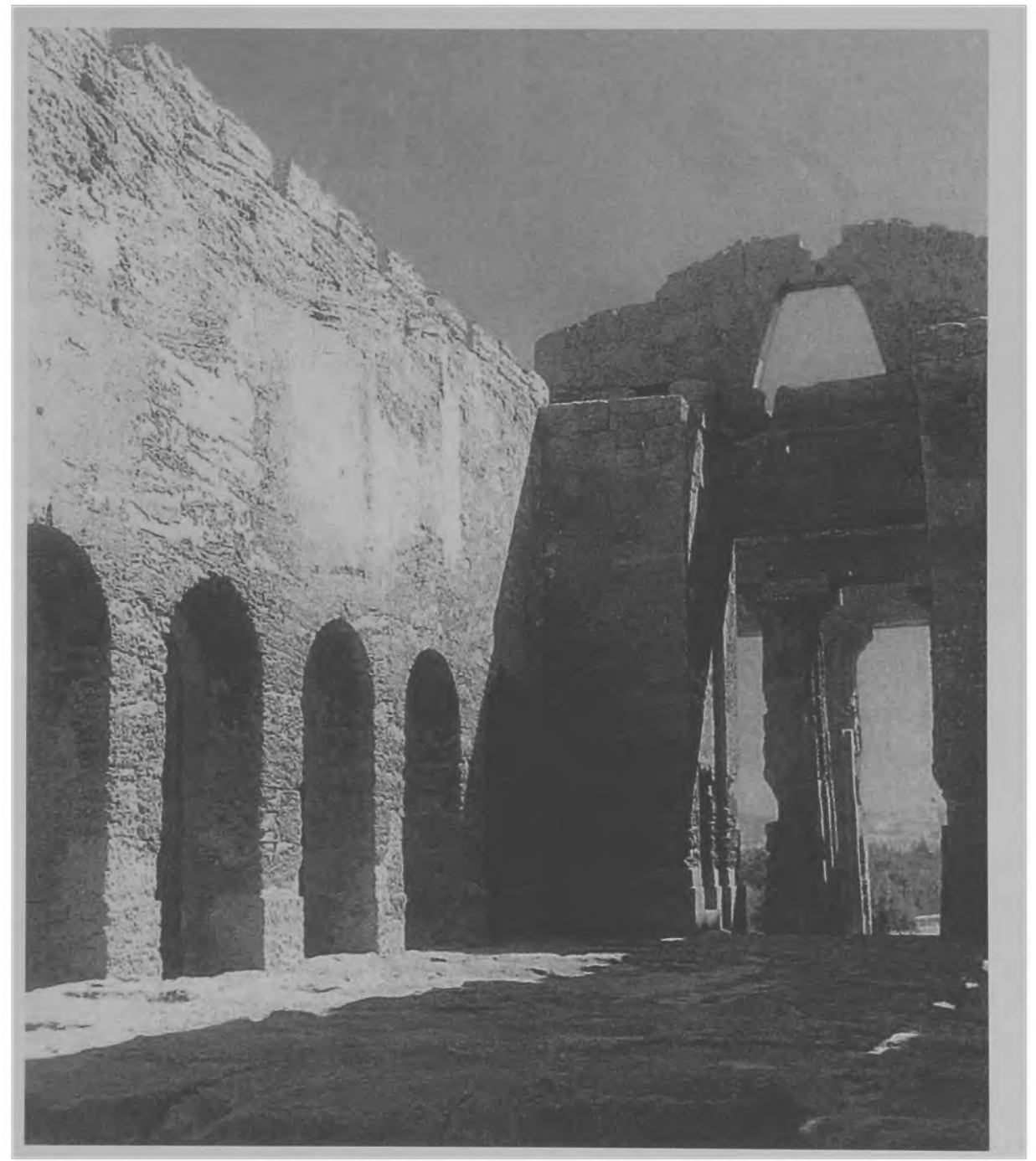

Fig. 14 - Vista da cela do Templo da Concórdia, em Agrigento.

Fonte: GRIFFO, P. Akragas - Agrigento: la storia, la topografia, I monumenti, gli scavi, p. 80. 
Retomando a análise formal, vemos que as igrejas que podem ser enquadradas no modelo de basílica padrão são compostas de três partes: uma nave central e duas laterais. Sua orientação procura na maioria dos casos se estabelecer no eixo Leste-oeste, onde o altar está posicionado a Leste e o acesso a Oeste. A abside, parte de forma usualmente semicircular que abriga o altar em uma igreja, pode assumir configurações variadas: monoabsidal, quando há apenas uma abside no lado Leste, podendo ou não ser ladeada por salas ou triabsidal, com uma abside central e outras duas laterais, normalmente divididas em correspondência com a divisão das três naves. Também podemos encontrá-las inscritas ou não em um edifício. A igreja de Ein 'Hanyia é um exemplo de basílica cristã em suas formas mais essenciais (Ficha XV), monoabsidal. Em Ostrakine encontramos mais um exemplo de basílica monoabsidal (Ficha LXXXI) enquanto em Elusa temos uma basílica triabsidal (Ficha XVI).

Apesar de ostentarem um formato padrão, que se resume à existência de três naves divididas por duas fileiras de colunas, as basílicas cristãs trazem variações em sua forma, que determinam alguns modelos. Os tipos de basílicas cristãs foram levantados a partir da elaboração do catálogo e sistematizados na tabela 2, da p. 151. Como essa tabela mostra, atestamos a existência de quatro tipos de basílicas - basílica, basílica com transepto, basílica monoabsidal e basílica triabsidal.

No tipo basílica foram listadas as igrejas descritas apenas como basílicas, não havendo nenhuma referência mais específica nem qualquer imagem que nos fornecesse uma informação mais precisa. $\mathrm{Na}$ descrição de algumas igrejas desse tipo é relatada a dificuldade de se determinar um tipo apropriado porque a abside não foi escavada ou porque, mesmo tendo sido, não foi possível identificar vestígios de uma estrutura triabsidal ou monoabsidal. Este é o caso da igreja de Kefar Truman (Ficha LVII), da Igreja de Santo Elias, em Kissufim (Ficha LVIII), do Edifício A de Magen (Ficha LXII) e da igreja de Roglit (Ficha LXXXVIII). A basílica aparece na tabela junto com seus subtipos porque representa uma porção de elementos do catálogo que, por falta de informação, não foi possível classificar por subtipos, tais como monoabsidal, triabsidal e com transepto.

A basílica com transepto é um tipo que tem, além das naves laterais, um espaço anexo a elas próximo à abside. Segundo a tabela 2 , a ocorrência desse tipo de basílica no catálogo foi de apenas um exemplar dentre as 93 igrejas identificadas com essa forma. A partir desses dados podemos inferir que esse foi um tipo de basílica muito pouco utilizado no período estudado.

O tipo de basílica triabsidal ocorre em $24 \%$ das igrejas, o que já configura um número relevante. Porém, segundo a tabela 2 (p. 151) o tipo de basílica mais utilizado é o monoabsidal, que é identificado em $59 \%$ das igrejas que compõe esse catálogo. A partir desses dados temos que, no local e período estudados, a basílica monoabsidal foi o tipo mais utilizado, seguido pela basílica triabsidal. Como estamos tratando de um período inicial, em que a forma de basílica romana original sofreu mudanças e passou a ser utilizada como edifício de culto pelos cristãos, podemos inferir que o modelo de basílica monoabsidal pode ter sido uma forma inicial que com o passar do tempo foi modificada e resultou na forma triabsidal, imbuídos da idéia de que uma forma mais simples tende a se tornar mais complexa à medida que o nível de complexidade da sociedade que cria tal forma também aumenta (Perring 1991:273). No caso dessas igrejas, verificamos que a partir do momento que a religião cristã se consolida, o ritual torna-se mais sofisticado, o que exige espaços mais especializados para abrigar as atividades que se desenvolvem nesse ambiente.

Temos como exemplo que confirma essa hipótese a Igreja da Natividade em Belém. A construção dessa igreja foi iniciada no ano 326 d.C., por ordem do imperador Constantino, sobre uma caverna onde a tradição aponta como local do nascimento de Jesus Cristo (Stern 1993:203-204). Como atualmente a igreja ainda existe, mas foi sucessivamente modificada ao longo de todos esses séculos de uso, foram realizadas escavações arqueológicas que nos revelaram como seria a igreja construída na época de Constantino (Ficha IX). Essa igreja tinha uma abside de forma octogonal, que estruturalmente é derivada dos mausoléus monumentais dos imperadores romanos, como o monumento a Dio- 
cleciano em Spalato. Segundo o relato de Eutéquio, patriarca de Alexandria entre 933 a 940 d.C., a igreja construída por ordem de Constantino foi muito danificada durante a revolta dos samaritanos, ocorrida no ano 529 , e por esse motivo foi reconstruída a mando de um outro imperador, Justiniano I.

Como a primeira igreja foi considerada pequena, em sua reconstrução as dimensões foram ampliadas: seu comprimento foi aumentado, mas a sua largura se manteve, pois apesar da nave central ter ficado mais larga as naves laterais se tornaram proporcionalmente mais estreitas. Essas modificações não alteraram sua estrutura básica, que per- maneceu com a forma de basílica. No lugar da abside octogonal do tempo de Constantino foi edificada uma tripla, cuja planta lembra uma folha de trevo (fig. 15). A Igreja da Natividade que existe na atualidade mantém a estrutura da época de Justiniano, isto é, do século VI d.C. Assim, a Igreja da Natividade é um exemplo de basílica construída em um primeiro momento, no século IV d.C., adotando-se o tipo monoabsidal e dois séculos depois, no século VI d.C., tendo sido destruída, foi reconstruída mantendo a forma de basílica tal como se apresentava antes, porém com uma grande mudança na abside, que passou a ser triabsidal.

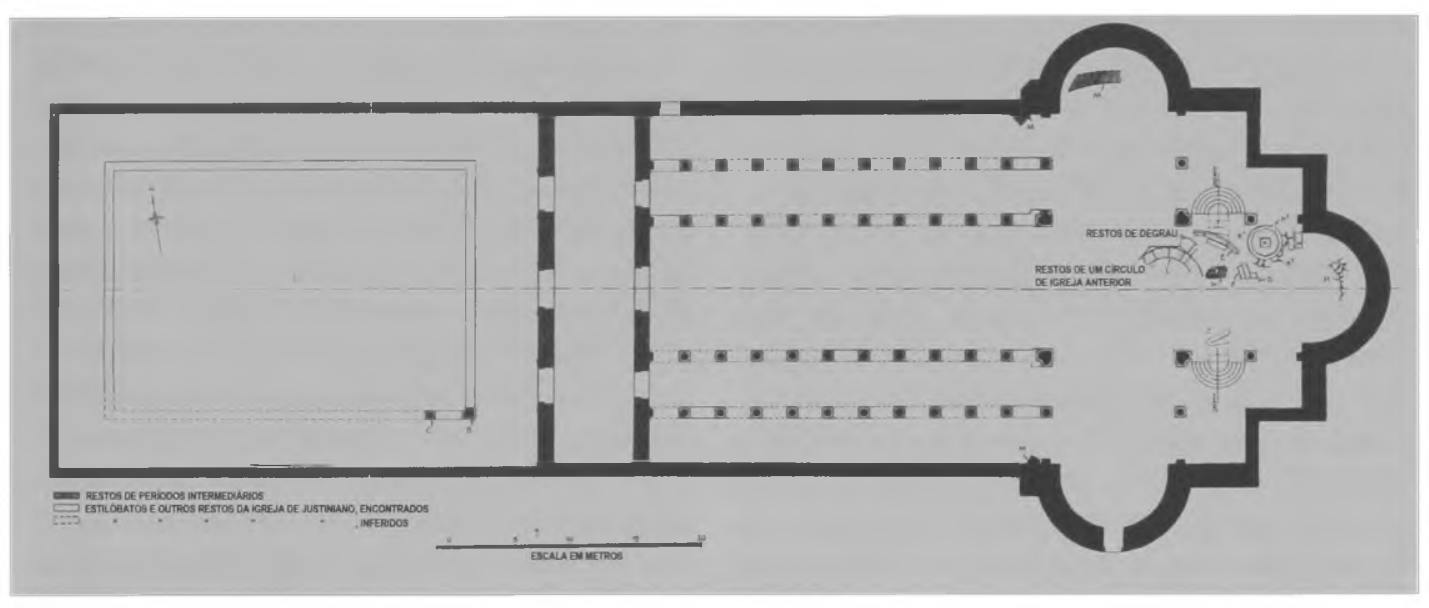

Fig. 15 - Igreja da Natividade, Belém, no tempo de Justiniano

Fonte: TSAFRIR, Y. Ancient Churches Revealed, p. 7.

Vale notar que a Igreja da Natividade, juntamente com a Igreja do Santo Sepulcro em Jerusalém (Ficha XLVIII), são duas basílicas que diferem do restante do catálogo, porque ambas têm duas naves laterais de cada lado da nave central enquanto os outros exemplos estudados apresentam duas laterais, uma de cada lado da nave central. Além disso essas duas igrejas mostram outras peculiaridades na sua forma que as diferem das outras estruturas estudadas. No caso da Igreja da Natividade, como já mencionamos, a estrutura monoabsidal octogonal, que difere da forma em semicírculo usual, foi substituída posteriormente por uma abside tripla em forma de trevo, não-usual. $\mathrm{O}$ que identificamos a partir dos exemplos que constam do catálogo é que nas igrejas triabsidais, as absides são semicírculos.

A Igreja do Santo Sepulcro por sua vez caracterizou-se desde a época bizantina por ser um complexo composto por diversos edifícios. As quatro estruturas principais que fazem parte desse complexo são: o átrio da basílica, localizado a Leste da basílica, a basílica em si (Martyrion), o átrio da rotunda, conhecido como o Jardim Santo, e a rotunda (Anastasis). Todo esse complexo media $130 \mathrm{~m}$ de comprimento e $60 \mathrm{~m}$ de largura (Stern 1993:779-781). 
Stern justifica as peculiaridades desses edifícios: "Essas duas Igrejas também são muito maiores que outras Igrejas em forma de basílica encontradas na Palestina; elas provavelmente não serviam apenas para oração e outros propósitos rituais, mas também tinham a intenção de atrair tantos peregrinos quantos fossem possíveis (da Palestina e de outras procedências) para os lugares sagrados associados ao nascimento, vida e morte de Jesus" (Stern 1993:305). Acreditamos que esta é uma justificativa plausível e que explica as dimensões maiores e as peculiaridades encontradas nas formas arquitetônicas da Igreja da Natividade e na do Santo Sepulcro.

Retomando a hipótese lançada - de que a basílica triabsidal seria o resultado de uma mudança posterior no tipo de basílica monoabsidal - para comprovar sua validade não podemos nos restringir a apenas um exemplo, mesmo porque, como foi explicado, este representa um caso muito peculiar de igreja cristã. Dessa forma, retornamos ao catálogo para elaborar um detalhe dos tipos e subtipos de igrejas por época, o que resultou nas tabelas 3 e 4 , na p. 152 . Um primeiro dado a ser comentado, presente na tabela 3 , na p. 152 , é que dentro do recorte temporal estudado, que tem início no século IV e final no século VI d.C., houve um crescimento na construção de igrejas em cada século; o número cuja construção é datada do século $\mathrm{V}$ d.C. é cerca de $50 \%$ maior do que as que existiam no século IV d.C., estando entre esses dois séculos a diferença mais significativa em números.

Na tabela 4, na p. 152, na qual se detalha o tipo de igreja encontrado em cada um dos três séculos estudados, foram identificadas duas situações interessantes: a primeira é que o número de igrejas monoabsidais permanece $o$ mesmo entre os séculos V e VI d.C.; no intervalo anterior, entre os séculos IV e V d.C., observa-se um aumento de $33 \%$ na construção desse tipo de igreja, seguindo a tendência de crescimento dessas construções em geral para esse período. Porém, esse aumento entre os séculos V e VI d.C. atestado nas igrejas em geral, ainda que em escala menor do que o identificado para os séculos IV e V d.C., não se verifica no caso das basílicas monoabsidais, cujo número se repete entre os séculos V e VI d.C. A segunda situação explicitada na tabela 4 (p. 152), diz respeito ao tipo de basí- lica triabsidal. Para esse tipo, verifica-se que não houve crescimento, e sim um decréscimo entre os séculos IV e V d.C., contrariando a tendência geral de crescimento atestada na tabela 3 (p. 152); por outro lado, o número de basílicas triabsidais do século VI d.C. é o dobro do existente no século $\mathrm{V}$ d.C., mostrando um aumento bem superior ao atestado para as igrejas em geral.

Apesar de um aumento significativo da existência de basílicas triabsidais no período mais posterior do recorte da pesquisa - o século VI d.C., superando até a tendência de aumento das igrejas em geral, a hipótese lançada anteriormente não se confirma, uma vez que a existência do tipo "basílica monoabsidal" se manteve entre os séculos V e VI d.C. Para que a hipótese de que o tipo de basílica monoabsidal tivesse sido gradativamente substituído pelo tipo triabsidal fosse válida, os dados teriam que nos mostrar um decréscimo na ocorrência de igrejas monoabsidais com o passar dos séculos em prol do aumento das basílicas triabsidais. Além da Igreja da Natividade, a Igreja Norte de Sobata (Ficha XCVI) também é um exemplo onde a substituição do tipo monoabsidal pelo triabsidal pode ser atestada. Além dessas igrejas, podem até existir outros casos em que ocorram a mesma situação e que não foram relatados, mas os dados apresentados nas tabelas 3 e 4 (p. 152), mostram que não podemos interpretar essa tendência como regra geral. Por outro lado, o crescimento na ocorrência de basílicas triabsidais no século VI d.C. é um indício de que a nossa hipótese a respeito da demanda por espaços mais especializados que se configura a partir da sofisticação do ritual cristão é válida.

A tabela 4 (p. 152) ainda nos mostra que os tipos de igreja identificados estão presentes nos três séculos nos quais concentramos nossas pesquisas; não notamos nessa tabela nenhum tipo que se destacasse em apenas um século, que poderia ser mencionado como característico de alguma fase do período bizantino.

No que diz respeito à posição dessas igrejas em relação aos pontos cardeais, isto é, a sua orientação, a grande maioria dos edifícios em que esse dado foi posto a disposição - cerca de $92 \%$ do total - estão estabelecidos na posição Leste-oeste, tendo o altar localizado a Leste e a entrada do edifício a Oeste. Esses 
dados são apresentados na tabela 5 da p. 153 Para cerca de metade das igrejas do catálogo esse dado não estava disponível, mas partindo da grande ocorrência daquelas posicionadas na direção Leste-oeste podemos inferir que essa orientação era uma regra a ser seguida, podendo, como em qualquer regra, haver exceções. Talvez por ser considerada assim, e por isso já subentendida, os autores não tenham visto a necessidade de informar a orientação quando descrevem a igreja. $\mathrm{Na}$ realidade em poucos registros essa informação vinha escrita; para a maioria dos casos a orientação da igreja foi extraída a partir do seu desenho em planta, onde sua posição é representada em relação ao norte. No texto de Asher Ovadiah a respeito das primeiras igrejas vemos a importância da sua posição em relação aos pontos cardeais: no momento em que ele descreve os elementos essenciais presentes nesse espaço e suas funções, ao apresentar a abside ele a define como "um nicho semicircular na extremidade leste $^{4}$ de uma igreja." Esse mesmo autor descreve o nártex como "um corredor que se estende por toda a largura do edifício, no lado oeste ${ }^{5}$ da igreja, em frente à entrada." (Ovadiah 1993:307)

Complementando a tabela 5 (p.153), desenvolvemos as tabelas 6 na p. 153 e 7 na p. 154, nas quais detalhamos a orientação das igrejas por séculos e tipos, respectivamente. A tabela 6 na p. 153 nos mostrou que a orientação se manifesta de maneira uniforme ao longo dos três séculos estudados, e que nenhum deles é marcado por uma orientação específica. Na tabela 7 , na p. 154 , a orientação está diluída nos diversos tipos de igreja identificados, e lá vemos que nenhum tipo de orientação se relaciona com apenas um modelo de igreja, configurando-se como uma característica própria desse tipo.

A importância da orientação nas igrejas cristãs é um dado que pode ser notado também naqueles dois exemplos de templos gregos que foram posteriormente transformados em basílicas, o Athenaion de Siracusa e o Templo da Concórdia de Agrigento, já descritos nesse capítulo. Nesses dois casos uma parte importante da adaptação para igreja cristã envolveu a mudança na orientação do templo. Assim como

O grifo é nosso.

idem. as igrejas, os templos gregos costumavam ser orientados na direção Leste-oeste, mas nesses casos sua entrada ficava a Leste, lado onde nasce o sol e que dava acesso à cela, parte mais importante do templo, onde ficava a estátua de culto no interior e o altar, na parte externa do edifício. Nas igrejas, como já vimos, a entrada ficava a Oeste e no Leste, na abside, estava o altar, o ponto central do culto cristão e onde ocorre o sacrifício, momento em que o celebrante consagra pão e vinho em corpo e sangue de Jesus Cristo. Deste modo na transformação dos templos gregos em igrejas a mudança da orientação da entrada é um ponto essencial, necessária para que o espaço se configure da maneira mais adequada ao culto cristão. Ao mesmo tempo em que é uma mudança, a questão da orientação nesses casos do reaproveitamento do espaço dos templos gregos em igrejas cristãs é também uma permanência, na medida em que mantém o altar, lugar onde se realiza o sacrifício, a Leste no edifício, revelando a importância da sua localização para as sociedades que fizeram uso desse edifício em diferentes tempos históricos.

Um outro aspecto a respeito das basúlicas cristãs e a sua proporção. Vitrúvio estabelece para as basílicas civis romanas que a sua largura deveria estar entre $1 / 3$ e a metade do comprimento (Vitrúvio 1999:21). A fim de verificar se essa proporção estabelecida por Vitrúvio para as basílicas romanas é adotada também no caso das cristãs, elaboramos uma tabela de dimensões, de onde obtivemos as proporções ao dividir a largura pelo comprimento. Se a proporção das igrejas cristãs seguisse aquela estabelecida, por Vitrúvio, o índice deveria ficar entre 0,33 e 0,5 . Porém, o que a tabela 8 (pp. 154-156), sobre as proporções das basílicas cristãs, nos mostra é que em grande medida a sua relação proporcional não seguiu o que foi determinado por Vitrúvio. De um total de 73 igrejas que têm suas dimensões conhecidas, somente 9 , o que corresponde a $12 \%$ do total, estavam dentro da faixa estabelecida por ele. A grande maioria dessas igrejas está na faixa de proporção entre 0,50 e 0,75 ( $56 \%$ do total), o que significa que, em relação ao comprimento, a largura dessas igrejas está maior do que o que era usualmente adotado para as basílicas roma- 
nas. Lembrando que Vitrúvio pode estar descrevendo as proporções ideais para a basílica romana e que seu relato pode não corresponder às situações reais, recorremos aos exemplos aqui apresentados para conferir se essa divergência poderia ser notada visualmente, pela observação de suas representações em planta. Comparada às basílicas cristãs do catálogo percebemos que o edifício romano é de fato mais longilíneo. O que pode ser identificado a partir desses dados é que entre a basílica civil romana e a cristã, mesmo apresentando características em comum, que denotam uma permanência da sua forma apesar da mudança no uso, também podem ser identificadas certas descontinuidades que revelam que cada um desses edifícios tem características próprias. Se pensarmos na maneira como o culto cristão se realiza, vemos que o espaço da nave é ocupado pela assembléia, que assiste à celebração que o sacerdote realiza. O altar é o ponto focal do ritual, é o lugar para onde os cristãos se voltam no momento do culto. Dessa maneira, podemos deduzir que a ocorrência de formas mais largas em relação ao seu comprimento nas basílicas cristãs é uma adaptação que tem como objetivo melhorar as condições de visualização do altar a partir de quem está na nave.

Em resumo, apesar de seguirem na sua forma básica um modelo existente, fixo na memória dos povos que viveram sob dominação romana, não se desenvolveu um desenho único para as igrejas que adotaram a forma de basílica, quer dizer, não existiu um padrão que tivesse sido rigorosamente seguido, nem houve uma continuidade muito estrita da forma de basílica anterior.

Quanto aos aspectos formais, os exemplos de igreja apresentados mostram que a forma de basílica permaneceu, com algumas alterações. De maneira diversa das romanas, onde a entrada localiza-se usualmente em um de seus lados maiores, nas igrejas que adotaram a forma de basílica a entrada se dá por um dos lados menores, na maioria das vezes posicionado a Oeste e o altar, lugar de destaque em uma igreja, é colocado no lado oposto à entrada, a Leste, em uma abside, posição onde se localizava o tribunal nos edifícios romanos. A proporção também mudou: as basí- licas cristãs são mais largas que as romanas em relação ao seu comprimento. Além disso, observamos em muitas igrejas que compõem o catálogo que elas têm salas anexas aos lados maiores das basílicas; usualmente eram ambientes que abrigavam funções acessórias ao culto religioso, como capelas, batistérios e diaconicons. Apesar de todas as variações formais identificadas nas igrejas, a essência da forma da basílica permaneceu.

São essas alterações que nos mostram que, apesar de assimilada, a basílica enquanto forma foi reinventada pela civilização bizantina. Entendemos esse fenômeno de assimilação e reinvenção da memória de um edifício como parte de um processo de mudança da mentalidade e necessidades de um povo, que se expressa no surgimento de uma nova forma arquitetônica característica de sua época - a igreja, que preserva um modelo antigo, acrescentando a ele certas inovações (Perring 1991; Rapoport 1982).

A tabela 9, da p. 157, trata da ocorrência de capitéis e seus tipos nas igrejas que compõe o catálogo. Apesar de comprovar a escassez de informação encontrada a esse respeito, revelada pela falta de dados sobre esse elemento arquitetônico para 93\% das igrejas estudadas, achamos relevante comentá-los. Como mencionamos anteriormente, o catálogo de igrejas presente nessa dissertação foi elaborado a partir dos registros arqueológicos encontrados em duas obras: a TNEAEHL (1993) e a ACR (1993), que trazem basicamente a configuração das igrejas em planta, pois muitas daquelas que foram escavadas haviam sido destruídas. São poucas as que têm alguma informação sobre sua altura, fachada, colunas e capitéis, enfim, sobre seu volume interior e exterior.

Ainda no projeto de pesquisa consideramos os capitéis como elementos decorativos que poderiam nos fornecer informações de valor a respeito da permanência e reinterpretação de componentes da arquitetura clássica em uma nova situação - as igrejas, construídas para a realização de rituais do cristianismo, uma religião que havia se difundido no século IV d.C., o limite inicial de nosso recorte temporal. Por esse motivo, apesar dos poucos dados que se revelaram a esse respeito, optamos por apresentá-los e comentá-los 
mesmo assim. Nos parcos $7 \%$ das igrejas onde o estilo do capitel é claramente informado, a maior parte é do estilo coríntio e apenas em uma igreja, em Horvat Beth Loya (ficha VII) o capitel é classificado como de "face plana" Em virtude dos dados escassos fomos buscar maiores informações nas obras de referência. No texto sobre as igrejas paleocristãs, Asher Ovadiah (1993:308) apresenta uma descrição geral a respeito da ornamentação encontrada nesses edifícios. Nessa descrição o autor afirma que capitéis decorados foram encontrados em algumas igrejas apresentadas pela enciclopédia, a maioria deles no estilo coríntio de época bizantina - eram capitéis que apresentavam o motivo de cruz esculpido em meio à decoração tradicional do estilo coríntio, sendo que a cruz foi uma alteração característica do período bizantino.

O capitel coríntio foi inventado na Grécia no final do século V a.C., como um substituto mais trabalhado do jônico, em uma época caracterizada pela importância atribuída à parte ornamental. Esse tipo de capitel tem a forma de um sino invertido, coberto de rebentos e folhas de acanto, planta que parece brotar do cimo do fuste. Como ilustração, apresentamos aqui os capitéis coríntios do templo de Zeus Olímpico, em Atenas (fig. 16). Esse é um templo colossal que, originalmente construído na ordem dórica, nunca foi terminado. Um dos reis helênicos, Antióquio IV, contratou Cossutius, um arquiteto romano, para reconstruí-lo no ano 174 a.C. na ordem coríntia, mais moderna. Nesse capitel se confirmam as características clássicas dessa ordem, das quais encontraremos eco até mesmo nas cópias da época de Adriano produzidas para ampliar esse mesmo templo. Por toda a sua volta, o capitel é pesadamente carregado de folhas de acanto dispostas em duas altas coroas de onde saem em um nível superior folhas que acompanham as volutas laterais. No centro, emergindo de seus caudículos rígidos, opõem-se duas volutas decorativas que dominam a depressão mediana do ábaco. Solidamente mantida na base do capitel por um filete liso, o cesto de acanto sustenta com força as quatro volutas angulares que suportam o ábaco.

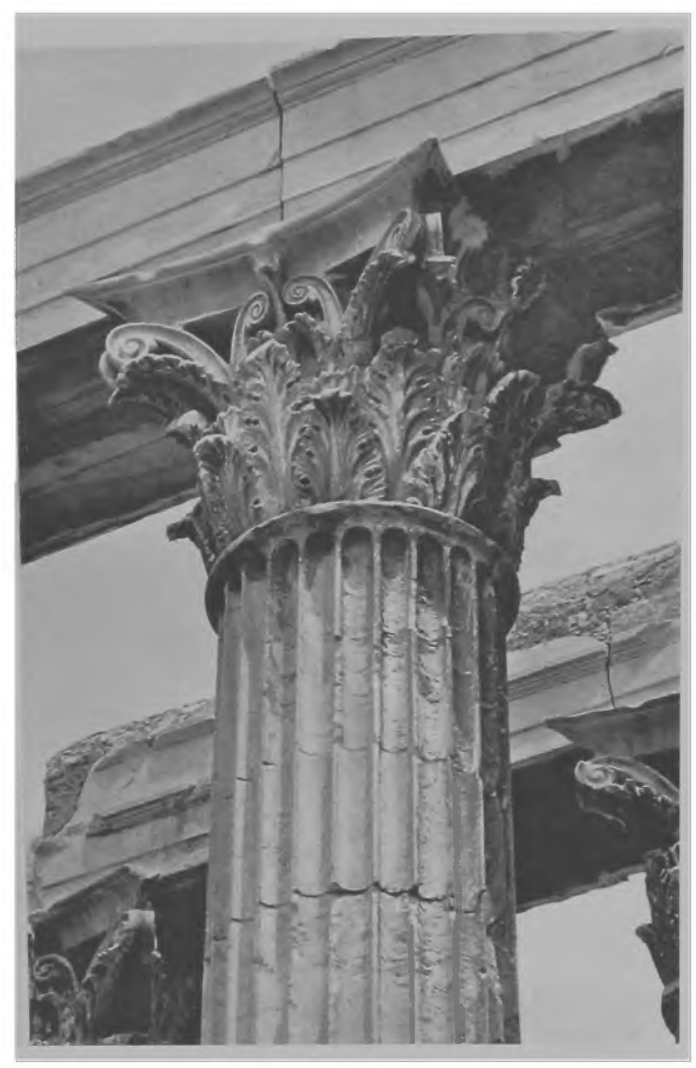

Fig. 16-Detalhe do capitel templo de Zeus, Atenas

Fonte: CHARBONNEAUX, J. Grèce Hellénistique, p. 26.

No início, o capitel coríntio era utilizado apenas na decoração de interiores, mas um século depois ele passa a substituir o capitel jônico no exterior dos edifícios. $\mathrm{Na}$ arquitetura grega o capitel coríntio resolveu nas colunadas do peristilo, particularmente nos ângulos, problemas deixados em suspenso pelo capitel jônico, muito alongado, exclusivamente biface, particularmente inadaptado nos cantos, local onde se desenvolvia a articulação do entablamento. $\mathrm{Na}$ época romana, tornou-se o capitel padrão para quase todos os fins (Janson 1992:127). O primeiro exemplo conhecido de utilização desse tipo de capitel está no interior do bem preservado templo de Apolo em Bassai, na Arcádia, datado do século $\mathrm{V}$ a.C.

$\mathrm{Na}$ igreja da Natividade os pilares de época paleocristã se preservaram, e foi por meio deles que conseguimos obter várias informa- 
ções a respeito dos capitéis de época bizantina. Nessa igreja os pilares de mármore branco com veios rosados são coroados por capitéis de estilo coríntio, acrescidos de uma cruz grega sobre cada feixe de folhas de acanto (fig. 17) (Stern 1993:208). Mencionamos anteriormente que Asher Ovadiah já havia atentado para a existência de motivos de cruz como um acréscimo de época bizantina à decoração dos capitéis nas igrejas cristãs e assim, os dados obtidos a esse respeito na igreja da Natividade nos trazem um exemplo dessa tendência. A adição da cruz grega ao capitel de estilo originalmente grego e o fuste liso, sem caneluras, são exemplos de como os elementos da arquitetura greco-romana foram reinventados nas edificações bizantinas, com as adaptações demandadas pela nova religião.

Uma característica presente nas igrejas, inclusive nesse exemplo, que marca sua diferença em relação à arquitetura religiosa grega e que merece ser destacada é o posicionamento das colunas no edifício. Enquanto na arqui-

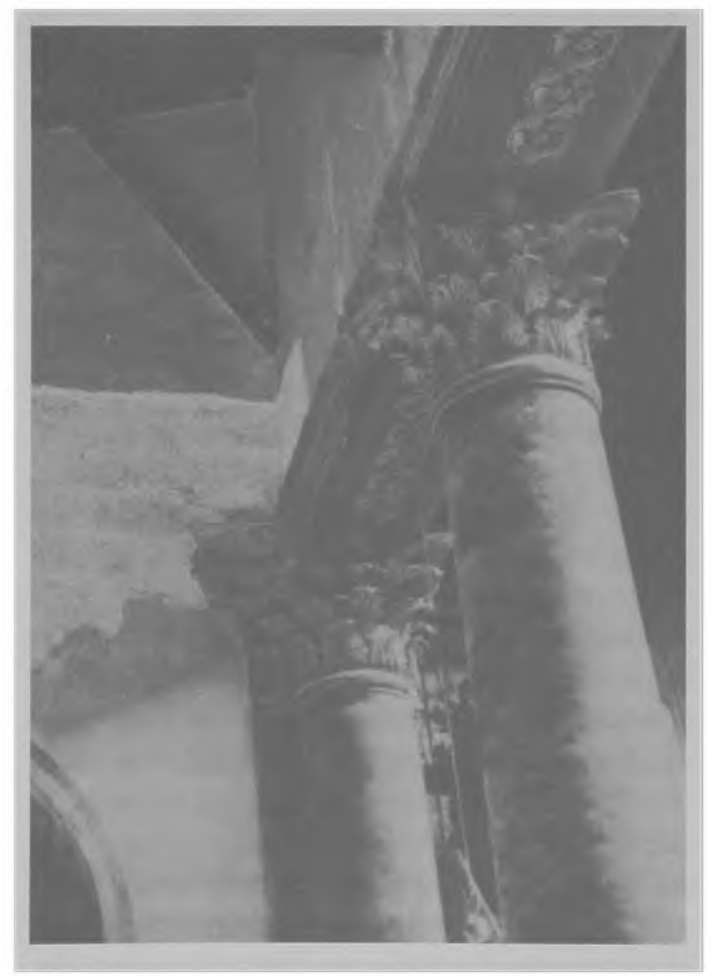

Fig. 17 - Detalhe das colunas - Igreja da Natividade, Belém.

Fonte: STERN, E. (ed.) TNEAEHL, p. 207. tetura grega as colunas marcam o exterior do edifício, estabelecendo o limite entre o espaço construído e o não construído, desde as primeiras igrejas a colunada passa para o seu interior. Com essa mudança, a percepção da monumentalidade da obra, que já era percebida do lado de fora, no espaço urbano, passa para o interior das construções. Retomando os casos do Athenaion de Siracusa e do Templo da Concórdia de Agrigento, vemos que uma das mudanças realizadas no momento em que eles se tornam igrejas é o preenchimento do intercolúnio externo, de forma que o espaço entre a colunada externa e a cela é transformado em naves laterais e passa a ser ligado a ela por meio de aberturas em suas paredes, e assim passa a fazer parte do interior da igreja. Juntamente com a mudança na orientação, o fechamento do intercolúnio externo são as principais mudanças empreendidas no espaço desses templos para que eles passem a ser igrejas, tornando-se adequados à realização do ritual cristão.

O resultado dessa nova configuração do espaço, característica da arquitetura bizantina e que se vê presente nas primeiras igrejas, é a sua aparência exterior simples e severa, com maior riqueza de detalhes e dramaticidade concentrando-se no seu interior, materializando um contraste entre a arquitetura paleocristã e a clássica (figs. 18 e 19).

Entendemos essa mudança da colunada, marca do monumental, do exterior para o interior do edifício também como uma resposta material à transformação da mentalidade. É um tipo de comunicação não-verbal que nos informa que a maneira de pensar da sociedade que produziu essa mudança não é mais a mesma. $\mathrm{Na}$ passagem para o período bizantino os indivíduos despojaram-se de certos valores para adotar outros em seu lugar, revelando um momento de mudança em vários aspectos - político, econômico, social e cultural - da vida dessa sociedade. Dentro do contexto do estabelecimento de uma nova religião não se deve ignorar a questão do ritual, que também marca a relação dos indivíduos com o espaço na qual ele se realiza. Os dois templos gregos apresentados nesse capítulo, ao serem transformados em igrejas entre os séculos VI e VII d.C., sofreram alterações no seu espaço construído para que se 


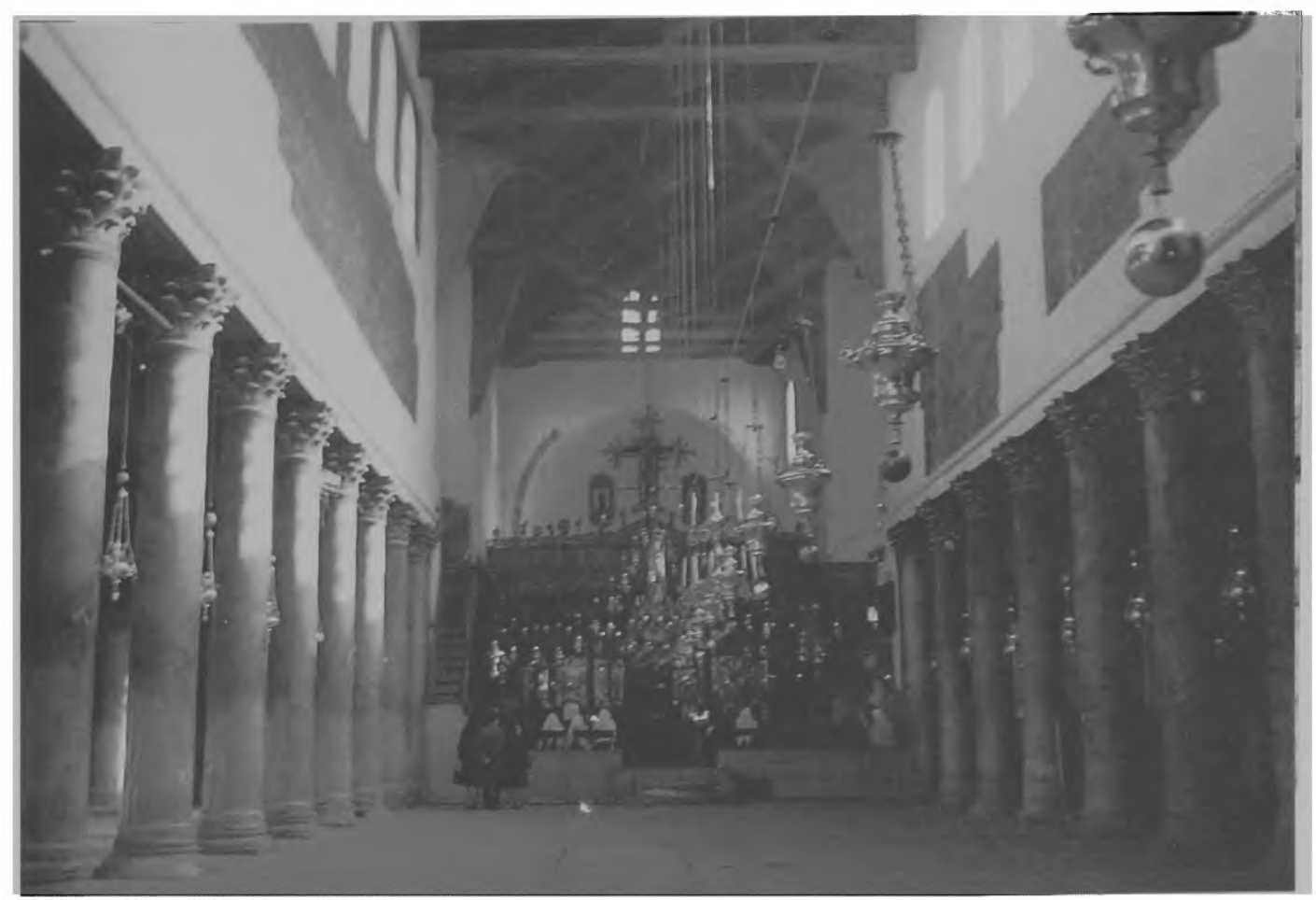

Fig. 18 - Vista do interior - Igreja da Natividade, Belém.

Fonte: TSAFRIR, Y. Ancient Churches Revealed, prancha I-A.

tornassem adequados ao novo ritual. Na cultura grega o ritual religioso não ocorre dentro do templo, mas fora dele, no altar que se posiciona à Leste, na sua entrada. O edifício do templo na Grécia é a morada do deus, lugar onde a estátua de culto fica abrigada, assim como as suas oferendas. Na religião grega o sacrifício é um ato coletivo, que se realiza no altar fora do templo. Esta é uma crença onde a figura do intermediário não é importante, e os indivíduos podem se reportar diretamente aos deuses. No caso da religião cristã, o edifício religioso, que é a igreja, assim como nas sinagogas no caso do judaísmo, é um local destinado à reunião de seus seguidores, onde o ritual era realizado em um espaço próprio para esse fim - o altar, que assim como nos templos gregos, está posicionado a Leste, na abside da igreja, mas de maneira diversa da grega, fica no interior do edifício e não fora dele. No cristianismo, os rituais são realizados pelo sacerdote, que é a figura intermediária na relação entre os cristãos e o seu Deus, responsável pela realização do sacrifício que estabelece o contato do indivíduo com a esfera divina. Apesar de ser realizado em um espaço que propicia a reunião, o ritual cristão é bastante individualizado e baseado no recolhimento. A celebração é na igreja, lugar onde os cristãos se reúnem para ouvir o sacerdote e dele receber a comunhão; não deve haver interação entre os indivíduos, mas silêncio e recolhimento para que todos ouçam Deus, representado ali pelo sacerdote. Como pode se perceber, a maneira como seus deuses são reverenciados difere enormemente no ritual grego e no cristão, e essas diferenças vão se expressar também na forma construída.

O uso da basílica como modelo nas igrejas protocristãs é uma questão que merece ser explorada para além das considerações sobre sua reutilização formal. A pergunta que guia nossas explorações a partir desse momento é: por que a basílica, entendida como uma estrutura utilizada para reuniões civis e políticas em 


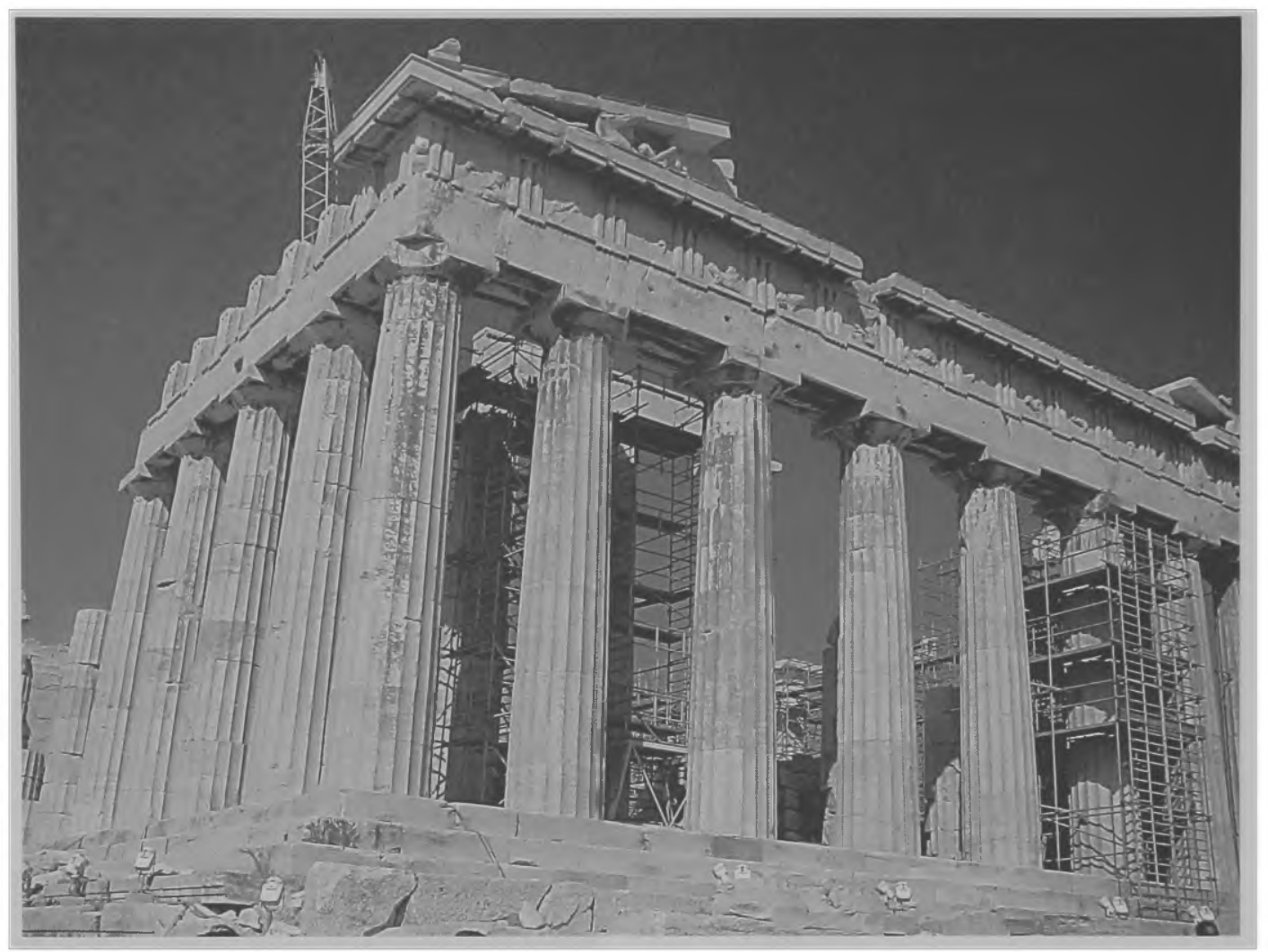

Fig. 19 - Vista do Pártenon, Atenas.

Fonte: Arquivo pessoal, set./2006.

época romana foi adotada no período bizantino para o culto religioso, um uso totalmente diferente do período anterior?

Já mencionamos que a igreja é um espaço que se configurou da melhor maneira possível para atender às necessidades criadas pelo culto cristão, no qual a assembléia se reúne para assistir ao ritual, que é realizado por um sacerdote. Nesse sentido podemos interpretar o uso da basílica como a forma conhecida por esses indivíduos mais adequada para a reunião de uma grande quantidade de pessoas em um mesmo local e por isso o seu uso como edifício religioso no período bizantino.

Porém, a leitura do texto de Duncan (1990) nos indica que pode haver alguma coisa além do simples aproveitamento da forma de basílica pela sua característica apropriada para locais de reunião. Como já foi mencionado no capítulo 1 deste trabalho esse autor busca eviden- ciar que o espaço construído, além de reproduzir aspectos da vida social, pode também evidenciar a constituição ou até mesmo a contestação das relações de poder que nele se estabelecem. Tendo isso em mente, buscamos observar a situação político-econômica e social que se estabelece juntamente com a construção dessas igrejas, a fim de verificar se a forma de basílica, além de adequada aos propósitos da religião, também se configura como materialização dos interesses de um grupo dominante.

Esse questionamento nos remete à figura de Constantino, pois segundo os relatos históricos, foi a partir da sua tolerância e incentivo que o cristianismo se expandiu e iniciou a construção de igrejas. Como vimos anteriormente, no capítulo 2 deste texto, a primeira situação em que Constantino demonstrou sua simpatia ao cristianismo foi em outubro do ano 312 d.C., quando ele venceu a batalha da ponte Mívia 
contra Maxêncio e atribuiu a vitória ao fato de, orientado por um sonho, ter escrito as iniciais Chi-Rho, signo de Cristo, nos escudos de seus soldados. A respeito desse episódio há uma discussão entre os historiadores do período se a atitude de Constantino foi uma expressão sincera de sua convicção religiosa ou uma questão de visão política. Com a vitória contra Maxêncio ele se torna o único governante da porção ocidental do Império Romano. Pouco depois, em abril do ano 313 d.C., Licínio vence Maxímio Daia em uma batalha no Campo Ergeno, na Trácia, tornando-se o único governante da parte oriental do império.

Pouco depois, Constantino e Licínio, os dois imperadores, encontrando-se em Milão, fazem um acordo para adotar a mesma orientação religiosa nas duas partes do Império Romano, a oriental e a ocidental. Os termos desse acordo foram expressos no documento conhecido por Édito de Milão. Esse documento orientava os governantes das províncias romanas a cessarem com a perseguição aos cristãos, a restauração para todos os cidadãos da propriedade cristã confiscada, fosse ela individual ou coletiva, e que não apenas os cristãos mas também os seguidores de outras religiões se sentissem livres para praticá-las.

Constantino já mostrava simpatia aos cristãos antes do ano 312 d.C., mas foi nessa época que ele se comprometeu pessoalmente com a fé cristã. Sua ligação com o Cristianismo não foi vista apenas na ocasião da batalha da ponte Mílvia, mas também quando, no mesmo ano, o imperador se recusou a realizar os sacrifícios tradicionais no monte Capitólio, apesar desse ritual fazer parte da entrada triunfal dos imperadores na cidade de Roma.

Por outro lado, Constantino ainda mantinha o cargo de pontífice máximo, decerto para agradar a nobreza senatorial que em grande parte era pagã. É válido também destacar que no famoso arco triunfal erigido em sua honra pelo senado, cuja construção foi finalizada no ano 315 d.C., não existem símbolos cristãos, e sua decoração é neutra no que diz respeito a religião. Os símbolos cristãos também demoram a aparecer nas suas moedas.

Outra questão diz respeito ao seu batismo. Segundo as fontes históricas, tais como Eusébio de Cesarea (1994:384), Constantino foi batizado logo antes de sua morte, no ano 337 d.C. Para autores como Pohlsander (2004:
27) este dado não pode ser visto como falta de sinceridade ou comprometimento com a religião, pois como a sua prática não era encorajada pela igreja, os cristãos dos séculos IV e V d.C. normalmente atrasavam o seu batismo até a velhice.

Mas, como esse mesmo autor destaca, a decisão tomada por Constantino no ano 312 d.C. a respeito da religião vai estar presente de forma marcante nos próximos 25 anos em que ele viveu e governou. Longe de ser um assunto privado, a opção religiosa adotada por Constantino afetou profundamente tanto a igreja cristã quanto o Estado, a religião e a política do mundo romano. "Religião e política eram, de fato, intimamente relacionadas no mundo romano, assim como eram no mundo grego. Mudanças em um setor inevitavelmente levavam às mudanças no outro" (Pohlsander 2004:29). Acreditamos na lógica da afirmação de Pohlsander e partindo desse pressuposto atentamos para a relação entre as atitudes de Constantino no campo da religião e suas realizações políticas.

Nos 300 anos de sua existência antes de Constantino, o cristianismo foi por várias vezes objeto de perseguição; ao mesmo tempo, ele desfrutou de independência. "A partir do seu ativo envolvimento nos seus assuntos, mesmo que benevolente, Constantino destituiu a igreja de sua independência. Ele se consagrou não apenas o soberano por escolha divina mas também um $k o$ nos episkopos (bispo comum), isto é, observador geral e árbitro das questões da igreja. Ele usou a igreja como instrumento de política e impôs sobre ela sua ideologia imperial. Seu desejo de harmonia e unidade na igreja foi considerado prioridade sobre todas as outras considerações. A igreja era agora claramente obrigada a adotar uma atitude diferente em relação ao império, à autoridade do governo e ao serviço militar. A partir do momento em que bispos assumiram algumas funções judiciais e administrativas a igreja não apenas endossou mas passou a fazer parte do aparato do governo" (Pohlsander 2004:29-30). Foi a partir do governo de Constantino, momento em que ela passa a fazer parte do Estado, que a igreja adquiriu poder e riqueza. A nosso ver, Constantino percebeu na adoção do cristianismo uma situação favorável à sua vontade de dominar todo o Império Romano mais do que uma devoção sincera à nova religião. As duas posturas, religiosa e po- 
lítica, estão intimamente relacionadas e por esse motivo as suas ações nessas duas áreas devem ser entendidas em conjunto. Não é possível ver essa situação somente de um lado, seja ele o comprometimento religioso de Constantino ou sua visão política, como sugerem alguns historiadores, mas sua atuação deve ser entendida, dada sua complexidade, sob ambos os aspectos.

Como resultado do posicionamento de Constantino, vemos que o império foi afetado não apenas em sua estrutura e nas suas instituições, que permaneceram quase intactas, como também no fundamento de suas ideologias. Constantino se tornou o fundador do Império Cristão, e como imperador era o representante de Deus na terra. Durante o período em que governou sobre o Império Romano, esse imperador manteve muitas das suas instituições tradicionais, como o Senado. Como vimos anteriormente, no capítulo 2 desta dissertação, quando no ano 330 d.C. Constantino funda a cidade de Bizâncio como nova capital do Império, ele leva para lá muitas das instituições de Roma. A grande novidade é o cristianismo, que a partir de seu governo passa a ser institucionalizado e configura uma forma arquitetônica específica para o seu culto: as igrejas. Remetendo-nos às idéias de Duncan (1990), o que vemos aqui é um momento de mudança nas relações de poder que vai se expressar na configuração de um novo edifício - a igreja cristã - que vai demandar um novo comportamento daqueles que fazem uso dele.

Já mencionamos no início desta dissertação que vemos a arquitetura como uma forma de linguagem que estabelece uma comunicação não-verbal com os indivíduos que fazem uso de suas formas. Assim, entendemos que o uso da forma de basílica nas igrejas cristãs, mais do que uma estrutura adequada, passa uma mensagem: de que aquele edifício faz parte do Império Romano e nele está materializado o poder do seu imperador. Para os indivíduos que viveram esse momento de mudança, a mensagem era clara, uma vez que eles tinham conhecimento da instituição romana que deu origem à basílica cristã. A apreensão desse código era possível para todos aqueles que viveram nos limites do Império Romano, inclusive nas colônias que, como já vimos, tinham instituições e edifícios romanos que faziam parte da vida de suas cidades.
Os exemplos do Templo da Concórdia de Agrigento e do Athenaion de Siracusa foram apresentados nesse trabalho para mostrar que, ao voltarmos ainda mais no tempo, até o período Clássico (séculos VI e V a.C.) na Grécia e em suas colônias, quando o templo grego se estabelece como edifício para a reunião com a finalidade de realização do culto religioso, pudemos observar que a forma da basílica já está delineada ali. $\mathrm{O}$ recuo na linha do tempo até cerca de um milênio antes do recorte temporal estipulado nessa dissertação tem a finalidade de nos mostrar que, apesar das condições socio-econômicas, políticas e culturais mudarem no decorrer dos anos e séculos, os edifícios não se transformaram completamente; foi por meio dessa regressão que nos foi possível identificar os elementos arquitetônicos que permaneceram desde a antiguidade, identificados em época grega, passando pelo período romano, chegando até o período bizantino, que estudamos mais a fundo nessa dissertação, e que se mantiveram por mais alguns séculos, atravessando a Idade Média, o Renascimento e a Idade Moderna para ainda na atualidade continuarem a ser usados. Esse é um tempo histórico que a escola dos Annales chamou de "La longue durée" - a longa duração - que como apresentamos na introdução deste trabalho, abrange os processos históricos que duram séculos e que são possíveis de serem identificados pela pesquisa arqueológica.

Desde a proposta inicial, nos dispusemos a realizar neste trabalho uma investigação a respeito da permanência de formas clássicas nas igrejas paleocristãs, o que nos permitiu ver, a partir de um exemplo concreto, que os edifícios não se transformam completamente, mas são readaptados para adequar-se ao novo caráter das atividades que vão ser realizadas no seu espaço. A partir de nossas pesquisas fomos capazes de identificar alguns elementos arquitetônicos que se mantiveram em uso através dos séculos, passando por várias sociedades, tais como a forma de basílica e o uso das colunas e capitéis. Vimos também que para abrigar o culto cristão, a basílica sofre algumas modificações. No catálogo temos vários exemplos de igrejas onde à forma elementar da basílica são anexadas outras estruturas, tais como capelas, batistérios e salas auxiliares ao culto, como o diaconicon, mas mesmo com todos esses acréscimos a estrutura da basílica não é alterada. Também os capitéis 
coríntios, quando usados nas colunas das igrejas protocristãs, em muitos casos são acrescidos de uma cruz, como na igreja da Natividade.

Uma vez identificadas e ressaltadas as mudanças que as basílicas cristãs apresentam em relação às formas das quais elas se originam, cabe a nós agora nos concentrarmos na questão da permanência das formas, explorando os motivos da sua ocorrência em cada período: na Grécia Clássica, no Império Romano e no período bizantino, a fim de encontrar algum ponto de contato que possa explicar a sua permanência ao longo de todo esse espaço de tempo. Retomemos então a forma mais antiga: o templo grego. Já mencionamos nesse capítulo que entre o templo grego e a igreja cristã existe a permanência do uso como edifício de culto religioso, e os exemplos dos templos em Siracusa e Agrigento nos mostram que, para que sua utilidade para a religião pudesse permanecer foram necessárias algumas poucas mudanças formais. Na Grécia da antiguidade, o templo é o edifício que recebe em primeiro lugar a monumentalização. No mundo das póleis gregas ele é o lugar de maior poder e maior integração da comunidade; é nos santuários pan-helênicos que as cidades (póleis) do mundo grego se reúnem, pois a religião é, nesse universo, um ponto de contato e integração entre as diferentes comunidades. Em muitas dessas pólis, o templo é o edifício que se destaca na paisagem, e devido ao seu caráter monumental, é a forma arquitetônica onde se manifesta o poder da pólis, tanto internamente, para os seus cidadãos, quanto externamente, frente às outras póleis. Vale ainda retomar a questão do culto, que na religião grega é realizado do lado de fora do templo, no altar, onde todos os indivíduos da pólis têm acesso ao ritual.

Já no Império Romano, identificamos a forma de basílica que permanece nas igrejas paleocristãs em um edifício civil, também chamado de basílica. Além do relato de Vitrúvio (1999:121-122), pesquisamos a respeito da configuração espacial e do uso da basílica romana em diversos autores, tais como Barton (1995), Ward-Perkins (1981), Wheeler (1995) e Zanker, onde encontramos o relato de que a basílica em época romana tinha vários usos, como já delineamos anteriormente neste trabalho. Retomemos então as características da basílica romana a partir do relato de Zanker: "a basílica multifuncional era a concretização perfeita das necessidades ideológicas e práticas da sociedade romana. Ela podia ser facilmente subdividida em diferentes compartimentos e, pelo uso de uma exedra ou de um tribunal, podia também ser articulada de forma hierárquica. $\mathrm{O}$ importante papel da basílica normalmente se reflete pela sua posição na praça pública. Muitas vezes ela forma um contraponto com o templo tanto no tamanho quanto na paisagem. $\mathrm{Na}$ época do principado, o fórum não funcionava tanto como um espaço de reuniões para a sociedade romana, mas era um lugar onde ocorriam as cerimônias religiosas e políticas e os rituais, e onde os negócios e os assuntos legais eram tratados. Os últimos eram realizados especificamente na basílica, onde então se concretizava a identidade política e jurídica da cidade. Visto por um outro lado, a necessidade de uma basílica era a expressão do caráter romano de uma cidade. Posteriormente, o embelezamento das basílicas com estátuas e altares contribuiu significativamente para a veneração da família imperial. A basílica envolvia uma parte correspondente ao Capitólio ou ao templo, dedicada ao culto do imperador no centro monumental da cidade. Essa duplicidade projeta uma mensagem importante. Os dois pólos da autonomia urbana e da absoluta fidelidade e subserviência a Roma e aos seus deuses encontrou uma expressão visual acessível na evidente justaposição do Capitólio e do edifício cívico multifuncional. Quando este último passou a abrigar um tribunal ou uma exedra com estátuas dos membros da família imperial, estabelecendo um eixo direto que se estende pelo fórum até o templo, o quadro ideológico havia se tornado claro para todos" (Zanker 2000:36-37) Essa descrição de basílica feita por Zanker merece ser destacada na medida em que o autor vai além dos aspectos formais, fornecendo-nos também uma interpretação ideológica sobre o edifício, onde a relação com o templo e a presença do poder imperial são evidenciadas. Carter (1995:43) também nos chama a atenção para essas relações ao afirmar que "durante a transformação do Estado que tem início com César e foi completada, ao menos em seus aspectos essenciais, na época da morte de Augusto, a arquitetura passou, ao menos no que diz respeito aos grandes edifícios públicos, de um método de autopropaganda para uma expressão e instrumento do poder político." Esses autores trazem a nós informações que permitem 
entender a basílica de uma maneira mais profunda, percebendo que ela era mais do que um mero edifício que tem como função abrigar um grande número de pessoas, mas acomoda também em seu espaço os tribunais, escritórios administrativos e, posteriormente, estátuas de membros da família imperial. Ela é a materialização do culto imperial e mais ainda, das relações de poder que se estabelecem no seu ambiente.

A basílica cristã, como já relatamos, toma forma durante o período bizantino, e tem como finalidade abrigar o ritual cristão com todas as suas especificidades. A assembléia cristã se reúne no espaço da igreja para que a celebração do ritual se realize. A integração da comunidade se faz por meio do sacerdote, que intermedia o contato dos cristãos com o seu Deus. Uma vez que, como já vimos, a partir de Constantino a igreja é institucionalizada e, tendo o imperador se intitulado o representante na terra de um soberano que está no céu, as questões políticas e religiosas passam a estar relacionadas, e a forma desse espaço também faz parte dessa mensagem. "A adoção da forma de basílica como espaço de veneração ao Deus cristão foi trazida não apenas por considerações práticas, mas também pela sua associação simbólica com o amplo espaço que reverencia o imperador" (Carter 1995:58). Com essa afirmação vemos que esse autor compreende as basílicas cristãs da mesma maneira que interpreta as basílicas romanas: como uma expressão e instrumento do poder político, materializado pela figura do imperador.

Anteriormente, nesse mesmo capítulo, falamos sobre o termo "basílica" e indicamos as palavras gregas "basileu" e "basiléia" - rei e realeza - como suas origens. Agora que nos aprofundamos na investigação das atividades que se realizam nos espaços das basílicas romana e cristã e vimos que a permanência da forma está relacionada à ligação que ela estabelece com o imperador, tanto no Império Romano quanto no período bizantino, somos capazes de compreender que o uso da palavra "basílica" para designar esses edifícios já evidencia, pelas suas origens, a relação que essas formas arquitetônicas estabelecem com o poder real.

Após essa extensa análise, gostaríamos de ressaltar alguns pontos que dizem respeito à permanência de formas arquitetônicas grecoromanas nas igrejas paleocristãs. Em primeiro lugar, o uso das formas do templo grego e da basílica romana pela igreja cristã são duas situações que não têm correspondência uma com a outra. Nossas pesquisas não revelaram em momento algum que houve a transformação do templo grego em basílica romana e, a partir daí em edifício cristão e por esse motivo as duas situações, a da mudança de templo grego para igreja e a permanência da forma de basílica romana nas igrejas cristãs foram tratadas de forma independente.

Por outro lado, para além de sua forma, esses três edifícios: o templo grego, a basílica romana e a igreja cristã apresentam algumas similaridades. Em todos os edifícios pudemos identificar uma hierarquização dos espaços, que são divididos e que permitem o acesso restrito a apenas alguns indivíduos que o utilizam. No caso do templo grego, existe a cela, onde está a estátua de culto; na basílica romana, temos as absides, onde ficam os magistrados ou as exedras, que abrigam as estátuas de membros da família imperial; e nas igrejas cristãs há o bema, a parte que contém o altar e onde o clero fica durante as celebrações; nas igrejas existe também o nártex, corredor de transição entre o átrio - espaço exterior e as naves - o interior, onde aqueles indivíduos que não eram batizados podiam assistir ao ritual. Inspirados em Duncan (1990), entendemos a existência de espaços hierarquizados nesses edifícios como uma materialização na arquitetura de uma vontade por parte dos grupos dominantes de controlar e disciplinar os indivíduos que fazem uso desse espaço.

Existe ainda um outro aspecto essencial, comum a essas três construções. Nos templos gregos, que manifestam o poder da pólis em sua monumentalidade, nas basílicas romanas, pela presença do culto imperial e de mecanismos de execução das leis por meio dos tribunais, nas igrejas paleocristãs, que tem na figura do imperador a materialização do poder divino, em todos esses edifícios podemos interpretar a arquitetura como a materialização de um poder, poder esse que articula e integra a comunidade. Desse modo, o que garante a permanência dessas formas arquitetônicas é a sua associação aos tipos de poder, a quem por sua vez interessa a manutenção da forma espacial, pois a mensagem visual que ela transmite já foi, com o passar dos séculos, incorporada a esse poder. 


\section{5 - Conclusão}

$A$ idéia inicial a partir da qual esse trabalho se configurou foi a busca das formas arquitetônicas clássicas que permaneceram nas igrejas paleocristãs. Nossa amostragem se restringiu às igrejas que foram construídas entre a primeira metade do século IV e o final do século VI d.C. na região da Palestina. A partir de sua identificação, procuramos explorar a maneira como essas formas foram usadas: se permaneceram no período bizantino como eram na antiguidade ou se sofreram alterações e em que medida elas foram modificadas. Buscamos ir além da análise estritamente formal, vendo essas igrejas também como a materialização de um momento de mudança e entendendo essa estrutura arquitetônica como um elemento constitutivo de uma sociedade em transformação, no período intermediário entre a antiguidade e a Idade Média.

Para que conseguíssemos ultrapassar o limite da interpretação puramente formal da arquitetura tivemos que compreendê-la como uma forma de comunicação não-verbal, uma manifestação que traz uma linguagem própria e que é capaz de nos fornecer por meio dessa linguagem dados a respeito do momento histórico que fez uso de seu espaço. Foi a partir dessa perspectiva que procuramos observar as igrejas paleocristãs: como objetos materiais que, com uma linguagem particular, eram capazes de trazer em suas formas um relato a respeito do contexto onde elas foram criadas e usadas e da situação social, políticoeconômica e cultural da qual elas fazem parte.

A opção de elaborar um catálogo que organizasse todas as informações obtidas com a pesquisa das igrejas foi adotada a fim de que os dados fossem apresentados de forma sistemática, possibilitando-nos organizar essas informações em gráficos e tabelas, que se mostraram bastante úteis no momento em que realizamos uma análise interpretativa dessas igrejas, apresentada no capítulo 4 dessa dissertação.

Os dados obtidos a partir do catálogo de igrejas protocristãs nos mostraram dois ele- mentos nos quais a questão da permanência das formas arquitetônicas foi atestada: no uso dos capitéis, principalmente da ordem coríntia e na adoção da forma de basílica como edifício de culto cristão. No caso dos capitéis coríntios, remontamos ao período do seu surgimento na Grécia do século $\mathrm{V}$ a.C. e pudemos observar a continuidade e difusão da sua utilização nos edifícios de época romana até chegar à sua utilização nas igrejas cristãs. No caso da basílica encontramos no passado duas situações de uso dessa forma que atestam a sua permanência no período bizantino, mas que são independentes, no sentido de que não se conformam com uma transformação em duas etapas ao longo do tempo. Uma dessas situações é o reaproveitamento da estrutura do templo grego para sua utilização como igreja cristã, como nos mostram os casos do Athenaion de Siracusa, transformado em igreja no século VII d. C. e o Templo da Concórdia em Agrigento, cuja modificação para o uso como basílica data do século VI d.C. A outra situação foi a utilização da forma da basílica romana nas igrejas cristãs. Nesse caso, procuramos nos aprofundar na maneira como a basílica era usada pelos romanos como edifício cívico em contraposição ao uso religioso que ela passa a adotar em época bizantina.

Interpretamos as mudanças empreendidas para a adequação dos templos gregos para o culto cristão e o uso da basílica como edifício de culto religioso, a mesma forma que anteriormente era utilizada como edifício cívico em época romana, como manifestações concretas de uma nova situação que se configura, de uma mudança nos costumes e nas mentalidades, que reaproveita formas antigas para novos usos e introduz elementos novos à vida cotidiana. A ocorrência da forma de basílica com um novo uso a partir do século IV d.C. expressa as relações de poder que se estabelecem nessa época, quando, a partir do governo de Constantino a igreja cristã passa a fazer parte do Estado, ao mesmo tempo que o imperador se torna o representante de Deus na 
terra. As igrejas cristãs são a materialização de uma nova mentalidade que se estrutura no período bizantino, marcadas pela relação intrínseca entre religião e política.

A forma de basílica, entendida como uma estrutura que se mantém através dos séculos, na longa duração, tem como fio condutor da sua permanência a questão do poder, que pode ser identificado como elemento articulador dessa forma nas três situações temporais que exploramos nessa dissertação, a saber: a Grécia Clássica, o Império Romano e o período bizantino

Ao nos aprofundarmos no estudo das igrejas cristãs para além de sua estrutura formal, o que nos saltou aos olhos foi a nova configuração sob a qual o poder imperial de Roma se manifestou a partir de Constantino e que se apresenta nas igrejas mais do que em qualquer outro edifício público que existiu nessa época. Foi muito interessante pesquisar e constatar de que maneira uma forma arquitetônica, que no nosso caso foi a forma de basílica, foi reaproveitada e reinterpretada com um novo uso por uma sociedade em transformação. $\mathrm{O}$ aprofundamento no estudo de um elemento material se mostrou essencial no entendimento de como esse momento de mudança se configurava no período abordado. As igrejas, com sua linguagem não-verbal, evidenciaram em sua configuração espacial a estreita relação entre religião e Estado e a nova estrutura de poder que foi estabelecida a partir do século IV d.C. com Constantino. Além disso, pela sua nova estética, que usou os elementos clássicos não mais no exterior e sim no interior dos edifícios, que se despoja da monumentalidade exterior dos templos para evidenciar a dramaticidade do jogo de luz e sombra, claro e escuro, no interior dos edifícios, as igrejas cristãs manifestam em suas formas as transformações sociais e culturais que configuram o período bizantino. Sendo um momento de passagem de uma situação estabelecida na história, que entendemos como a antiguidade para um modo de vida e uma visão de mundo muito diferentes, aos quais chamamos de Idade Média, o período bizantino é um momento de transformação, de manutenção de certos elementos, mas de criação de outros novos. Foi esse momento de mudança, sempre complexo, que pudemos identificar e compreender melhor com o estudo da permanência de formas clássicas nas igrejas paleocristãs. 


\section{GLOSSÁRIO}

$$
D_{\text {sa, nos deparamos com termos }}^{\text {urante a elaborãao dessa pesqui- }}
$$
que trazem um significado bastante específico, o que nos levou a elaborar um glossário, usado como ferramenta auxiliar em nossas leituras, para uma rápida compreensão de palavras que não fazem parte do nosso cotidiano. Optamos por apresentar este glossário aqui também como uma ferramenta para nossos leitores, no qual não nos limitamos a apresentar apenas os termos presentes no texto final deste trabalho, mas também palavras de significado importante e pertinentes ao tema estudado, que estão presentes na bibliografia consultada para esse estudo. Os termos apresentados neste glossário se referem em grande medida a elementos arquitetônicos característicos do nosso objeto de estudo - as igrejas cristãs - mas também estão presentes termos bastante utilizados nos textos que tratam da arquitetura e do urbanismo de época clássica.

Aedicula - altar em miniatura, normalmente na forma de templo ou um nicho adornado por colunas.

$A m b o$ - o púlpito elevado no ambiente principal (nave) da igreja.

Abside - Palavra que tem origem no termo grego apsís. No templo grego é nessa parte, no Leste, onde fica a estátua de culto, a entrada e do lado de fora do templo, o altar. É uma construção abobadada de planta semicircular ou poligonal. Nas basílicas romanas era na abside que ficava o pretor e outras personalidades, como os magistrados, durante as sessões públicas e julgamentos. Posteriormente ela foi incorporada à planta das igrejas cristãs, situada na parte posterior e usada como local de assento do clero, coro ou altar-mor, significando, simbolicamente, o paraíso. Comumente em uma igreja cristã a abside está localizada no lado do sol nascente, a Leste. Usualmente ela é decorada por mosaicos ou pinturas murais. Na sua frente situa-se o bema.
Absidal - Espaço edificado que tem a forma de abside.

Átrio - o pátio anterior à igreja, normalmente localizado na extremidade Oeste do edifício e na maioria dos casos rodeado por um pórtico. A forma latina do nome - atrium - designa o jardim interno da casa romana, mas ao que parece a origem do uso em época bizantina é derivado da palavra em grego "aitrion" significando "um lugar aberto para o ar e o vento"

Basílica - forma latina do grego "basileu" ( $\beta \alpha \sigma \iota \lambda \varepsilon \cup s)$, que significa "rei" "real" (estrutura); em grego "basiléia" (basileia) significa "realeza" - Esse é o termo comum para os edifícios cívicos romanos ou para salas dentro dos complexos palaciais. No período cristão "basílica" foi sinônimo para "igreja" $\mathrm{Na}$ classificação de igrejas, "basílica" indica uma estrutura longilínea em forma de corredor, dividida em nave central e naves laterais por fileiras de colunas, onde na extremidade Leste localizam-se o bema e a abside.

Batistério - sala em uma igreja ou em um edifício próximo que contém a pia bastimal.

Bema - significa "lugar alto" em hebraico; em grego $(\beta \eta \mu \alpha)$ significa passo, degrau, plataforma elevada; em uma igreja, é a parte dedicada ao clero, sinônimo de coro; a parte da igreja que contém o altar; o lugar dos padres; ver presbyterium.

Cancellus - o biombo do coro, o parapeito baixo que cerca o bema. Era usualmente feito de pedra ou com colunas e painéis de mármore.

Capela - Pequena igreja de um só altar, ou sala anexa a uma igreja com altar próprio.

Cardo - a rua transversal na cidade romanobizantina, que cruza o Decumanus em ângulo reto.

Catecúmenos - candidatos à conversão para o Cristianismo, que recebem ensinamentos sobre os princípios básicos da religião, mas ainda não foram batizados. 
Catedral - do latim cathedra: cadeira, trono episcopal. Igreja principal de uma diocese e o mais importante local de culto da sede episcopal.

Cela - sinônimo de nave (vaos), termo grego que designa a sala principal do templo, que contém a estátua do deus.

Ciborium - o dossel destacado sobre o altar, suportado por quatro colunas, independentes do restante da estrutura da igreja.

Cripta - a sala ou túmulo abaixo do piso da igreja, usada para sepultamentos ou para guardar relíquias.

Curiales - o conselho governante nas cidades que foram ocupadas pelo Império Romano durante a sua existência.

Decumanus - a rua transversal da cidade romano-bizantina, que cruza o Cardo em ângulo reto.

Diaconicon - a sala usada pelos padres e seus assistentes (diáconos) para armazenar oferendas trazidas até a igreja, suas vestes e artefatos de culto. Inicialmente se unia ao hall da igreja ou ao átrio, mas posteriormente tornou-se a sacristia da igreja, localizada ao sul da abside central.

Domus ecclesia - termo em latim para "casa da igreja"; era um termo comum para denominar as igrejas pré-Constantino da congregação cristã, construídas como casas privadas; em grego, a palavra "ekklesía" ( $\varepsilon \kappa \kappa \lambda \varepsilon \sigma \iota \alpha)$ significa uma reunião dirigente, uma assembléia que materialmene reúne as pessoas para decisões políticas. No mundo grego, é o templo que reúne as pessoas para os ritos religiosos.

Estilóbato - base contínua que suporta uma fileira de colunas.

Eucaristia - termo em grego para "agradecimento pelas oferendas"; o sacramento no qual o pão e o vinho são partilhados para rememorar a morte de Cristo.

Exonártex - o pórtico externo da igreja, entre o nártex e o átrio.

Igreja - tem origem no termo grego "ekklesía" $(\varepsilon \kappa \kappa \lambda \varepsilon \sigma \iota \alpha)$ : assembléia. Designa o edifício onde se realiza o culto cristão; ver domus ecclesia.

Insula - termo em latim para "ilha"; bairro residencial nos estabelecimentos romano-bizantinos, circundado por ruas.
Liturgia - o termo grego para missa; o rito ou corpo de ritos na igreja, incluindo a eucaristia. É sinônimo de "missa" em latim.

Mártir - termo grego para "testemunha"; designa uma pessoa que foi perseguida até a morte pela sua fé e que a partir disso se tornou um santo.

Martyrium - uma igreja, ou parte de uma igreja, onde os restos de um santo foram sepultados. $\mathrm{Na}$ literatura especializada o termo veio a designar o tipo de estrutura concêntrica (redonda), poligonal ou cruciforme própria de uma igreja comemorativa.

Memorium - um monumento ou uma igreja comemorativa.

Nártex - termo grego para "recipiente"; amplo corredor ou pórtico localizado na extremidade Oeste da nave da igreja, entre a igreja e o átrio. Durante a eucaristia os catecúmenos permaneciam nesse lugar.

Nave - tem origem no termo grego "naos" (voos), que designa a sala principal no templo grego, onde fica a estátua de culto. Esse sentido também permaneceu nas igrejas, onde a nave corresponde à sua sala principal, que abriga a comunidade no culto cristão. Nas igrejas que têm a forma de basílica a nave está dividida em nave central, que é a porção central do ambiente, separada das naves laterais, que são os lados da nave da igreja, por duas fileiras de colunas.

Onomasticon - termo grego para "lista de nomes"; um volume escrito em Grego, identificando os lugares da Palestina mencionados nas Escrituras. Foi compilado por Eusébio, bispo de Cesarea, por volta do ano 300 d.C.

Opaion/oculus - palavras grega e latina, respectivamente, para "olho"; abertura circular no ápice do domo de uma igreja.

Opistódomo - o pórtico localizado atrás da cela nos templos gregos, que muitas vezes serve como entrada dos fundos.

Opus sectile - pavimento ou revestimento de placas de mármore colorido assentadas de várias maneiras.

Opus vermiculatum - mosaico feito com tesserae pequenas, alongadas e de forma irregular. Ovolo - um padrão de "ovo e seta" nas molduras arquitetônicas. 
Paramonarios - o sacristão, guardião das vasilhas de culto e dos objetos valiosos pertencentes à igreja ou monastério.

Parvis - pátio; a praça de entrada da Igreja do Santo Sepulcro em Jerusalém.

Pastophorium - termo em latim para "altar"; salas em qualquer um dos lados da abside central.

Plinto - a base quadrada mais baixa da base de uma coluna.

Polycandelon - candelabro.

Pórtico - colunada aberta que sustenta um teIhado.

Presbyterium - termo grego para "lugar dos anciãos"; termo comum para o bema, ou a entrada que era restrita aos padres.

Pronaos - no templo grego, é o pórtico, o ambiente que se atravessa para a acessar a nave ("naos").

Prothesis - termo grego para "apresentação em público" - na religião católica é o processo pelo qual o pão sagrado foi feito e apresentado antes da liturgia, e em certas épocas refere-se à sala ou recesso ao norte da abside central da igreja no qual o pão santo foi preparado. Ver diaconicon.
Relicário - recipiente no qual relíquias sagradas, normalmente ossos de santos, eram guardadas; em alguns casos tinham a forma de um sarcófago em miniatura.

Souk - o mercado árabe.

Synthronon - termo grego para "trono mútuo"; banco, de frente para o público, onde os padres e o bispo se sentavam; usualmente era construído na forma de degraus atrás do altar, no recuo semicircular da abside.

Tabula ansata - moldura retangular, com uma orelha de forma triangular em cada um dos seus lados menores, dentro da qual há uma inscrição; é normalmente encontrada em pisos de pedra ou de mosaico.

Temenos - precinto; o terreno sagrado de um templo.

Tessera - termo grego para "algo que tem quatro cantos" - pequeno pedaço de pedra, vidro ou cerâmica, utilizado nos trabalhos em mosaico.

Transepto - a sala transversal em uma igreja, que cruza em ângulo reto o maior comprimento entre a nave e a abside, assim formando uma configuração cruciforme. 



\section{BIBLIOGRAFIA *}

$\begin{array}{ll}\text { Abreviações } \\ \text { AMBSR } & \begin{array}{l}\text { Archaeological Monographs of the } \\ \text { British School at Rome }\end{array} \\ \text { EMC } & \text { Echos du Monde Classique } \\ \text { BAR } & \text { British Archaeological Reports } \\ \text { IEJ } & \text { Israel Exploration Journal } \\ \text { JAR } & \text { Journal of Archaeological Research } \\ \text { JECS } & \text { Journal of Early Christian Studies } \\ \text { JRA } & \text { Journal of Roman Archaeology }\end{array}$

\section{Fontes}

\section{Fontes escritas}

EUSÉBIO DE CESAREA. Vida de Constantino. Madrid, Editorial Gredos, 1994.

História Eclesiástica. Madrid, Biblioteca de Autores Cristianos, 2001.

VITRÚVIO, Da Arquitetura. Tradução de Marco Aurélio Lagonegro, São Paulo, Editora Hucitec - FUPAM, 1999.

\section{Fontes arqueológicas}

STERN, E. (ed.) The New Encyclopedia of Archaeological Excavations in the Holy Land. Jerusalem, The Israel Exploration Society, 1993.

TSAFRIR, Y. (ed.) Ancient Churches Revealed. Jerusalem, Israel Exploration Society, 1993.

\section{Referências bibliográficas}

AA.VV. L'Italia dei Greci - Archeoguide. Milano, Agostini Rizzioli Periodici S. r. 1., n. 1, 2005.

AA.VV. Highlights of Recent Excavations. Jerusalem, Israel Antiquities Authority, 1990.
AA.VV. "The Roman and Byzantine Near East: some recent archaeological research" JRA, Supl. 14, Michigan, Ann Arbor, 1997.

ALBERNAZ, M.-P. e LIMA, C. M. Dicionário Ilustrado de Arquitetura. 3. ed. São Paulo, ProEditores Associados Ltda., 2003.

ALBRIGHT, W. F. The Archaeology of Palestine. Gloucester, Peter Smith,1971.

ALCOCK, S. (ed.). The Early Roman Empire in the East. Oxford, England, Oxbow Books, 1997.

ANDERSON Jr., J. C. Roman Architecture and Society. Baltimore, The Johns Hopkins University Press, 1997.

ANDRÉN, A. Beetween Artifacts and Texts: Historical Archaeology in Global Perspective. New York, Plenum, 1998.

APPLEBAUM, S. L'Archeologie en Israel. Jerusalém, Semaine Israelienne, 1959.

"The Settlement Pattern of Western Samaria from Hellenistic to Byzantine Times: A Historical Commentary" BAR 308, 1986, pp. 256-269.

ARNHEIM, R. Arte e Percepção Visual: uma Psicologia da Visão Criadora. 6. ed. São Paulo, Livraria Editora Pioneira, 1991.

AUSTIN, D. and L. ALCOCK (eds.) From the Baltic to the Black Sea, Studies in Medieval Archaeology. London, Unwin Hyman, 1990.

BAHN, P. The Cambridge Illustrated History of Archaeolgy. Cambridge, Cambridge University Press, 1996.

BARKER, G. e LLOYD, J. "Roman Landscapes. Archaeological Survey in the Mediterranean Region". AMBSR, 2, 1991. 
BARRAL e ALTET, X. A Alta Idade Média da Antigüidade Tardia ao ano Mil. Colônia, Taschen, 2002.

BARTON, I. (ed.). Roman Public Buildings. Exeter, University of Exeter Press, 1995.

BAXANDALL, M. Patterns of Intention. On the Historical Explanation of Pictures. London, Yale University Press, 1985.

BEARD, M., NORTH, J. e PRICE, S. Religions of Rome - volume I: a History. Cambridge, Cambridge University Press, 1998.

BIERS, W. R. The Archaeology of Greece - an introduction. 5. ed. Ithaca, London, Cornell University Press, 1986.

BOARDMAN, J. The Oxford History of Classical World. Oxford, Oxford University Press, 1988.

Greek Sculpture: The Late Classical Period and Sculpture in Colonies and Overseas (World of Art). New York, Thames and Hudson, 1991.

. (ed.). The Cambridge Ancient History Vol IV. Persia, Greece and the Western Mediterranean. New York, Cambridge University Press, 1992.

(ed.). The Diffusion of Classical Art in Antiquity. London, Thames and Hudson, 1994.

The Oxford History of Greece and the Hellenistic world. Oxford (England), New York, Oxford University Press, 2001.

(ed.). The Oxford History of Classical Art. Oxford (England), New York, Oxford University Press, 2001.

BOWDER, D. Who was who in the Roman World: $753 B C-A D$ 476. Oxford, Phaidon, 1980.

BOWERSOCK, G. W. Hellenism in Late Antiquity. Michigan, The University of Michigan Press, 1996.

BRADFORD, J. Ancient Landscapes. London, G. Bell and Sons, 1957.

BRÉHIER, L. Vie et mort de Byzance. Paris, Éditions Albin Michel, 1946.
BROWN, P. O Fim do Mundo Clássico: de Marco Aurélio a Maomé. Lisboa, Verbo, 1972.

Society and the holy in late antiquity.

London, Faber and Faber, 1982.

De l'Empire Romain à l'an mil. Série: Histoire de la Vie Privé, vol. 1. Paris, Seuil, 1985.

. The world of Late Antiquity: ad

150-750. London, Thames and Hudson, 1995.

The making of late antiquity. Cambridge, Harvard University Press, 1996.

Authority and the sacred: aspects of the Christianisation of the Roman world. Cambridge (England); New York, Cambridge University Press, 1997.

Late antiquity. Cambridge, Belknap Press of Harvard University Press, 1998.

BUNSON, M. A Dictionary of the Roman Empire. Oxford, Oxford University Press, 1991.

BURCKHARDT, J. The Age of Constantine the Great. Berkeley, University of California Press, 1983.

BUSHELL, G. Churches of the Holy Land. London, Cassell and Company Ltd., 1969.

CADIZ, L. M. Historia de la Literatura Patrística. Buenos Aires, Editorial Nova, [1954].

CAMERON, A. e GARNSEY, P. (ed.) The Cambridge Ancient History - volume XIII The Late Empire, A. D. 337-425. Cambridge, Cambridge University Press, 1998.

CARCOPINO, J. Études d'Histoire Chrétienne. Paris, Éditions Albin Michel, 1953.

CARTER, J. "Civic and other buildings" in BARTON, I. (ed.). Roman Public Buildings. Exeter, University of Exeter Press, 1995, cap. 2, pp. 31-65.

CERCHIAI, L., JANELLI, L. e LONGO, F. The Greek Cities of Magna Graecia and Sicily. Los Angeles, The J. Paul Getty Museum, 2004.

CHARBONNEAUX, J., MARTIN, R. e VILLARD, F. Grèce Hellénistique (330-50 avant J.-C.). Collection "L'Univers des Formes" France, Éditions Gallimard, 1970. 
CHILDE, G. A revolução Urbana. São Paulo, FAU, 1971.

O que aconteceu na História? Rio de Janeiro, Zahar, 1977.

CLARKE, D. L. (ed.) Spatial Archaeology. London, 1977.

COARELLI, F. e TORELLI, M. Guide Archeologiche Laterza: Sicília. 2. ed., Bari, Gius. Laterza \& Figli, 1988.

COLLON, D. Ancient Near Eastern Art. London, British Museum Press for the Trustees of the British Museum, 1995.

CORONA, E. e LEMOS, C. A. C. Dicionário da Arquitetura Brasileira. 2. ed. São Paulo, Art Show Books Ltda., 1989.

COTTERELL, A. (ed.). The encyclopedia of ancient civilizations. London, Penguin Books, 1988.

CROWE, N. Nature and the idea of a man-made world: an investigation into the evolutionary roots of form and order in the built environment. Cambridge, The MIT Press, 1995.

CROWFOOT, J. W. Early Churches in Palestine. London, 1941.

DE CERTEAU, M. A invenção do Cotidiano. Petrópolis, Vozes, 2002.

DIEHL, C. Byzance: grandeur et decandence. Paris, Flammarion, 1949.

Os Grandes Problemas da História Bizantina. São Paulo, Editora das Américas, 1961.

DUNCAN, J. S. The City as a Text - the Politcs of Landscape Interpretation in the Kandyan Kingdom. Cambridge, Cambridge University Press, 1990.

ECO, U. A Estrutura Ausente. São Paulo, Perspectiva, 1974.

ELIADE, M. História das crenças e das idéias religiosas. Rio de Janeiro, Zahar Editores, 1978.

Tratado de história das religiões. São

Paulo, Martins Fontes, 1993.
FOSS, P. W. "The Social City" JRA, 9, 1996, pp. 351-352.

FLETCHER, R. "The messages of material behaviour: a preliminary discussion of non-verbal meaning" in HODDER, I. (ed.) The Meaning of the Things. London, Harper Collings, 1991.

FORNARA, C. W. The nature of history in ancient Greece and Rome. Berkeley, University of California Press, 1983.

FORSTER, K. W. "Introdução" in WARBURG, A. The Renewal of Pagan Antiquity: Contributions to the Cultural History of the European Renaissance. Los Angeles, The Getty Research Institute for the History of Art and the Humanities, 1999, pp. 1 a 75.

FRANCO JR., H. e ANDRADE Fo., R. O. $O$ Império Bizantino. Coleção Tudo é História $\mathrm{n}^{\circ}$ 107, 3. ed., São Paulo, Brasiliense, 1989.

FREPPEL, Mg. Les Origines du Christianisme. Paris, Victor Retaux Librarie-éditeur, 1903.

GALVÃO SOBRINHO, C. R. e FLORENZANO, M. B. B. "Apolônia e seu território: paisagem rural e mudança social na Palestina romana". Revista do MAE, 12, 2002.

GEERTZ, C. A interpretação das culturas. Rio de Janeiro, Guanabara, 1989.

GINOUVÈS, R. L'Art Grec. Paris, Presses Universitaires de France, 1964.

GINZBURG, C. Mitos, Emblemas, Sinais: morfologia e história. 2. ed. São Paulo, Cia. Das Letras, 2003.

GOMBRICH, E. H. Arte e Ilusão: um estudo da psicologia da representação pictórica. 3. ed. São Paulo, Martins Fontes, 1995.

GRABAR, A. "Christian Architecture, East and West”, in Archaeology 2, 1949, pp. 95-104.

GRIFFO, P. Akragas - Agrigento: la storia, la topografia, I monumenti, gli scavi. Agrigento, Legambiente, 2005.

HAMMOND, N. G. L. and SCULLARD, H. H. (eds.) The Oxford Classical Dictionary. Oxford (England), Clarendon Press, 1991. 
HAUSER, A. História Social da Literatura e da Arte. São Paulo, Mestre Jou, 1982.

HILLIER, B. e HANSON, J. The Social Logic of Space. Cambridge, Cambridge University Press, 1984

HODDER, I. (ed.) The Meaning of the Things. London, Harper Collings, 1991.

HORDEN, P. \& PURCELL, N. The Corrupting Sea: A study of Mediterranean History. Oxford, Blackwell, 2000.

HORSLEY, R. A. Bandidos, profetas e messias: movimentos populares no tempo de Jesus. São Paulo, Paulus, 1995.

HORSLEY, G. H. R. New documents illustrating early christianity. Macquaries, Macquarie University, 1989.

ISRAELI, Y. e MEVORAH, D. (ed.). Cradle of Christianity. Jerusalem, The Israel Museum, 2000.

JACOBY, R. e TALGAM, R. Architectural Glossary. Jerusalem, Israel Exploration Society, 1990.

JAMES, L. Color and Meaning in Byzantium. Journal of Early Christian Studies, vol. 11, $\mathrm{n}^{\circ} 2$, Johns Hopkins University Press, 2003.

JANSON, H. W. História da Arte. 5. ed. São Paulo, Martins Fontes, 1992.

JONES, A. H. M. The Greek City from Alexander to Justinian. Oxford, The Clarendon Press, 1940.

Constantine and the Conversion of Europe. Toronto, University of Toronto, 1978.

The Later Roman Empire 284-602. vols. I e II, Baltimore, The Johns Hopkins University Press, 1986.

KASHER, A., RAPOPORT, U. e FUCKS, G (eds.). Greece and Rome in Eretz Israel. Jerusalem, Yad Izhak Ben-Zvi and The Israel Exploration Society, 1990.

KRAUTHEIMER, R. Early Christian and Byzantine Architecture. Penguin, Harmondsworth, 1965.

KOLB, F. La ciudad en la Antigüedad. Madrid, Editorial Gredos, 1992.
LAFFERTY, M. K. "Translating Faith from Greek to Latin: Romanitas and Christianitas in Late Fourth-Century Rome and Milan". JECS, vol. 13, $\mathrm{n}^{\circ} 1$, Johns Hopkins University Press, 2003.

LASSUS, J. The early Christian and Byzantine world. London, Hamlyn, 1967.

LAURENCE, R. e J. BERRY (eds.). Cultural Identity in the Roman Empire. Londres, Routledge, 1998.

LAWRENCE, D. L. e LOW, S. M. "The built environment and spatial form" in SIEGEL et alii. (ed.) Annual Review of Anthropology. Vol. 19, Palo Alto, Annual Reviews Inc., 1990, pp. 453-505.

LEVY, T. E. (ed.) The Archaeology of Society in the Holy Land. New York, Facts on File, 1995.

LIEU, S. N. C. e MONTSERRAT, D. (ed.) Constantine - History, historiography and legend. London and New York, Routledge, 1998.

MacDONALD, W. L. L' Architecture páleochrétienne et byzantine. Paris, Éditions des Deux-mondes, 1962.

The Architecture of the Roman Empire: vol. 2 - An Urban Appraisal. New Haven, Yale University Press, 1986.

MacMULLEN, R. Constantine. London, Weindenfeld and Nicolson, 1970.

Christianizing the Roman Empire (A.D. 100-400). New Heaven and London, Yale University Press, 1984.

MARKUS, T. Buildings and Power; Freedom and Control in the Origin of Modern Building Types. Oxford, Blackwell, 1993.

MARINS, P. C. G. Através da Rótula: Sociedade e Arquitetura no Brasil, séculos XVII a XX. São Paulo, Humanitas, 2001.

MARTIN, R. L'Urbanisme dans la Grèce Antique. Paris, Éditions A. \& J. Picard, 1956.

McGUIRE, R. e SCHIFFER, M. "A Theory of Architectural Design" in Journal of Anthropological Archaeology, vol. $2, \mathrm{n}^{\circ} 3,1983$, pp. 277-303. 
MEEKS, W. A. "Il cristianesimo" in SCHIAVONE, A. (dir.) Storia di Roma. Vol 2, L'impero mediterrâneo, tomo III: La cultura e l'impero. Parte prima: diritto, religione, filosofia, scienze nell'etá dell'impero. Torino, Giulio Einaudi editore, 1992, pp. 283-319.

MERTENS, D. Città e monumenti dei Greci d'Occidente. Roma: "L'Erma" di Bretschneider, 2006, p. 390.

MICHELIS, P. A. Esthétique de l'Art Byzantin. Paris, Flammarion Ed., 1959.

MILLAR, F. The Roman Near East 31 B.C. A.D. 337. 4. ed. Cambridge, Harvard University Press, 2001.

MOMIGLIANO, A. De Paganos, Judios y Cristianos. Mexico, Fondo de Cultura Econômica, 1992.

MONKS, G. "Architectural Symbolism and Non-verbal Communication at Upper Fort Garry" in Historical Archaeology, vol. 26, $\mathrm{n}^{\circ} 2$, 1992, pp. 37-57.

MURRAY, O. e Price, S. La cité grecque d'Homère à Alexandre. Paris, Ed. La découverte, 1992.

OLIVEIRA, W. F. A Caminho da Idade Média. Coleção Tudo é História $n^{\circ} 117$, 2. ed., São Paulo, Ed. Brasiliense, 1991.

OSTROGORSKY, G. History of the Byzantine State. Oxford, Blackwell, 1956.

OVADIAH, A.; BIRNBAUM, R. “A Greek Inscription from the Early Byzantine Church at Apollonia" IEJ. № 40, 1990.

OVADIAH, A. "Early Churches" (verbete) in STERN, E. (ed.) The New Encyclopedia of Archaeological Excavations in the Holy Land. Jerusalem, The Israel Exploration Society, 1993, pp. 305-314.

OWENS, E. J. The City in the Greek and Roman World. London, Routledge, 1996.

PALANQUE, J.-R., G. Bardy e P. de Labiolle. De la paix Constantinienne à la mort de Théodose. Série: Histoire de l'Église depuis les origines jusqu'à nos jours: 3. [Paris], Bloud \& Gray, 1950.

PANOFKSY, E. Significado nas Artes Visuais. São Paulo, Perspectiva, 1976.
Renascimento e Renascimentos na Arte

Ocidental. Lisboa, Presença, 1981.

Estudos de Iconologia. Lisboa, Estampa, 1987.

Idea: Contribuição a História do Conceito da Antiga Teoria da Arte. São Paulo, Martins Fontes, 2000.

PASTOR, J. Land and Economy in Ancient Palestine. London; New York, Routledge, 1997.

PEARSON, M. P. e RICHARDS, C. (eds.) Architecture \& Order - Approaches to Social Space. New York, Routledge, 1997.

PERRING, D. "Spatial Organization and Social Change in Roman Towns" in WALLACEHADRILL, A. e J. Rich (org.) City and Country in the Ancient World, London, Routledge, 1991, pp. 273-293.

PEVSNER, N. Dicionário Enciclopédico de Arquitetura. Rio de Janeiro, Editora Artenova S. A., 1977.

POHLSANDER, H. A. The Emperor Constantine. 2. ed. New York, Routledge, 2004.

RAPOPORT, A. House Form and Culture. Englewood Cliffs, Prentice-Hall Inc., 1969.

. Aspectos Humanos de la Forma Urbana. Barcelona, G. G., 1977.

The Meaning of Built Environment - a non-verbal Communication Approach. University of Arizona Press, 1982.

RECH, R. M. As Villae Romanas no Mediterrâneo Oriental: Estudo de uma Forma Arquitetônica na Província Judéia/Palestina. Tese de Doutorado, São Paulo, USP, 2004.

RICH, J. (ed.) The city in Late Antiquity. London, Routledge, 1996.

ROBERTSON, D. S. Arquitetura Grega e Romana. São Paulo, Martins Fontes, 1997.

ROBERTSON, M. Uma Breve História da Arte Grega. Rio de Janeiro, Zahar editores, 1982.

RODWELL, W. Church Archaeology. London, B. T. Batsford, 1989.

RUNCIMAN, S. A teocracia bizantina. Rio de Janeiro, Zahar, 1978. 
SAFRAI, Z. The Economy of Roman Palestine. London, Routledge, 1994.

SARADI-MENDELOVICI, H. "The demise of the Ancient City and the Emergence of the Mediaeval City in the Eastern Roman Empire" EMC 32. n. s. 7 (1988), pp. 365-401.

SCARRE, C. The Penguin Historical Atlas of Ancient Rome. London, Penguin Books, 1995.

SILVA, G. V. Reis, Santos e Feiticeiros - Constâncio II e os fundamentos místicos da basiléia 337-361. Vitória, Edufes, 2003.

SPERBER, D. Roman Palestine 200-400 - Money and Prices. Ramat Gan, Bar-Ilan University, 1978.

The City in Roman Palestine. New York, Oxford, 1998.

SPIESER, J. M. "La christianisation de la ville dans l'Antiquité tardive" Ktema 11, 1986, pp. 49-55.

STEDMAN, S. "Recent Research in the Archaeology of Architecture: Beyond the Foundations". JAR 4 (1). 1996, pp. 51-93.

STERN, H. L'Art Byzantin. Paris, Presses Universitaires de France, 1966.

STURGEON, M. C. "East meets west: toward a global perspective on the Roman Empire" JRA. Vol. $13 \mathrm{n}^{\circ}$ 2, Michigan, Ann Arbor, 2000.

TOMLINSON, R. From Mycenae to Constantinople - The Evolution of the Ancient City. London, Routledge, 1992.

TROMBLEY, F. R. Hellenic Religion and Christianization c. 370-529. Leiden, Brill Academic Publishers Inc., 2001.

UCKO, P. et alli. Man, settlement and urbanism. Londres, Duckworth, 1972.

WALLACE-HADRILL, A. e J. Rich (org.). City and Country in the Ancient World. London, Routledge, 1991.

WARBURG, A. The Renewal of Pagan Antiquity: Contributions to the Cultural History of the
European Renaissance. Los Angeles, The Getty Research Institute for the History of Art and the Humanities, 1999.

WARD-PERKINS, J. B. Roman Imperial Architecture. 2. ed. New Heaven; London, Yale University Press, 1981.

WACHER. J. The Coming of Rome. London, Paladin Grafton, 1986.

WEBER, M. "A dominação não-legítima (Tipologia das cidades)" Capítulo do livro Economia $e$ Sociedade. Brasília, Editora da UNIB, 2000, pp. 408-517.

WHEELER, M. El Arte y la Arquitectura de Roma. Barcelona, Ediciones Destino, 1995.

WHITTAKER, C. R. Frontiers of Roman Empire: A Social and Economic Study. London, Johns Hopkins University Press, 1997.

WHITTOW, M. "Ruling the Late Roman and Early Byzantine City: A Continuos History" Past and Present $\mathrm{n}^{\circ} 129$, Oxford, The Past and Present Society, 1990, pp. 3-29.

YEGÜL, F. K. "Memory, metaphor, and meaning in the cities of Asia Minor" JRA supl. 38, 2000, pp. 133-153.

ZANKER, P. "The city as a symbol: Rome and the creation of an urban image" JRA supl. 38, 2000 , pp. 25-41.

ZARANKIN, A. "Casa Tomada: Sistema, Poder y Vivienda Doméstica" in ZARANKIN, A. e ACUTO, F. A. (eds.) Sed non Satiata - Teoria Social en la Arqueología Latino-americana Contemporânea. Buenos Aires, Ediciones del Tridente (Colección Científica), 1999, capítulo 10, pp. 239-272.

\section{Internet}

CRANE, G. R. (ed.) Perseus Digital Library Project. Tufts University, 2006. [http://www. perseus.tufts.edu] 



imprensaoficial

Rua da Mooca, 1921 São Paulo SP

unw. imprensaoficial. com br 


\section{Universidade de São Paulo}

Reitora: Profa. Dra. Suely Vilela

Vice-Reitor: Prof. Dr. Franco Maria Lajolo

Pró-Reitoria de Cultura e Extensão Universitária

Pró-Reitor: Prof. Dr. Sedi Hirano

Pró-Reitoria de Pesquisa

Pró-Reitora: Profa. Dra. Mayana Zatz

Pró-Reitoria de Pós-Graduação

Pró-Reitor: Prof. Dr. Armando Corbani Ferraz

\section{Museu de Arqueologia e Etnologia}

Diretor: Prof. Dr. José Luiz de Morais

Vice-Diretora: Profa. Dra. Maria Cristina Oliveira Bruno

Conselho Deliberativo: Prof. Dr. José Luiz de Morais

Profa. Dra. Maria Cristina Oliveira Bruno

Profa. Dra. Myriam Krasilchik

Profa. Dra. Catarina Satie Takahashi

Prof. Dr. Eduardo Góes Neves

Profa. Dra. Fabíola Andréa Silva

Profa. Dra. Marilia Xavier Cury

Sra. Regina Estela Leopoldo e Silva

Sra. Paula Nishida Barbosa 
